\title{
32. GEOCHEMICAL AND PETROLOGIC DATA FOR BASALTS FROM SITES 756, 757, AND 758: IMPLICATIONS FOR THE ORIGIN AND EVOLUTION OF NINETYEAST RIDGE ${ }^{1}$
}

\author{
Frederick A. Frey, ${ }^{2}$ William B. Jones, ${ }^{2}$ Hugh Davies, ${ }^{3}$ and Dominique Weis ${ }^{4}$
}

\begin{abstract}
Basement lavas from Sites 756, 757, and 758 on Ninetyeast Ridge are tholeiitic basalts. Lavas from Sites 756 and 757 appear to be subaerial eruptives, but the lowermost flows from Hole $758 \mathrm{~A}$ are pillow lavas. In contrast to the compositional variation during the waning stages of Hawaiian volcanism, no alkalic lavas have been recovered from Ninetyeast Ridge and highly evolved lavas were recovered from only one of seven drill sites (DSDP Site 214). All lavas from Site 758 have relatively high $\mathrm{MgO}$ contents (8-10 $\mathrm{wt} \%$ ), and they are less evolved than lavas from Sites 756 and 757.

Although abundances of alkali metals in these Ninetyeast Ridge basalts were significantly modified by postmagmatic alteration, abundances of other elements reflect magmatic processes. At Site 757 most of the lavas are plagioclase cumulates, but lava compositions require two compositionally distinct, $\mathrm{Al}_{2} \mathrm{O}_{3}$-rich parental magmas, perhaps segregated at relatively low mantle pressures. In addition, at both Sites 756 and 758 more than one compositionally distinct parental magma is required. The compositions of these Ninetyeast Ridge lavas, especially those from Site 758, require a source component with a depleted composition; specifically, the abundance ratios $\mathrm{Th} / \mathrm{Ta}, \mathrm{Th} / \mathrm{La}, \mathrm{Ba} / \mathrm{Nb}, \mathrm{Ba} / \mathrm{La}$, and $\mathrm{La} / \mathrm{Ce}$ in these lavas are generally less than the ratios inferred for primitive mantle. Lavas from Ninetyeast Ridge and the Kerguelen Archipelago have very different chondrite-normalized REE patterns, with lower light REE/heavy REE (LREE/HREE) ratios in lavas from Ninetyeast Ridge. However, lavas from Sites 757 and 758 have Pb isotope ratios that overlap with the field defined by lavas from the Kerguelen Archipelago (Weis and Frey, this volume). Therefore, these Ninetyeast Ridge lavas contain more of a component that is relatively depleted in LREE and other highly incompatible elements, but have similar amounts of the component that controls radiogenic $\mathrm{Pb}$ isotopes.

A model involving mixing between components related to a depleted source and an enriched plume source has been proposed for the oldest Kerguelen Archipelago basalts and Ninetyeast Ridge lavas. Although the incompatible element characteristics of the Ninetyeast Ridge lavas are intermediate between depleted MORB and Kerguelen Archipelago basalts, these data are not consistent with a simple two-component mixing process. A more complex model is required.
\end{abstract}

\section{INTRODUCTION}

Ninetyeast Ridge is commonly interpreted as a volcanic chain resulting from passage of the Indian plate over a mantle hot spot, such as the Kerguelen-Heard hot spot (e.g., Duncan, 1978; Shipboard Scientific Party, 1989a), but little is known about the sources of this very large, 5000-km-long and 200-km-wide, longlived volcanic ridge and how Ninetyeast Ridge is related to other anomalous volcanic features, such as the Kerguelen Plateau and Broken Ridge, in the eastern Indian Ocean. Our research efforts focused on the basement lavas recovered from Ocean Drilling Program (ODP) Leg 121 Sites 756, 757, and 758 (Fig. 1). The ultimate objective of this research is to constrain the origin and evolution of Ninetyeast Ridge by using the geochemical and petrologic data for the lavas. In this paper we present and discuss the major and trace element compositions of 72 lavas as well as the pertinent petrography and mineral compositions. This data set is complementary to the $\mathrm{Sr}, \mathrm{Nd}$, and $\mathrm{Pb}$ isotopic data set for a subset of these samples presented by Weis and Frey (this volume). We use the compositional data to provide information about temporal variation of petrogenetic processes on several time scales; that is, ranging from processes creating compositional heterogeneity within a single flow, to processes causing compo-

${ }^{1}$ Weissel, J., Peirce, J., Taylor, E., Alt, J., et al., 1991. Proc. ODP, Sci. Results, 121: College Station, TX (Ocean Drilling Program).

${ }_{2}^{2}$ Department of Earth, Atmospheric, and Planetary Sciences, Massachusetts Institute of Technology, Cambridge, MA 02139, U.S.A.

${ }^{3}$ Geology Department, University of Papua New Guinea, Port Moresby, Papua New Guinea.

${ }^{4}$ Université Libre de Bruxelles, Brussels, Belgium. sitional variations during the waning stage of volcanic activity at each site, to processes causing intersite compositional differences.

Because we want to constrain mantle processes and sources, a hierarchy of geochemical understanding must be developed. For example, the mineralogy and bulk composition of all these lavas have been affected by postmagmatic processes in a low-temperature environment, perhaps during both submarine and subaerial alteration. It is also apparent that many of the lavas have accumulated or segregated mineral phases. Therefore, it is necessary to determine the effects of these postmelting processes before the geochemical data can be used to constrain melting processes and source compositions.

Geochemical data for these lavas from Ninetyeast Ridge can be used to evaluate several important aspects of the hot-spot hypothesis:

1. Are the compositions of lavas from Ninetyeast Ridge consistent with derivation from the Kerguelen-Heard hot spot?

2. Volcanoes formed at the Hawaiian hot spot progress through a series of well-defined growth stages (e.g., Clague and Dalrymple, 1987) that have been interpreted to reflect interactions between an ascending mantle plume, asthenosphere, and lithosphere (e.g., Feigenson, 1986; Stille et al., 1986; Frey and Roden, 1987; West et al., 1987). Are there geochemical differences among lavas from the different drill sites which provide information about the long-term, millions of years, variation of the magma sources for Ninetyeast Ridge? For example, if the lavas forming Ninetyeast Ridge have formed from the mixing of different sources, as commonly postulated for Hawaiian volcanoes, then intersite geochemical differences may document the compositional end members involved and how their proportions changed on a long time scale. 


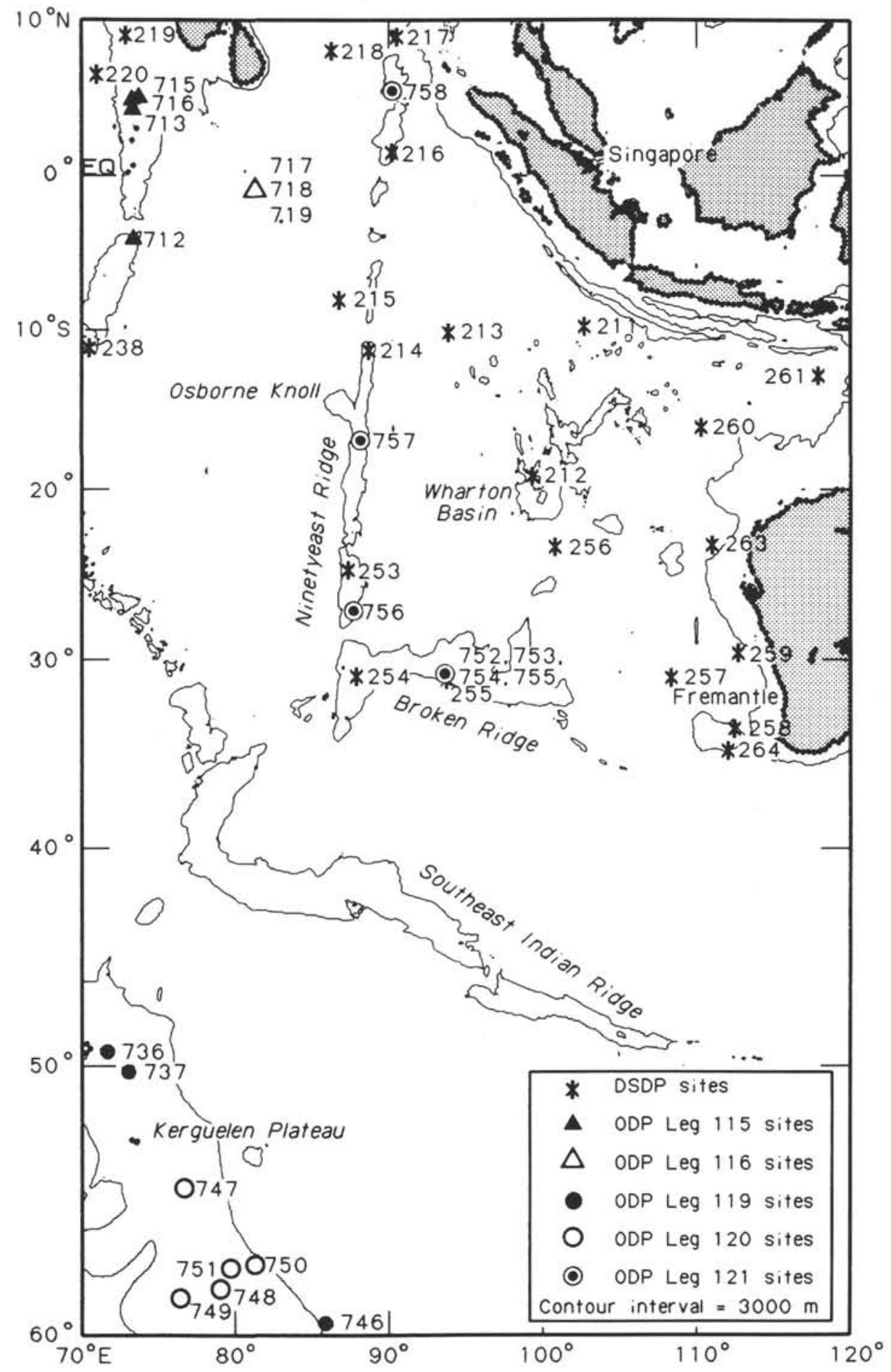

Figure 1. Location of DSDP and ODP drill sites in the eastern Indian Ocean.

3. At the Leg 121 drill sites on Ninetyeast Ridge the penetration of basaltic basement (48-178 m) was sufficient to provide information on volcanic processes during the waning volcanic activity. For example, it is well established that the surfaces of mature Hawaiian volcanoes are covered with a relatively thin veneer of alkalic lavas (e.g., the postcaldera alkalic stage of Clague, 1987). These alkalic lavas reflect a decreased energy supply as the volcano site moved away from the mantle hot spot. Specifically, this energy decrease is postulated to result in a lower degree of melting (e.g., Feigenson and Spera, 1981; Chen and
Frey, 1985) and a lower magma supply rate, which enabled extensive crystal fractionation at deep crustal levels (e.g., Frey et al., 1990). Did volcanism on Ninetyeast Ridge follow a similar pattern?

\section{ANALYTICAL METHODS}

Petrographic observations were made on approximately 120 thin sections (see Appendix A for details). Mineral compositions (see Appendix B) were determined in 50 samples using a fully automated Camebax (CAMECA) electron microprobe at the Aus- 
tralian National University-Bureau of Mineral Resources, Canberra, Australia (Ware, 1981). The accelerating voltage was 15 $\mathrm{kV}$ for silicate analyses and $25 \mathrm{kV}$ for sulfides. For most analyses beam currents were $30-60 \mathrm{nA}$, but they were lowered to $4 \mathrm{nA}$ for $\mathrm{Na}$ - and $\mathrm{K}$-bearing minerals, such as clays. Alteration minerals were identified by X-ray diffraction (XRD) using a Siemens DACO MP $\left(\mathrm{Cu}, \mathrm{K}_{\alpha}\right)$ diffractometer (J. Kamprad, Bureau of Mineral Resources).

Abundances of major elements and selected trace elements ( $\mathrm{Rb}, \mathrm{Sr}, \mathrm{Ba}, \mathrm{V}, \mathrm{Cr}, \mathrm{Ni}, \mathrm{Zn}, \mathrm{Ga}, \mathrm{Y}, \mathrm{Zr}$, and $\mathrm{Nb}$ ) were determined by X-ray fluorescence (XRF) at the University of Massachusetts (Amherst) using techniques described by Rhodes (1983). All reported data obtained by XRF are means of duplicate analyses (i.e., independent analyses of two aliquots). Abundances of $\mathrm{Na}$, $\mathrm{Sc}, \mathrm{Cr}, \mathrm{Co}, \mathrm{Cs}, \mathrm{Hf}, \mathrm{Ta}, \mathrm{Th}$, and several REE were determined at MIT by instrumental neutron activation using the approach described by Ila and Frey (1984). Determinations of $\mathrm{H}_{2} \mathrm{O}^{+}, \mathrm{H}_{2} \mathrm{O}^{-}$, and $\mathrm{CO}_{2}$ content (Hughes and Hannaker, 1978) and $\mathrm{Fe}_{2} \mathrm{O}_{3} / \mathrm{FeO}$ (Shapiro and Brannock, 1962) were done at the Bureau of Mineral Resources.

Several research groups are obtaining geochemical data for Leg 121 basalts. In order to achieve interlaboratory calibration, large volumes of six Leg 121 basalts were powdered aboard ship. Aliquots of these shipboard standards were analyzed by each group. Our results of duplicate analyses of each standard (Table 1) provide estimates of analytical precision. For major elements the average deviations from the mean for the six sets of data are $<0.5 \%$ for $\mathrm{SiO}_{2}, \mathrm{Al}_{2} \mathrm{O}_{3}, \mathrm{Fe}_{2} \mathrm{O}_{3}, \mathrm{MnO}, \mathrm{MgO}, \mathrm{CaO}$, and $\mathrm{K}_{2} \mathrm{O}$. Larger deviations occur for $\mathrm{Na}_{2} \mathrm{O}(1.4 \%)$ and $\mathrm{P}_{2} \mathrm{O}_{5}(1.7 \%) . \mathrm{Na}_{2} \mathrm{O}$ data obtained by neutron activation (NA) are more precise $(\sim 0.6 \%$ average deviation) and $\sim 5 \%$ lower than those determined by XRF. Previously, we have obtained excellent agreement between $\mathrm{Na}_{2} \mathrm{O}$ data obtained by NA at MIT and XRF at the University of Massachusetts; however, the diffraction crystal used for $\mathrm{Na}_{2} \mathrm{O}$ during the Leg 121 XRF analyses was unstable. Consequently, the $\mathrm{Na}_{2} \mathrm{O}$ data obtained by NA are more precise and accurate.

Most trace element data determined by XRF yield mean deviations of $<2 \%(\mathrm{Sr}, \mathrm{V}, \mathrm{Cr}, \mathrm{Ni}, \mathrm{Zn}, \mathrm{Y}$, and $\mathrm{Zr}$ ). Data for $\mathrm{Rb}, \mathrm{Ba}, \mathrm{Ga}$, and $\mathrm{Nb}$ are less precise. The mean deviations for $\mathrm{Ga}$ are $\sim 3 \%$ and for $\mathrm{Nb} \sim 6 \%$. However, the precision for $\mathrm{Rb}$ and $\mathrm{Ba}$ is considerably poorer. Samples with relatively high $\mathrm{Rb}$ yield precise data $(<1 \%)$, but at the levels of $0.5-2 \mathrm{ppm}$ in four of the six standard rocks the duplicate data for $\mathrm{Rb}$ vary by $\sim 20 \%-40 \%$. At the Ba levels of $\sim 20-80 \mathrm{ppm}$ in these lavas the Ba precision is $\sim 25 \%$. Most of the trace element data obtained by NA have precisions of $1 \%-3 \%$. The most imprecise NA data are for Tb $(\sim 6 \%)$, Th $(\sim 8.5 \%)$, and $\mathrm{Ta}(\sim 5.2 \%)$. These estimates of precision are consistent with the duplicate analyses of other Leg 121 samples and our previous estimates of precision (see table 1d of Frey et al., 1990). Data for U.S. Geological Survey standard basalt BHVO-1 are also given in Table 1. These data compared with recommended values enable an evaluation of accuracy.

We also evaluated contamination during sample crushing in agate and tungsten carbide containers. Crushing a rock to a fine powder always introduces contaminants, and it is necessary to know the extent of contamination resulting from different types of containers. A commonly used procedure for forming fine powders involves eccentric rotation of a container that typically contains $10-50 \mathrm{~g}$ of $0.5-1-\mathrm{cm}$ rock fragments and a puck and/or ring (e.g., the Shatterbox laboratory mill of SPEX Industries, the laboratory disc mill of Siebtechnik, the ring mill of Rock Labs). A tungsten carbide (WC) container is commonly used because WC is an efficient grinding material; however, it is established that use of a WC container introduces not only $\mathrm{W}$ and $\mathrm{C}$ but also very significant amounts of $\mathrm{Co}$ and $\mathrm{Ta}$ as well as lesser amounts of $\mathrm{Nb}$ (Joron et al., 1980; Hickson and Juras, 1986). In order to avoid $\mathrm{Co}, \mathrm{Nb}$, and $\mathrm{Ta}$ contamination, we used agate containers. Use of agate introduces $\mathrm{SiO}_{2}$ and perhaps other contaminants; a particular concern is the introduction of $\mathrm{Pb}$ and an accompanying effect on $\mathrm{Pb}$ isotopic ratios. There is also the possibility that the polishing material used for agate introduces $\mathrm{Ce}$. Because the Shatterbox aboard the ship can use WC or agate containers, and because we were concerned about contamination in our sample preparation, six Leg 121 samples were crushed separately at MIT in WC and agate containers. ${ }^{5}$ Specifically, each $\sim 25-\mathrm{cm}^{3}$ sample from the core was broken into $<0.5-\mathrm{cm}$ fragments by covering the sample with a thin plastic sheet and using a hammer. Approximately $50 \%$ of these fragments was crushed in agate and the remainder in WC. Because of the heterogeneities (e.g., very thin veins, local concentration of alteration minerals, variable phenocryst proportions) in these small samples, the two $50 \%$ aliquots are not likely to be complete compositional equivalents. Nevertheless, the contaminants introduced by each container can be identified by the systematic compositional and isotopic differences between the six sets of powders prepared in agate and WC.

A comparison of major and trace element abundances in the six pairs of samples is given in Table 2. The compositions of powders prepared in agate are included in Table 3. Although there are isolated examples of significant major element differences between powders prepared in agate and WC (e.g., $\mathrm{K}_{2} \mathrm{O}$ in two samples), the average deviation is $\leq 0.7 \%$ for most major elements with slightly larger deviations of $1 \%-1.3 \%$ for $\mathrm{MnO}, \mathrm{MgO}$, and $\mathrm{P}_{2} \mathrm{O}_{5}$ (because of low absolute abundances the precision for $\mathrm{MnO}$ and $\mathrm{P}_{2} \mathrm{O}_{5}$ is typically poorer than the precision for the other major elements). We did not detect $\mathrm{SiO}_{2}$ enrichment in the samples ground in agate. Our conclusion is that neither a WC nor an agate grinding container produces significant major element contamination.

There are, however, some very significant differences in trace element abundances. For example, powders prepared in WC are enriched by factors of $\sim 1.5-7$ in $\mathrm{Ta}$ and 1.4-2.1 in Co (Table 2). As expected for contamination caused during crushing, the significance of the contamination increases as the Ta and Co content of the rock decreases (Fig. 2); that is, the contamination is most severe in Samples 121-757C-9R-1, 105-109 cm, and 121-758A$59 \mathrm{R}-2,58-62 \mathrm{~cm}$, which contain only $\sim 0.2 \mathrm{ppm} \mathrm{Ta}$, and 121757C-9R-1, 105-109 cm, and 121-757C-12R-1, 100-104 cm, which contain only $\sim 30 \mathrm{ppm}$ Co.

Five other elements $(\mathrm{Ni}, \mathrm{Zn}, \mathrm{Nb}, \mathrm{Tb}$, and $\mathrm{Th}$ ) have mean deviations of $4.3 \%-7.3 \%$ (Table 2 ). All except Th are relatively enriched in the powder prepared in WC. The WC/agate abundance ratios are highly variable for $\mathrm{Ni}, \mathrm{Tb}$, and $\mathrm{Th}$, and there is no correlation of WC/agate abundance ratios with element abundance (Fig. 2). Consequently, for these elements the analytical uncertainty probably exceeds the contamination levels. The WC/agate abundance ratios of $\mathrm{Zn}$ and $\mathrm{Nb}$ are more uniform, (1.02-1.07 for $\mathrm{Zn}$ and 1.07-1.13 for $\mathrm{Nb}$, except one sample at 0.94 ; Table 2 and Fig. 2). Therefore, $\mathrm{Zn}$ and $\mathrm{Nb}$ were probably contaminated by $\sim 5 \%$ by crushing in WC. The results of a similar study by Joron et al. (1980) show no evidence for $\mathrm{Zn}$ contamination, but they found larger amounts $(\sim 30 \%$ increase $)$ of $\mathrm{Nb}$ contamination. Because grinding in agate produced no obvious contamination effects for major or trace elements or $\mathrm{Pb}$ isotopes (Table 2), all data reported in Table 3 are for samples crushed in agate.

The anomalously high La content of 121-758A-68R-4, 6-12 $\mathrm{cm}$, a sample ground aboard ship, apparently results from La

\footnotetext{
${ }^{5}$ Our WC container is from Spex Industries and the agate container is from Seibtechnik. The degree of contamination probably increases with the length of grinding time. Our samples were ground for $3 \mathrm{~min}$.
} 
Table 1. Duplicate analyses of Leg 121 standards.

\begin{tabular}{|c|c|c|c|c|c|c|c|c|c|c|c|c|c|}
\hline \multirow[b]{2}{*}{ XRF } & \multicolumn{2}{|c|}{$\begin{array}{c}758 \mathrm{~A}-66 \mathrm{R}-4 \\
6-12 \mathrm{~cm}\end{array}$} & \multicolumn{2}{|c|}{$\begin{array}{c}758 \mathrm{~A}-69 \mathrm{R}-1, \\
37-43 \mathrm{~cm}\end{array}$} & \multicolumn{2}{|c|}{$\begin{array}{c}757 \mathrm{C}-9 \mathrm{R}-2 \\
0-10 \mathrm{~cm}\end{array}$} & \multicolumn{2}{|c|}{$\begin{array}{l}757 \mathrm{C}-12 \mathrm{R}-1, \\
104-110 \mathrm{~cm}\end{array}$} & \multicolumn{2}{|c|}{$\begin{array}{c}756 \mathrm{D}-6 \mathrm{R}-3 \\
0-8 \mathrm{~cm}\end{array}$} & \multicolumn{2}{|c|}{$\begin{array}{c}756 \mathrm{D}-12 \mathrm{R}-2 \\
28-33 \mathrm{~cm}\end{array}$} & \multirow[t]{2}{*}{ BHVO- $1^{2}$} \\
\hline & & & & & & & & & & & & & \\
\hline $\mathrm{SiO}_{2}$ & 50.02 & 50.07 & 49.67 & 49.70 & 48.38 & 48.51 & 51.64 & 51.70 & 48.59 & 48.60 & 49.23 & 49.47 & 49.66 \\
\hline $\mathrm{TiO}_{2}$ & 1.36 & 1.37 & 1.39 & 1.38 & 0.810 & 0.817 & 0.986 & 0.942 & 2.12 & 2.13 & 2.06 & 2.09 & 2.77 \\
\hline $\mathrm{Al}_{2} \mathrm{O}_{3}$ & 14.92 & 15.08 & 15.14 & 15.21 & 22.03 & 22.03 & 18.61 & 18.81 & 15.60 & 15.63 & 14.86 & 14.89 & 13.64 \\
\hline $\mathrm{Fe}_{2} \mathrm{O}_{3}$ & 11.28 & 11.32 & 11.26 & 11.26 & 6.84 & 6.86 & 7.49 & 7.52 & 11.99 & 11.97 & 12.01 & 12.03 & 12.08 \\
\hline $\mathrm{MnO}^{3}$ & 0.207 & 0.209 & 0.180 & 0.179 & 0.085 & 0.085 & 0.167 & 0.168 & 0.181 & 0.181 & 0.154 & 0.153 & 0.179 \\
\hline $\mathrm{MgO}$ & 9.50 & 9.40 & 8.39 & 8.37 & 5.69 & 5.72 & 5.24 & 5.28 & 7.07 & 7.03 & 7.27 & 7.30 & 7.19 \\
\hline $\mathrm{CaO}$ & 10.49 & 10.47 & 11.80 & 11.72 & 13.68 & 13.68 & 12.05 & 11.95 & 10.97 & 10.98 & 10.74 & 10.79 & 11.34 \\
\hline $\mathrm{Na}_{2} \mathrm{O}$ & 2.39 & 2.35 & 2.32 & 2.25 & 2.00 & 2.01 & 2.68 & 2.65 & 2.82 & 2.69 & 2.86 & 2.83 & 2.31 \\
\hline $\mathrm{K}_{2} \mathrm{O}$ & 0.125 & 0.126 & 0.093 & 0.092 & 0.149 & 0.150 & 0.759 & 0.759 & 0.315 & 0.315 & 0.555 & 0.556 & 0.531 \\
\hline $\mathrm{P}_{2} \mathrm{O}_{5}$ & 0.094 & 0.097 & 0.100 & 0.101 & 0.063 & 0.066 & 0.077 & 0.075 & 0.175 & 0.177 & 0.169 & 0.173 & 0.274 \\
\hline Total & 100.38 & 100.49 & 100.35 & 100.27 & 99.74 & 99.94 & 99.72 & 99.86 & 99.82 & 99.69 & 99.89 & 100.28 & \\
\hline \multicolumn{14}{|c|}{ XRF Mo tube (trace elements) } \\
\hline $\mathrm{Rb}$ & 0.78 & 1.21 & 0.51 & 0.97 & 1.88 & 1.42 & 7.09 & 7.04 & 0.99 & 1.44 & 40.8 & 40.4 & 9.0 \\
\hline $\mathrm{Sr}$ & 137.2 & 135.4 & 135.1 & 134.0 & 182.4 & 180.9 & 168.0 & 168.1 & 174.6 & 176.1 & 168.8 & 168.5 & 387 \\
\hline $\mathrm{Ga}$ & 17.8 & 16.6 & 16.9 & 17.8 & 17.71 & 17.64 & 16.7 & 18.4 & 20.0 & 20.6 & 20.2 & 19.7 & 21.3 \\
\hline Y & 20.7 & 19.8 & 23.5 & 23.5 & 11.4 & 12.1 & 28.6 & 28.6 & 27.7 & 27.8 & 24.6 & 25.0 & 24.5 \\
\hline \multicolumn{14}{|c|}{ XRF Au tube (trace elements) } \\
\hline $\mathrm{Sr}$ & 138.3 & 140.4 & 136.7 & 137.6 & 189.5 & 187.7 & 172.3 & 173.6 & 181.8 & 183.9 & 173.2 & 174.5 & 403 \\
\hline $\mathrm{Ba}$ & 12.3 & 11.4 & 24.3 & 24.8 & 23.7 & 19.0 & 81.1 & 80.4 & 57.6 & 41.1 & 51.8 & 43.9 & 138 \\
\hline $\mathrm{v}$ & 303.5 & 304.3 & 290.7 & 297.7 & 172.6 & 164.8 & 193.8 & 196.9 & 314.1 & 319.9 & 288.2 & 295.6 & 284 \\
\hline${ }^{\mathrm{b}} \mathrm{Cr}$ & 240.6 & 244.3 & 164.0 & 160.9 & 175.5 & 174.0 & 97.2 & 99.8 & 257.7 & 270.3 & 196.8 & 198.9 & 289 \\
\hline $\mathrm{Ni}$ & 95.2 & 98.9 & 80.6 & 80.7 & 75.3 & 73.6 & 50.3 & 50.5 & 75.1 & 74.4 & 80.9 & 84.3 & 128 \\
\hline $\mathrm{Zn}$ & 74.2 & 75.4 & 111.8 & 113.6 & 48.2 & 53.8 & 73.4 & 73.1 & 109.2 & 110.3 & 104.5 & 104.5 & 111 \\
\hline $\mathrm{Zr}$ & 68.4 & 69.5 & 73.1 & 73.6 & 48.2 & 48.9 & 160.0 & 163.9 & 124.0 & 123.9 & 117.6 & 117.7 & 182 \\
\hline $\mathrm{Nb}$ & 3.90 & 4.22 & 4.95 & 4.82 & 3.81 & 3.12 & 10.1 & 10.6 & 9.54 & 9.03 & 8.74 & 8.78 & 18.9 \\
\hline $\mathrm{Ce}$ & 17.1 & 20.6 & 14.9 & 17.4 & 16.2 & 11.1 & 25.9 & 30.0 & 20.3 & 25.2 & 21.1 & 25.8 & 35.7 \\
\hline \multicolumn{14}{|l|}{ INAA } \\
\hline $\mathrm{Na}_{2} \mathrm{O}$ & 2.13 & 2.17 & 2.00 & 2.01 & 1.86 & 1.87 & 2.42 & 2.46 & 2.53 & 2.53 & 2.61 & 2.63 & 2.21 \\
\hline $\mathrm{La}$ & 7.20 & 7.45 & 4.10 & 4.14 & 4.03 & 4.18 & 11.2 & 11.1 & 7.77 & 8.08 & 7.18 & 7.31 & 15.5 \\
\hline $\mathrm{Ce}$ & 10.3 & 10.7 & 12.3 & 12.1 & 9.6 & 10.1 & 27.2 & 26.8 & 22.5 & 21.9 & 22.0 & 21.5 & 39.5 \\
\hline $\mathrm{Nd}$ & 7.66 & 7.63 & 8.2 & 7.4 & 5.7 & 5.5 & 14.1 & 13.9 & 13.9 & 13.0 & 12.8 & 12.8 & 24.2 \\
\hline Sm & 2.37 & 2.29 & 2.56 & 2.48 & 1.58 & 1.55 & 3.75 & 3.64 & 3.82 & 3.82 & 3.77 & 3.75 & 5.93 \\
\hline Eu & 0.95 & 0.91 & 0.95 & 0.94 & 0.65 & 0.63 & 1.11 & 1.13 & 1.45 & 1.42 & 1.39 & 1.38 & 2.12 \\
\hline $\mathrm{Tb}$ & 0.47 & 0.59 & 0.55 & 0.55 & 0.34 & 0.34 & 0.75 & 0.65 & 0.70 & 0.72 & 0.76 & 0.68 & 0.91 \\
\hline $\mathrm{Yb}$ & 2.13 & 2.12 & 2.31 & 2.23 & 1.09 & 1.22 & 2.84 & 2.85 & 2.45 & 2.52 & 2.21 & 2.35 & 1.96 \\
\hline Lu & 0.32 & 0.33 & 0.35 & 0.36 & 0.22 & 0.20 & 0.43 & 0.46 & 0.37 & 0.36 & 0.36 & 0.34 & 0.28 \\
\hline $\mathrm{Hf}$ & 1.73 & 1.71 & 1.87 & 1.76 & 1.07 & 1.07 & 3.51 & 3.51 & 2.88 & 2.74 & 2.80 & 2.80 & 4.37 \\
\hline Th & - & - & 0.45 & 0.30 & 0.31 & 0.27 & 1.62 & 1.64 & 0.67 & 0.74 & 0.61 & 0.64 & 0.95 \\
\hline Ta & 0.29 & 0.29 & 0.32 & 0.27 & 0.24 & 0.22 & 0.54 & 0.54 & 0.55 & 0.60 & 0.63 & 0.57 & 1.13 \\
\hline $\mathrm{Sc}$ & 47.7 & 47.6 & 44.3 & 44.8 & 25.8 & 26.0 & 28.4 & 28.5 & 40.3 & 40.5 & 43.6 & 43.2 & 31.8 \\
\hline${ }^{b} \mathrm{Cr}$ & 328 & 337 & 251 & 262 & 170 & 175 & 97 & 95 & 251 & 257 & 199 & 200 & 289 \\
\hline Co & 48.6 & 48.2 & 46.6 & 46.5 & 29.1 & 29.1 & 29.7 & 30.0 & 46.1 & 46.6 & 46.7 & 46.9 & 45.1 \\
\hline Cs & - & - & - & - & - & - & - & - & - & - & 0.99 & 1.18 & - \\
\hline
\end{tabular}

Note: Major element data on an oxidized and anhydrous basis from XRF analysis. Trace element data are means of duplicate analyses of separate aliquots. All trace element data determined by XRF and INAA (including $\mathrm{Na}_{2} \mathrm{O}$ ) are on an as-received basis.

${ }^{a}$ The USGS standard was analyzed several times concurrently with the Leg 121 samples. Reported data are averages.

${ }^{b} \mathrm{Cr}$ was determined by XRF and INAA. Data for Sites 757C and 756D are in good agreement. However, for both samples from Hole 758A the XRF Cr value is $\sim 100 \mathrm{ppm}$ higher. This discrepancy is unexplained, but we suspect the error is in the XRF analysis. Ce values determined by XRF and INAA are in general agreement, but the INAA values are much more precise.

contamination during sample processing (Table 3 ). $\mathrm{La}_{2} \mathrm{O}_{3}$ is used as a heavy absorber in the flux used in making glasses for major element analysis by XRF. Another sample, 121-758A-66R-4, $29-33 \mathrm{~cm}$, from the same flow unit is compositionally very similar to $121-758 \mathrm{~A}-68 \mathrm{R}-4,6-12 \mathrm{~cm}$, but it has $(\mathrm{La} / \mathrm{Ce})_{\mathrm{N}}<1$, similar to that of other samples from Hole 758A (Table 3). Therefore, the high $\mathrm{La}$ value in Sample $66 \mathrm{R}-4,29-33 \mathrm{~cm}$, is omitted from subsequent discussion.

\section{RESULTS}

Postmagmatic alteration has affected all of the samples. Alteration minerals are abundant in thin section (see Appendix A), and geochemical indices of alteration such as $\mathrm{CO}_{2}, \mathrm{H}_{2} \mathrm{O}^{+}$, and $\mathrm{H}_{2} \mathrm{O}^{-}$contents and $\mathrm{Fe}_{2} \mathrm{O}_{3} / \mathrm{FeO}$ are high and well above typical magmatic values (Table 3 ). Specifically, $\mathrm{CO}_{2}$ contents range from $0.13 \%$ to $1.99 \%$ in all of the lavas. Lavas from Holes $756 \mathrm{D}, 757 \mathrm{C}$, 
Table 2. Comparison of aliquots crushed in tungsten carbide (WC) and agate. Values indicate the abundance ratio, WC aliquot/agate vs. aliquot.

\begin{tabular}{|c|c|c|c|c|c|c|c|c|c|}
\hline & $\begin{array}{c}756 \mathrm{C}-10 \mathrm{~N}-1 \\
32-36 \mathrm{~cm}\end{array}$ & \multicolumn{2}{|c|}{$\begin{array}{c}756 \mathrm{D}-4 \mathrm{R}-1 \text {, } \\
35-39 \mathrm{~cm}\end{array}$} & $\begin{array}{l}757 \mathrm{C}-9 \mathrm{R}-1 \\
105-109 \mathrm{~cm}\end{array}$ & \multicolumn{2}{|c|}{$\begin{array}{l}757 \mathrm{C}-12 \mathrm{R}-1 \\
100-104 \mathrm{~cm}\end{array}$} & $\begin{array}{c}758 \mathrm{~A}-58 \mathrm{R}-6 \\
21-25 \mathrm{~cm}\end{array}$ & $\begin{array}{c}758 \mathrm{~A}-59 \mathrm{R}-2 \\
58-62 \mathrm{~cm}\end{array}$ & $\begin{array}{c}\text { Average } \\
\text { deviation }(\%)\end{array}$ \\
\hline $\mathrm{SiO}_{2}$ & 1.00 & \multicolumn{2}{|c|}{1.01} & 0.99 & \multicolumn{2}{|c|}{1.01} & 1.00 & 1.00 & +0.2 \\
\hline $\mathrm{TiO}_{2}$ & 1.01 & \multicolumn{2}{|c|}{0.98} & 1.04 & \multicolumn{2}{|c|}{1.02} & 0.99 & 0.99 & +0.5 \\
\hline $\mathrm{Al}_{2} \mathrm{O}_{3}$ & 1.00 & \multicolumn{2}{|c|}{1.00} & 0.97 & \multicolumn{2}{|c|}{0.98} & 1.01 & 1.00 & -0.7 \\
\hline $\mathrm{Fe}_{2} \mathrm{O}_{3}$ & 1.00 & \multicolumn{2}{|c|}{0.97} & 1.04 & \multicolumn{2}{|c|}{1.03} & 0.99 & 1.00 & +0.5 \\
\hline $\mathrm{MnO}$ & 1.00 & \multicolumn{2}{|c|}{0.97} & 1.05 & \multicolumn{2}{|c|}{1.05} & 1.00 & 0.99 & +1.0 \\
\hline $\mathrm{MgO}$ & 1.00 & \multicolumn{2}{|c|}{1.03} & 1.03 & \multicolumn{2}{|c|}{1.03} & 0.99 & 1.00 & +1.3 \\
\hline $\mathrm{CaO}$ & 1.00 & \multicolumn{2}{|c|}{1.03} & 0.98 & \multicolumn{2}{|c|}{0.99} & 1.02 & 1.00 & +0.3 \\
\hline${ }^{\mathrm{a}} \mathrm{Na}_{2} \mathrm{O}$ & 1.04 & \multicolumn{2}{|c|}{0.98} & 1.02 & \multicolumn{2}{|c|}{0.97} & 0.98 & 0.97 & -0.7 \\
\hline $\mathrm{K}_{2} \mathrm{O}$ & 1.00 & \multicolumn{2}{|c|}{0.88} & 1.10 & \multicolumn{2}{|c|}{1.03} & 1.00 & 1.00 & +0.2 \\
\hline $\mathrm{P}_{2} \mathrm{O}_{5}$ & 1.00 & \multicolumn{2}{|c|}{1.00} & 1.05 & \multicolumn{2}{|c|}{1.00} & 0.99 & 1.02 & +1.0 \\
\hline${ }^{\mathrm{b}} \mathrm{Na}_{2} \mathrm{O}$ & 1.02 & \multicolumn{2}{|c|}{0.98} & 1.00 & \multicolumn{2}{|c|}{1.01} & 1.01 & 1.00 & +0.3 \\
\hline $\mathrm{Rb}$ & 1.17 & & & 1.29 & & & 0.85 & 0.77 & -1.2 \\
\hline $\mathrm{Sr}$ & 0.98 & & & 0.98 & & & 1.01 & 0.99 & -1.0 \\
\hline $\mathrm{Ba}$ & 1.08 & & & 0.47 & & & 1.21 & 0.82 & -3.8 \\
\hline $\mathrm{Sc}$ & 0.99 & & & 1.04 & & & 1.01 & 1.01 & +1.3 \\
\hline v & 1.00 & & & 1.02 & & & 1.01 & 1.01 & +0.3 \\
\hline $\mathrm{Cr}$ & 1.00 & & & 1.05 & & & - & 0.99 & +2.4 \\
\hline Co & 1.63 & & & 2.08 & & & 1.40 & 1.34 & $c+58.5$ \\
\hline $\mathrm{Ni}$ & 1.01 & & & 1.08 & & & 1.18 & 1.15 & $c+7.3$ \\
\hline $\mathrm{Zn}$ & 1.02 & & & 1.07 & & & 1.04 & 1.05 & $c+5.3$ \\
\hline $\mathrm{Ga}$ & 0.96 & & & 0.93 & & & 1.00 & 1.05 & -1.7 \\
\hline $\mathrm{Zr}$ & 1.00 & & & 1.06 & & & 1.00 & 1.03 & +1.2 \\
\hline $\mathrm{Y}$ & 1.00 & & & 0.97 & & & 0.99 & 1.01 & -0.8 \\
\hline $\mathrm{Nb}$ & 1.09 & & & 1.08 & & & 1.07 & 1.08 & $c, d+6.5(+9.0)$ \\
\hline $\mathrm{Hf}$ & 1.05 & & & 1.07 & & & 1.07 & 0.95 & +2.7 \\
\hline $\mathrm{Ta}$ & 1.87 & & & 6.78 & & & 1.60 & 3.78 & $c^{c}+198$ \\
\hline Th & 0.76 & & & 1.12 & & & 0.81 & 0.90 & -4.8 \\
\hline $\mathrm{La}$ & 0.98 & & & 1.04 & & & 0.99 & 1.00 & +1.7 \\
\hline $\mathrm{Ce}$ & 0.99 & & & 1.06 & & & 1.00 & 1.05 & +3.0 \\
\hline $\mathrm{Nd}$ & 0.96 & & & 0.98 & & & 0.89 & 1.03 & -1.3 \\
\hline $\mathrm{Sm}$ & 1.02 & & & 1.05 & & & 1.02 & 1.01 & +3.5 \\
\hline $\mathrm{Eu}$ & 0.98 & & & 1.05 & & & 0.98 & 0.97 & +0.8 \\
\hline $\mathrm{Tb}$ & 1.04 & & & 1.12 & & & 0.97 & 1.06 & +4.3 \\
\hline $\mathrm{Yb}$ & 1.01 & & & 1.01 & & & 1.00 & 0.96 & +0.7 \\
\hline Lu & 1.00 & & & 1.00 & & & 0.99 & 1.05 & +1.3 \\
\hline & & Agate & WC & & Agate & wC & & & \\
\hline${ }^{206} \mathrm{~Pb} /{ }^{2}$ & ${ }^{4} \mathrm{~Pb}$ & $\overline{18.92}$ & $\overline{18.94}$ & & $\overline{18.78}$ & $\overline{18.85}$ & & & \\
\hline${ }^{207} \mathrm{~Pb} /{ }^{2}$ & ${ }^{4} \mathrm{~Pb}$ & $\begin{array}{l}15.72 \\
15.64\end{array}$ & 15.61 & & 15.61 & 15.63 & & & \\
\hline${ }^{208} \mathrm{~Pb} /{ }^{2}$ & ${ }^{4} \mathrm{~Pb}$ & 39.07 & 39.03 & & 39.05 & 38.99 & & & \\
\hline
\end{tabular}

Notes: The first $\mathrm{Na}_{2} \mathrm{O}$ is for XRF data; the second $\mathrm{Na}_{2} \mathrm{O}$ is for NA data.

a XRF data.

b NA data.

${ }^{\mathrm{c}}$ Elements enriched in the WC crush by more than $5 \%$.

d Value in parentheses is without data for Sample 121-756D-4R-1, 35-39 cm.

and $758 \mathrm{~A}$ range in percent $\mathrm{H}_{2} \mathrm{O}^{+}$content from 0.71 to $2.08,1.01$ to 7.25 , and 0.99 to 2.12 , respectively, and $\mathrm{Fe}_{2} \mathrm{O}_{3} / \mathrm{FeO}$ ranges from 0.41 to $2.79,0.51$ to 4.98 , and 0.84 to 1.61 , respectively. The highest $\mathrm{H}_{2} \mathrm{O}^{+}$contents and $\mathrm{Fe}_{2} \mathrm{O}_{3} / \mathrm{FeO}$ are in lavas from Hole $757 \mathrm{C}$, and the highest $\mathrm{H}_{2} \mathrm{O}^{-}$occurs in lavas from Site 758 (Fig. 3 ). Based on weight loss during acid leaching (Weis and Frey, this volume), the youngest lavas (i.e., samples from Site 756, see ${ }^{40} \mathrm{Ar} /{ }^{39} \mathrm{Ar}$ dating by Duncan, this volume) are the least altered.

As discussed in detail later, there is abundant evidence for $\mathrm{K}_{2} \mathrm{O}$ and $\mathrm{Rb}$ mobility during postmagmatic alteration processes; for example, many Hole $757 \mathrm{C}$ samples with high $\mathrm{H}_{2} \mathrm{O}^{+}$have $\mathrm{K}_{2} \mathrm{O} / \mathrm{P}_{2} \mathrm{O}_{5}$ ratios well above 2 (Fig. 3), whereas most unaltered oceanic basalts have $\mathrm{K}_{2} \mathrm{O} / \mathrm{P}_{2} \mathrm{O}_{5}$ ratios between 1 and 2 . Because of this $\mathrm{K}_{2} \mathrm{O}$ mobility, neither CIPW normative proportions nor the IUGS classification for basalts (LeBas et al., 1986) was used. An example of the problems arising from alkali mobility during alteration is that on a $\mathrm{Na}_{2} \mathrm{O}+\mathrm{K}_{2} \mathrm{O}$ vs. $\mathrm{SiO}_{2}$ content plot (Fig. 4) all of the Hole 758A and most of the Hole 756D lavas are in the tholeiitic field. However, five samples from Hole $757 \mathrm{C}(9 \mathrm{R}-5$, $70-73 \mathrm{~cm}, 10 \mathrm{R}-2,66-70 \mathrm{~cm}, 10 \mathrm{R}-3,2-6 \mathrm{~cm}, 11 \mathrm{R}-2,51-56 \mathrm{~cm}$, and $12 \mathrm{R}-4,24-29 \mathrm{~cm}$ ) contain more than $6 \% \mathrm{Na}_{2} \mathrm{O}+\mathrm{K}_{2} \mathrm{O}$ and are in the alkalic basalt field. As discussed later, these anomalously high $\mathrm{Na}_{2} \mathrm{O}$ contents result from late-stage alteration and these samples are altered tholeiitic basalts. The remarkably uniform $\mathrm{SiO}_{2}$ contents of the Leg 121 basalts, ranging from $47.2 \%$ to $51.8 \%$ on an anhydrous and oxidized basis (Table 3 and Fig. 4), overlap with the range of tholeiitic basalts. Although at each site the basalts do not define trends of increasing $\mathrm{FeO}^{*} / \mathrm{MgO}$ and $\mathrm{SiO}_{2}$, the Leg 121 lavas lie dominantly within the tholeiitic field on this classification plot (Fig. 4). Perhaps the most direct approach for inferring melt compositions is from the analyses of unaltered phenocrysts. The compositions of clinopyroxenes from each of the sites are typical of clinopyroxene in tholeiitic and transitional basalts (Fig. 5).

In the following sections the important geochemical characteristics of lavas from each drill site are identified with the aim of distinguishing compositional features that reflect dominantly postmagmatic alteration processes from those that reflect dominantly magmatic processes and source characteristics. An important feature of the data set is that lavas at each site have a distinctive set of geochemical characteristics; for example, in Figures 6 and 7 there is little overlap among lavas from the three 
Table 3. Composition of lavas, Leg 121.

\begin{tabular}{|c|c|c|c|c|c|c|c|c|c|c|c|c|c|c|}
\hline $\begin{array}{l}\text { Sample } \\
\text { Flow unit }\end{array}$ & $\begin{array}{c}756 \mathrm{C}- \\
10 \mathrm{~N}-1 \\
32-36 \mathrm{~cm} \\
756 \mathrm{C}-\mathrm{F} 1\end{array}$ & $\begin{array}{c}756 \mathrm{D}- \\
4 \mathrm{R}-1 \\
35-39 \mathrm{~cm} \\
756 \mathrm{D}-\mathrm{F} 1\end{array}$ & $\begin{array}{c}756 \mathrm{D}- \\
4 \mathrm{R}-1 \\
85-89 \mathrm{~cm} \\
756 \mathrm{D}-\mathrm{F} 2\end{array}$ & $\begin{array}{c}756 \mathrm{D}- \\
6 \mathrm{R}-1 \\
6-10 \mathrm{~cm} \\
756 \mathrm{D}-\mathrm{F} 4\end{array}$ & $\begin{array}{c}\text { 756D- } \\
\text { 6R-2. } \\
9-13 \mathrm{~cm} \\
756 \mathrm{D}-5(\mathrm{br})\end{array}$ & $\begin{array}{c}756 \mathrm{D}- \\
6 \mathrm{R}-2, \\
13-17 \mathrm{~cm} \\
756 \mathrm{D}-5(\mathrm{bl})\end{array}$ & $\begin{array}{c}756 \mathrm{D}- \\
6 \mathrm{R}-3, \\
0-8 \mathrm{~cm} \\
756 \mathrm{D}-\mathrm{F} 5\end{array}$ & $\begin{array}{c}\text { 756D- } \\
\text { 7R-1. } \\
100-104 \mathrm{~cm} \\
756 \mathrm{D}-\mathrm{F} 6\end{array}$ & $\begin{array}{c}756 \mathrm{D}- \\
7 \mathrm{R}-3, \\
54-58 \mathrm{~cm} \\
756 \mathrm{D}-\mathrm{F} 6\end{array}$ & $\begin{array}{c}756 \mathrm{D}- \\
8 \mathrm{R}-1 \\
20-23 \mathrm{~cm} \\
756 \mathrm{D}-\mathrm{F} 7\end{array}$ & $\begin{array}{c}756 \mathrm{D}- \\
9 \mathrm{R}-2, \\
21-24 \mathrm{~cm} \\
756 \mathrm{D}-\mathrm{F9}\end{array}$ & $\begin{array}{c}756 \mathrm{D}- \\
10 \mathrm{R}-1, \\
99-103 \mathrm{~cm} \\
756 \mathrm{D}-\mathrm{F} 12\end{array}$ & $\begin{array}{c}756 \mathrm{D}- \\
\text { 10R-3, } \\
58-62 \mathrm{~cm} \\
756 \mathrm{D}-\mathrm{F} 12\end{array}$ & $\begin{array}{c}756 \mathrm{D}- \\
11 \mathrm{R}-1, \\
102-106 \mathrm{~cm} \\
756 \mathrm{D}-\mathrm{F} 13\end{array}$ \\
\hline $\mathrm{SiO}_{2}$ & 49.24 & 47.68 & 47.94 & 48.60 & 49.05 & 48.57 & 48.59 & 49.22 & 48.36 & 49.44 & 49.03 & 49.93 & 48.95 & 49.23 \\
\hline $\mathrm{TiO}_{2}$ & 2.46 & 2.68 & 2.64 & 2.84 & 2.18 & 2.17 & 2.12 & 2.47 & 2.22 & 2.11 & 2.01 & 2.14 & 2.01 & 1.96 \\
\hline $\mathrm{Al}_{2} \mathrm{O}_{3}$ & 14.75 & 15.51 & 14.72 & 15.33 & 15.32 & 15.50 & 15.61 & 15.99 & 14.56 & 15.47 & 14.67 & 15.28 & 14.50 & 15.43 \\
\hline $\mathrm{Fe}_{2} \mathrm{O}_{3}$ & 12.55 & 14.58 & 14.97 & 14.35 & 12.40 & 12.31 & 11.98 & 11.03 & 12.82 & 12.51 & 12.40 & 11.57 & 12.32 & 11.96 \\
\hline $\mathrm{MnO}$ & 0.20 & 0.18 & 0.19 & 0.13 & 0.16 & 0.18 & 0.18 & 0.12 & 0.17 & 0.12 & 0.17 & 0.14 & 0.18 & 0.14 \\
\hline $\mathrm{MgO}$ & 6.28 & 4.89 & 5.53 & 5.30 & 6.80 & 6.92 & 7.05 & 6.43 & 7.17 & 6.69 & 7.57 & 6.71 & 7.50 & 6.90 \\
\hline $\mathrm{CaO}$ & 10.99 & 10.17 & 10.30 & 9.54 & 10.64 & 11.10 & 10.98 & 10.50 & 10.74 & 10.33 & 11.13 & 10.76 & 11.42 & 10.95 \\
\hline $\mathrm{Na}_{2} \mathrm{O}$ & 2.79 & 3.10 & 2.80 & 2.82 & 2.73 & 2.87 & 2.75 & 3.75 & 2.93 & 2.54 & 2.48 & 2.65 & 2.91 & 2.67 \\
\hline $\mathrm{K}_{2} \mathrm{O}$ & 0.49 & 0.91 & 0.510 & 0.643 & 0.489 & 0.227 & 0.32 & 0.412 & 0.638 & 0.531 & 0.208 & 0.517 & 0.212 & 0.452 \\
\hline $\mathrm{P}_{2} \mathrm{O}_{5}$ & 0.23 & 0.22 & 0.235 & 0.267 & 0.177 & 0.178 & 0.176 & 0.220 & 0.189 & 0.208 & 0.163 & 0.172 & 0.163 & 0.152 \\
\hline Sum & 99.98 & 99.92 & 99.84 & 99.81 & 99.95 & 100.01 & 99.76 & 100.14 & 99.80 & 99.94 & 99.83 & 99.87 & 100.17 & 99.85 \\
\hline $\mathrm{H}_{2} \mathrm{O}^{+}$ & 0.71 & 0.97 & 1.18 & 1.87 & 1.55 & 1.50 & 1.02 & 0.97 & 1.43 & 2.08 & 1.47 & 1.60 & 1.13 & 1.72 \\
\hline $\mathrm{H}_{2} \mathrm{O}^{-}$ & 0.79 & 0.51 & 0.72 & 1.17 & 0.81 & 0.57 & 0.75 & 1.46 & 0.79 & 1.92 & 0.67 & 1.08 & 0.55 & 1.16 \\
\hline $\mathrm{CO}_{2}$ & 0.15 & 0.17 & 0.30 & 0.13 & 0.32 & 0.38 & 0.41 & 0.20 & 0.54 & 0.12 & 0.13 & 0.42 & 0.24 & 0.29 \\
\hline $\mathrm{Fe}_{2} \mathrm{O}_{3} / \mathrm{FeO}$ & 0.91 & 2.79 & 2.23 & 1.74 & 1.24 & 0.51 & 0.46 & 1.84 & 1.36 & 2.90 & 0.55 & 1.28 & 0.41 & 1.79 \\
\hline $\mathrm{Na}_{2} \mathrm{O}$ (NA) & $2.54 \pm 0.01$ & $2.84 \pm 0.06$ & 2.69 & 2.52 & $2.56 \pm 0.03$ & $2.60 \pm 0.01$ & $2.53 \pm 0.01$ & 3.02 & 2.59 & $2.25 \pm 0.07$ & 2.35 & 2.40 & $2.42 \pm 0.01$ & 2.36 \\
\hline & 6.5 & 10.0 & 15 & 19 & 33 & 1.1 & 1.2 & 2.9 & 70 & 13 & 1.3 & 16 & 1.4 & 16 \\
\hline Cs & & & 0.71 & 1.0 & $1.6 \pm 0.1$ & - & - & - & 2.1 & $0.3 \pm 0.1$ & - & 0.38 & - & 0.58 \\
\hline $\mathrm{Sr}$ & 188 & 195 & 181 & 166 & 171 & 174 & 175 & 200 & 171 & 153 & 163 & 156 & 168 & 156 \\
\hline $\mathrm{Ba}$ & 70 & 69 & 46 & 58 & 33 & 44 & 49 & 56 & 5i & 47 & 44 & 31 & 47 & - \\
\hline Sc & $42.2 \pm 0.9$ & $46.9 \pm 1.3$ & 46.9 & 44.6 & $40.8 \pm 0.2$ & $41.9 \pm 0.1$ & $40.4 \pm 0.1$ & 44.2 & 40.2 & $40.9 \pm 0.7$ & 42.4 & 44.0 & $43.0 \pm 0.3$ & 42.4 \\
\hline $\mathrm{v}$ & 357 & 420 & 393 & 351 & 310 & 325 & 317 & 352 & 312 & 286 & 297 & 302 & 308 & 291 \\
\hline $\mathrm{Cr}$ & $197 \pm 4$ & $139 \pm 2$ & 156 & 192 & $256 \pm 2$ & $266 \pm 3$ & $254 \pm 4$ & 239 & 220 & $279 \pm 6$ & 255 & 263 & $258 \pm 1$ & 267 \\
\hline Co & $53.0 \pm 1.1$ & $59.6 \pm 1.8$ & 58.7 & 45.7 & $43.5 \pm 0.3$ & $47.2 \pm 0.1$ & $46.4 \pm 0.4$ & 48.6 & 46.7 & $44.2 \pm 0.5$ & 47.2 & 44.9 & $47.4 \pm 0.1$ & 44.5 \\
\hline $\mathrm{Ni}$ & 85 & 76 & 76 & 87 & 74 & 75 & 75 & 85 & 86 & 104 & 86 & 84 & 86 & 90 \\
\hline $\mathrm{Zn}$ & 124 & 110 & 140 & 134 & 105 & 111 & 110 & 122 & 109 & 114 & 112 & 106 & 112 & 101 \\
\hline $\mathrm{Ga}$ & 22 & 22 & 21 & 21 & 20 & 20 & 20 & 21 & 20 & 18 & 19 & 20 & 19 & 19 \\
\hline $\mathrm{Y}$ & 31.5 & 33.9 & 30.9 & 31.8 & 27.1 & 29.4 & 27.8 & 27.4 & 28.7 & 25.9 & 27.0 & 26.0 & 27.2 & 25.6 \\
\hline $\mathrm{Zr}$ & 156 & 177 & 166 & 171 & 123 & 125 & 124 & 157 & 135 & 126 & 113 & 119 & 115 & 110 \\
\hline $\mathrm{Nb}$ & 11.7 & 13.5 & 12.6 & 13.6 & 9.4 & 9.7 & 9.3 & 12.6 & 10.7 & 12.0 & 8.2 & 9.3 & 8.8 & 8.7 \\
\hline $\mathrm{Hf}$ & $3.69 \pm 0.03$ & $4.18 \pm 0.09$ & 4.08 & 4.23 & $2.98 \pm 0.01$ & $3.12 \pm 0.04$ & $2.81 \pm 0.10$ & 3.83 & 3.50 & $2.98 \pm 0.11$ & 2.51 & 2.96 & $2.90 \pm 0.10$ & 2.46 \\
\hline $\mathrm{Ta}$ & $0.76 \pm 0.04$ & $0.82 \pm 0.03$ & 0.82 & 0.86 & $0.62 \pm 0.04$ & $0.64 \pm 0.04$ & $0.58 \pm 0.004$ & 0.75 & 0.58 & $0.75 \pm 0.18$ & 0.60 & 0.61 & $0.54 \pm 0.02$ & 0.53 \\
\hline Th & $1.14 \pm 0.16$ & $1.14 \pm 0.04$ & 1.33 & 1.70 & $0.71 \pm 0.08$ & $0.70 \pm 0.03$ & $0.70 \pm 0.05$ & 1.01 & 0.81 & $0.75 \pm 0.04$ & 0.67 & 0.66 & $0.64 \pm 0.01$ & 0.65 \\
\hline $\mathrm{La}$ & $9.56 \pm 0.18$ & $9.46 \pm 0.05$ & 8.96 & 10.8 & $7.72 \pm 0.40$ & $8.20 \pm 0.01$ & $7.92 \pm 0.22$ & 9.78 & 8.97 & $8.99 \pm 0.08$ & 7.36 & 7.42 & $7.42 \pm 0.01$ & 6.89 \\
\hline $\mathrm{Ce}$ & $26.0 \pm 0.5$ & $26.0 \pm 0.2$ & 26.5 & 30.1 & $22.1 \pm 1.1$ & $23.4 \pm 0.3$ & $22.2 \pm 0.4$ & 27.6 & 23.9 & $24.3 \pm 0.4$ & 20.6 & 20.7 & $20.0 \pm 0.4$ & 17.7 \\
\hline $\mathrm{Nd}$ & $17.2 \pm 0.1$ & $16.9 \pm 0.7$ & 16.8 & 18.7 & $12.9 \pm 0.1$ & $14.0 \pm 0.9$ & $13.4 \pm 0.6$ & 16.8 & 14.2 & $14.5 \pm 0.1$ & 13.1 & 13.5 & $13.0 \pm 0.1$ & 11.9 \\
\hline $\mathrm{Sm}$ & $4.66 \pm 0.09$ & $4.81 \pm 0.04$ & 5.14 & 5.40 & $3.97 \pm 0.18$ & $4.18 \pm 0.14$ & $3.82 \pm 0.01$ & 4.67 & 4.32 & $3.93 \pm 0.03$ & 3.80 & 3.89 & $3.82 \pm 0.06$ & 3.71 \\
\hline Eu & $1.72 \pm 0.6$ & $1.68 \pm 0.01$ & 1.83 & 1.92 & $1.46 \pm 0.01$ & $1.54 \pm 0.01$ & $1.44 \pm 0.02$ & 1.70 & 1.59 & $1.36 \pm 0.05$ & 1.44 & 1.36 & $1.40 \pm 0.04$ & 1.37 \\
\hline $\mathrm{Tb}$ & $0.90 \pm 0.01$ & $0.85 \pm 0.01$ & 0.97 & 1.05 & $0.79 \pm 0.01$ & $0.78 \pm 0.06$ & $0.71 \pm 0.01$ & 0.86 & 0.87 & $0.73 \pm 0.01$ & 0.74 & 0.78 & $0.82 \pm 0.07$ & 0.81 \\
\hline $\mathrm{Yb}$ & $2.80 \pm 0.09$ & $3.21 \pm 0.64$ & 3.00 & 3.10 & $2.42 \pm 0.01$ & $2.72 \pm 0.01$ & $2.49 \pm 0.05$ & 2.77 & 2.68 & $2.34 \pm 0.01$ & 2.45 & 2.40 & $2.60 \pm 0.01$ & 2.36 \\
\hline Lu & $0.39 \pm 0.02$ & $0.48 \pm 0.64$ & 0.46 & 0.46 & $0.37 \pm 0.01$ & $0.42 \pm 0.01$ & $0.37 \pm 0.01$ & 0.44 & 0.44 & $0.38 \pm 0.01$ & 0.39 & 0.34 & $0.39 \pm 0.01$ & 0.36 \\
\hline
\end{tabular}

Note: All data for trace elements and $\mathrm{Na}_{2} \mathrm{O}$ obtained by neutron activation (NA) are on an "as-received" basis. Dash indicates abundance below detection limit. 
Table 3 (continued).

\begin{tabular}{|c|c|c|c|c|c|c|c|c|c|c|c|c|c|c|c|}
\hline $\begin{array}{l}\text { Sample } \\
\text { Flow unit }\end{array}$ & $\begin{array}{c}756 \mathrm{D}- \\
12 \mathrm{R}-2, \\
28-33 \mathrm{~cm} \\
756 \mathrm{D}-\mathrm{F} 14\end{array}$ & $\begin{array}{c}\text { 756D } \\
12 \mathrm{R}-3, \\
139-143 \mathrm{~cm} \\
756 \mathrm{D}-\mathrm{F} 14\end{array}$ & $\begin{array}{c}757 \mathrm{C}- \\
9 \mathrm{R}-1, \\
105-109 \mathrm{~cm} \\
757 \mathrm{C}-\mathrm{F} 2\end{array}$ & $\begin{array}{c}757 \mathrm{C}- \\
9 \mathrm{R}-2, \\
0-10 \mathrm{~cm} \\
757 \mathrm{C}-\mathrm{F} 2\end{array}$ & $\begin{array}{c}757 \mathrm{C}- \\
9 \mathrm{R}-3, \\
6-10 \mathrm{~cm} \\
757 \mathrm{C}-\mathrm{F} 2\end{array}$ & $\begin{array}{c}757 \mathrm{C}- \\
9 \mathrm{R} 4, \\
38-42 \mathrm{~cm} \\
757 \mathrm{C}-\mathrm{F} 3\end{array}$ & $\begin{array}{c}757 \mathrm{C}- \\
9 \mathrm{R}-5, \\
34-38 \mathrm{~cm} \\
757 \mathrm{C}-\mathrm{F} 4\end{array}$ & $\begin{array}{c}757 \mathrm{C}- \\
9 \mathrm{R}-5, \\
70-73 \mathrm{~cm} \\
757 \mathrm{C}-\mathrm{F} 5\end{array}$ & $\begin{array}{c}757 \mathrm{C}- \\
9 \mathrm{R}-6, \\
102-105 \mathrm{~cm} \\
757 \mathrm{C}-\mathrm{F5}\end{array}$ & $\begin{array}{c}\text { 757C- } \\
9 \mathrm{R}-7, \\
78-82 \mathrm{~cm} \\
757 \mathrm{C}-\mathrm{F} 5\end{array}$ & $\begin{array}{c}757 \mathrm{C}- \\
9 \mathrm{R}-8, \\
54-59 \mathrm{~cm} \\
757 \mathrm{C}-\mathrm{F} 5\end{array}$ & $\begin{array}{c}757 \mathrm{C}- \\
10 \mathrm{R}-1, \\
86-90 \mathrm{~cm} \\
757 \mathrm{C}-\mathrm{F} 6\end{array}$ & $\begin{array}{c}757 \mathrm{C}- \\
10 \mathrm{R}-2, \\
66-70 \mathrm{~cm} \\
757 \mathrm{C}-\mathrm{F} 7\end{array}$ & $\begin{array}{c}757 \mathrm{C}- \\
10 \mathrm{R}-3, \\
2-6 \mathrm{~cm} \\
757 \mathrm{C}-\mathrm{F} 8\end{array}$ & $\begin{array}{c}757 \mathrm{C}- \\
10 \mathrm{R}-3, \\
83-87 \mathrm{~cm} \\
757 \mathrm{C}-\mathrm{F} 9\end{array}$ \\
\hline $\mathrm{SiO}_{2}$ & 49.35 & 49.21 & 48.76 & 48.45 & 48.60 & 47.19 & 48.14 & 47.57 & 48.05 & 47.64 & 48.68 & 48.15 & 48.18 & 48.20 & 47.87 \\
\hline $\mathrm{TiO}_{2}$ & 2.07 & 2.04 & 0.79 & 0.81 & 0.78 & 0.725 & 0.765 & 1.27 & 0.86 & 0.77 & 0.80 & 0.61 & 0.75 & 0.75 & 0.79 \\
\hline $\mathrm{Al}_{2} \mathrm{O}_{3}$ & 14.87 & 14.50 & 22.21 & 22.03 & 23.46 & 23.52 & 23.94 & 18.68 & 22.39 & 21.96 & 22.04 & 23.73 & 23.59 & 23.61 & 23.02 \\
\hline $\mathrm{Fe}_{2} \mathrm{O}_{3}$ & 12.02 & 12.10 & 6.82 & 6.85 & 5.69 & 6.66 & 6.86 & 11.25 & 6.73 & 8.14 & 6.87 & 5.93 & 5.79 & 5.83 & 7.17 \\
\hline $\mathrm{MnO}^{\circ}$ & 0.15 & 0.17 & 0.083 & 0.085 & 0.06 & 0.065 & 0.06 & 0.09 & 0.06 & 0.09 & 0.07 & 0.055 & 0.05 & 0.05 & 0.068 \\
\hline $\mathrm{MgO}$ & 7.28 & 7.11 & 5.88 & 5.71 & 5.52 & 4.27 & 4.76 & 6.32 & 5.60 & 5.14 & 5.97 & 5.18 & 5.33 & 5.28 & 5.42 \\
\hline $\mathrm{CaO}$ & 10.76 & 11.17 & 13.76 & 13.68 & 13.50 & 14.07 & 12.10 & 8.27 & 13.22 & 13.79 & 12.49 & 13.11 & 9.79 & 9.81 & 11.46 \\
\hline $\mathrm{Na}_{2} \mathrm{O}$ & 2.84 & 3.00 & 1.93 & 2.00 & 1.91 & 2.78 & 2.54 & 4.98 & 1.98 & 1.82 & 1.89 & 2.20 & 5.26 & 5.15 & 3.12 \\
\hline $\mathrm{K}_{2} \mathrm{O}$ & 0.56 & 0.248 & 0.14 & 0.15 & 0.281 & 0.767 & 0.997 & 1.775 & 1.12 & 0.641 & 0.99 & 1.16 & 1.68 & 1.67 & 1.32 \\
\hline $\mathrm{P}_{2} \mathrm{O}_{5}$ & 0.171 & 0.165 & 0.065 & 0.065 & 0.064 & 0.063 & 0.070 & 0.139 & 0.073 & 0.067 & 0.065 & 0.055 & 0.082 & 0.083 & 0.088 \\
\hline Sum & 100.09 & 99.71 & 100.44 & 99.84 & 99.88 & 100.11 & 100.23 & 100.34 & 100.09 & 100.06 & 99.87 & 100.18 & 100.50 & 100.43 & 100.32 \\
\hline $\mathrm{H}_{2} \mathrm{O}^{+}$ & 1.41 & 1.16 & 1.14 & 1.01 & 1.32 & 3.21 & 3.14 & 7.25 & 2.27 & 1.38 & 2.03 & 4.00 & 7.13 & 5.42 & 5.10 \\
\hline $\mathrm{H}_{2} \mathrm{O}^{-}$ & 0.93 & 0.62 & 1.00 & 0.91 & 1.12 & 0.72 & 0.67 & 1.11 & 0.33 & 0.70 & 0.54 & 0.61 & 1.51 & 1.54 & 1.61 \\
\hline $\mathrm{CO}_{2}$ & 0.18 & 0.19 & 0.24 & 0.36 & 0.46 & 1.38 & 0.24 & 0.50 & 1.02 & 0.50 & 0.35 & 1.09 & 1.99 & 0.73 & 1.33 \\
\hline $\mathrm{Fe}_{2} \mathrm{O}_{3} / \mathrm{FeO}$ & 1.76 & 0.79 & 0.83 & 0.83 & 0.94 & 2.96 & 3.39 & 3.75 & 2.20 & 1.83 & 1.49 & 2.69 & 4.98 & 3.41 & 3.17 \\
\hline $\mathrm{Na}_{2} \mathrm{O}$ (NA) & $2.62 \pm 0.01$ & 2.48 & 1.85 & $1.86 \pm 0.01$ & 1.88 & 2.43 & 2.32 & 3.98 & 1.87 & 1.76 & 1.87 & 1.96 & 4.32 & 3.49 & 2.74 \\
\hline & 41 & 1.9 & 1.4 & 1.6 & 1.8 & 9.3 & 10.6 & 13.6 & 34.7 & 17.7 & 22.1 & 17.2 & 14.5 & 17.1 & 16.7 \\
\hline Cs & $1.1 \pm 0.1$ & & - & - & - & 0.1 & 0.1 & 0.2 & 1.9 & 0.9 & 0.9 & 0.3 & 0.1 & 0.2 & 0.4 \\
\hline $\mathrm{Sr}$ & 169 & 163 & 176 & 182 & 201 & 375 & 313 & 455 & 215 & 181 & 184 & 247 & 388 & 559 & 432 \\
\hline $\mathrm{Ba}$ & 48 & 43 & 27 & 21.3 & 19 & 6.6 & 14 & 25 & 26 & 17 & 23 & 12 & 12 & 12 & 10 \\
\hline $\mathrm{Sc}$ & $43.4 \pm 0.3$ & 44.0 & 26.0 & $25.9 \pm 0.01$ & 24.0 & 21.5 & 22.5 & 36.2 & 25.4 & 24.3 & 24.3 & 20.7 & 19.5 & 19.3 & 22.6 \\
\hline $\mathrm{v}$ & 292 & 315 & 159 & 169 & 192 & 129 & 142 & 186 & 156 & 185 & 162 & 125 & 104 & 120 & 147 \\
\hline $\mathrm{Cr}$ & $200 \pm 1$ & 201 & 172 & $172 \pm 4$ & 161 & 137 & 142 & 230 & 155 & 152 & 157 & 160 & 160 & 141 & 146 \\
\hline Co & $46.8 \pm 0.1$ & 48.1 & 29.9 & $29.1 \pm 0.1$ & 26.7 & 24.3 & 25.1 & 37.5 & 30.1 & 28.0 & 29.5 & 22.0 & 18.4 & 20.4 & 24.1 \\
\hline $\mathrm{Ni}$ & 83 & 86 & 70 & 74 & 76 & 61 & 64 & 83 & 70 & 71 & 74 & 60 & 49 & 47 & 61 \\
\hline $\mathrm{Zn}$ & 105 & 103 & 54 & 51 & 55 & 50 & 52 & 79 & 54 & 49 & 53 & 42 & 40 & 47 & 48 \\
\hline Ga & 20 & 19 & 17.6 & 17.7 & 16.9 & 16.6 & 17.3 & 17.4 & 17.3 & 17.9 & 16.4 & 16.2 & 14.8 & 14.6 & 15.5 \\
\hline $\mathbf{Y}$ & 24.8 & 28.2 & 12.5 & 11.8 & 10.6 & 9.8 & 9.7 & 16.5 & 10.9 & 11.7 & 10.4 & 8.6 & 11.3 & 14.8 & 10.9 \\
\hline $\mathrm{Zr}$ & 118 & 119 & 48 & 49 & 49 & 45 & 46 & 73 & 52 & 47 & 49 & 34 & 39 & 40 & 45 \\
\hline $\mathrm{Nb}$ & 8.8 & 9.0 & 3.36 & 3.46 & 3.3 & 2.9 & 3.5 & 5.3 & 3.2 & 2.6 & 3.7 & 2.4 & 2.2 & 3.2 & 3.8 \\
\hline $\mathrm{Hf}$ & $2.80 \pm 0.01$ & 2.91 & 1.14 & $1.07 \pm 0.01$ & 1.13 & 0.93 & 0.98 & 1.71 & 1.07 & 1.12 & 1.14 & 0.71 & 0.95 & 0.85 & 0.97 \\
\hline Ta & $0.60 \pm 0.04$ & 0.62 & 0.18 & $0.23 \pm 0.01$ & 0.18 & 0.17 & 0.16 & 0.32 & 0.22 & 0.20 & 0.17 & 0.10 & 0.19 & 0.14 & 0.20 \\
\hline Th & $0.62 \pm 0.02$ & 0.68 & 0.33 & $0.29 \pm 0.03$ & 0.28 & 0.23 & 0.24 & 0.54 & 0.28 & 0.43 & 0.24 & 0.09 & 0.21 & 0.25 & 0.18 \\
\hline $\mathrm{La}$ & $7.24 \pm 0.09$ & 7.43 & 3.40 & $4.10 \pm 0.11$ & 3.26 & 2.94 & 3.10 & 5.01 & 3.67 & 3.27 & 3.08 & 2.35 & 3.52 & 3.85 & 3.11 \\
\hline $\mathrm{Ce}$ & $21.8 \pm 0.4$ & 21.0 & 8.5 & $9.8 \pm 0.4$ & 9.0 & 8.3 & 8.9 & 13.2 & 9.7 & 8.9 & 8.6 & 6.3 & 8.6 & 9.3 & 7.7 \\
\hline $\mathrm{Nd}$ & $12.8 \pm 0.1$ & 13.4 & 5.7 & $5.6 \pm 0.1$ & 5.3 & 4.6 & 5.2 & 8.1 & 4.6 & 5.3 & 5.1 & 4.0 & 5.8 & 5.9 & 5.0 \\
\hline $\mathrm{Sm}$ & $3.76 \pm 0.01$ & 4.17 & 1.57 & $1.56 \pm 0.02$ & 1.39 & 1.32 & 1.35 & 2.23 & 1.71 & 1.50 & 1.44 & 1.07 & 1.49 & 1.60 & 1.40 \\
\hline $\mathrm{Eu}$ & $1.38 \pm 0.01$ & 1.51 & 0.66 & $0.64 \pm 0.01$ & 0.62 & 0.58 & 0.57 & 0.85 & 0.65 & 0.62 & 0.62 & 0.49 & 0.61 & 0.64 & 0.60 \\
\hline $\mathrm{Tb}$ & $0.72 \pm 0.06$ & 0.87 & 0.25 & $0.34 \pm 0.01$ & 0.30 & 0.27 & 0.30 & 0.48 & 0.28 & 0.28 & 0.31 & 0.24 & 0.27 & 0.34 & 0.31 \\
\hline $\mathrm{Yb}$ & $2.28 \pm 0.10$ & 2.66 & 1.15 & $1.16 \pm 0.09$ & 1.00 & 1.10 & 0.92 & 1.52 & 1.10 & 1.11 & 1.10 & 0.83 & 1.01 & 1.22 & 1.10 \\
\hline Lu & $0.35 \pm 0.01$ & 0.40 & 0.18 & $0.21 \pm 0.01$ & 0.15 & 0.17 & 0.15 & 0.25 & 0.17 & 0.19 & 0.17 & 0.14 & 0.17 & 0.18 & 0.17 \\
\hline
\end{tabular}


Table 3 (continued).

\begin{tabular}{|c|c|c|c|c|c|c|c|c|c|c|c|c|c|c|}
\hline $\begin{array}{l}\text { Sample } \\
\text { Flow unit }\end{array}$ & $\begin{array}{c}757 \mathrm{C}- \\
11 \mathrm{R}-2, \\
10-14 \mathrm{~cm} \\
757 \mathrm{C}-\mathrm{F} 12\end{array}$ & $\begin{array}{c}757 \mathrm{C}- \\
11 \mathrm{R}-2, \\
51-56 \mathrm{~cm} \\
757 \mathrm{C}-\mathrm{F} 13\end{array}$ & $\begin{array}{c}757 \mathrm{C}- \\
12 \mathrm{R}-1, \\
100-104 \mathrm{~cm} \\
757 \mathrm{C}-\mathrm{F} 18\end{array}$ & $\begin{array}{c}757 \mathrm{C}- \\
12 \mathrm{R}-1, \\
104-110 \mathrm{~cm} \\
757 \mathrm{C}-\mathrm{F} 18\end{array}$ & $\begin{array}{c}757 \mathrm{C}- \\
12 \mathrm{R}-2, \\
0-5 \mathrm{~cm} \\
757 \mathrm{C}-\mathrm{F} 18\end{array}$ & $\begin{array}{c}757 \mathrm{C}- \\
12 \mathrm{R}-4, \\
24-29 \mathrm{~cm} \\
757 \mathrm{C}-\mathrm{F} 19\end{array}$ & $\begin{array}{c}758 \mathrm{~A}- \\
54 \mathrm{R}-2, \\
73-76 \mathrm{~cm} \\
758 \mathrm{~A}-\mathrm{F} 1(?)\end{array}$ & $\begin{array}{c}758 \mathrm{~A}- \\
55 \mathrm{R}-2, \\
84-88 \mathrm{~cm} \\
758 \mathrm{~A}-\mathrm{F} 1\end{array}$ & $\begin{array}{c}758 \mathrm{~A}- \\
55 \mathrm{R}-5, \\
82-86 \mathrm{~cm} \\
758 \mathrm{~A}-\mathrm{F} 1\end{array}$ & $\begin{array}{c}758 \mathrm{~A}- \\
56 \mathrm{R}-1, \\
64-68 \mathrm{~cm} \\
758 \mathrm{~A}-\mathrm{F} 1\end{array}$ & $\begin{array}{c}758 \mathrm{~A}- \\
57 \mathrm{R}-3, \\
18-22 \mathrm{~cm} \\
758 \mathrm{~A}-\mathrm{F} 2\end{array}$ & $\begin{array}{c}758 \mathrm{~A}- \\
58 \mathrm{R}-3, \\
62-66 \mathrm{~cm} \\
758 \mathrm{~A}-\mathrm{F} 2\end{array}$ & $\begin{array}{c}758 \mathrm{~A}- \\
58 \mathrm{R}-6, \\
21-25 \mathrm{~cm} \\
758 \mathrm{~A}-\mathrm{F} 2\end{array}$ & $\begin{array}{c}758 \mathrm{~A}- \\
59 \mathrm{R}-2, \\
58-62 \mathrm{~cm} \\
758 \mathrm{~A}-\mathrm{F} 2\end{array}$ \\
\hline $\mathrm{SiO}_{2}$ & 49.52 & 50.15 & 51.80 & 51.67 & 50.49 & 51.10 & 49.72 & 49.28 & 49.52 & 49.49 & 49.04 & 49.77 & 49.97 & 49.61 \\
\hline $\mathrm{TiO}_{2}$ & 1.01 & 1.00 & 0.98 & 0.96 & 0.92 & 0.98 & 1.40 & 1.06 & 1.12 & 1.21 & 1.54 & 1.17 & 2.04 & 1.30 \\
\hline $\mathrm{Al}_{2} \mathrm{O}_{3}$ & 20.32 & 19.60 & 18.58 & 18.71 & 18.36 & 19.42 & 17.50 & 15.80 & 16.17 & 16.44 & 16.11 & 14.04 & 13.00 & 14.14 \\
\hline $\mathrm{Fe}_{2} \mathrm{O}_{3}$ & 8.33 & 8.93 & 7.61 & 7.50 & 9.84 & 8.90 & 11.33 & 10.93 & 10.55 & 10.76 & 13.05 & 12.69 & 16.28 & 12.52 \\
\hline $\mathrm{MnO}$ & 0.08 & 0.09 & 0.17 & 0.17 & 0.11 & 0.08 & 0.16 & 0.14 & 0.12 & 0.20 & 0.19 & 0.17 & 0.23 & 0.15 \\
\hline $\mathrm{MgO}$ & 6.94 & 5.88 & 5.18 & 5.26 & 5.38 & 5.28 & 7.43 & 7.75 & 7.96 & 8.18 & 8.68 & 9.46 & 8.08 & 8.39 \\
\hline $\mathrm{CaO}$ & 9.27 & 7.80 & 12.05 & 12.00 & 10.64 & 7.25 & 9.20 & 12.15 & 12.17 & 11.12 & 7.47 & 9.97 & 7.20 & 11.20 \\
\hline $\mathrm{Na}_{2} \mathrm{O}$ & 3.03 & 4.48 & 2.80 & 2.67 & 2.62 & 4.63 & 3.27 & 2.15 & 2.14 & 2.37 & 3.14 & 2.44 & 2.78 & 2.36 \\
\hline $\mathrm{K}_{2} \mathrm{O}$ & 1.62 & 1.98 & 0.77 & 0.76 & 1.28 & 2.13 & 0.171 & 0.097 & 0.082 & 0.116 & 0.409 & 0.129 & 0.15 & 0.14 \\
\hline $\mathrm{P}_{2} \mathrm{O}_{5}$ & 0.076 & 0.076 & 0.080 & 0.076 & 0.073 & 0.079 & 0.094 & 0.089 & 0.075 & 0.084 & 0.145 & 0.092 & 0.195 & 0.103 \\
\hline Sum & 100.20 & 99.99 & 100.02 & 99.77 & 99.71 & 99.87 & 100.28 & 99.45 & 99.92 & 99.97 & 99.77 & 99.93 & 99.93 & 99.91 \\
\hline $\mathrm{H}_{2} \mathrm{O}^{+}$ & 5.27 & 5.13 & 1.43 & 1.36 & 1.02 & 3.82 & 1.29 & & 0.99 & 1.14 & 1.81 & & 1.65 & 1.09 \\
\hline $\mathrm{H}_{2} \mathrm{O}^{-}$ & 1.72 & 1.27 & 0.76 & 0.70 & 0.79 & 1.01 & 3.09 & & 0.92 & 1.01 & 3.56 & & 2.54 & 2.02 \\
\hline $\mathrm{CO}_{2}$ & 0.91 & 0.75 & 0.38 & 0.28 & 0.21 & 0.30 & 0.43 & & 0.15 & 0.24 & 0.48 & & 0.29 & 0.18 \\
\hline $\mathrm{Fe}_{2} \mathrm{O}_{3} / \mathrm{FeO}$ & 2.47 & 3.52 & 0.51 & 0.64 & 1.32 & 2.89 & 1.35 & 0.94 & 1.12 & 1.41 & & & 1.30 & 0.88 \\
\hline $\mathrm{Na}_{2} \mathrm{O}$ (NA) & 2.71 & 3.98 & 2.48 & $2.44 \pm 0.03$ & 2.45 & 4.04 & $2.76 \pm 0.05$ & 1.96 & $2.04 \pm 0.05$ & $2.26 \pm 0.01$ & $2.76 \pm 0.03$ & 2.16 & 2.51 & $2.10 \pm 0.02$ \\
\hline & 19.1 & 19.9 & 7.8 & 7.1 & 20.0 & 14.4 & 0.86 & 0.71 & 0.44 & 1.4 & 1.0 & 2.2 & 1.1 & 2.2 \\
\hline Cs & 0.3 & 0.3 & - & - & 0.3 & - & - & & - & - & - & - & - & - \\
\hline $\mathrm{Sr}$ & 324 & 292 & 164 & 168 & 160 & 150 & 148 & 121 & 127 & 154 & 162 & 129 & 143 & 127 \\
\hline $\mathrm{Ba}$ & 27 & 24 & 76 & 81 & 80 & 126 & 17.8 & 15.5 & 9.9 & 17.2 & 28.8 & 25.8 & 33.5 & 36.8 \\
\hline $\mathrm{Sc}$ & 29.2 & 29.2 & 28.9 & $28.4 \pm 0.1$ & 27.9 & 27.8 & $48.8 \pm 0.6$ & 41.5 & $44.6 \pm 0.2$ & $47.2 \pm 0.5$ & $50.6 \pm 0.5$ & 44.7 & 44.3 & $45.7 \pm 0.1$ \\
\hline $\mathrm{v}$ & 174 & 183 & 201 & 195 & 221 & 157 & 369 & 274 & 316 & 348 & 399 & 301 & 433 & 334 \\
\hline $\mathrm{Cr}$ & 110 & 114 & 99 & $96 \pm 1$ & 96 & 99 & $222 \pm 1$ & 182 & $216 \pm 1$ & $227 \pm 1$ & $103 \pm 3$ & 101 & 8 & $116 \pm 1$ \\
\hline Co & 29.5 & 28.0 & 30.7 & $29.8 \pm 0.2$ & 30.0 & 27.1 & $66.9 \pm 1.0$ & 41.8 & $45.7 \pm 0.4$ & $51.0 \pm 0.8$ & $41.1 \pm 0.3$ & 47.7 & 42.5 & $49.6 \pm 0.6$ \\
\hline $\mathrm{Ni}$ & 52 & 48 & 50 & 50 & 52 & 48 & 88 & 70 & 84 & 83 & 73 & 68 & 32 & 77 \\
\hline $\mathrm{Zn}$ & 60 & 56 & 76 & 73 & 77 & 85 & 99 & 78 & 72 & 71 & 106 & 70 & 125 & 89 \\
\hline $\mathrm{Ga}$ & 16.2 & 13.9 & 18.9 & 17.5 & 18.5 & 18.7 & 16.6 & 16.4 & 16.6 & 17.6 & 17.5 & 15.9 & 20.5 & 15.8 \\
\hline $\mathbf{Y}$ & 13.8 & 11.8 & 29.6 & 28.6 & 29.4 & 31.5 & 15.9 & 21.2 & 17.9 & 17.1 & 24.6 & 21.7 & 37.6 & 23.2 \\
\hline $\mathrm{Zr}$ & 57 & 59 & 163 & 162 & 157 & 199 & 71 & 59 & 48 & 57 & 86 & 60 & 126 & 69 \\
\hline $\mathrm{Nb}$ & 4.5 & 4.0 & 9.56 & 10.4 & 9.3 & 11.7 & 5.1 & 3.8 & 2.7 & 3.1 & 5.7 & 4.0 & 8.08 & 4.47 \\
\hline $\mathrm{Hf}$ & 1.35 & 1.41 & 3.67 & $3.51 \pm 0.01$ & 3.45 & 4.52 & $1.90 \pm 0.22$ & 1.51 & $1.24 \pm 0.05$ & $1.40 \pm 0.02$ & $1.91 \pm 0.14$ & 1.58 & 3.03 & $1.77 \pm 0.01$ \\
\hline $\mathrm{Ta}$ & 0.28 & 0.19 & 0.61 & $0.54 \pm 0.01$ & 0.53 & 0.71 & $0.30 \pm 0.03$ & 0.21 & $0.2 \pm 0.1$ & $0.16 \pm 0.01$ & $0.26 \pm 0.11$ & 0.24 & 0.50 & $0.23 \pm 0.01$ \\
\hline Th & 0.35 & 0.34 & 1.53 & $1.63 \pm 0.01$ & 1.48 & 1.89 & $0.25 \pm 0.13$ & 0.34 & 0.17 & 0.23 & $0.35 \pm 0.11$ & 0.29 & 0.73 & $0.26 \pm 0.04$ \\
\hline La & 4.41 & 3.95 & 10.9 & $11.2 \pm 0.01$ & 10.4 & 12.6 & $3.44 \pm 0.14$ & 3.15 & $2.63 \pm 0.06$ & $2.78 \pm 0.01$ & $5.78 \pm 0.04$ & 3.44 & 6.88 & $3.96 \pm 0.04$ \\
\hline $\mathrm{Ce}$ & 10.8 & 9.9 & 27.0 & $27.0 \pm 0.3$ & 25.9 & 30.8 & $9.8 \pm 0.7$ & 9.82 & $6.9 \pm 0.7$ & $8.3 \pm 0.3$ & $15.6 \pm 0.8$ & 10.3 & 21.2 & $10.6 \pm 0.8$ \\
\hline $\mathrm{Nd}$ & 6.1 & 6.0 & 14.4 & $14.0 \pm 0.1$ & 14.3 & 16.0 & $6.7 \pm 0.6$ & 6.6 & $5.0 \pm 0.4$ & $5.3 \pm 0.4$ & $10.8 \pm 1.0$ & 7.3 & 14.2 & $7.66 \pm 0.08$ \\
\hline $\mathrm{Sm}$ & 1.82 & 1.67 & 3.77 & $3.70 \pm 0.08$ & 3.70 & 4.30 & $2.16 \pm 0.08$ & 2.20 & $1.79 \pm 0.04$ & $1.90 \pm 0.26$ & $3.31 \pm 0.13$ & 2.30 & 4.22 & $2.44 \pm 0.01$ \\
\hline Eu & 0.74 & 0.67 & 1.15 & $1.12 \pm 0.01$ & 1.10 & 1.22 & $0.84 \pm 0.02$ & 0.77 & $0.72 \pm 0.02$ & $0.73 \pm 0.01$ & $1.19 \pm 0.01$ & 0.81 & 1.50 & $0.95 \pm 0.01$ \\
\hline $\mathrm{Tb}$ & 0.35 & 0.39 & 0.72 & $0.70 \pm 0.07$ & 0.78 & 0.85 & $0.46 \pm 0.07$ & 0.51 & $0.43 \pm 0.04$ & $0.47 \pm 0.01$ & $0.68 \pm 0.04$ & 0.50 & 1.00 & $0.53 \pm 0.01$ \\
\hline $\mathrm{Yb}$ & 1.40 & 1.28 & 3.02 & $2.84 \pm 0.01$ & 3.17 & 3.08 & $1.78 \pm 0.04$ & 2.18 & $1.85 \pm 0.10$ & $1.92 \pm 0.01$ & $2.30 \pm 0.04$ & 2.19 & 3.84 & $2.39 \pm 0.13$ \\
\hline $\mathrm{Lu}$ & 0.21 & 0.19 & 0.46 & $0.44 \pm 0.02$ & 0.51 & 0.48 & $0.26 \pm 0.01$ & 0.33 & $0.28 \pm 0.01$ & $0.28 \pm 0.01$ & $0.31 \pm 0.01$ & 0.34 & 0.60 & $0.36 \pm 0.01$ \\
\hline
\end{tabular}


Table 3 (continued).

\begin{tabular}{|c|c|c|c|c|c|c|c|c|c|c|c|c|c|c|}
\hline $\begin{array}{l}\text { Sample } \\
\text { Flow unit }\end{array}$ & $\begin{array}{c}758 \mathrm{~A}- \\
59 \mathrm{R}-6, \\
61-65 \mathrm{~cm} \\
758 \mathrm{~A}-\mathrm{F} 2\end{array}$ & $\begin{array}{c}758 \mathrm{~A}- \\
60 \mathrm{R}-1 \text {, } \\
41-45 \mathrm{~cm} \\
758 \mathrm{~A}-\mathrm{F} 2\end{array}$ & $\begin{array}{c}758 \mathrm{~A}- \\
60 \mathrm{R}-1, \\
122-126 \mathrm{~cm} \\
758 \mathrm{~A}-\mathrm{F} 3\end{array}$ & $\begin{array}{c}\text { 758A- } \\
60 \mathrm{R}-3, \\
18-22 \mathrm{~cm} \\
758 \mathrm{~A}-\mathrm{F} 3\end{array}$ & $\begin{array}{c}\text { 758A- } \\
61 \mathrm{R}-5, \\
22-26 \mathrm{~cm} \\
758 \mathrm{~A}-\mathrm{F} 3\end{array}$ & $\begin{array}{c}758 \mathrm{~A}- \\
62 \mathrm{R}-1, \\
130-134 \mathrm{~cm} \\
758 \mathrm{~A}-\mathrm{F} 4\end{array}$ & $\begin{array}{c}\text { 758A- } \\
62 \mathrm{R}-3, \\
80-84 \mathrm{~cm} \\
758 \mathrm{~A}-\mathrm{F} 5\end{array}$ & $\begin{array}{c}758 \mathrm{~A}- \\
63 \mathrm{R}-3, \\
114-118 \mathrm{~cm} \\
758 \mathrm{~A}-\mathrm{F} 7\end{array}$ & $\begin{array}{c}758 \mathrm{~A}- \\
65 \mathrm{R}-1, \\
51-55 \mathrm{~cm} \\
758 \mathrm{~A}-\mathrm{F} 10\end{array}$ & $\begin{array}{c}\text { 758A- } \\
66 \mathrm{R}-4, \\
6-12 \mathrm{~cm} \\
758 \mathrm{~A}-\mathrm{F} 11\end{array}$ & $\begin{array}{c}758 \mathrm{~A}- \\
66 \mathrm{R}-4, \\
29-33 \mathrm{~cm} \\
758 \mathrm{~A}-\mathrm{F} 11\end{array}$ & $\begin{array}{c}758 \mathrm{~A}- \\
67 \mathrm{R}-2, \\
92-96 \mathrm{~cm} \\
758 \mathrm{~A}-\mathrm{F} 13\end{array}$ & $\begin{array}{c}758 \mathrm{~A}- \\
67 \mathrm{R}-4, \\
31-35 \mathrm{~cm} \\
758 \mathrm{~A}-\mathrm{F} 14\end{array}$ & $\begin{array}{c}758 \mathrm{~A}- \\
67 \mathrm{R}-5, \\
86-90 \mathrm{~cm} \\
758 \mathrm{~A}-\mathrm{F} 15\end{array}$ \\
\hline $\mathrm{SiO}_{2}$ & 49.80 & 49.69 & 49.85 & 49.60 & 49.76 & 48.75 & 49.35 & 49.68 & 49.81 & 50.04 & 49.27 & 49.51 & 49.88 & 49.63 \\
\hline $\mathrm{TiO}_{2}^{2}$ & 1.35 & 1.28 & 1.45 & 1.50 & 1.37 & 1.02 & 1.66 & 1.60 & 1.61 & 1.36 & 1.32 & 1.35 & 1.66 & 1.46 \\
\hline $\mathrm{Al}_{2} \mathrm{O}_{3}$ & 14.04 & 14.57 & 14.33 & 13.93 & 14.07 & 18.78 & 16.10 & 14.58 & 16.71 & 15.00 & 15.03 & 15.04 & 14.80 & 16.25 \\
\hline $\mathrm{Fe}_{2} \mathrm{O}_{3}$ & 12.38 & 12.50 & 13.12 & 13.08 & 12.34 & 8.20 & 12.20 & 12.34 & 11.51 & 11.30 & 10.81 & 11.40 & 11.96 & 11.03 \\
\hline $\mathrm{MnO}$ & 0.18 & 0.18 & 0.11 & 0.18 & 0.15 & 0.19 & 0.22 & 0.16 & 0.19 & 0.21 & 0.22 & 0.19 & 0.23 & 0.20 \\
\hline $\mathrm{MgO}$ & 8.28 & 8.90 & 9.00 & 9.37 & 8.52 & 8.15 & 9.43 & 8.92 & 9.11 & 9.45 & 9.15 & 9.48 & 9.51 & 9.03 \\
\hline $\mathrm{CaO}$ & 10.68 & 9.50 & 9.59 & 9.28 & 11.43 & 12.66 & 7.70 & 9.84 & 8.42 & 10.48 & 11.04 & 10.32 & 9.16 & 9.18 \\
\hline $\mathrm{Na}_{2} \mathrm{O}$ & 2.41 & 2.76 & 2.60 & 2.43 & 2.17 & 2.01 & 2.89 & 2.51 & 2.81 & 2.37 & 2.41 & 2.17 & 2.47 & 2.71 \\
\hline $\mathrm{K}_{2} \mathrm{O}$ & 0.152 & 0.154 & 0.088 & 0.13 & 0.113 & 0.114 & 0.166 & 0.121 & 0.100 & 0.13 & 0.117 & 0.052 & 0.070 & 0.110 \\
\hline $\mathrm{P}_{2} \mathrm{O}_{5}$ & 0.116 & 0.108 & 0.113 & 0.117 & 0.105 & 0.066 & 0.143 & 0.118 & 0.123 & 0.095 & 0.098 & 0.096 & 0.126 & 0.109 \\
\hline Sum & 99.38 & 99.64 & 100.25 & 99.62 & 100.01 & 99.92 & 99.86 & 99.89 & 100.39 & 100.43 & 99.47 & 99.61 & 99.88 & 99.70 \\
\hline $\mathrm{H}_{2} \mathrm{O}^{+}$ & & & 1.44 & 1.88 & 1.08 & 1.49 & 1.90 & 1.30 & 1.92 & 1.45 & & 1.70 & 1.73 & 1.43 \\
\hline $\mathrm{H}_{2} \mathrm{O}^{-}$ & & & 1.95 & 1.53 & 1.45 & 1.34 & 3.07 & 1.93 & 3.39 & 1.75 & & 2.09 & 2.92 & 2.58 \\
\hline $\mathrm{CO}_{2}$ & & & 0.43 & 0.26 & 0.13 & 0.35 & 0.41 & 0.37 & 0.45 & 0.38 & & 0.38 & 0.47 & 0.45 \\
\hline $\mathrm{Fe}_{2} \mathrm{O}_{3} / \mathrm{FeO}$ & & & 0.93 & 1.09 & 0.98 & 0.84 & 1.61 & 1.24 & 1.43 & 1.10 & & 1.27 & 1.42 & 1.41 \\
\hline $\mathrm{Na}_{2} \mathrm{O}(\mathrm{NA})$ & 2.17 & 2.24 & 2.33 & $2.23 \pm 0.03$ & 2.09 & 1.89 & 2.65 & 2.21 & 2.52 & $2.15 \pm 0.03$ & 2.08 & 2.12 & 2.36 & 2.34 \\
\hline $\mathrm{Rb}^{2}$ & 3.1 & 2.0 & 0.61 & 0.99 & 1.30 & 0.91 & 0.74 & 0.79 & 0.35 & 0.99 & 1.1 & - & 0.20 & 0.56 \\
\hline Cs & - & 0.3 & - & - & - & & - & - & - & - & - & - & - & - \\
\hline $\mathrm{Sr}$ & 131 & 135 & 131 & 132 & 127 & 139 & 157 & 140 & 157 & 136 & 137 & 132 & 144 & 144 \\
\hline $\mathrm{Ba}$ & 41.2 & 12.7 & 4.4 & 27.2 & 17.6 & 18.8 & 12.5 & 14.8 & 13.0 & 11.8 & 14.7 & 8.6 & 8.0 & 18.4 \\
\hline $\mathrm{Sc}$ & 47.2 & 46.5 & 47.8 & $46.6 \pm 0.3$ & 47.3 & 39.1 & 51.6 & 47.2 & 52.4 & $47.6 \pm 0.1$ & 47.9 & 46.5 & 49.4 & 46.5 \\
\hline $\mathrm{v}$ & 331 & 328 & 326 & 353 & 321 & 234 & 372 & 359 & 371 & 304 & 305 & 316 & 374 & 348 \\
\hline $\mathrm{Cr}$ & 100 & 101 & 182 & $154 \pm 0.7$ & 194 & 336 & 229 & 200 & 364 & $332 \pm 6$ & 358 & 349 & 183 & 246 \\
\hline Co & 52.2 & 51.9 & 35.2 & $50.1 \pm 0.1$ & 48.5 & 43.2 & 38.9 & 47.9 & 41.1 & $48.4 \pm 0.3$ & 48.8 & 47.5 & 52.8 & 47.4 \\
\hline $\mathrm{Ni}$ & 72 & 79 & 78 & 80 & 83 & 117 & 66 & 74 & 82 & 97 & 98 & 106 & 80 & 76 \\
\hline $\mathrm{Zn}$ & 87 & 84 & 89 & 108 & 87 & 66 & 109 & 81 & 101 & 75 & 74 & 84 & 94 & 89 \\
\hline $\mathrm{Ga}$ & 17.2 & 17.1 & 17.1 & 17.7 & 17.0 & 15.7 & 17.8 & 18.2 & 18.2 & 17.2 & 16.8 & 17.2 & 19.2 & 18.3 \\
\hline $\mathrm{Y}$ & 24.5 & 22.2 & 22.5 & 24.5 & 23.4 & 14.4 & 25.1 & 23.3 & 19.3 & 20.2 & 22.2 & 19.9 & 23.0 & 19.4 \\
\hline $\mathrm{Zr}$ & 77 & 71 & 77 & 80 & 74 & 50 & 89 & 84 & 85 & 69 & 69 & 71 & 91 & 78 \\
\hline $\mathrm{Nb}$ & 5.0 & 4.5 & 5.2 & 5.6 & 4.4 & 3.4 & 5.4 & 5.8 & 5.6 & 4.1 & 4.1 & 4.4 & 5.8 & 4.1 \\
\hline $\mathrm{Hf}$ & 2.10 & 1.77 & 1.72 & $2.09 \pm 0.08$ & 1.83 & 1.25 & 2.31 & 2.04 & 2.18 & $1.72 \pm 0.01$ & 1.61 & 1.92 & 2.40 & 1.88 \\
\hline Ta & 0.37 & 0.32 & 0.26 & $0.38 \pm 0.01$ & 0.35 & 0.19 & 0.37 & 0.34 & 0.31 & $0.29 \pm 0.01$ & 0.24 & 0.23 & 0.34 & 0.24 \\
\hline Th & 0.28 & 0.24 & 0.43 & $0.54 \pm 0.18$ & 0.63 & 0.23 & 0.27 & 0.41 & 0.33 & - & 0.27 & 0.21 & 0.19 & 0.20 \\
\hline $\mathrm{La}$ & 4.52 & 3.91 & 4.71 & $4.83 \pm 0.04$ & 4.61 & 2.75 & 5.67 & 4.61 & 4.33 & $7.32 \pm 0.18$ & 4.08 & 3.38 & 4.65 & 4.10 \\
\hline $\mathrm{Ce}$ & 13.2 & 11.6 & 12.7 & $14.8 \pm 0.5$ & 13.4 & 7.9 & 16.4 & 14.1 & 12.3 & $10.5 \pm 0.3$ & 12.3 & 9.6 & 14.8 & 11.7 \\
\hline Nd & 8.8 & 8.0 & 9.0 & $9.3 \pm 0.2$ & 9.5 & 5.5 & 10.9 & 8.8 & 9.0 & $7.64 \pm 0.02$ & 8.7 & 6.3 & 10.4 & 8.2 \\
\hline $\mathrm{Sm}$ & 2.79 & 2.43 & 2.55 & $2.83 \pm 0.01$ & 2.67 & 1.66 & 3.40 & 2.79 & 2.61 & $2.33 \pm 0.06$ & 2.80 & 2.26 & 2.74 & 2.30 \\
\hline $\mathrm{Eu}$ & 1.01 & 0.90 & 0.98 & $1.04 \pm 0.01$ & 1.02 & 0.68 & 1.22 & 1.06 & 1.01 & $0.93 \pm 0.03$ & 0.98 & 0.91 & 1.06 & 0.94 \\
\hline $\mathrm{Tb}$ & 0.73 & 0.50 & 0.54 & $0.64 \pm 0.03$ & 0.59 & 0.35 & 0.67 & 0.56 & 0.48 & $0.53 \pm 0.08$ & 0.66 & 0.44 & 0.63 & 0.55 \\
\hline $\mathrm{Yb}$ & 2.44 & 2.26 & 2.23 & $2.58 \pm 0.03$ & 2.33 & 1.45 & 2.39 & 2.30 & 1.91 & $2.12 \pm 0.01$ & 2.07 & 2.21 & 2.44 & 1.99 \\
\hline Lu & 0.41 & 0.33 & 0.35 & $0.39 \pm 0.01$ & 0.36 & 0.23 & 0.37 & 0.39 & 0.27 & $0.32 \pm 0.01$ & 0.33 & 0.33 & 0.37 & 0.29 \\
\hline
\end{tabular}


Table 3 (continued).

\begin{tabular}{|c|c|c|c|c|c|c|c|c|c|c|c|c|c|c|c|}
\hline $\begin{array}{l}\text { Sample } \\
\text { Flow unit }\end{array}$ & $\begin{array}{c}758 \mathrm{~A}- \\
69 \mathrm{R}-1, \\
37-43 \mathrm{~cm} \\
758 \mathrm{~A}-\mathrm{F} 17\end{array}$ & $\begin{array}{c}758 \mathrm{~A}- \\
69 \mathrm{R}-3, \\
53-57 \mathrm{~cm} \\
758 \mathrm{~A}-\mathrm{F} 17\end{array}$ & $\begin{array}{c}\text { 758A- } \\
70 \mathrm{R}-1, \\
71-75 \mathrm{~cm} \\
758 \mathrm{~A}-\mathrm{F} 18\end{array}$ & $\begin{array}{c}758 \mathrm{~A}- \\
70 \mathrm{R}-2, \\
129-133 \mathrm{~cm} \\
758 \mathrm{~A}-\mathrm{F} 19\end{array}$ & $\begin{array}{c}758 \mathrm{~A}- \\
71 \mathrm{R}-1, \\
127-131 \mathrm{~cm} \\
758 \mathrm{~A}-\mathrm{F} 20\end{array}$ & $\begin{array}{c}758 \mathrm{~A}- \\
71 \mathrm{R}-2, \\
136-140 \mathrm{~cm} \\
758 \mathrm{~A}-\mathrm{F} 21\end{array}$ & $\begin{array}{c}758 \mathrm{~A}- \\
71 \mathrm{R}-3, \\
64-68 \mathrm{~cm} \\
758 \mathrm{~A}-\mathrm{F} 22\end{array}$ & $\begin{array}{c}758 \mathrm{~A}- \\
71 \mathrm{R}-3 \\
140-144 \mathrm{~cm} \\
758 \mathrm{~A}-\mathrm{F} 23\end{array}$ & $\begin{array}{c}758 \mathrm{~A}- \\
72 \mathrm{R}-2, \\
95-99 \mathrm{~cm} \\
758 \mathrm{~A}-\mathrm{F} 24\end{array}$ & $\begin{array}{c}758 \mathrm{~A}- \\
74 \mathrm{R}-4, \\
53-57 \mathrm{~cm} \\
758 \mathrm{~A}-\mathrm{F} 25\end{array}$ & $\begin{array}{c}758 \mathrm{~A}- \\
74 \mathrm{R}-6, \\
71-75 \mathrm{~cm} \\
758 \mathrm{~A}-\mathrm{F} 26\end{array}$ & $\begin{array}{c}758 \mathrm{~A}- \\
73 \mathrm{R}-1 \\
129-133 \mathrm{~cm} \\
758 \mathrm{~A}-\mathrm{F} 27\end{array}$ & $\begin{array}{c}\text { 758A- } \\
73 \mathrm{R}-2 . \\
127-131 \mathrm{~cm} \\
758 \mathrm{~A}-\mathrm{F} 27\end{array}$ & $\begin{array}{c}758 \mathrm{~A} . \\
73 \mathrm{R}-3 . \\
136-140 \mathrm{~cm} \\
758 \mathrm{~A}-\mathrm{F} 28\end{array}$ & $\begin{array}{c}758 \mathrm{~A}- \\
73 \mathrm{R}-4 \\
64-68 \mathrm{~cm} \\
758 \mathrm{~A}-\mathrm{F} 29\end{array}$ \\
\hline $\mathrm{SiO}_{2}$ & 49.68 & 49.11 & 49.27 & 49.49 & 49.64 & 49.79 & 49.88 & 49.81 & 49.86 & 49.45 & 49.88 & 49.90 & 49.66 & 49.56 & 49.74 \\
\hline $\mathrm{TiO}_{2}$ & 1.39 & 1.20 & 1.50 & 1.29 & 1.30 & 1.30 & 1.31 & 1.32 & 1.28 & 1.40 & 1.18 & 1.38 & 1.21 & 1.31 & 1.34 \\
\hline $\mathrm{Al}_{2} \mathrm{O}_{3}$ & 15.18 & 13.97 & 15.68 & 15.39 & 15.97 & 14.70 & 15.02 & 15.16 & 15.01 & 16.20 & 15.58 & 14.83 & 15.54 & 15.30 & 14.74 \\
\hline $\mathrm{Fe}_{2} \mathrm{O}_{3}$ & 11.26 & 11.27 & 11.19 & 11.14 & 10.75 & 12.73 & 11.06 & 11.14 & 11.15 & 10.69 & 10.75 & 11.70 & 10.78 & 11.86 & 11.98 \\
\hline $\mathrm{MnO}$ & 0.18 & 0.24 & 0.25 & 0.20 & 0.22 & 0.14 & 0.23 & 0.21 & 0.24 & 0.25 & 0.23 & 0.24 & 0.24 & 0.20 & 0.19 \\
\hline $\mathrm{MgO}$ & 8.38 & 9.60 & 9.60 & 10.21 & 9.57 & 9.85 & 9.26 & 9.64 & 9.53 & 9.15 & 9.69 & 9.71 & 8.94 & 9.92 & 8.92 \\
\hline $\mathrm{CaO}$ & 11.76 & 12.09 & 9.13 & 9.43 & 9.66 & 8.51 & 11.02 & 10.37 & 10.95 & 10.01 & 10.50 & 9.84 & II. 12 & 9.22 & 10.56 \\
\hline $\mathrm{Na}_{2} \mathrm{O}$ & 2.28 & 1.97 & 2.82 & 2.36 & 2.50 & 2.44 & 2.12 & 2.27 & 2.20 & 2.42 & 2.26 & 2.39 & 2.13 & 2.45 & 2.24 \\
\hline $\mathrm{K}_{2} \mathrm{O}$ & 0.092 & 0.105 & 0.092 & 0.077 & 0.127 & 0.210 & 0.046 & 0.054 & 0.049 & 0.057 & 0.060 & 0.117 & 0.057 & 0.073 & 0.105 \\
\hline $\mathrm{P}_{2} \mathrm{O}_{5}$ & 0.101 & 0.091 & 0.113 & 0.110 & 0.104 & 0.100 & 0.105 & 0.106 & 0.101 & 0.116 & 0.100 & 0.105 & 0.092 & 0.143 & 0.107 \\
\hline Sum & 100.31 & 99.64 & 99.65 & 99.71 & 99.85 & 99.77 & 100.04 & 100.08 & 100.37 & 99.75 & 100.23 & 100.21 & 99.77 & 100.04 & 99.92 \\
\hline $\mathrm{H}_{2} \mathrm{O}^{+}$ & 1.43 & 1.36 & 1.76 & 1.77 & 1.54 & 2.12 & 1.17 & 1.44 & 1.39 & 1.50 & 1.37 & 1.46 & - & 1.90 & 1.42 \\
\hline $\mathrm{H}_{2}^{-} \mathrm{O}^{-}$ & 1.59 & 2.25 & 3.95 & 3.95 & 3.10 & 3.76 & 2.53 & 3.25 & 2.97 & 3.60 & 3.28 & 3.95 & - & 4.06 & 2.13 \\
\hline $\mathrm{CO}_{2}$ & 0.21 & 0.74 & 0.44 & 0.44 & 0.60 & 0.55 & 0.45 & 0.40 & 0.38 & 0.45 & 0.37 & 0.44 & - & 0.66 & 0.37 \\
\hline $\mathrm{Fe}_{2} \mathrm{O}_{3} / \mathrm{FeO}$ & 1.03 & 0.91 & 1.35 & 1.34 & 1.39 & 1.21 & 1.22 & 1.29 & 1.20 & 1.48 & 1.13 & 1.34 & - & 1.26 & 1.19 \\
\hline $\mathrm{Na}_{2} \mathrm{O}$ (NA) & $2.00 \pm 0.01$ & 1.82 & 2.27 & 2.14 & 2.29 & $2.16 \pm 0.04$ & $1.98 \pm 0.02$ & $2.02 \pm 0.04$ & $1.98 \pm 0.05$ & $2.18 \pm 0.04$ & $2.03 \pm 0.01$ & 2.14 & $1.98 \pm 0.02$ & 2.13 & 2.02 \\
\hline & 0.74 & 0.73 & 0.11 & 0.54 & 0.78 & 2.5 & 0.13 & 0.31 & 0.23 & 0.51 & 0.55 & - & - & 0.39 & 1.5 \\
\hline Cs & $=$ & - & - & - & - & - & - & - & - & - & - & - & - & - & - \\
\hline Sr & 135 & 114 & 140 & 125 & 130 & 121 & 122 & 122 & 121 & 133 & 118 & 121 & 116 & 115 & 113 \\
\hline $\mathrm{Ba}$ & 24.5 & 17.5 & 19.3 & 9.0 & 5.5 & 11.6 & 7.2 & 6.1 & 13.4 & 6.2 & 2.1 & 9.1 & 22 & 23 & 11 \\
\hline Sc & $44.6 \pm 0.4$ & 46.4 & 48.9 & 47.8 & 50.1 & $44.5 \pm 0.01$ & $46.8 \pm 0.4$ & $46.2 \pm 0.5$ & $47.0 \pm 0.8$ & $48.6 \pm 0.4$ & $47.8 \pm 0.5$ & 48.5 & $46.1 \pm 0.04$ & 45.3 & 46.9 \\
\hline $\mathrm{v}$ & 294 & 272 & 370 & 324 & 325 & 310 & 316 & 317 & 316 & 347 & 323 & 344 & 324 & 334 & 324 \\
\hline $\mathrm{Cr}$ & $256 \pm 8$ & 397 & 210 & 214 & 234 & $196 \pm 0.7$ & $214 \pm 1$ & $211 \pm 3$ & $218 \pm 4$ & $226 \pm 4$ & $162 \pm 0.7$ & 180 & $176 \pm 2$ & 111 & 213 \\
\hline Co & $46.6 \pm 0.1$ & 48.8 & 50.8 & 44.4 & 49.1 & $68.1 \pm 0.1$ & $47.5 \pm 0.4$ & $47.8 \pm 0.5$ & $48.6 \pm 0.5$ & $46.0 \pm 0.4$ & $54.8 \pm 1$ & 51.6 & $46.6 \pm 0.7$ & 32.6 & 47.6 \\
\hline $\mathrm{Ni}$ & 81 & 106 & 86 & 81 & 81 & 87 & 85 & 84 & 85 & 85 & 86 & 83 & 83 & 72 & 88 \\
\hline $\mathrm{Zn}$ & 113 & 75 & 83 & 103 & 89 & 98 & 98 & 97 & 90 & 106 & 99 & 96 & 93 & 137 & 90 \\
\hline $\mathrm{Ga}$ & 17.3 & 16.5 & 17.7 & 16.9 & 16.7 & 15.9 & 16.6 & 16.9 & 16.6 & 16.8 & 16.4 & 17.7 & 16.7 & 18.8 & 16.5 \\
\hline $\mathrm{Y}$ & 23.5 & 22.3 & 19.1 & 19.0 & 17.8 & 23.0 & 20.8 & 19.0 & 20.0 & 18.6 & 17.7 & 21.8 & 19.7 & 24.4 & 21.0 \\
\hline $\mathrm{Zr}$ & 73 & 62 & 81 & 68 & 68 & 69 & 69 & 69 & 66 & 76 & 63 & 72 & 66 & 74 & 72 \\
\hline $\mathrm{Nb}$ & 4.88 & 3.6 & 5.4 & 5.2 & 42 & 4.9 & 4.6 & 4.9 & 4.2 & 5.3 & 4.7 & 4.9 & 4.6 & 5.2 & 4.5 \\
\hline $\mathrm{Hf}$ & $1.82 \pm 0.08$ & 1.49 & 1.83 & 1.68 & 1.56 & $1.74 \pm 0.15$ & $1.74 \pm 0.06$ & $1.75 \pm 0.14$ & $1.80 \pm 0.44$ & $1.98 \pm 0.06$ & $1.50 \pm 0.02$ & 1.81 & $1.52 \pm 0.08$ & 1.73 & 1.74 \\
\hline $\mathrm{Ta}$ & $0.30 \pm 0.04$ & 0.26 & 0.36 & 0.27 & 0.23 & $0.28 \pm 0.05$ & $0.30 \pm 0.05$ & $0.24 \pm 0.12$ & $0.23 \pm 0.01$ & $0.24 \pm 0.08$ & $0.27 \pm 0.12$ & 0.31 & $0.24 \pm 0.03$ & 0.23 & 0.38 \\
\hline Th & $0.38 \pm 0.11$ & 0.28 & 0.22 & 0.25 & 0.27 & $0.32 \pm 0.06$ & $0.33 \pm 0.01$ & $0.36 \pm 0.04$ & $0.34 \pm 0.02$ & $0.28 \pm 0.01$ & $0.20 \pm 0.08$ & 0.41 & $0.23 \pm 0.05$ & 0.35 & 0.26 \\
\hline La & $4.12 \pm 0.03$ & 3.70 & 4.11 & 3.74 & 3.82 & $4.04 \pm 0.02$ & $3.84 \pm 0.06$ & $3.79 \pm 0.13$ & $3.58 \pm 0.06$ & $3.90 \pm 0.14$ & $3.29 \pm 0.01$ & 3.91 & $3.49 \pm 0.12$ & 4.85 & 4.17 \\
\hline $\mathrm{Ce}$ & $12.2 \pm 0.01$ & 11.4 & 11.5 & 10.6 & 10.6 & $13.0 \pm 0.4$ & $11.5 \pm 0.6$ & $10.2 \pm 0.5$ & $10.8 \pm 0.1$ & $11.4 \pm 0.2$ & $9.5 \pm 0.1$ & 11.4 & $9.6 \pm 0.4$ & 12.9 & 12.8 \\
\hline Nd & $7.8 \pm 0.6$ & 8.3 & 8.3 & 7.8 & 7.9 & $8.45 \pm 0.07$ & $7.3 \pm 0.6$ & $7.4 \pm 0.7$ & $7.0 \pm 0.2$ & $8.0 \pm 0.1$ & $6.6 \pm 0.4$ & 7.0 & $6.4 \pm 0.9$ & 8.8 & 8.3 \\
\hline $\mathrm{Sm}$ & $2.52 \pm 0.06$ & 2.35 & 2.33 & 2.16 & 2.09 & $2.56 \pm 0.04$ & $2.30 \pm 0.07$ & $2.26 \pm 0.01$ & $2.24 \pm 0.01$ & $2.28 \pm 0.02$ & $2.02 \pm 0.04$ & 2.27 & $2.14 \pm 0.06$ & 2.42 & 2.46 \\
\hline Eu & $0.94 \pm 0.01$ & 0.91 & 0.91 & 0.82 & 0.84 & $0.94 \pm 0.04$ & $0.87 \pm 0.01$ & $0.84 \pm 0.01$ & $0.86 \pm 0.01$ & $0.84 \pm 0.01$ & $0.79 \pm 0.01$ & 0.91 & $0.82 \pm 0.02$ & 0.93 & 0.95 \\
\hline $\mathrm{Tb}$ & $0.55 \pm 0.01$ & 0.56 & 0.43 & 0.49 & 0.44 & $0.62 \pm 0.05$ & $0.51 \pm 0.01$ & $0.47 \pm 0.04$ & $0.48 \pm 0.04$ & $0.58 \pm 0.08$ & $0.48 \pm 0.04$ & 0.47 & $0.52 \pm 0.07$ & 0.63 & 0.56 \\
\hline $\mathrm{Yb}$ & $2.27 \pm 0.06$ & 2.09 & 1.84 & 1.85 & 1.85 & $2.44 \pm 0.07$ & $2.19 \pm 0.10$ & $2.06 \pm 0.04$ & $2.14 \pm 0.08$ & $2.06 \pm 0.05$ & $2.05 \pm 0.06$ & 2.43 & $2.08 \pm 0.05$ & 2.27 & 2.48 \\
\hline Lu & $0.36 \pm 0.01$ & 0.33 & 0.31 & 0.28 & 0.27 & $0.38 \pm 0.01$ & $0.32 \pm 0.01$ & $0.32 \pm 0.01$ & $0.30 \pm 0.01$ & $0.30 \pm 0.01$ & $0.30 \pm 0.01$ & 0.37 & $0.33 \pm 0.01$ & 0.35 & 0.36 \\
\hline
\end{tabular}



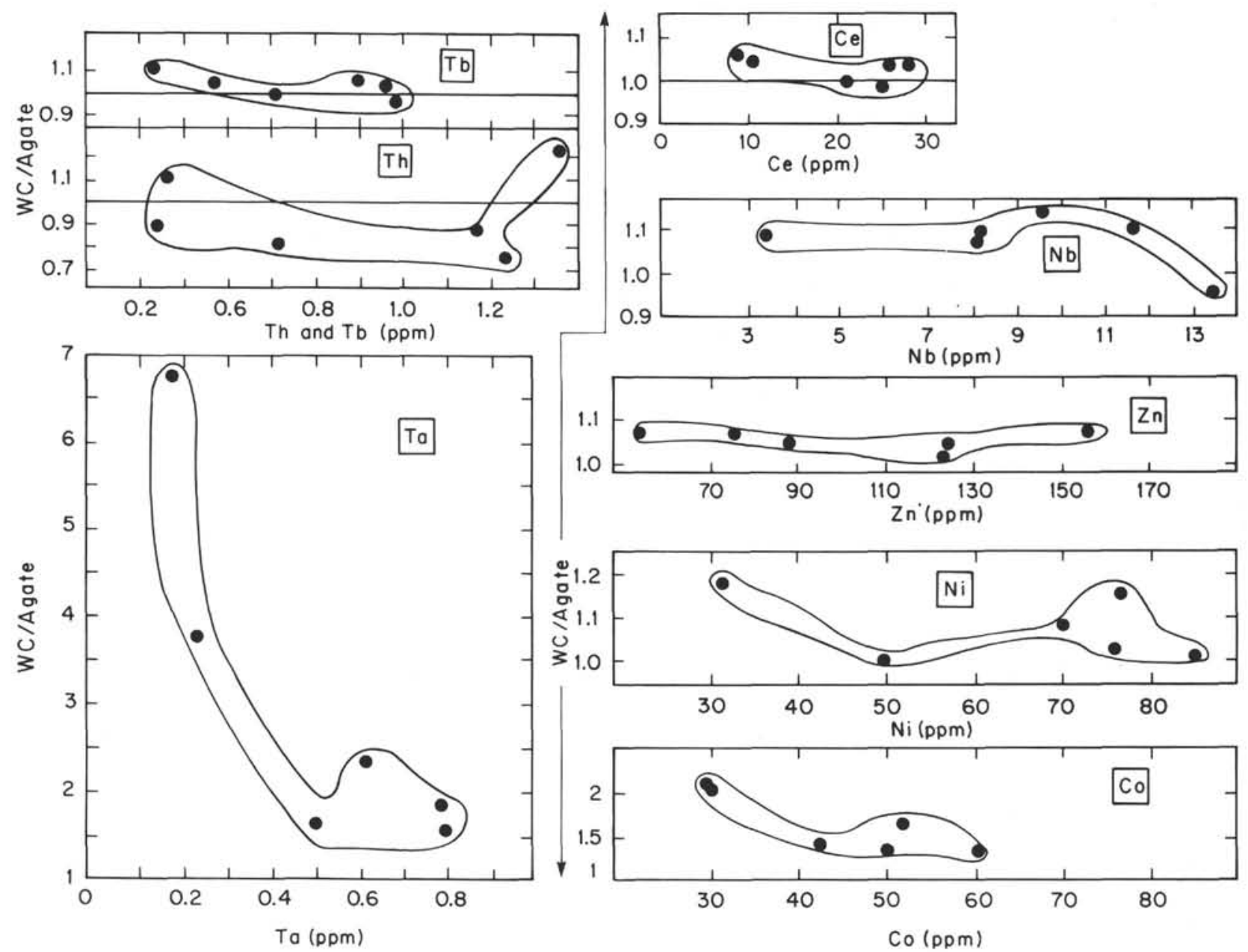

Figure 2. Comparison of selected trace element contents in aliquots of Leg 121 basalts (see Table 2) powdered in tungsten carbide (WC) and agate crushing containers. Note the extreme $\mathrm{Co}$ and $\mathrm{Ta}$ contamination and moderate $\mathrm{Zn}$ and $\mathrm{Nb}$ contamination introduced by crushing in WC.

sites. We infer that most of these intersite geochemical differences reflect magmatic processes and differences in source composition. The implications of these intersite compositional differences will be discussed later.

\section{Site 756}

In Hole $756 \mathrm{C}, 5.99 \mathrm{~m}$ of basement was recovered from a penetration of $8.7 \mathrm{~m}$, and in Hole 756D, $26.92 \mathrm{~m}$ of basement was recovered from a penetration of $82 \mathrm{~m}$. Based on the ages of overlying sediments, the lavas are $>38 \mathrm{Ma}$ (Shipboard Scientific Party, 1989b). Duncan (this volume) reported ${ }^{40} \mathrm{Ar} /{ }^{39} \mathrm{Ar}$ ages of $\sim 42-44 \mathrm{Ma}$. We analyzed one sample from flow Unit 756C-F1 and 15 samples from nine of the 14 different flow units recognized in Hole 756D (Table 3 and Fig. 8A). The abundant vesicles and cavities are consistent with subaerial eruption, and there is no evidence that these flows erupted in a submarine environment (Shipboard Scientific Party, 1989b). Lavas from Site 756 are generally finely holocrystalline, sparsely plagioclase-phyric, sparsely amygdaloidal, moderately altered basalts. Alteration minerals are abundant smectite with zeolites and calcite in amygdules and veinlets. The petrography of Sample 121-756C-10N-1, $32-36 \mathrm{~cm}$, is typical for this site. It contains plagioclase laths zoned from $\mathrm{An}_{63} \mathrm{Ab}_{36} \mathrm{Or}_{1}$ to $\mathrm{An}_{49} \mathrm{Ab}_{48} \mathrm{Or}_{3}$, and clinopyroxenes have compositions within the field for transitional basalts (cf. Figs. 5A and 5E). Additional petrographic descriptions and mineral composition data are in Appendices A and B.
Compared to basalts from other holes drilled in Ninetyeast Ridge during Leg 121, basalts from Hole 756D define the most coherent trends; for example, as $\mathrm{MgO}$ content decreases, abundances of $\mathrm{CaO}$ decrease, $\mathrm{Al}_{2} \mathrm{O}_{3}$ and $\mathrm{Na}_{2} \mathrm{O}$ increase slightly, and $\mathrm{TiO}_{2}$ and $\mathrm{P}_{2} \mathrm{O}_{5}$ increase significantly (Fig. 6). The uppermost samples from Hole 756D, from flow Units 756D-F1, 756D-F2, and $756 \mathrm{D}-\mathrm{F} 4$, have the lowest $\mathrm{MgO}$ content and the highest abundances of $\mathrm{Fe}_{2} \mathrm{O}_{3}, \mathrm{TiO}_{2}, \mathrm{P}_{2} \mathrm{O}_{5}$, and incompatible trace elements (Table 3 and Fig. 6). In particular, Sample 121-756D-6R-1, 6-10 cm, from flow Unit 756D-F4 has the highest abundances of $\mathrm{TiO}_{2}, \mathrm{P}_{2} \mathrm{O}_{5}, \mathrm{Nb}, \mathrm{Ta}, \mathrm{Th}$, and light REE (LREE) (Table 3 and Figs. 6 and 7). In addition, lavas from these uppermost flow units of Hole $756 \mathrm{D}$ have the highest $\mathrm{FeO}^{*} / \mathrm{MgO}, \sim 2.5$, found in basement lavas from Leg 121 (Fig. 4).

Abundances of the first series transition metals, (Sc, V, Co, and $\mathrm{Zn}$ ) increase as $\mathrm{MgO}$ contents decrease (Table 3 and Fig. 6). In contrast, $\mathrm{Cr}$ abundances decrease with decreasing $\mathrm{MgO}$ content, but $\mathrm{Ni}$ contents are surprisingly constant, 74-90 ppm in 15 of the 16 samples from Site 756 (Table 3 and Fig. 6). Abundances of the highly incompatible elements $\mathrm{Th}, \mathrm{Ba}, \mathrm{Nb}, \mathrm{Ta}, \mathrm{LREE}, \mathrm{P}, \mathrm{Zr}$, and $\mathrm{Hf}$ in lavas from Hole 756D are strongly correlated and range by factors of 1.6-2.7, with Th having the largest range (Table 3 and Fig. 7). Abundances of Sr, Y, and heavy Ree (HREE) are also positively correlated with these highly incompatible elements, but their abundance range is only a factor of $\sim 1.3-1.4$ (Table 3 and Fig. 7). The chondrite-normalized REE patterns are all subparallel 

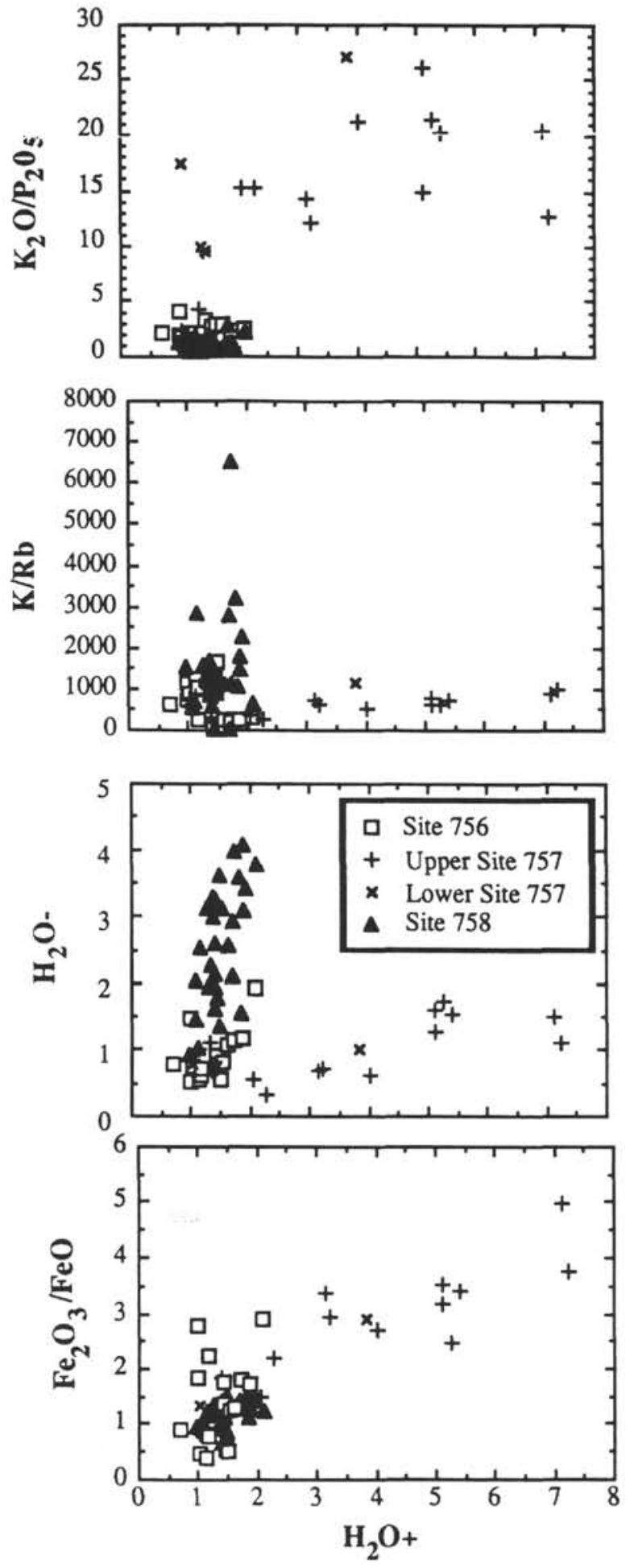

Figure 3. Various indices of low-temperature alteration in the Leg 121 lavas. Very high $\mathrm{H}_{2} \mathrm{O}^{+}$(water released at $1100^{\circ} \mathrm{C}$ ) and $\mathrm{Fe}_{2} \mathrm{O}_{3} / \mathrm{FeO}$ occur in many Hole $757 \mathrm{C}$ lavas whereas lavas from $\mathrm{Hole} 758 \mathrm{~A}$ have very high $\mathrm{H}_{2} \mathrm{O}^{-}$contents (water released at $110^{\circ} \mathrm{C}$ ). The abundance ratios $\mathrm{K} / \mathrm{Rb}$ and $\mathrm{K}_{2} \mathrm{O} / \mathrm{P}_{2} \mathrm{O}_{5}$ were also significantly changed by postmagmatic alteration; specifically, $\mathrm{K}_{2} \mathrm{O} / \mathrm{P}_{2} \mathrm{O}_{5}$ ratios $<1$ and $>5$ are interpreted to reflect the loss and addition of $\mathrm{K}_{2} \mathrm{O}$, respectively. Most lavas with low $\mathrm{K}_{2} \mathrm{O}(<0.3 \%)$ have very high $(>1000) \mathrm{K} / \mathrm{Rb}$. In this plot and subsequent plots, the lowermost flow units at Hole $757 \mathrm{C}$, $757 \mathrm{C}-18$ and $757 \mathrm{C}-19$, are indicated by $\times$ 's.
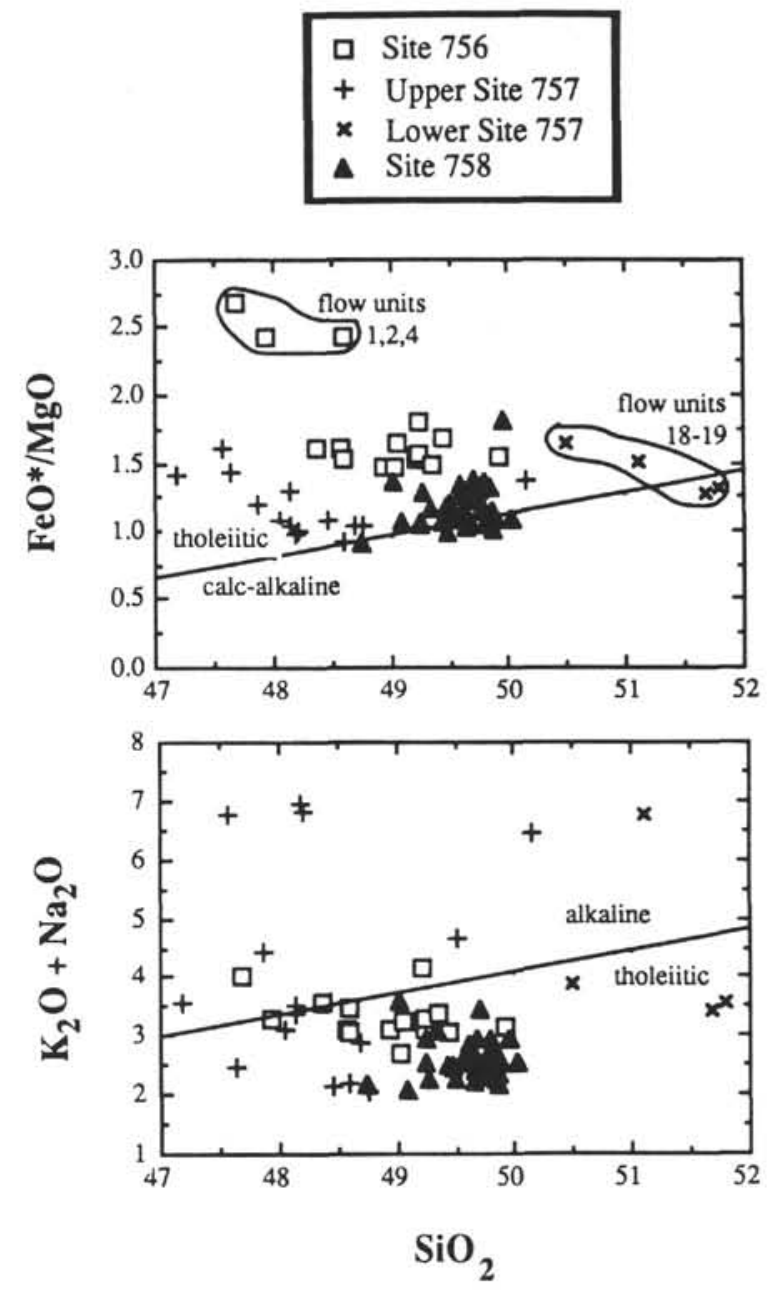

Figure 4. Two classification schemes for distinguishing alkaline, tholeiitic, and calc-alkaline types of basalt. The plot of $\mathrm{Na}_{2} \mathrm{O}+\mathrm{K}_{2} \mathrm{O}$ vs. $\mathrm{SiO}_{2}$ (all in wt\%) shows that all lavas from Site 758 and most of the lavas from Sites 756 and 757 are in the tholeiitic field (dividing line from Macdonald and Katsura, 1964). Because the $\mathrm{K}_{2} \mathrm{O}$ and in some cases $\mathrm{Na}_{2} \mathrm{O}$ contents of Leg 121 basalts have been modified by postmagmatic alteration, this plot may not accurately reflect the basalt type. For example, the five Hole $757 \mathrm{C}$ lavas with very high alkali contents represent a late-stage process that converted $\mathrm{Ca}$-rich plagioclase to $\mathrm{Na}$-rich plagioclase. The $\mathrm{FeO}^{*} / \mathrm{MgO}-\mathrm{SiO}_{2}$ plot proposed by Miyashiro (1974) to distinguish tholeiitic and calc-alkaline lavas is less sensitive to low-temperature alteration, and the majority of Leg 121 lavas are in the tholeiitic field. $\mathrm{FeO}^{*}$ is all $\mathrm{Fe}$ reported as $\mathrm{FeO}$.

and are typical of enriched mid-ocean ridge basalts (MORBs) and oceanic island tholeiitic basalts (Figs. 9A and 9D). For example, the field defined by Hole 756D lavas encompasses the pattern for some MORBs dredged from the Southwest Indian Ridge near the triple junction (Fig. 9D). Also, the shallow slope from La through Eu, with $(\mathrm{La} / \mathrm{Ce})_{\mathrm{N}}<1$ (subscript $N$ indicates chondrite normalized) is typical of Hawaiian tholeiitic basalts, although Hawaiian tholeiitic basalts have lower HREE contents (Fig. 9D).

The systematic compositional trends defined by lavas from Site 756 may reflect their nearly aphyric texture, their relatively lower degree of postmagmatic alteration, and perhaps a relatively simple petrogenetic history. For example, the increasing incompatible element abundance with decreasing $\mathrm{MgO}$ content is characteristic of fractional crystallization involving phases such as olivine, pyroxenes, and plagioclase. Plagioclase and, to a lesser extent, clinopyroxene occur as phenocryst phases in lavas from 
$\mathrm{Ca}$

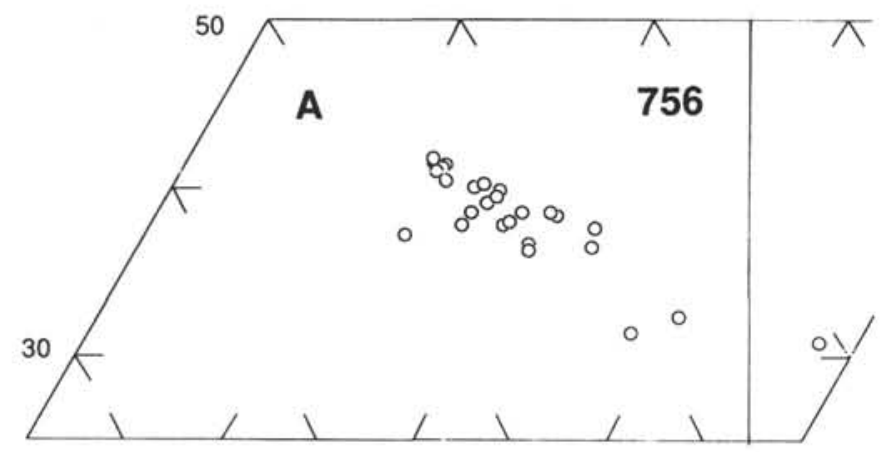

$\mathrm{Fe}$

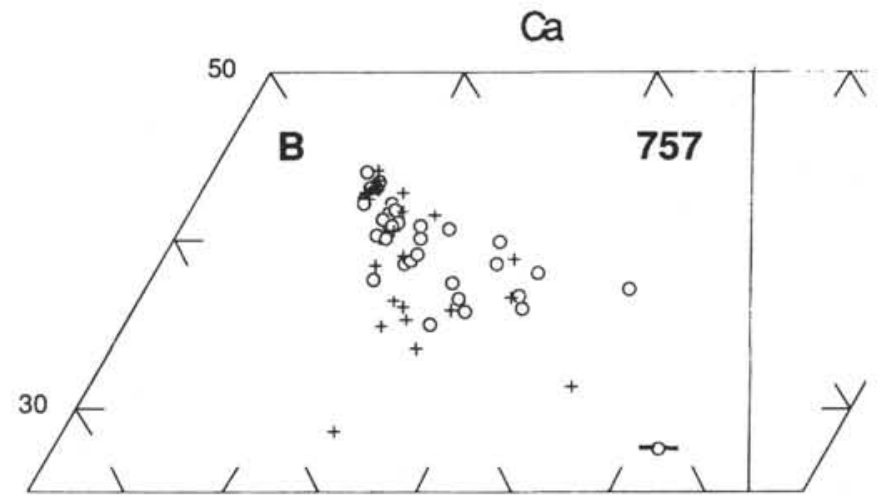

$\mathrm{Mg}$

$\mathrm{Fe}$

$\mathrm{Ca}$

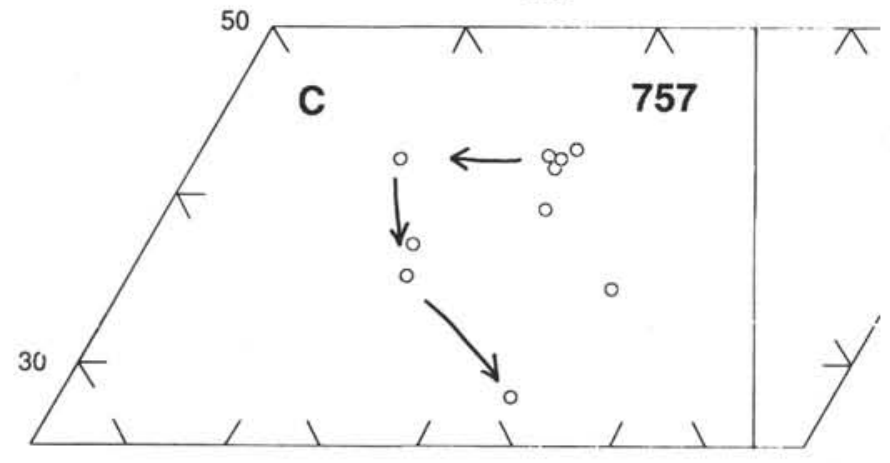

Mg

$\mathrm{Fe}$

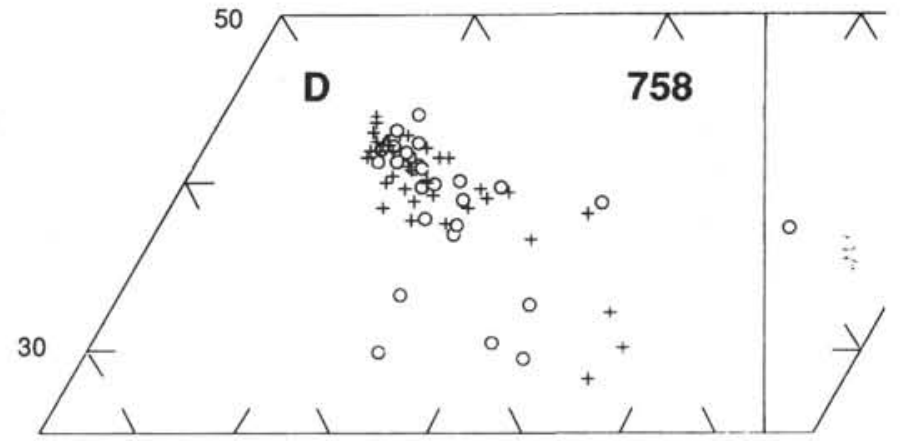

$\mathrm{Mg}$

$\mathrm{Fe}$

Ca

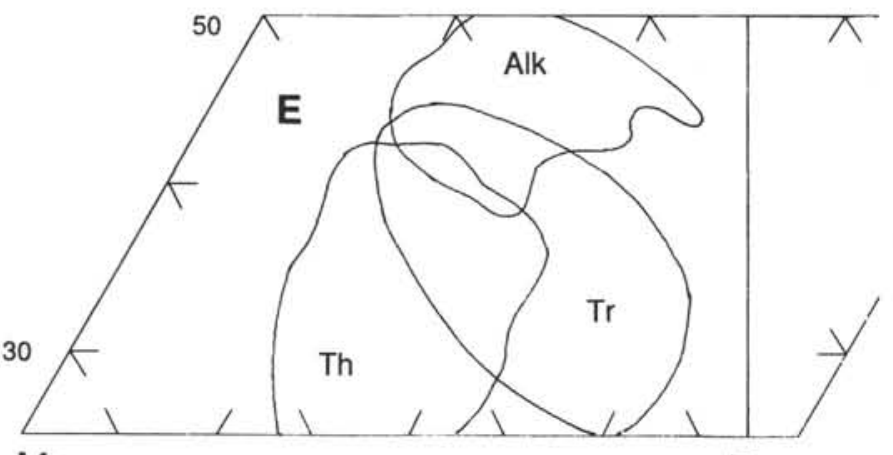

Mg

$\mathrm{Fe}$

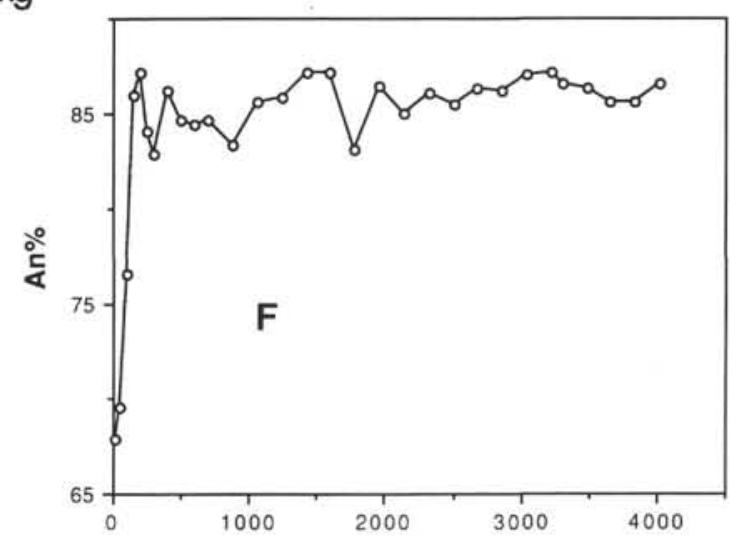

\section{Microns from rim}

Figure 5. Clinopyroxene compositions (Appendix B) in lavas from Sites 756, 757, and 758 (plots A-D) and fields for clinopyroxene in alkalic, transitional, and tholeiitic basalts (plot E). There are few clinopyroxene phenocrysts in these cores, and most of the data points are for microphenocrysts (see petrographic descriptions in Appendix A). The quadrilaterals are part of the compositional triangle $\mathrm{CaSiO}_{3}, \mathrm{MgSiO}_{3}$, and $\mathrm{FeSiO}_{3}$. A. Clinopyroxene compositions in lavas from Site 756 overlap with the field defined by clinopyroxenes from transitional basalts; however, clinopyroxenes from Site 756 are generally richer in Fe than those from other sites. B. Clinopyroxenes from the upper flow units (757C-F1-757C-F13, circles) also have compositions within the transitional field, but the compositions of clinopyroxenes from flow Units 757C-F18 and 757C-F19 (+'s) trend into the tholeiitic field. The "winged" circle in this plot represents analyses of two small ferroaugite inclusions in a plagioclase phenocryst. Although the low $\mathrm{Ca}$ content of these grains may reflect interaction with the plagioclase host, the higher $\mathrm{Fe} / \mathrm{Mg}$ suggests that these clinopyroxene inclusions in plagioclase crystallized from a melt that was more evolved than the parental melt of the clinopyroxene microphenocrysts. C. Clinopyroxenes in Sample 121-757C-12R-2, 0-5 cm, from flow Unit 757C-F18, include reversely zoned microphenocrysts that have a relatively Fe-rich (Fs 19\%) cores zoned to Fe-poor (Fs10\%) rims with outer rims that trend (arrows) into the tholeitic compositional field. D. Clinopyroxene compositions from the thick upper flow units (758A-F1-758A-F3, circles) are in the tholeitic and transitional fields; however, clinopyroxene compositions in the lower flow units (+'s) are entirely in the transitional field. None of the clinopyroxenes in the Leg 121 basalts has a composition solely within the alkalic field. E. Comparison plot of the compositional fields for clinopyroxene from Hawaiian tholeiites (Th) (Basalt Volcanism Study Project, 1981) and from alkalic (Alk) and transitional ( $\mathrm{Tr}$ ) basalts of the Kerguelen Archipelago (Gautier, 1987). F. Compositional variations in a typical plagioclase megacryst from Hole 757C. Note the very calcic core composition, the fine oscillatory zoning, and the narrow, strongly zoned reaction rim. 
Site 756 , but no unaltered olivine was observed, although possible pseudomorphs after olivine are present in one sample (see Appendix A). The lack of strong petrographic evidence for olivine combined with the absence of a positive correlation between $\mathrm{MgO}$ and $\mathrm{Ni}$ abundances (Fig. 6) may indicate that olivine fractionation was not important during the crustal evolution of these lavas. However, decreasing $\mathrm{CaO} / \mathrm{Al}_{2} \mathrm{O}_{3}$ with decreasing $\mathrm{MgO}$ requires a significant role for clinopyroxene segregation (Fig. 10), but the increasing Sc content with decreasing $\mathrm{MgO}$ in the Site 756 lavas shows that the effects of clinopyroxene segregation were diluted by Sc-poor phases such as plagioclase (Fig. 6). The limited increase in $\mathrm{Sr}$ content with decreasing $\mathrm{MgO}$ and increasing $\mathrm{La}$ contents (Fig. 7) is consistent with plagioclase plus clinopyroxene segregation, but plagioclase fractionation was not sufficient to create negative Eu anomalies (Fig. 9A).

However, there are some complexities in the chondrite-normalized REE patterns which are not consistent with fractional crystallization of the phenocryst phases. For example, relative to samples from flow Units 756D-F9 and 756D-F12, the sample from flow Unit 756D-F7 has higher LREE, but similar Y and $\mathrm{Yb}$ contents (Table 3 and Fig. 9A). This sample has the highest $\mathrm{La} / \mathrm{Sm}$ and $\mathrm{La} / \mathrm{Yb}$ of the Site 756 lavas, which range in $(\mathrm{La} / \mathrm{Sm})_{\mathrm{N}}$ from 1.10 to 1.44 and in $(\mathrm{La} / \mathrm{Yb})_{\mathrm{N}}$ from 1.88 to 2.59 . The crossing REE pattern (Fig. 9A) suggests that flow Unit 756D-F7 was derived from a compositionally different parent than the other lavas sampled at Site 756. This inference is collaborated by isotopic data; specifically, compared with other lavas from Site 756, the sample from flow Unit $756 \mathrm{D}-\mathrm{F} 7$ has the highest initial ${ }^{87} \mathrm{Sr} /{ }^{86} \mathrm{Sr}(0.70457$, acid-leached), a relatively low $\varepsilon_{\mathrm{Nd}}{ }^{(1.9)}$, and slightly higher $\mathrm{Pb}$ isotopic ratios (Weis and Frey, this volume). Despite these geochemical differences, the sample from flow Unit 756D-F7 is not distinctive in petrography or mineral composition (see Appendices).

There are other compositional data that are inconsistent with simple fractional crystallization. The most obvious is the lack of correlation between abundances of $\mathrm{Rb}$ and other incompatible elements (Fig. 7). In the Site 756 lavas $\mathrm{Rb}$ abundance ranges from 1.1 to $70 \mathrm{ppm}$, which is an order of magnitude more variation than that of the other incompatible elements. Abundances of $\mathrm{K}_{2} \mathrm{O}$ are also quite variable, by a factor of 4.3 , and $\mathrm{K} / \mathrm{Rb}$ ratios range from a low of 73 (flow Unit 756D-F6) to a high of 1672 (flow Unit $756 \mathrm{D}-\mathrm{F} 5$ ), which is from less than average oceanic island basalt to greater than average MORB. Within flow Unit 756D-F5, K/Rb varies from 120 to 1672 and $\mathrm{K}_{2} \mathrm{O} / \mathrm{P}_{2} \mathrm{O}_{5}$ varies from 1.28 to 2.76 . In contrast, within this flow unit abundance ratios involving other incompatible elements vary by less than $11 \%$ (Table 3 and Fig. 11). It is evident that $K$ and $R b$ contents have been affected by postmagmatic processes.

Another geochemical effect of the extensive alteration is the variation in Th/U ratios (Fig. 11). Although lavas from Site 756 appear to be less altered than lavas from Sites 757 and 758, the highest $\mathrm{Th} / \mathrm{U}$ ratios are in the uppermost lavas from Hole $756 \mathrm{D}$. Specifically, lavas from the lower units have $\mathrm{Th} / \mathrm{U}$ ratios of $\sim 2.7-4.0$, whereas $\mathrm{Th} / \mathrm{U}$ ranges from $\sim 8$ to 21 in five lavas from flow Units 756D-F1, 756D-F2, 756D-F4, and 756D-F5, which are from the upper $20 \mathrm{~m}$ of the Hole 756D basalt section. We infer that $U$ has been preferentially mobilized from the uppermost lavas in these cores.

As noted during shipboard study, lavas from Hole 756D show two types of alteration, commonly side by side with sharp contacts: an earlier, blue-green alteration and a later, brown (oxidized) alteration (see descriptions of Samples 121-756D-6R-2, 13 $\mathrm{cm}$, and 121-756D-7R-3, 50-54 cm, in Appendix A). Petrographic and electron microprobe study demonstrate that the brown alteration is later than the blue-green alteration and that the contact commonly coincides with the introduction of vein calcite.
The characteristic alteration mineral of the blue-green zone is a green-black, iron-rich saponite, and the brown zone contains an interstratified saponite-glauconite (nomenclature after Newman and Brown, 1987; analyses and atomic formulas in Appendix B, Sample 121-756D-7R-3, 50-54 cm). The saponite-glauconite has higher $\mathrm{Al}_{2} \mathrm{O}_{3}, \mathrm{FeO}^{*}$, and $\mathrm{K}_{2} \mathrm{O}$ and lower $\mathrm{Na}_{2} \mathrm{O}$ content than the saponite. Whole-rock abundances of adjacent blue-green and brown zones (Samples 121-756D-6R-2, 13-17 cm, and 121$756 \mathrm{D}-6 \mathrm{R}-2,9-13 \mathrm{~cm}$, respectively) show marked differences in $\mathrm{K}_{2} \mathrm{O}(0.23 \%$ vs. $0.49 \%), \mathrm{Rb}$ (1 vs. 33 ppm), and $\mathrm{Fe}_{2} \mathrm{O}_{3} / \mathrm{FeO}(0.51$ vs. 1.24) plus slightly lower $\mathrm{CaO}$ and $\mathrm{MgO}$ abundances in the brown portion (Table 3 ). A shipboard study of the brown and blue-green parts of Sample 121-756D-11R-2, 123-130 cm, yielded similar results (Shipboard Scientific Party, 1989b). The blue-green and brown samples have, nevertheless, very similar abundances of incompatible elements such as $\mathrm{P}, \mathrm{Y}, \mathrm{Zr}, \mathrm{Hf}, \mathrm{Nb}$, $\mathrm{Ta}$, Th, and REE (Table 3). Also, both samples have high but similar Th/U ratios ( 8, Fig. 11).

The blue-green and brown alteration represent successive events. The initial process of blue-green alteration formed greenblack, K-poor, Fe-rich saponite (Appendix B) and resulted in the loss of $\mathrm{K}$ and $\mathrm{Rb}$ from the bulk rock. The loss of $\mathrm{K}$ and $\mathrm{Rb}$ is characteristic of the subaerial alteration of basalt (e.g., Honnorez, 1981; Frey et al., 1990) and submarine hydrothermal alteration at $>150^{\circ} \mathrm{C}$ (e.g., Seyfried and Bischoff, 1979; Thompson, 1984). However, based on the absence of talc or smectite-vermiculitechlorite minerals, the saponites in the Site 756 lavas probably formed in a low-temperature environment (Morrison and Thompson, 1986). Saponites with very low $\mathrm{K}_{2} \mathrm{O}$ contents form during low-temperature, submarine alteration in an anoxic environment (Morrison and Thompson, 1986). The blue-green color and relatively low bulk-rock $\mathrm{Fe}_{2} \mathrm{O}_{3}$ and $\mathrm{K}_{2} \mathrm{O}$ contents are consistent with this process. A subsequent event, the brown alteration, formed brown interstratified saponite-glauconite, calcite, and Fe-Mn oxides. This is the typical alteration process that has affected the uppermost basalts of the oceanic crust. It occurs at low temperatures and high fluid/rock ratios and results in oxidation and K-enrichment (e.g., Bass, 1976; Honnorez, 1981; Morrison and Thompson, 1986).

It is unlikely that any of the Site 756 lavas retain magmatic abundances of $\mathrm{K}$ and $\mathrm{Rb}$. Moreover, it is necessary to recognize that all elements are mobile under some conditions. For example, Bienvenu et al. (1990) showed that REE and Th were mobilized in some highly altered MORB. Specifically, they found REE loss and $\mathrm{Th}$ gain with ratios such as $\mathrm{La} / \mathrm{Sm}$ and $\mathrm{Th} / \mathrm{Ta}$ changed by up to factors of 1.5 and 2 , respectively; in contrast, abundance ratios involving $\mathrm{Hf}$ and $\mathrm{Ta}$ were unaffected. However, the similar abundances of $\mathrm{P}, \mathrm{Y}, \mathrm{Zr}, \mathrm{Hf}, \mathrm{Nb}, \mathrm{Ta}, \mathrm{Th}$, and REE in the oxidized and reduced parts of lavas from Site 756 (Table 3 ) and the strongly positive correlations of $\mathrm{P}, \mathrm{Y}, \mathrm{Zr}, \mathrm{Hf}, \mathrm{Nb}, \mathrm{Ta}, \mathrm{Th}$, and REE abundances in all Leg 121 lavas (Fig. 7) lead us to conclude that abundances of these elements can be used to infer and constrain magmatic processes.

\section{Site 757}

In Hole $757 \mathrm{C}, 24.95 \mathrm{~m}$ of basalt was recovered from a basement penetration of $48.3 \mathrm{~m}$. Nineteen flow units were recognized, and we have studied 19 samples from 12 of the units (Table 3 and Fig. 8B). Because of oxidized flow tops and abundant large vesicles, these units are also interpreted as subaerial flows. Based on the age of overlying sediments these basement lavas are $>58$ Ma (Shipboard Scientific Party, 1989c). Duncan (this volume) reported an ${ }^{40} \mathrm{Ar} /{ }^{39} \mathrm{Ar}$ age of $\sim 58 \mathrm{Ma}$.

Most lavas forming the upper units in Hole $757 \mathrm{C}$ are unusually plagioclase-phyric basalts with $40 \%-50 \%$ plagioclase megacrysts and glomerocrysts and rare clinopyroxene phenocrysts in a mod- 
erately altered groundmass. The clinopyroxene phenocrysts are typically low-Fe augite (Fs $8 \%-17 \%$, see Appendix B), with clinopyroxenes from flow Units 757C-F1-757C-F13 overlapping with the compositional field for transitional basalts, whereas clinopyroxene compositions from flow Units 757C-F18 and $757 \mathrm{C}-\mathrm{F} 19$ trend into the field defined by tholeiitic basalts (cf. Figs. 5B and 5E). Small $(10 \mu \mathrm{m})$ clinopyroxene inclusions in plagioclase megacrysts are relatively high in $\mathrm{Fe}$ and low in $\mathrm{Ca}$ (Fig. 5B). Within flow Unit 757C-F18, clinopyroxenes are complexly zoned with relatively $\mathrm{Fe}$-rich cores reversely zoned to Fe-poor inner rims and then to Ca-poor outer rims (Fig. 5C). These reversely zoned clinopyroxenes are xenocrysts. These occurrences of early formed, relatively Fe-rich clinopyroxene as phenocryst cores and as inclusions provide evidence that some Hole $757 \mathrm{C}$ lavas represent mixtures. Evidence for mixing with earlier formed, more evolved magma is that melt inclusions in plagioclase megacrysts commonly have $\mathrm{FeO}^{*} / \mathrm{MgO}$ higher than the $\mathrm{FeO}^{*} / \mathrm{MgO}$ of the bulk rocks (see Appendix B).

The plagioclase megacrysts are dominantly calcic, $\mathrm{An}_{86-88}$, with a strongly zoned outer rim, $\sim 0.1 \mathrm{~mm}$, typically zoned to $\mathrm{An}_{70}$ (Fig. 5F) and sporadically zoned to $\mathrm{An}_{30}$. The low orthoclase content of the plagioclase cores (generally $<2 \%$, see Appendix B) is consistent with crystallization from a tholeiitic melt. The megacrysts are the most calcic plagioclase found in Leg 121 lavas; $\mathrm{An}_{92}$ occurs in one sample. The megacrysts are typically finely oscillatory zoned (Fig. 5F) and contain abundant inclusions (former glass and clinopyroxene). Rapid growth in a repeatedly replenished magma chamber is consistent with these observations. The strong zoning to sodic plagioclase $\left(\mathrm{An}_{30}\right)$ and the occurrence of sodic plagioclase as cavity or fracture fillings is evidence for a Na-rich late-stage magmatic fluid. Segregation vesicles (vesicles filled with late-stage melt) occur in a few samples.

Much of the Hole 757C core is extremely altered with large blebs and amygdules of smectite, zeolite (including analcime and scolecite), and calcite. In particular, flow Units 757C-F11 through $757 \mathrm{C}-\mathrm{F} 17$ are very altered versions of the highly plagioclase-phyric lavas. Although flow Units 757C-F18 and 757C-F19 are geochemically distinctive (e.g., Fig. 7 and following discussion), they are also plagioclase-phyric (2-5-mm plagioclase forming $10-25$ vol\%) with minor to rare clinopyroxene phenocrysts. However, relative to the overlying flow units the mesostasis in flow Units $757 \mathrm{C}-\mathrm{F} 18$ and $757 \mathrm{C}-\mathrm{F} 19$ is richer in plagioclase microlites and poorer in ferromagnesian minerals (Shipboard Scientific Party, 1989c).

In contrast to the lavas from Hole $756 \mathrm{D}$, the major element contents of lavas from Hole $757 \mathrm{C}$ do not define systematic trends (Fig. 6). Some of the geochemical characteristics of the Hole 757C samples obviously reflect the effects of postmagmatic alteration. For example, five samples (121-757C-9R-5, 70-73 cm, 121$757 \mathrm{C}-10 \mathrm{R}-2,66-70 \mathrm{~cm}, 121-757 \mathrm{C}-10 \mathrm{R}-3,2-6 \mathrm{~cm}, 121-757 \mathrm{C}-$ $11 \mathrm{R}-2,51-56 \mathrm{~cm}$, and 121-757C-12R-4, 24-29 cm) have high $\mathrm{H}_{2} \mathrm{O}^{+}(3.8 \%-7.2 \%)$ and high $\mathrm{Fe}_{2} \mathrm{O}_{3} / \mathrm{FeO}(2.9-5.0)$ coupled with unusually high $\mathrm{Na}_{2} \mathrm{O}$ contents $(4.5 \%-5.3 \%)$ and low $\mathrm{CaO}$ contents $(<10 \%)$ (Table 3 and Fig. 6 ). In addition, $30-50 \mathrm{wt} \%$ of these samples was dissolved during acid leaching (Weis and Frey, this volume). Petrographically, the $\mathrm{Na}_{2} \mathrm{O}$ increase and $\mathrm{CaO}$ decrease correspond to several features. In Sample 121-757C-9R-5, 70-73 $\mathrm{cm}$, the plagioclase is largely converted to oligoclase $\left(\mathrm{An}_{22} \mathrm{Or}_{46}\right.$ to $\mathrm{An}_{27} \mathrm{Or}_{5}$ ). In other samples, such as $121-757 \mathrm{C}-11 \mathrm{R}-1,67-72$ $\mathrm{cm}$, the plagioclase megacrysts are replaced by potassium feldspar and albite, and in samples such as those from flow Units 757C-F7 and $757 \mathrm{C}-\mathrm{F} 8$ the high $\mathrm{Na}_{2} \mathrm{O}$ content probably reflects the abundance ( $25 \mathrm{vol} \%)$ of a Na-Ca zeolite. Additional evidence for the mobility of $\mathrm{Ca}$ within the Site 757 cores is the abundant secondary calcite in the lavas and the very high $\mathrm{Ca}$ concentration in the sediment pore waters (Shipboard Scientific Party, 1989c). The latter has been interpreted as resulting from alteration of the $\sim 140$ $\mathrm{m}$ of ash that overlies the basement lavas (Shipboard Scientific Party, 1989c).

Abundances of the incompatible elements LREE, Y, Hf, Ta, and $\mathrm{Th}$ are highly correlated in the Hole $757 \mathrm{C}$ lavas, but $\mathrm{K}$ and $\mathrm{Rb}$ abundances are not correlated with these elements (Fig. 7). In addition, the $\mathrm{K} / \mathrm{Rb}$ ratio, which is not significantly changed by most magmatic processes, ranges widely in the Hole $757 \mathrm{C}$ lavas (Fig. 3), from 258 to 1257 in all the lavas and from 258 to 991 within flow Unit 757C-F5. Macroscopically, the pronounced oxidative/nonoxidative alteration zones reflected by the $\mathrm{K}_{2} \mathrm{O}$-rich, brown saponite-glauconite and the $\mathrm{K}_{2} \mathrm{O}$-poor, green-black saponite, respectively, in the Site 756 basalts occur only in the upper part of the basalt section from Hole $757 \mathrm{C}$. The analyzed samples from flow Unit 757C-F2 contain green-black smectite, and these three samples have relatively low $\mathrm{K}_{2} \mathrm{O}$ and $\mathrm{Rb}$ contents (Table 3 ). In contrast, lavas from flow Units 757C-F3 to 757C-F19 appear to have gained $\mathrm{K}_{2} \mathrm{O}$ and $\mathrm{Rb}$. Specifically, potassium feldspar occurs as an alteration mineral in several samples (see Appendix $A$ ), and the very high $\mathrm{K}_{2} \mathrm{O} / \mathrm{P}_{2} \mathrm{O}_{5}$ ratio ( $\geq 10$ in 16 of 19 samples; Fig. 3) reflects the addition of $\mathrm{K}_{2} \mathrm{O}$ during postmagmatic alteration. Also in Hole $757 \mathrm{C}$, the uppermost lava has the highest $\mathrm{Th} / \mathrm{U}$ ratio, 8.2 in Sample 121-757-9R-1, 105-109 cm, which contrasts with the $\mathrm{Th} / \mathrm{U}$ ratio of $\sim 2$ in flow Units $757 \mathrm{C}-\mathrm{F} 4$ through $757 \mathrm{C}$ F13 (Fig. 11).

Despite the complexities caused by low-temperature processes, many geochemical characteristics of the Hole 757C lavas can be interpreted as a result of magmatic processes. However, the magmatic trends of the Hole $757 \mathrm{C}$ lavas are much more complex than the trends defined by lavas from Hole 756. As discussed previously, some of the scatter in $\mathrm{Na}_{2} \mathrm{O}-\mathrm{MgO}$ and CaO-MgO reflects postmagmatic alteration, but the high $\mathrm{Al}_{2} \mathrm{O}_{3}$ contents (18.4\%-23.9\%, Table 3 and Fig. 6) directly reflect the abundant plagioclase in the Hole $757 \mathrm{C}$ lavas. This correlation of mineralogy and composition is expected in magmas that contain accumulative minerals. That is, a rock formed from a crystallized melt may not have a direct correlation between mineral abundance and lava composition; e.g., depending upon pressure, a melt with a basaltic composition can crystallize as a plagioclase-bearing assemblage (gabbro) or a plagioclase-free assemblage (eclogite). However, addition of a mineral, plagioclase in this case, to a melt establishes a direct correlation between mineral abundance and composition. In contrast to the negative $\mathrm{TiO}_{2}-\mathrm{MgO}$ trend defined by lavas from Site 756 , the positive trend between $\mathrm{TiO}_{2}$ and $\mathrm{MgO}$ in the Hole $757 \mathrm{C}$ lavas (Fig. 6) is consistent with accumulation of plagioclase. Moreover, the wide range in $\mathrm{Sr}$ content (Fig. 7), the negative correlation of $\mathrm{Sr}$ and $\mathrm{CaO} / \mathrm{Al}_{2} \mathrm{O}_{3}$ (Fig. 10), and the trend to very high $\mathrm{Sr} / \mathrm{Nd}$ ratios (Fig. 11) are consistent with plagioclase accumulation. REE abundances in the Hole 757C lavas are also consistent with the accumulation of plagioclase. Specifically, addition of plagioclase to a melt will result in lower REE contents and a positive Eu anomaly. Exactly these characteristics (Fig. 9B) are found in flow Units $757 \mathrm{C}-\mathrm{F} 2$ through $757 \mathrm{C}-\mathrm{F} 13$ (except Sample 121-757C-9R-5, 70-73 cm).

In an effort to document the mobility of plagioclase in the Hole $757 \mathrm{C}$ lavas, a petrographic study of flow Unit 757C-F5 was done aboard ship. Near the upper contact of this $3.8-\mathrm{m}$ flow the proportion of plagioclase phenocrysts is much less $(10 \%-20 \%)$ than in lower parts of the flow, where large plagioclase crystals are abundant, 40-50 vol\% (see Appendix A and Shipboard Scientific Party, 1989c, figs. 15 and 16). Apparently, plagioclase settled within this flow after eruption. A similar variation in plagioclase abundance was observed in other flow units. We studied four samples from flow Unit 757C-F5 in order to evaluate the geochemical evidence for plagioclase accumulation. These included 

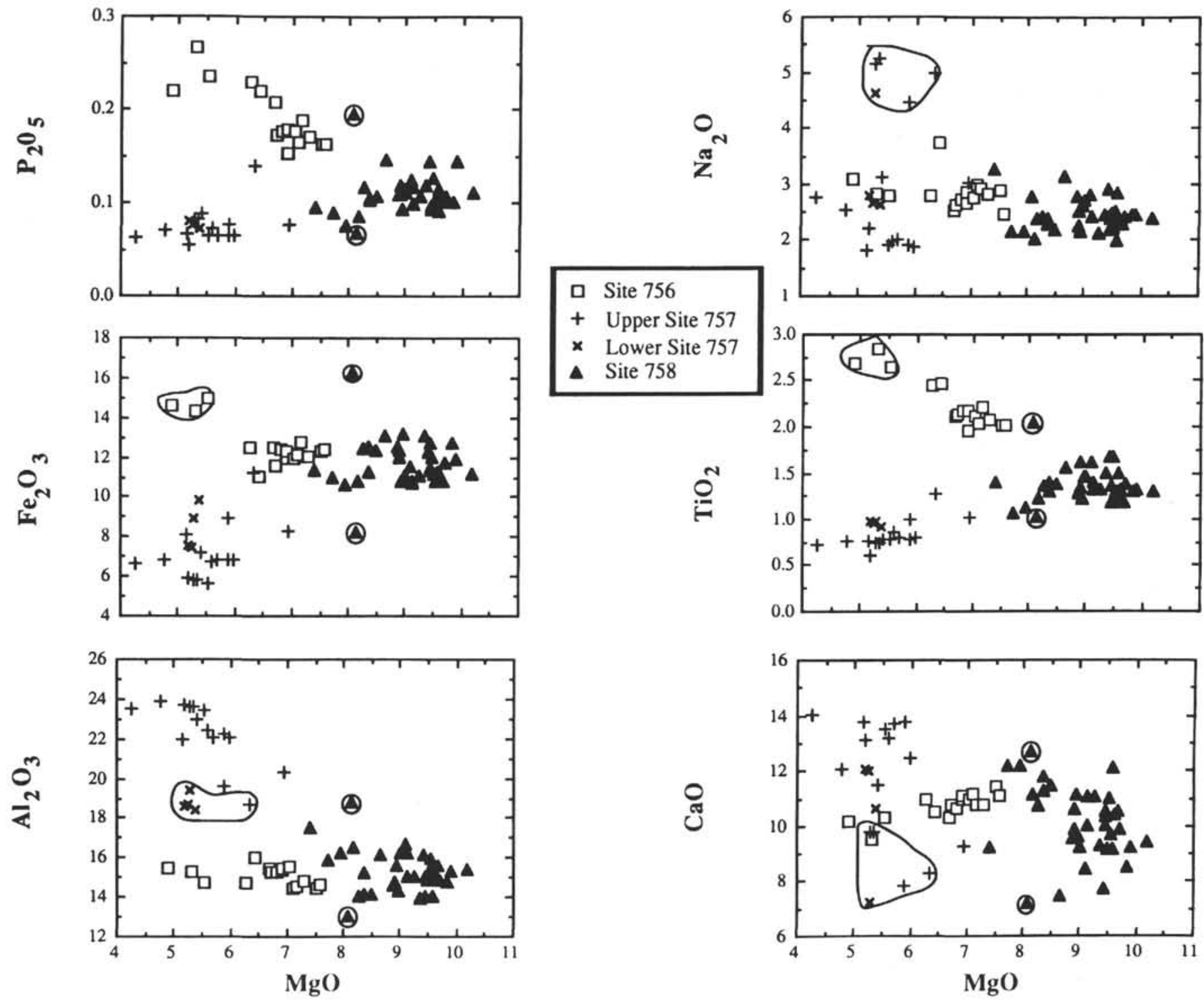

Figure 6. $\mathrm{MgO}$ variation (wt\%) diagrams for Leg 121 lavas. A major feature is that lavas from each site form distinctive compositional groups. In the plots for $\mathrm{P}_{2} \mathrm{O}_{5}, \mathrm{Fe}_{2} \mathrm{O}_{3}$ (all iron as $\mathrm{Fe}_{2} \mathrm{O}_{3}$ ), $\mathrm{Al}_{2} \mathrm{O}_{3}, \mathrm{TiO}_{2}, \mathrm{CaO}, \mathrm{Cr}, \mathrm{Zn}, \mathrm{Ni}$, and $\mathrm{Y}$, the circled uppermost and lowermost triangles define the compositional extremes of lavas from Hole 758A (i.e., Samples 121-758A-58R-6, 21-25 cm, from flow Unit 758A-F2 and 121-758A-62R-1, 130-134 cm, from flow Unit 758A-F4. In the Al $2 \mathrm{O}_{3}$ plot, the circled + and $\times$ symbols indicate the relatively lower $\mathrm{Al}_{2} \mathrm{O}_{3}$ contents in samples from flow Units $757 \mathrm{C}$-F18 and $757 \mathrm{C}$-F19 and the near-contact sample from flow Unit 757C-F5. These are the only Hole $757 \mathrm{C}$ compositions that have not been affected by plagioclase accumulation. In the $\mathrm{Na}_{2} \mathrm{O}$ and $\mathrm{CaO}$ plots, the circled + and $\times$ symbols indicate the five lavas from Hole $757 \mathrm{C}$ that have undergone late-stage $\mathrm{CaO}-\mathrm{Na}_{2} \mathrm{O}$ exchange. In the $\mathrm{TiO}_{2}$ and $\mathrm{Fe}_{2} \mathrm{O}_{3}$ plots the three circled squares indicate the relatively evolved lavas from the upper flow units in Hole 756D. The arrows labeled "plag" in the Ni, La, and Y plots indicate vectors defined by plagioclase addition to the compositions of lavas from flow Units 757C-F18 and 757C-F19. Because the arrows do not intersect the field defined by other lavas from Hole 757C, lavas from flow Units 757C-F18 and 757C-F19 are not parental compositions for the plagioclase-rich Hole 757C lavas, which have higher Ni but lower $\mathrm{La}$ and $\mathrm{Y}$ contents at a similar $\mathrm{MgO}$ content. For comparison, $\mathrm{Ni}$ data for high $\mathrm{MgO}$ lavas from Hawaii (Gunn, 1971) are shown, and the Sc plot shows the field for Kerguelen lavas (solid squares, from D. Weis and F. A. Frey, unpubl. data; Storey et al., 1988). The low Sc contents of most lavas from Hole 757C reflect the dilution effects of cumulate plagioclase. All trace element data plotted on this and subsequent plots are corrected to an anhydrous and oxidized composition.

Sample $121-757 \mathrm{C}-9 \mathrm{R}-5,70-73 \mathrm{~cm}$, which is within $19 \mathrm{~cm}$ of the upper contact, and three other samples distributed throughout this unit in Sections 121-757C-9R-6, 121-757C-9R-7, and 121-757C9R-8; the lowermost sample is $\sim 30 \mathrm{~cm}$ above the lower contact. The sample from near the upper contact has a doleritic texture, relatively small amounts of plagioclase phenocrysts $(2-3 \mathrm{~mm}$ diameter, $\sim 5$ vol\%), and abundant amygdules ( 25 vol\%), with zeolites. In contrast, the other three analyzed samples from flow
Unit $757 \mathrm{C}-\mathrm{F} 5$ contain abundant ( $40-45$ vol\%), 1-5-mm plagioclase phenocrysts. The sample from near the upper contact is highly altered $\left(\mathrm{H}_{2} \mathrm{O}^{+}=7.25 \%\right)$ and has anomalously high $\mathrm{Na}_{2} \mathrm{O}$ and low $\mathrm{CaO}$ contents. These compositional effects result from replacement of groundmass and phenocryst plagioclase by latemagmatic oligoclase $\left(\mathrm{An}_{22} \mathrm{Ab}_{71} \mathrm{Or}_{7}\right.$, see Appendices $\mathrm{A}$ and $\left.\mathrm{B}\right)$ and the formation of zeolites during hydrothermal alteration. In some samples, such as $121-757 \mathrm{C}-9 \mathrm{R}-5,70-73 \mathrm{~cm}$, there is evidence for 

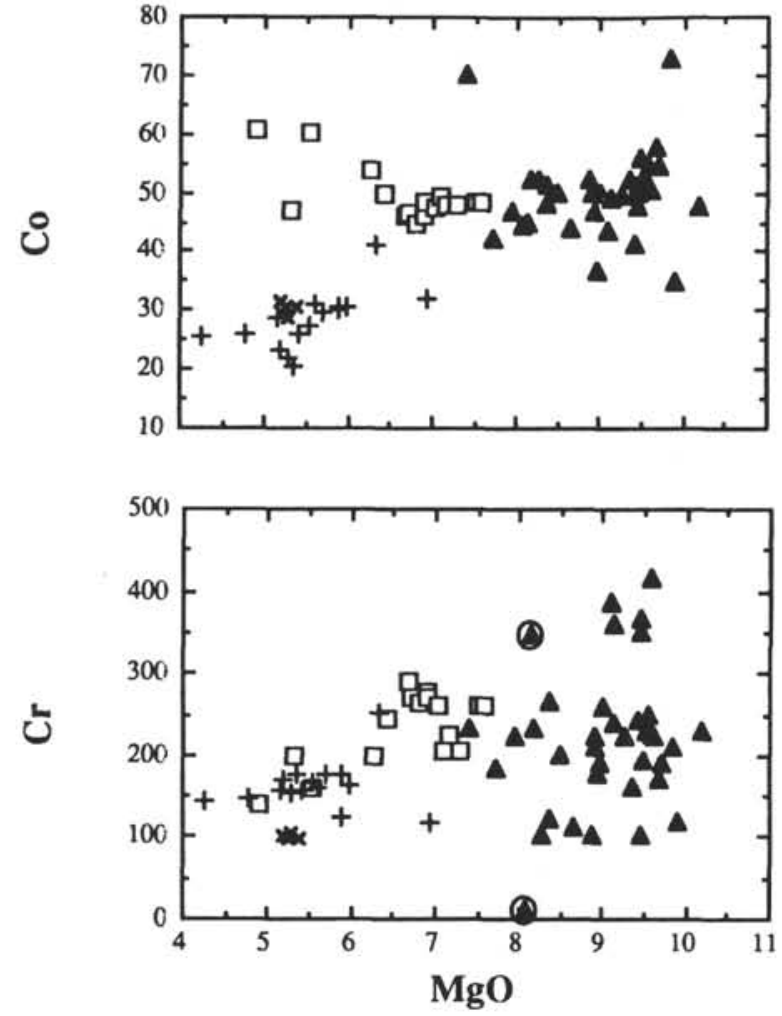

Figure 6 (continued).

a continuum from the final stages of magmatic crystallization to the onset of hydrothermal alteration. Other compositional differences between this near-contact sample and the underlying, plagioclase-rich samples are consistent with plagioclase accumulation. For example, the sample from near the contact has higher abundances of the typically incompatible elements such as P, Y, $\mathrm{Zr}, \mathrm{Hf}, \mathrm{Nb}, \mathrm{Ta}, \mathrm{Th}$, and REE and higher abundances of elements such as $\mathrm{Sc}, \mathrm{Cr}, \mathrm{Co}$, and $\mathrm{Ni}$, which are compatible in mafic minerals (Table 3). Because all of these elements are incompatible in plagioclase, addition of plagioclase lowered the abundances of these elements in the other samples from this flow unit. In addition, Sample 121-757C-9R-5, 70-73 cm, does not have the positive Eu anomaly that is characteristic of other lavas from this part of the core (Fig. 9B). The relatively higher Sr content of Sample $121-757 \mathrm{C}-9 \mathrm{R}-5,70-73 \mathrm{~cm}$, is not consistent with its lower plagioclase content (Table 3 ); however, $\mathrm{Sr}$ can be mobilized in a seawater environment, and we infer that $\mathrm{Sr}$ has been added to this extensively altered, zeolite-bearing sample.
Lavas from the oldest flow units in the hole, 757C-F18 and 757C-F19, have distinctive geochemical and isotopic characteristics. Like the chill zone sample from flow Unit 757C-F5 (121-757C-9R-5, 70-73 cm), lavas from flow Units 757C-F18 and $757 \mathrm{C}-\mathrm{F} 19$ have $<19.5 \% \mathrm{Al}_{2} \mathrm{O}_{3}$ and lack positive $\mathrm{Eu}$ anomalies (Figs. 6 and 9B). However, relative to all other samples from Hole $757 \mathrm{C}$ they have distinctively higher (factors of 2-3) abundances of several incompatible elements (e.g., Fig. 7 plus $\mathrm{La}-\mathrm{MgO}$ and $\mathrm{Y}-\mathrm{MgO}$ plots in Fig. 6) and small but significant differences in several incompatible element abundance ratios; for example, $\mathrm{Th} / \mathrm{La}$ is $\sim 0.15$ in flow Units $757 \mathrm{C}-\mathrm{F} 18$ and $757 \mathrm{C}-\mathrm{F} 19$, but ranges from 0.04 to 0.13 in the overlying units; $\mathrm{Ti} / \mathrm{Eu}$ is $5700-6300$, but $8100-10,400$ in the overlying units; $\mathrm{Hf} / \mathrm{Sm}$ is $0.93-1.05$, but $0.53-0.84$ in the overlying units; and $T h / U$ is $3.3-5.1$, but $\sim 2$ in the overlying units (Fig. 11). Despite higher abundances of most incompatible elements in flow Units $757 \mathrm{C}-\mathrm{F} 18$ and $757 \mathrm{C}-\mathrm{F} 19$, lavas from these units do not have higher abundances of $\mathrm{P}_{2} \mathrm{O}_{5}$ and $\mathrm{TiO}_{2}$ than the overlying lavas (Table 3 and Fig. 6). As a result, 

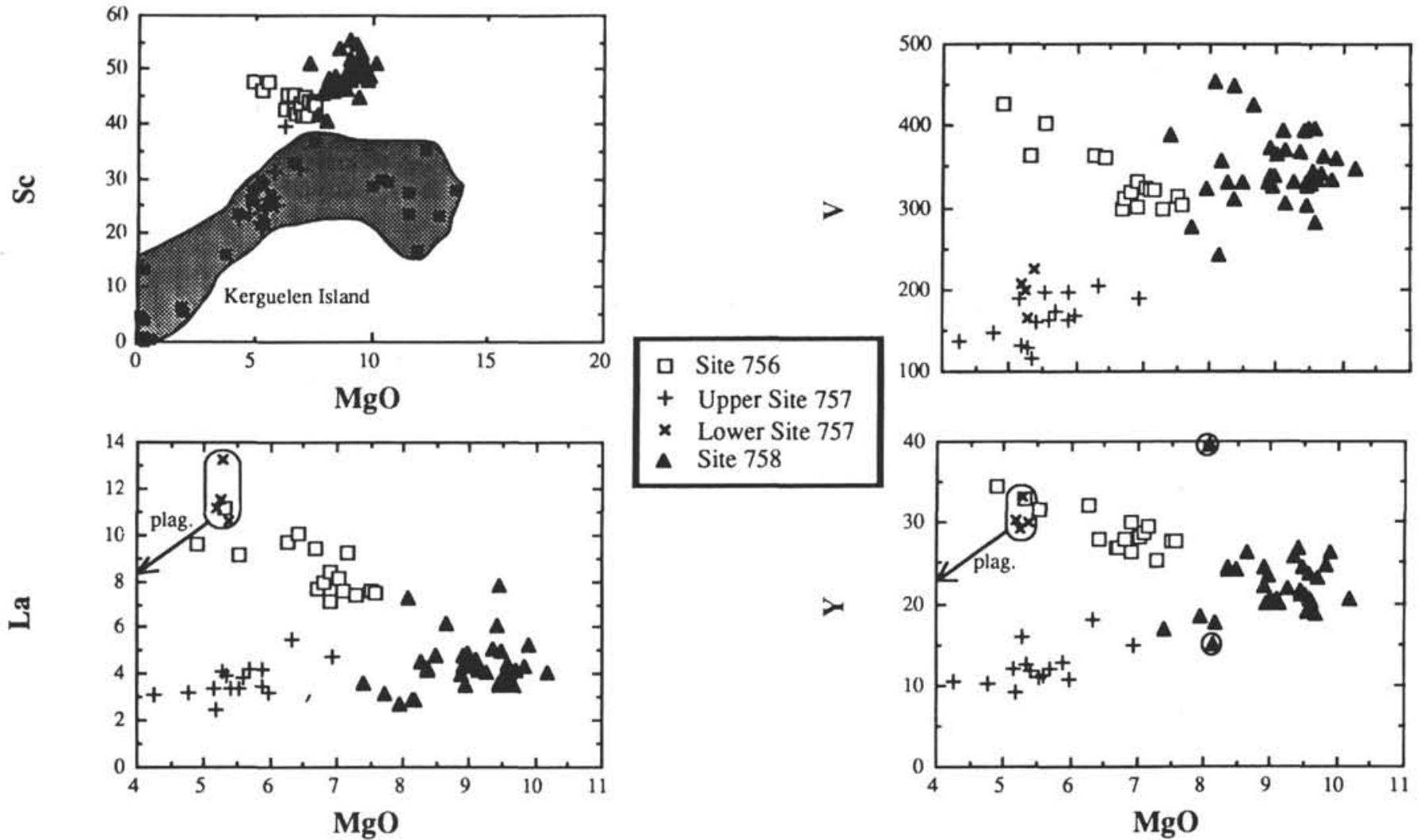

Figure 6 (continued)

lavas from flow Units 757C-F18 and 757C-F19 have much lower $\mathrm{Ti} / \mathrm{Eu}$ and $\mathrm{P} / \mathrm{Nd}$ than the other Hole $757 \mathrm{C}$ lavas (Fig. 11). The $\mathrm{P} / \mathrm{Nd}$ ratios (20-24) in flow Units 757C-F18 and 757C-F19 are anomalously low relative to ratios in most oceanic basalts $(74 \pm$ 13, Sun and McDonough, 1989). Although anomalously low $\mathrm{Ti} / \mathrm{Eu}$ and $\mathrm{P} / \mathrm{Nd}$ ratios may reflect titanomagnetite and apatite segregation, respectively, there is no evidence in their petrography that lavas from flow Units 757C-F18 and 757C-F19 experienced recent apatite or titanomagnetite segregation. In fact, lavas from these flow units are crowded plagioclase porphyries, petrographically similar to the overlying flow units. However, clinopyroxenes in flow Units 757C-F18 and 757C-F19 define different compositional trends (Figs. 5B and 5C).

In addition to differences in abundances of incompatible elements, lavas from flow Units 757C-F18 and 757C-F19 plus samples from flow Units 757C-F8, 757C-F13, and 757C-F14 define a $\mathrm{Ni}-\mathrm{MgO}$ trend that is distinct from the other Hole $757 \mathrm{C}$ lavas (Fig. 6). Samples from flow Units 757C-F18 and 757C-F19 have relatively low $\mathrm{Ni}$ and $\mathrm{Cr}$ contents (Fig. 6) indicating that they may have segregated larger amounts of mafic minerals than the other flow units in Hole 757C. However, their V contents are relatively high (Fig. 6) indicating that the relatively low $\mathrm{TiO}_{2}$ contents of flow Units 757C-F18 and 757C-F19 did not result from extensive segregation of titanomagnetite (e.g., compare with the hawaiites discussed by Frey et al., 1990).

Given their very high $\mathrm{Al}_{2} \mathrm{O}_{3}$ contents, it is conceivable that plagioclase-phyric lavas from flow Units 757C-F2-757C-F13 are mixtures of accumulated plagioclase and melts represented by the compositions of flow Units 757C-F18 and 757C-F19. However, the compositional data show conclusively that lavas in the upper Units 757C-F2 through 757C-F13 are not related to lavas in flow Units 757C-F18 and 757C-F19. There are several reasons for this conclusion. First, the clinopyroxene compositions in flow Units
757C-F18 and 757C-F19 define distinctly different trends (cf. Figs. 5B and 5C). Second, plagioclase phenocrysts form less than $50 \%$ of the lavas, and thus addition of plagioclase cannot explain the depletion, by more than a factor of 2 , of incompatible elements in flow Units 757C-F2-757C-F13 relative to flow Units 757CF18-757C-F19 (Fig. 7). Third, plagioclase addition cannot significantly account for differences in incompatible element abundance ratios such as $\mathrm{Ti} / \mathrm{Eu}, \mathrm{P} / \mathrm{Nd}, \mathrm{Th} / \mathrm{La}, \mathrm{Th} / \mathrm{U}$, and $\mathrm{Hf} / \mathrm{Sm}$ (Fig. 11). Moreover, the lavas with positive Eu anomalies have lower $\mathrm{La} / \mathrm{Sm}$ than lavas from flow Units 757C-F18 and 757C-F19 (Fig. 12), although plagioclase addition would create the opposite trend. Finally, in plots such as $\mathrm{La}-\mathrm{MgO}$ and $\mathrm{Ni}-\mathrm{MgO}$ (Fig. 6), plagioclase addition must establish a trajectory toward the origin, because plagioclase contains insignificant amounts of $\mathrm{La}, \mathrm{Ni}$, and $\mathrm{MgO}$. Because a plagioclase addition trend to lavas in flow Units $757 \mathrm{C}-\mathrm{F} 18$ and 757C-F19 does not intersect the field defined by the overlying plagioclase-phyric lavas (Fig. 6), the lowermost lavas in this core were derived from a distinctly different parental composition. This inference is consistent with isotopic data; specifically, flow Units 757C-F18 and 757C-F19 have slightly lower initial $206 \mathrm{~Pb} / 204 \mathrm{~Pb}$, and ${ }^{207} \mathrm{~Pb} / 204 \mathrm{~Pb}$ than samples from the overlying flow units (Weis and Frey, this volume).

In summary, samples from flow Unit 757C-F5 clearly indicate that plagioclase segregation occurred within this flow. However, the ubiquity of lavas with high $\mathrm{Al}_{2} \mathrm{O}_{3}$ and $\mathrm{Sr}$ contents and positive $\mathrm{Eu}$ anomalies in most of this core require that melt-plagioclase segregation processes also occurred prior to or during eruption. Based on incompatible element abundances, the Hole 757C lavas formed from two compositionally distinct magmas. The uppermost units are related to a melt that is best represented by nearcontact Sample 121-757C-9R-5, 70-73 cm, in flow Unit 757C-F5, and this parental composition is distinct from the parental melt for flow Units 757C-F18 and 757C-F19. The lavas of flow Units 
757C-F18 and 757C-F19 either originated from a source with anomalous composition/mineralogy or they were affected by unusual postmelting processes that created anomalously low $\mathrm{P} / \mathrm{Nd}$, $\mathrm{Ti} / \mathrm{Eu}$, and $\mathrm{Ti} / \mathrm{Zr}$ (Fig. 11).

Both of the compositionally distinct parental magmas represented by Sample 121-757C-9R-5, 70-73 cm, and lavas from flow Units $757 \mathrm{C}$-F18 and $757 \mathrm{C}$-F19 had unusually high $\mathrm{Al}_{2} \mathrm{O}_{3}$ contents $(18 \%-19 \%)$ and relatively low total iron contents (Table 3 and Fig. 6). The aluminous nature of the parental magmas accounts in part for the high abundance of plagioclase and probably a low melt density, which enabled the calcic plagioclase to segregate. Unfortunately, the altered nature of these lavas precludes using their compositions to infer melt density. What is the origin of the anomalously high $\mathrm{Al}_{2} \mathrm{O}_{3}$ contents, low total iron contents, and less than chondritic $\mathrm{CaO} / \mathrm{Al}_{2} \mathrm{O}_{3}$ ratios (Fig. 10)? Because of their evolved compositions $(4 \%-7 \% \mathrm{MgO}$ and $\sim 60 \mathrm{ppm} \mathrm{Ni}$, Table 3 ), the high abundance of $\mathrm{Al}_{2} \mathrm{O}_{3}$ may reflect the absence of plagioclase crystallization during postmelting evolution of these magmas. Alternatively, experimental studies (e.g., Falloon and Green, 1988) have shown that partial melts of peridotite formed at low mantle pressures (e.g., $10 \mathrm{~kb}$ ) and low degrees of melting are characterized by high $\mathrm{Al}_{2} \mathrm{O}_{3}(>19 \%)$ combined with low total iron and $\mathrm{CaO}(<9 \%)$ contents. Therefore, another plausible explanation is that the parental melts for the Hole $757 \mathrm{C}$ lavas formed at atypically low mean pressures, perhaps in a region of unusually thin crust (Klein and Langmuir, 1987). In any event, it is evident that these Hole 757C lavas followed a very different petrogenetic path than the lavas erupted at Sites 756 and 758.

\section{Site 758}

Site 758 is the northernmost drill site on Ninetyeast Ridge (Fig. 1 ), and the recovered basalts are the oldest lavas recovered from the ridge. Based on the age of the overlying sediments the lavas are $>80 \mathrm{Ma}$ (Shipboard Scientific Party, 1989d). Duncan (this volume) reported an ${ }^{40} \mathrm{Ar} /{ }^{39} \mathrm{Ar}$ age of $\sim 81-83 \mathrm{Ma}$. From a total basement penetration of $177.9 \mathrm{~m}, 118.54 \mathrm{~m}$ of basalt was recovered in Hole 758A. Twenty-nine flow units are recognized, with thicknesses ranging from 2 to $>20 \mathrm{~m}$ (Fig. 8C). The uppermost flows are very thick and may represent ponded flows, whereas the lower flows are thin sheet flows and pillow basalts. In contrast to the basalts from Sites 756 and 757, the flows at Site 758 are submarine eruptives. This conclusion is obvious for the pillow basalts and an inference for the thick upper flows (Shipboard Scientific Party, 1989d).

Most samples from Hole 758A are aphyric to sparsely plagioclase-phyric or plagioclase-clinopyroxene-glomerophyric. They are moderately altered, holocrystalline basalts, typically with a doleritic texture. They contain disseminated sulfides and intersertal smectite replaces microcrystalline or possibly glassy mesostasis. Zeolites occupy shrinkage cracks in the smectite. There are two types of sulfides representing different parageneses. Equant grains of pyrite and chalcopyrite, some as large as $2 \mathrm{~mm}$, occur in veinlets with calcite and smectite and as fine grains disseminated in the basalt groundmass. These grains contain no detectable $\mathrm{Ni}$ or Co. In contrast, small corroded grains (up to $10 \mu \mathrm{m}$ ) of chalcopyrite with $2 \%-3 \%$ of both $\mathrm{Ni}$ and $\mathrm{Co}$ and grains of mixed sulfides with approximately equal molar proportions of $\mathrm{Cu}, \mathrm{Fe}$, $\mathrm{Ni}$, and $\mathrm{Co}$ (chalcopyrite-millerite-linnaeite mixtures?) occur disseminated in many samples, always associated with smectite \pm Ti-magnetite (e.g., Sample 121-758A-59R-2, 58-62 cm, see Appendix A). The sulfides with significant $\mathrm{Ni}$ and $\mathrm{Co}$ content are almost certainly of magmatic origin (e.g., see review by Morrison and Thompson, 1986). However, the Ni- and Co-poor sulfides are in equilibrium with the alteration minerals, calcite and smectite. These sulfides formed during hydrothermal alteration at low to moderate temperatures. In part, they may have replaced magmatic sulfides.
Thirty-eight lavas from Hole 758A were analyzed, including several samples from each of the massive flow units at the top of the core (Table 3). On an anhydrous and oxidized basis these lavas span a very narrow range in $\mathrm{SiO}_{2}$ content (49.04\% to $50.04 \%$ ). Although they lie close to the tholeiitic boundary in a $\mathrm{FeO}^{*} / \mathrm{MgO}$ $\mathrm{SiO}_{2}$ plot, they are clearly tholeiitic in the total alkalis- $\mathrm{SiO}_{2}$ plot (Fig. 4). Also, the cores of the clinopyroxene phenocrysts are $\mathrm{Fe}$-poor augite with rims and groundmass compositions that define a transitional to tholeiitic trend (Fig. 5D). In contrast to the Hole $757 \mathrm{C}$ lavas, none of the Hole $758 \mathrm{~A}$ lavas have very high $\mathrm{H}_{2} \mathrm{O}^{+}$or anomalously high $\mathrm{Na}_{2} \mathrm{O}$ contents. However, $\mathrm{H}_{2} \mathrm{O}^{-}$contents in the Hole $758 \mathrm{~A}$ lavas are high, ranging from $0.92 \%$ to $4.06 \%$ (Fig. 3). Thus $\mathrm{H}_{2} \mathrm{O}^{-} / \mathrm{H}_{2} \mathrm{O}^{+}$ratios are $>1$ in the Site 758 lavas, whereas they are typically $<1$ in most lavas from Sites 756 and 757 (Table 3 ). Presumably, the high $\mathrm{H}_{2} \mathrm{O}^{-}$reflects a distinctive type of smectite. These smectites changed from gray-green to brownish in color during sawing of the core. Also, during shipboard study the long continuous cores bowed, as the clays contracted during drying (Shipboard Scientific Party, 1989c).

An important characteristic of the Hole $758 \mathrm{~A}$ lavas is their relatively high $(8 \%-10 \%) \mathrm{MgO}$ content. Consequently, they do not overlap in $\mathrm{MgO}$ variation diagrams with lavas from Holes 756 and 757 (Fig. 6). However, the Hole 758A lavas do not define coherent trends similar to liquid lines of descent resulting from basaltic melt-mineral segregation; for example, the $\mathrm{TiO}_{2}-\mathrm{MgO}$ trend is essentially horizontal (Fig. 6), and neither the Ni contents (Fig. 6) nor the wide range in $\mathrm{CaO} / \mathrm{Al}_{2} \mathrm{O}_{3}(0.48-0.87)$ is correlated with $\mathrm{MgO}$ content (Fig. 10). The surprisingly low Ni contents of lavas with $9 \%-10 \% \mathrm{MgO}$ (cf. Hawaiian trend in Fig. 6) may reflect an earlier history of olivine fractionation, derivation from an olivine and $\mathrm{Ni}$-poor source such as pyroxenite, or postmagmatic alteration of $\mathrm{MgO}$ and/or Ni contents.

Two samples form the compositional extremes of the Hole 758A lavas (Table 3). Sample 121-758A-58R-6, 21-25 cm, from the interior of flow Unit 758A-F2, has atypically high abundances of $\mathrm{Fe}_{2} \mathrm{O}_{3}, \mathrm{TiO}_{2}, \mathrm{P}_{2} \mathrm{O}_{5}, \mathrm{~V}, \mathrm{Zn}, \mathrm{Y}$, and HREE but relatively low $\mathrm{Al}_{2} \mathrm{O}_{3}, \mathrm{CaO}, \mathrm{Ni}$, and $\mathrm{Cr}$ contents. Sample 121-758A-62R-1, 130 $134 \mathrm{~cm}$, from flow Unit 758A-F4, which has a very similar $\mathrm{MgO}$ content $(\sim 8.1 \%)$, has exactly the opposite compositional characteristics (Figs. 6 and 7). In flow Units 758A-F2 through 758A-F29 these two samples also define the extremes in abundances of many incompatible elements, by about a factor of 2.5 , for REE, Y, Zr, $\mathrm{Hf}, \mathrm{Nb}$, and Th (Table 3 ).

As with the lavas from Sites 756 and $757, \mathrm{~K}_{2} \mathrm{O}$ and $\mathrm{Rb}$ abundances are poorly correlated with abundances of incompatible elements such as P or LREE (Fig. 7). Abundances of $\mathrm{Rb}$ in the Hole $758 \mathrm{~A}$ lavas are generally $<1$ ppm (Table 3 ). $\mathrm{K}_{2} \mathrm{O} / \mathrm{P}_{2} \mathrm{O}_{5}$ is $<1$ in several lavas, including three of the four pillow basalts analyzed. Also, K/Rb ratios range from 510 to 6491 with large variations within single flow units (671-1576 and 510-3189 in flow Units 758A-F1 and 758A-F2, respectively). We interpret the anomalously low $\mathrm{K}$ and $\mathrm{Rb}$ contents and the local large variability in abundance ratios involving $\mathrm{K}$ and $\mathrm{Rb}$ as the result of postmagmatic hydrothermal alteration at temperatures in excess of $150^{\circ} \mathrm{C}$ (Thompson, 1984). This interpretation is consistent with the presence of disseminated and vein pyrite and chalcopyrite.

The remarkable compositional uniformity of the Hole 758A lavas is clearly shown by the uniform La content as a function of depth (Fig. 13). All Hole 758A lavas have nearly horizontal chondrite-normalized patterns, with $(\mathrm{La} / \mathrm{Yb})_{\mathrm{N}}$ from 0.96 to 1.69 , $(\mathrm{La} / \mathrm{Ce})_{\mathrm{N}}<1$, and HREE abundances of $7 \times-12 \times$ chondrites (Fig. 9C). In detail, however, there are significant differences in REE abundances among some of the samples. Most conspicuous is the REE variability within the massive flow units.

Flow Unit 758A-F1 is defined as beginning with the four pieces of basalt recovered in Section 121-758A-54R-CC, but 

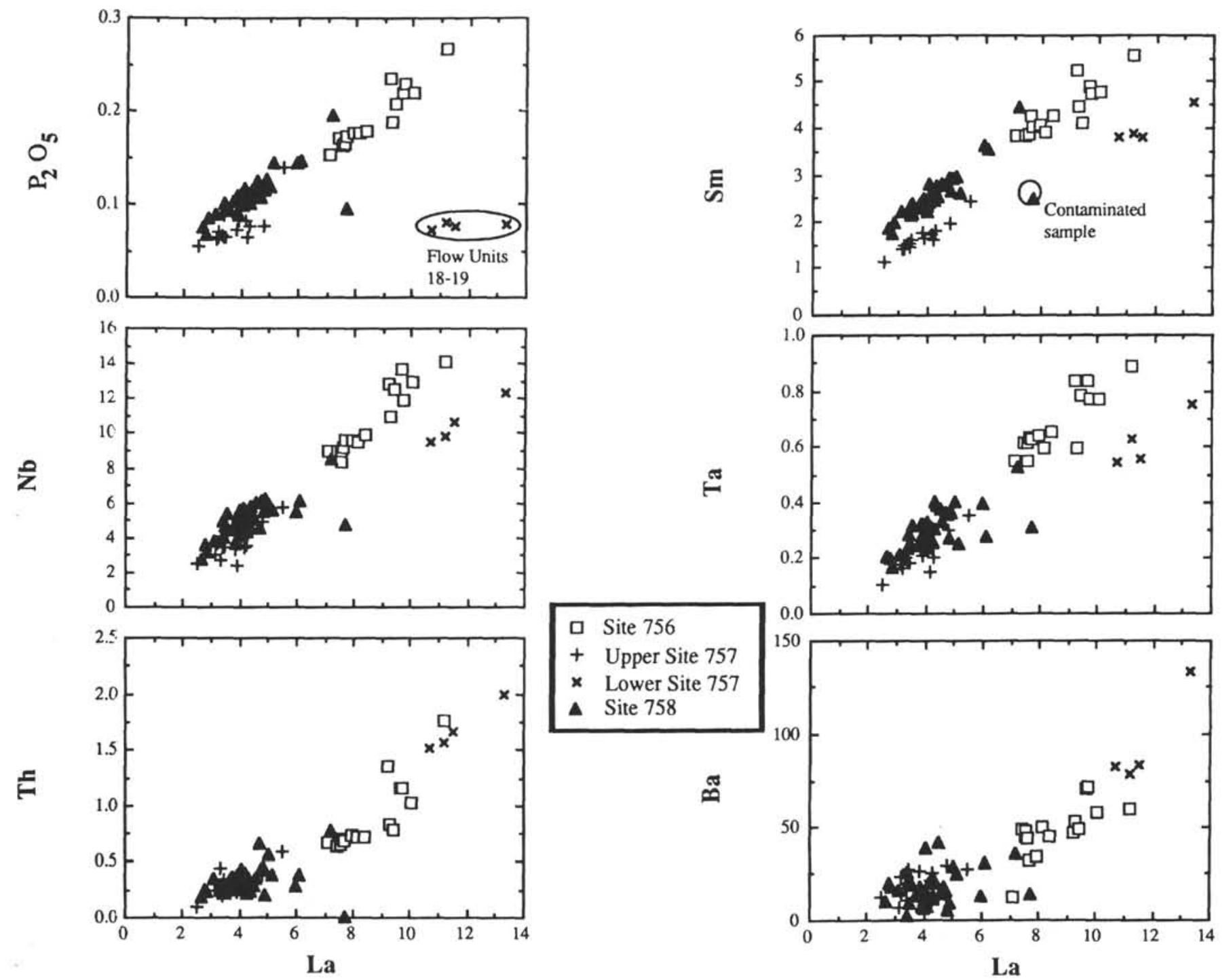

Figure 7. Abundances of incompatible elements in Leg 121 lavas vs. La content (ppm). Abundances of these incompatible elements are positively correlated, except for $\mathrm{Rb}$ and $\mathrm{K}_{2} \mathrm{O}$, which have been markedly affected by postmagmatic processes. Also, $\mathrm{Sr}$ abundances are anomalously high in the plagioclase-rich lavas from Hole 757C. The incompatible element-enriched character of the four samples from flow Units 757C-F18 and 757C-F19 is clearly indicated at $11-13$ ppm $\mathrm{La}$ (e.g., see $\mathrm{P}_{2} \mathrm{O}_{5}$ plot). However, the solid triangle at $7.8 \mathrm{ppm} \mathrm{La}$ is offset from the general trends because this shipboard-prepared sample was contaminated with $\mathrm{La}$ (see Sm plot). As in Figure 6, the extreme compositions (Samples 121-758A-58R-6, 21-25 cm, and 121-758A-62R-1, 130-134 cm) from Site 758 are circled in the Y plot.

several basalt fragments also occur in the overlying Section 121758 A-54R-2, which is composed dominantly of sediments. Sample $121-758 \mathrm{~A}-54 \mathrm{R}-2,73-76 \mathrm{~cm}$, contains $\sim 15 \%$ phenocrysts of plagioclase and glomerocrysts of plagioclase and clinopyroxene in an altered cryptocrystalline to glassy groundmass. Thus, the texture is consistent with a rapidly quenched, near-contact sample (see Appendix A). However, this sample has higher abundances of LREE and lower abundances of $Y$ and HREE than samples from flow Unit 758A-F1 (Table 3 and Fig. 9C). It also has a positive Eu anomaly (Fig. 9C), high $\mathrm{Al}_{2} \mathrm{O}_{3}$ and $\mathrm{Sr}$ contents (Table 3), and a relatively low $\mathrm{CaO} / \mathrm{Al}_{2} \mathrm{O}_{3}$ ratio (Fig. 10 and Table 3 ). These features are consistent with excess plagioclase in this sample, but plagioclase accumulation cannot explain the crossing REE patterns and higher abundances of LREE and other incompatible elements (e.g., $\mathrm{Zr}$ and $\mathrm{Nb}$ ) in this sample. Possibly, Sample 121-758A-54R-2, 73-76 cm, is from a different flow unit. The initial ${ }^{87} \mathrm{Sr} / 86 \mathrm{Sr}$ and ${ }^{206 \mathrm{~Pb}} / 204 \mathrm{~Pb}$ ratios of this sample are slightly higher than those of the two analyzed samples from flow Unit
$758 \mathrm{~A}-\mathrm{F} 1$, but these isotopic differences are not larger than the isotopic heterogeneity found in flow Unit 758A-F2 (Weis and Frey, this volume).

There are also significant compositional variations within flow Unit 758A-F2. As with flow Unit 758A-F1, the uppermost Sample $121-758 \mathrm{~A}-57 \mathrm{R}-3,18-22 \mathrm{~cm}$, which has a texture interpreted as a chill zone (see Appendix A), has a chondrite-normalized pattern that intersects the patterns of other samples from this flow unit (Fig. 9D). Either these chill zone samples reflect independent flow units, or they contain a component introduced during postmagmatic alteration. In the latter case, abundances of LREE, $\mathrm{Zr}$, and $\mathrm{Nb}$ have been affected. Another sample in flow Unit 758A-F2, 121-758A-58R-6, 21-25 cm, is markedly enriched in all REE, and this enrichment is consistent with the previously discussed enrichments in $\mathrm{Fe}_{2} \mathrm{O}_{3}, \mathrm{TiO}_{2}, \mathrm{P}_{2} \mathrm{O}_{5}$, and incompatible trace elements. It appears to be an evolved residual melt. In thin section this sample has no unusual petrographic or mineral characteristics, other than ophitic intergrowth of ilmenite and Ti-magnetite with clinopyrox- 

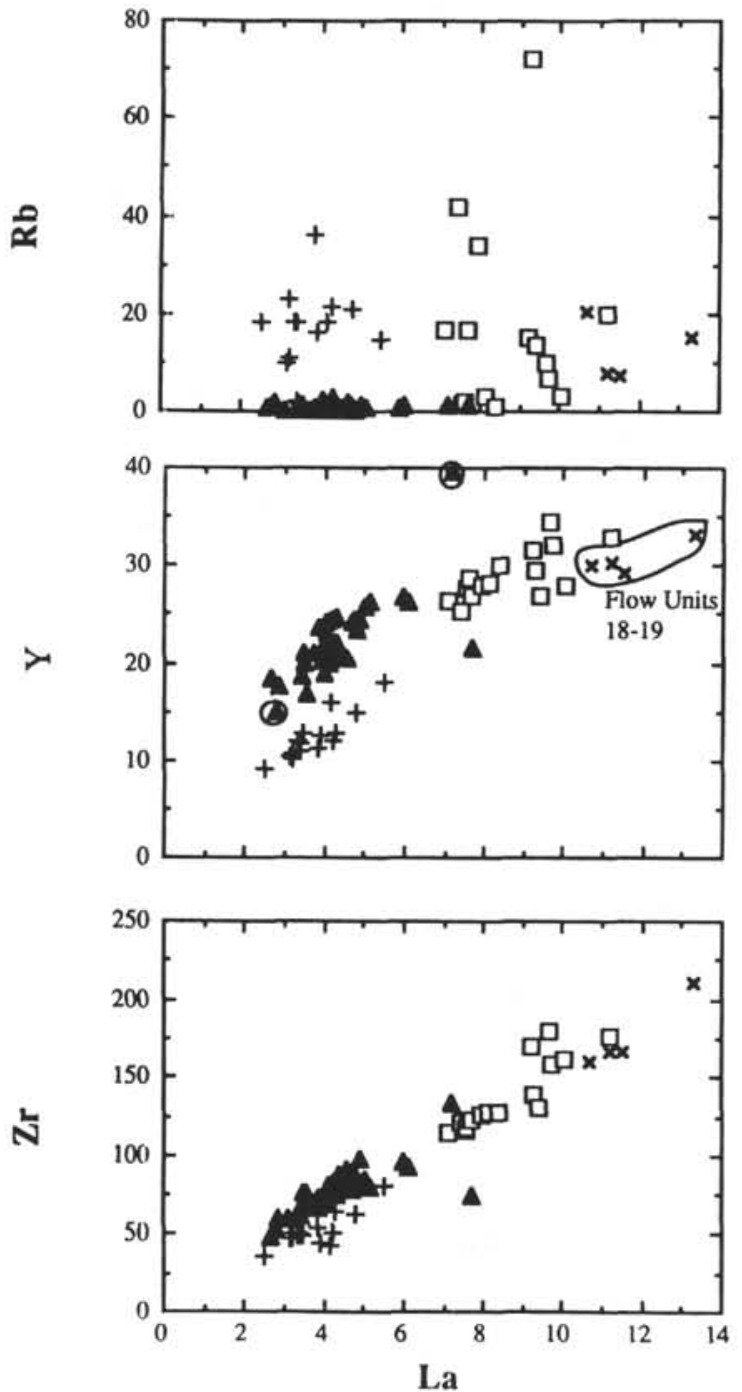

Figure 7 (continued).

ene. However, Sample 121-758A-58R-5, 40-44 cm, which is also from flow Unit 758A-F2, has Fe-rich augite as might be expected in an evolved melt; however, we did not determine the bulk composition of this sample. In contrast to the REE abundance variability in flow Units 758A-F1 and 758A-F2, the three samples from flow Unit 758A-F3, which is also massive $(16.4 \mathrm{~m})$, have very similar REE patterns (Fig. 9C).

As discussed earlier, Sample 121-758A-62R-1, 130-134 cm, from flow Unit 758A-F4 represents an end-member composition. Two other samples from this flow unit (analyzed aboard ship) share the same distinctive features: high $\mathrm{Al}_{2} \mathrm{O}_{3}, \mathrm{Ni}$, and $\mathrm{Cr}$ contents and low abundances of incompatible elements (Shipboard Scientific Party, 1989d). Because Sample 121-758A-62R-1, 130$134 \mathrm{~cm}$, has a positive Eu anomaly (Fig. 9C), and flow Unit 758 A-F4 is highly plagioclase phyric (Shipboard Scientific Party, 1989d), it is evident that samples from this unit have accumulated plagioclase. However, all of the distinctive geochemical characteristics of samples from flow Unit 758A-F4 cannot be explained by plagioclase accumulation. For example, the high $\mathrm{Cr}$ and $\mathrm{Ni}$ contents (Fig. 6; Shipboard Scientific Party, 1989d) are inconsistent with plagioclase accumulation. Moreover, Sample 121-

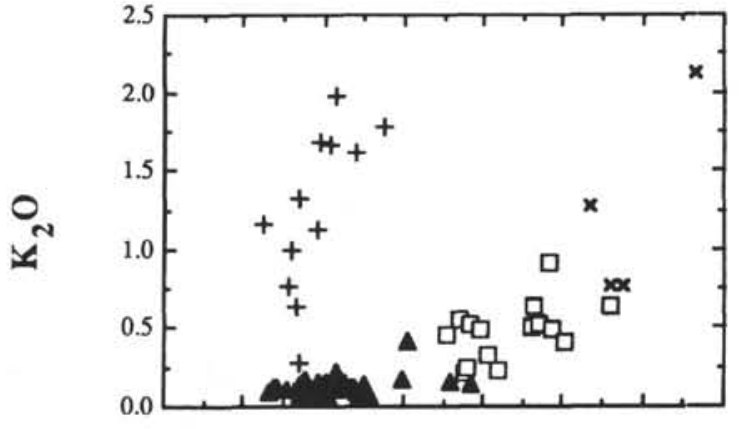

Site 756

+ Upper Site 757

× Lower Site 757 Site 758

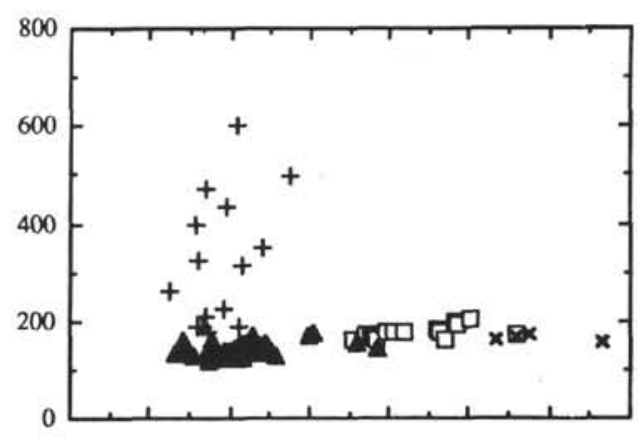

I

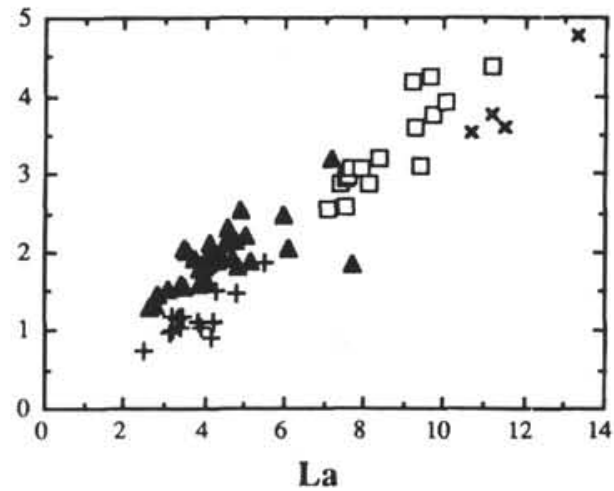

$758 \mathrm{~A}-62 \mathrm{R}-1,130-134 \mathrm{~cm}$, has the highest initial ratio of $206 \mathrm{~Pb} / 204 \mathrm{~Pb}$ found in lavas from Hole $758 \mathrm{~A}$ (Weis and Frey, this volume). Consequently, we infer that flow Unit 758A-F4 was derived from a compositionally and isotopically distinctive parental magma.

The remaining 21 samples from flow Units 758A-F5, 758AF7, 758A-F10, 758A-F13-758A-F15, and 758A-F17-758A-F29 have very similar REE patterns, with $(\mathrm{La} / \mathrm{Yb})_{\mathrm{N}}$ ranging from a low of 1.03 in flow Unit 758A-F13 to a high of 1.60 in Unit 758A-F5 (Figs. 9C and 12). These samples also have isotopic similarities; for example, ${ }^{206 \mathrm{~Pb}} / 204 \mathrm{~Pb}$, an isotopic ratio that is relatively unaffected by postmagmatic submarine alteration but varies significantly in lavas from the Indian Ocean seafloor, varies only from 18.24 to 18.44 in 11 samples from these flow units; also, the acid-leached ${ }^{87} \mathrm{Sr} / 86 \mathrm{Sr}$ ratios in the 18 lavas from Hole $758 \mathrm{~A}$ are remarkably constant, at $0.70438 \pm 0.00009$ (Weis and Frey, this volume). In addition, abundances of the incompatible elements, $\mathrm{P}, \mathrm{LREE}, \mathrm{Zr}, \mathrm{Hf}$, and $\mathrm{Nb}$ are highly correlated in all of the Hole 758A lavas (Fig. 7). The poorer correlations for $\mathrm{Ba}, \mathrm{Ta}$, and $\mathrm{Th}$ reflect poor precision at low abundance levels, and for $\mathrm{K}, \mathrm{Rb}$, and perhaps Sr the poor correlations reflect postmagmatic alteration 
A

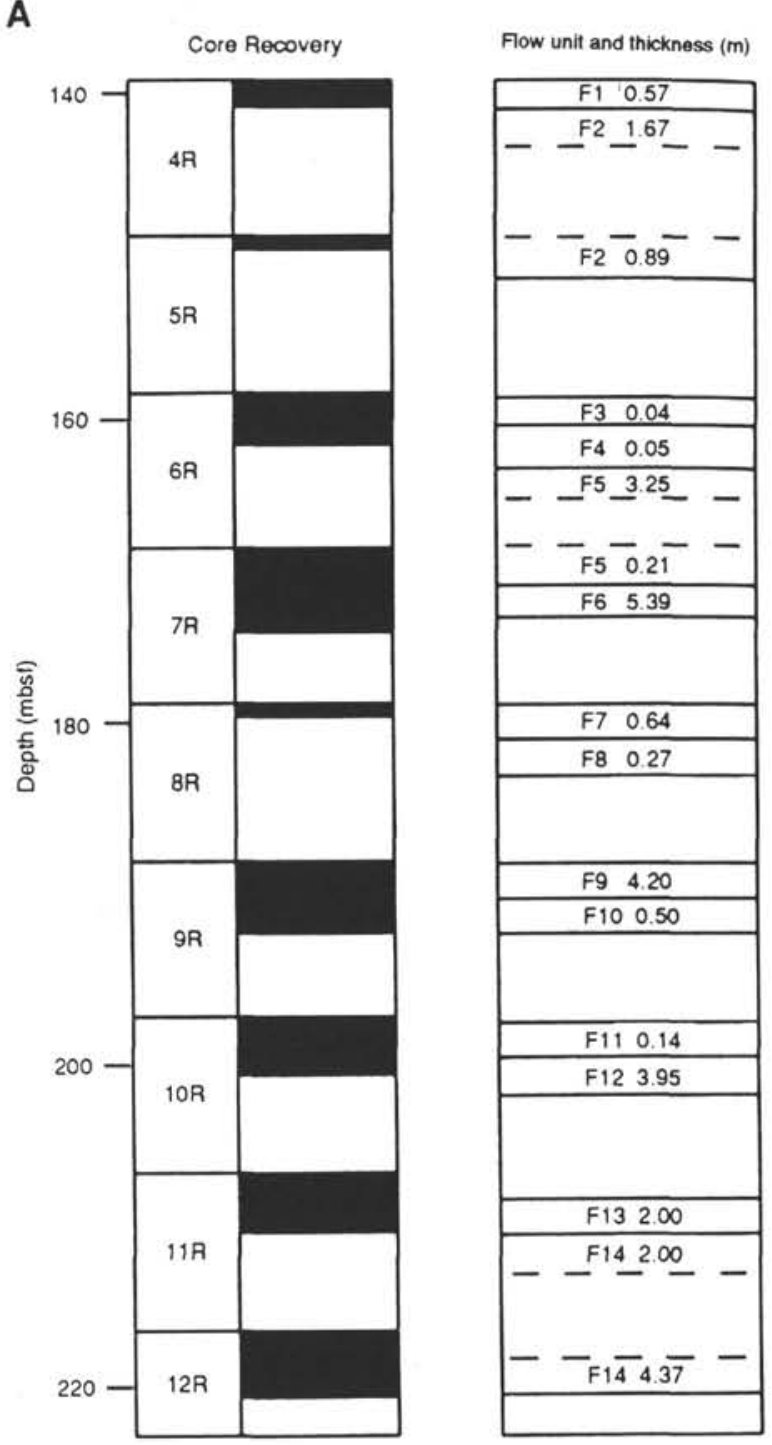

B

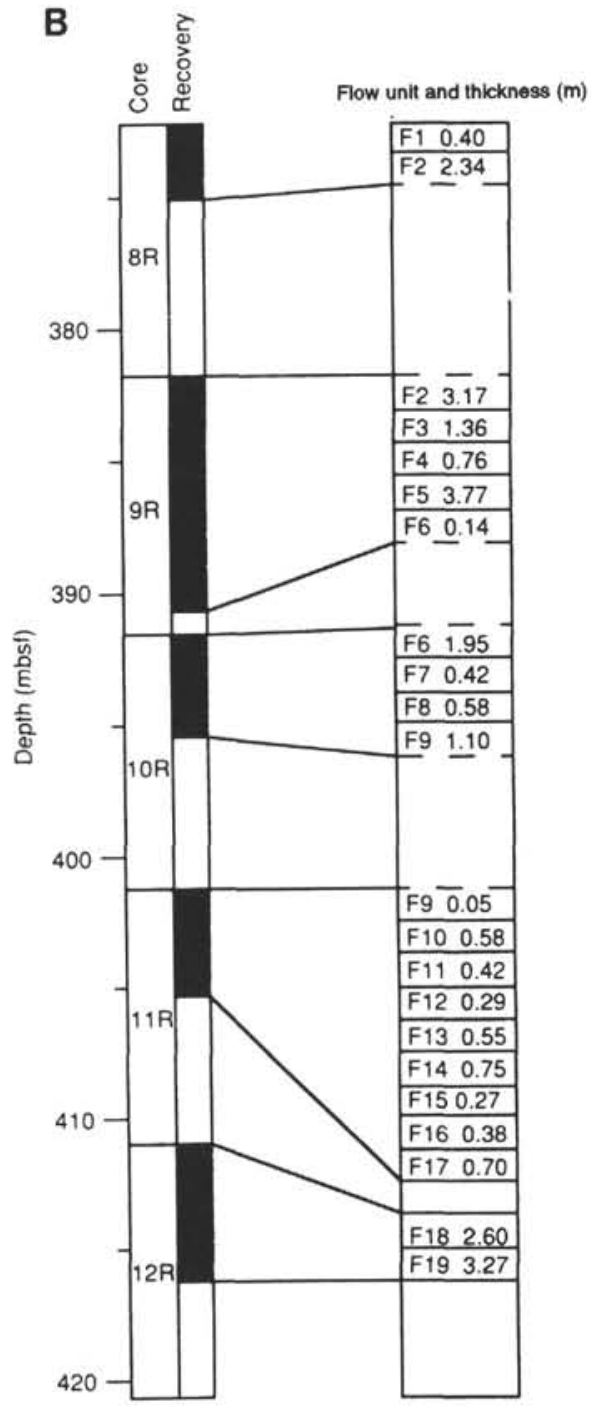

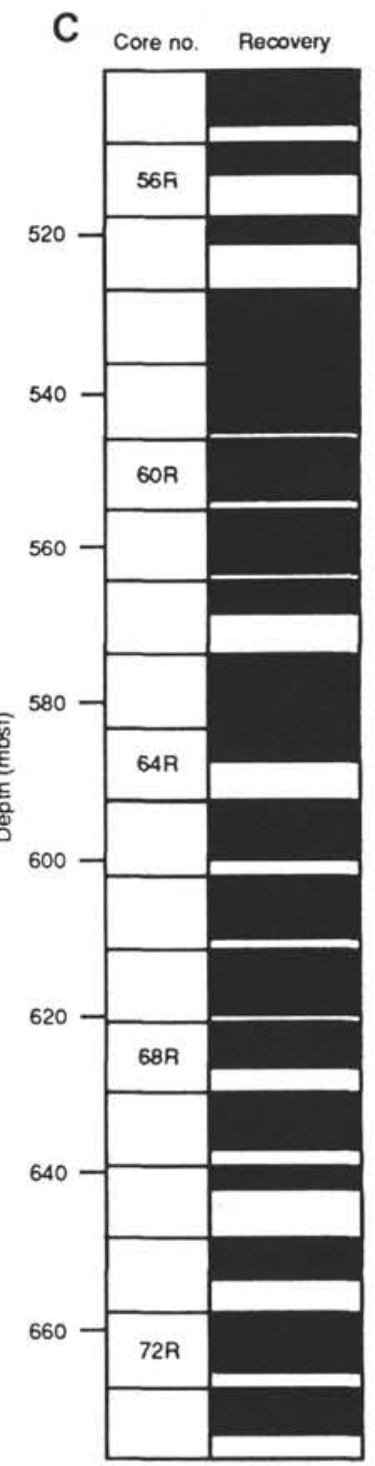

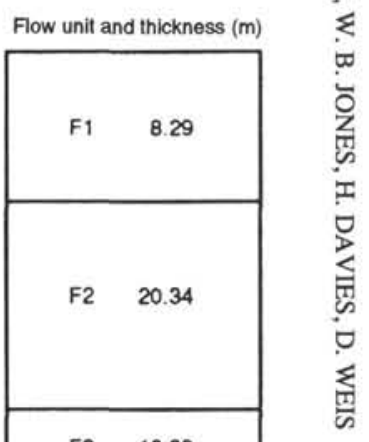

Figure 8. Basement cores, core recovery, and flow unit thickness in meters, defined by the Shipboard Scientific Party (1989b, 1989c, 1989d). A. Hole 756D. B. Hole 757C. C. Hole 758A. 
effects. In addition, $\mathrm{MgO}$ variation diagrams for the major elements and compatible and incompatible trace elements do not define trends consistent with a single liquid line of descent (Fig. 6). These poor trends may in part reflect accumulation of phenocryst phases, but it is also possible that $\mathrm{MgO}$ was mobile during postmagmatic alteration.

In summary, in the Hole $758 \mathrm{~A}$ core there are significant compositional variations within the thick upper flow units and the compositions of some flow units require a compositionally distinct magma. However, the lavas from Hole $758 \mathrm{~A}$ are geochemically distinct from the lavas cored in Holes 756D and 757C; specifically, the Hole $758 \mathrm{~A}$ lavas have lower $\mathrm{La} / \mathrm{P}_{2} \mathrm{O}_{5}, \mathrm{La} / \mathrm{Sm}$, $\mathrm{La} / \mathrm{Y}, \mathrm{La} / \mathrm{Hf}$, and $\mathrm{La} / \mathrm{Yb}$ (Figs. 7 and 12) and different chondritenormalized REE patterns (Fig. 9D). These compositional differences are accompanied by differences in $\mathrm{Sr}, \mathrm{Nd}$, and $\mathrm{Pb}$ isotopes (Weis and Frey, this volume).

\section{DISCUSSION}

\section{Implications of Geochemical Variations at Individual Drill Sites on Ninetyeast Ridge}

Variations in lava compositions as a function of eruption age provide important constraints on the evolution of volcanoes (e.g., Feigenson and Spera, 1981; Chen and Frey, 1985; Frey et al., 1990). Significant penetrations ( $>50 \mathrm{~m}$ ) of igneous basement have been achieved at four drilling sites on Ninetyeast Ridge-Leg 121 Holes 756D, 757C, and 758A and Deep Sea Drilling Project (DSDP) Leg 22 Site 214-and these cores provide information about the waning stage of volcanism forming Ninetyeast Ridge. However, lavas from these four cores define different compositional trends with stratigraphic position. For example, in the Hole $756 \mathrm{D}$ core there is only a modest $(<30 \%)$ increase in La content in the youngest lavas (Table 3 and Fig. 13), and in the Hole 758A core there is no systematic compositional trend with stratigraphic position (Fig. 13). In contrast, in Hole 757C the lowermost flow units are tholeiitic basalts that are relatively enriched in incompatible elements, whereas at Site 214 highly evolved residual melts (oceanic andesites with $\mathrm{La}>30 \mathrm{ppm}, \mathrm{FeO}^{*} / \mathrm{MgO} \sim 4$ ) overlie ferrobasalts (Fig. 13). These different temporal trends at different sites on Ninetyeast Ridge (e.g., Site 214 compared with Site 758) may reflect sampling of the ridge at different volcanic structures. For example, the evolved lavas at Site 214 may reflect cooling and fractionation in a magma chamber associated with a large subaerial volcanic center whereas the nearly uniform compositions of the submarine lavas at Site 758 may reflect less focused volcanism at a location along the ridge that did not develop a subaerial volcano (e.g., analogous to volcanism between islands along the Hawaiian Ridge; see also table 2 of Shipboard Scientific Party, 1989a).

As discussed earlier, at each of the drill sites there is compositional and isotopic evidence for geochemically distinct parental magmas. Specifically, within the Hole $756 \mathrm{D}$ core, flow Unit 756D-F7 is compositionally distinct (Fig. 9A) and has higher $\mathrm{Pb}$ isotopic ratios; within the Hole 757C core, flow Units 757C-F18 and 757C-F19 are compositionally distinct (Figs. 6, 7, and 9B) and they have lower $206 \mathrm{~Pb} / 204 \mathrm{~Pb}$ ratios; and within the Hole $758 \mathrm{~A}$ core, flow Unit 758A-F4 is compositionally distinct (Figs. 6 and 7) and has a higher ${ }^{206} \mathrm{~Pb} / 204 \mathrm{~Pb}$ ratio (Weis and Frey, this volume). Because the compositional differences are correlated with isotopic differences, the different parental magmas at each site reflect differences in type or proportion of source components. However, the different parental magmas within each core also have significant geochemical similarities; for example, all flow units from Hole 756D, including the compositionally and isotopically ( $\mathrm{Sr}$ and $\mathrm{Nd}$ ) distinct flow Unit 756D-F7, have the relatively high ${ }^{206} \mathrm{~Pb} / 204 \mathrm{~Pb}$ that is characteristic of this core (Weis and Frey, this volume); all flow units from Hole $757 \mathrm{C}$, including the compositionally and isotopically distinct flow Units 757C-F18 and 757C-F19, have high $\mathrm{Al}_{2} \mathrm{O}_{3}$ contents (Fig. 6); and all flow units from Hole 758A, including the compositionally and isotopically distinct flow Unit 758A-F4, have the relatively high $\mathrm{MgO}$ contents that are characteristic of lavas from this core (Fig. 6). Therefore, there were important similarities in the petrogenesis of the different parental magmas that are represented within each core. Specifically, the relatively high $206 \mathrm{~Pb} / 204 \mathrm{~Pb}$ ratios in all lavas from Site 756 require an isotopically distinctive source component (Weis and Frey, this volume), the relatively high $\mathrm{Al}_{2} \mathrm{O}_{3}$ and low total iron contents of all the Site 757 lavas may reflect residue-melt segregation at relatively low pressure, and the higher $\mathrm{MgO}$ contents of all of the Site 758 lavas may reflect the absence of a large volcanic edifice with magma reservoirs that enabled extensive melt-solid fractionation.

Because Ninetyeast Ridge probably formed, at least in part, as a hot-spot trace, it is logical to compare the temporal compositional trends in cores from Ninetyeast Ridge with the well-defined temporal compositional changes that occur at Hawaiian volcanoes. As the shield growth stage terminates at Hawaiian volcanoes, the basaltic lavas change from tholeiitic to alkalic. This trend is observed at several subaerial Hawaiian volcanoes and was also found in DSDP Leg 55 drill cores from Suiko and Ojin seamounts on the Emperor Ridge (e.g., Clague and Dalrymple, 1987). Moreover, most mature Hawaiian volcanoes are capped by evolved alkalic lavas with high abundances of incompatible elements (Clague and Dalrymple, 1987). These changes in lava composition are interpreted to result from decreased magma supply. That is, as a Hawaiian volcano moves away from the hot spot, the extent of mantle melting decreases and ascending alkalic basalt magmas stagnate and cool. Mineral-melt segregation then leads to evolved residual liquids with $\mathrm{MgO}$ commonly <4\% (e.g., Clague, 1987; Frey et al., 1990). Alkalic lavas have not been recovered from Ninetyeast Ridge at any of the seven drill sites. Therefore, the waning stage of volcanism on Ninetyeast Ridge was not similar to that typical of Hawaiian volcanoes. If Ninetyeast Ridge represents a hot-spot track, these differences between the Hawaiian and Ninetyeast Ridge volcanoes imply that, unlike for the Hawaiian volcanoes (see fig. 1 of Frey et al., 1990), the magma supply rate did not decrease precipitously as the Ninetyeast Ridge volcanoes moved away from the hot spot. This difference may reflect the proximity of the hot spot and a spreadingridge axis during the formation of Ninetyeast Ridge (Royer et al., this volume).

Another important difference between Hawaiian volcanism and Ninetyeast Ridge volcanism is the abundance of ash that overlies the basement lavas at several sites on Ninetyeast Ridge; for example, $388 \mathrm{~m}$ of altered, vitric volcanic ash at DSDP Leg 27 Site $253,100 \mathrm{~m}$ of interbedded lignite and volcaniclastic material at Leg 22 Site $214,155 \mathrm{~m}$ of volcaniclastic rocks at Site 757 , and $67 \mathrm{~m}$ of volcanic ash at Site 758 . In contrast, ash forms a very minor component of subaerial Hawaiian volcanoes, and a coarse-grained well-sorted sandstone overlies the extensive basalt section at Suiko seamount (Jackson, Koizumi, et al., 1980). The abundant ashes overlying basaltic basement at several sites on Ninetyeast Ridge are interpreted as reflecting shallow-water $(<100 \mathrm{~m})$ to phreatic basaltic volcanism. An important question is whether the ashes formed at a newly emerging volcanic center and were deposited on an older subsiding center or if they are proximal ashes formed during shallow-water basaltic volcanism that kept pace with the subsidence of a dying volcano on the ridge (Dehn et al., 1989). Presumably this question can be answered with detailed physical and chemical studies of these ashes. At this point, the major conclusion is that shallow-water volcanism was much more important on Ninetyeast Ridge than along the Em- 


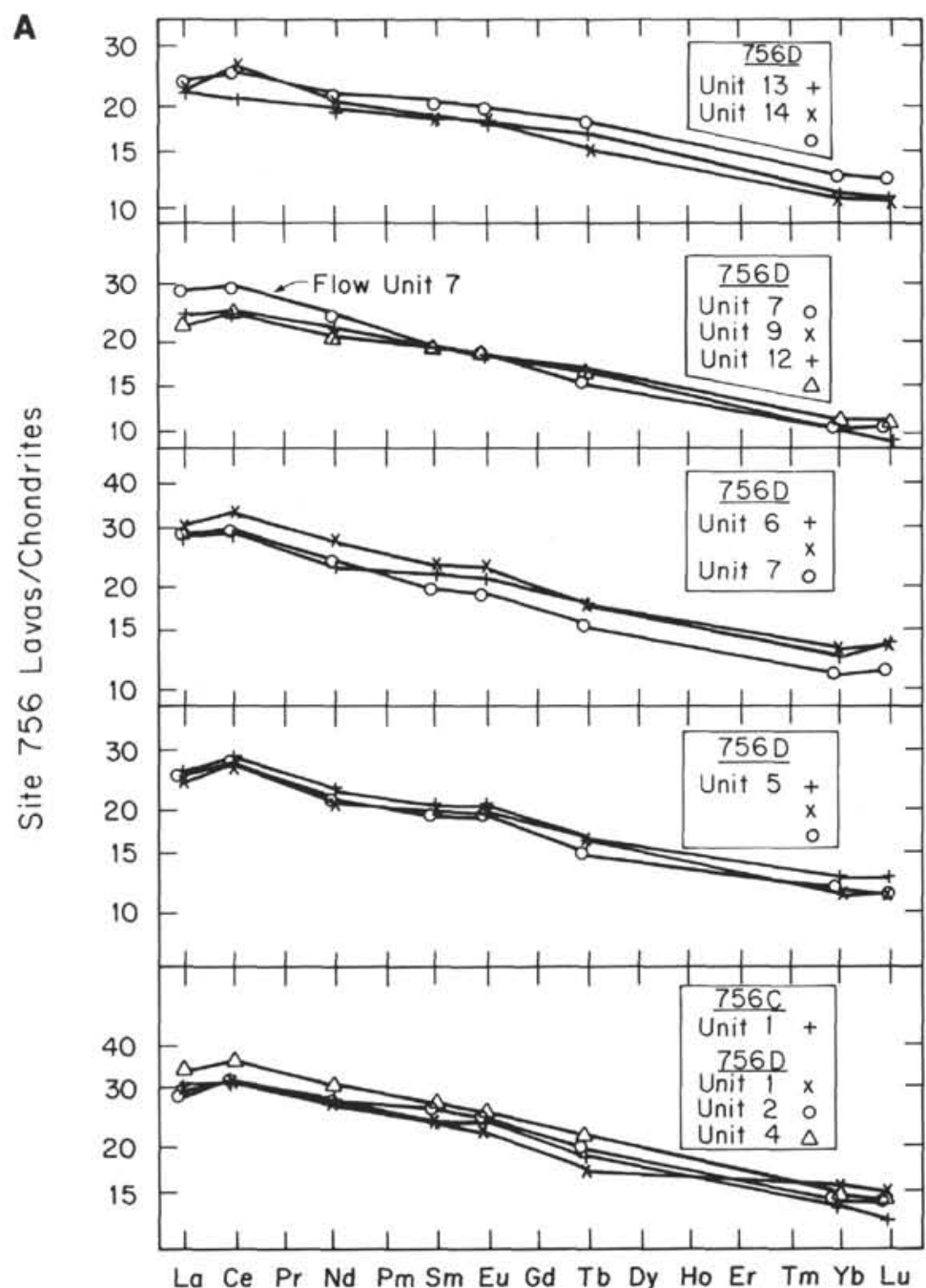

Figure 9. Chondrite-normalized REE data (recommended chondrite values, table 3.3 of Boynton, 1984). A. Lavas from Site 756. Note that the trend for the sample from flow Unit 756D-F7 intersects the trends for flow Units 756D-F9 and 756D-F12. B. Lavas from Hole $757 \mathrm{C}$. Sample $121-757 \mathrm{C}-9 \mathrm{R}-5,70-73 \mathrm{~cm}$, from near the upper contact in flow Unit 757C-F5 and samples from flow Units 757C-F18 and 757C-F19 probably represent melt compositions; all other samples have positive Eu anomalies, and they are plagioclase accumulates. C. Lavas from Hole 758A. The slopes of the patterns are similar except for the sample from flow Unit 758A-F11, which has been contaminated with La (see text). D. Details of REE abundance variations within the thick flow Units 758A-F1 and 758A-F2 (Fig. 8C). Note that in flow Unit 758A-F1, Sample 121-758A-54R-2, $73-76 \mathrm{~cm}$ (solid circles), which may be from the upper chill zone (see Appendix A) has a REE pattern that crosses the other REE patterns; that is, this sample has higher LREE but lower HREE contents. In flow Unit 758A-F2 most of the patterns are subparallel, with Sample 121-758A-58R-6,21-25 cm, significantly enriched in all REE. Apparently, this sample contains an incompatible element-enriched residual melt. As in flow Unit 758A-F1 the upper chill zone Sample 121-758A-57R-3, 18-22 cm (solid circles), has a crossing REE pattern because it has a higher LREE but lower HREE content (except for the highly enriched Sample 121-758A-58R-6, 21-25 cm). The bottom plot is a comparison of Site 756 lavas with the average for Mauna Loa, Hawaii, (Budahn and Schmitt, 1985 ) and a dredged MORB from the Southwest Indian Ridge axis (sample $7 / 1$ from Price et al., 1986). The two center plots are intersite comparisons of Leg 121 lavas. In the top plot, a dredged lava from the Kerguelen Plateau ( 8.04 from Davies et al., 1989) has an REE pattern that is within the field of lavas from Site 756 , but tholeiitic and alkalic basalts from Kerguelen Island (Storey et al., 1988) have a higher LREE/HREE than lavas from Ninetyeast Ridge. Seven transitional Kerguelen basalts have REE abundances that are intermediate between the fields of Kerguelen alkali and tholeiitic basalts (Gautier et al., 1990). 


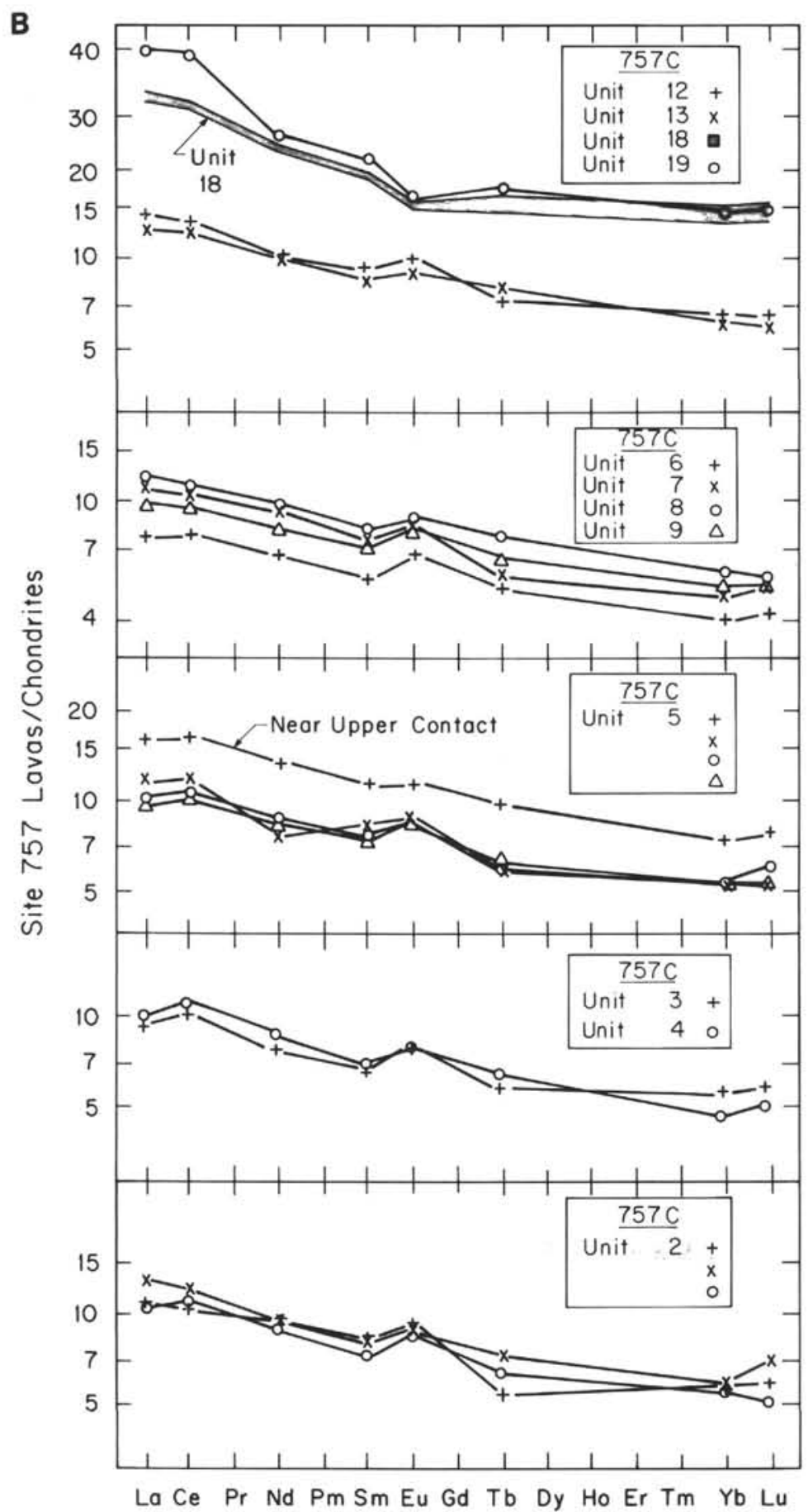

Figure 9 (continued).

peror-Hawaiian ridges. Again, this difference may be explained by the formation of Ninetyeast Ridge near a spreading-ridge axis.

\section{Intersite Comparisons: Geochemical Differences and Similarities}

There is surprisingly little compositional overlap among basement lavas from Sites 756, 757, and 758 (Figs. 6 and 7). Many of the intersite geochemical differences reflect magmatic processes. For example, the Hole 757C lavas provide unambiguous petrographic and geochemical evidence for crustal processes involving segregation and accumulation of plagioclase; specifically, most of the Hole $757 \mathrm{C}$ lavas have very high $\mathrm{Al}_{2} \mathrm{O}_{3}$ contents $(>22 \%$, Fig. 6) and positive Eu anomalies (Fig. 9B). The only lavas from this site with compositions that may reflect crystallized melt compositions (except for abundances modified by postmagmatic alteration processes) are Sample 121-757C-9R-5, 70-73 cm, from near the upper contact of flow Unit 757C-F5 and lavas in the lowermost flow Units 757C-F18 and 757C-F19. In contrast, except for the effects of late-stage alteration, most of the lavas from Holes 756D and 758A may represent melt compositions. There are also important intersite differences in incompatible trace element contents (Fig. 7), abundance ratios (Figs. 11 and 12), and 


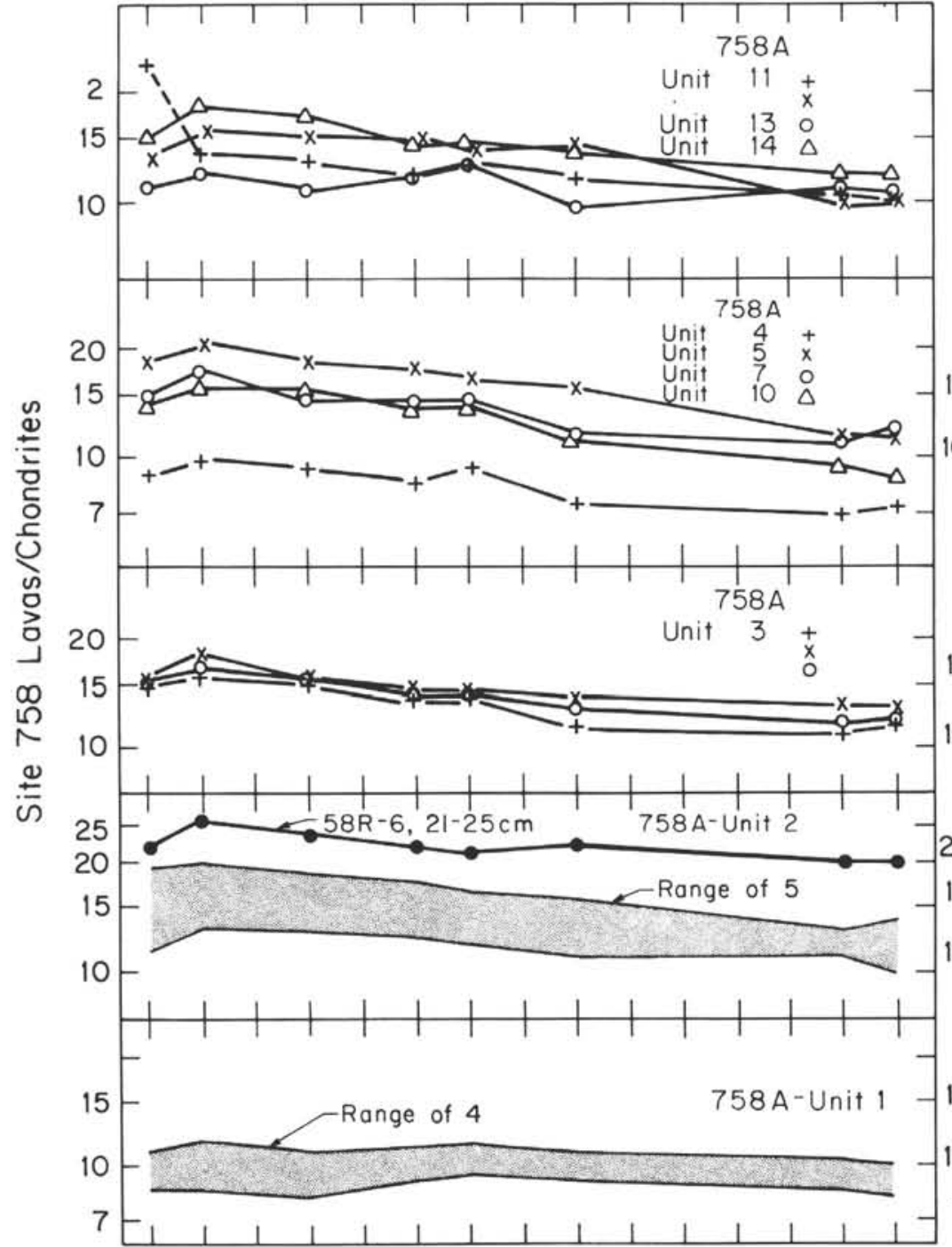

La Ce Pr Nd Pm Sm Eu Gd Tb Dy Ho Er Tm Yb Lu Figure 9 (continued).
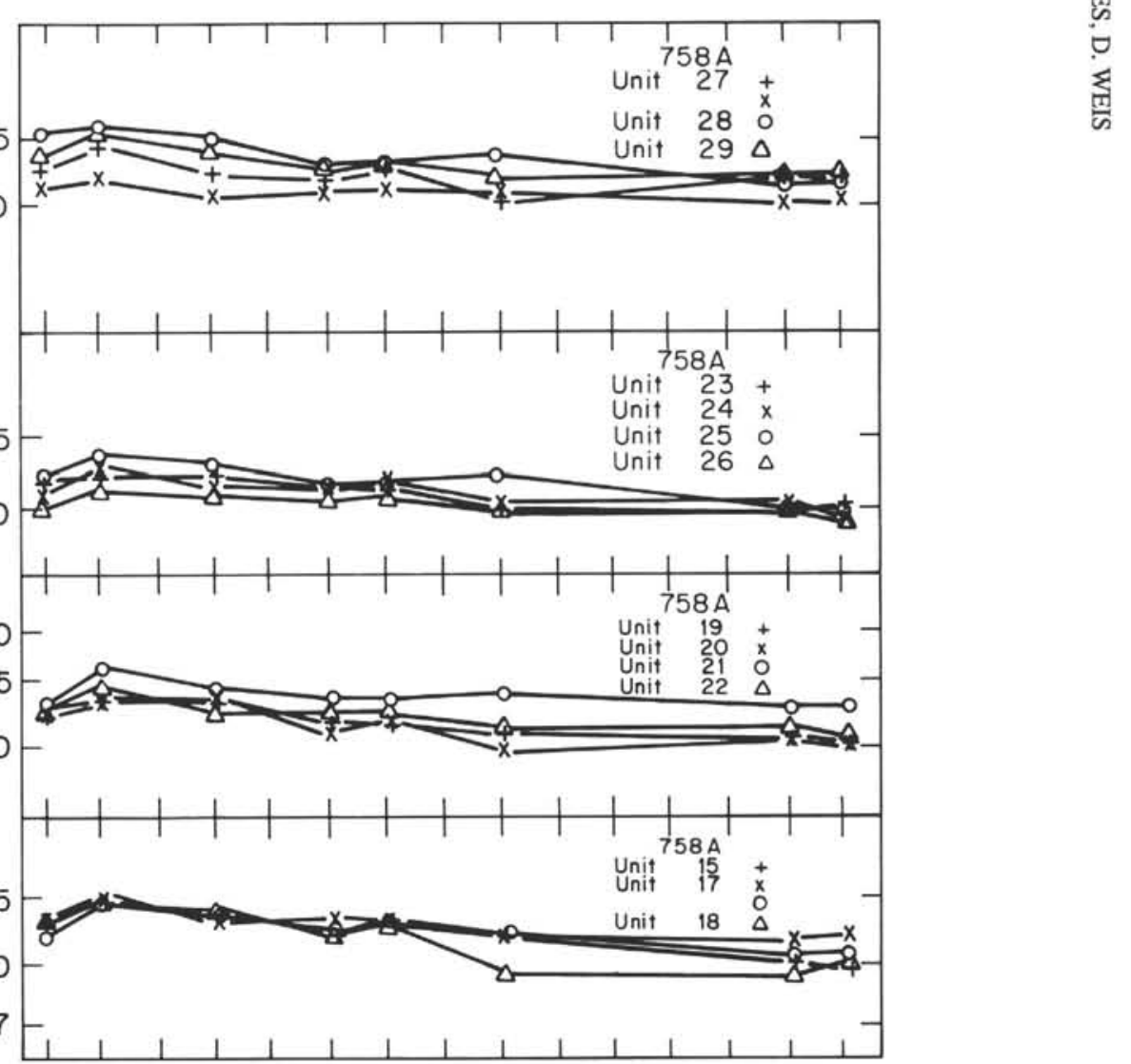

La Ce Pr Nd Pm Sm Eu Gd Tb Dy Ho Er Tm Yb Lu 


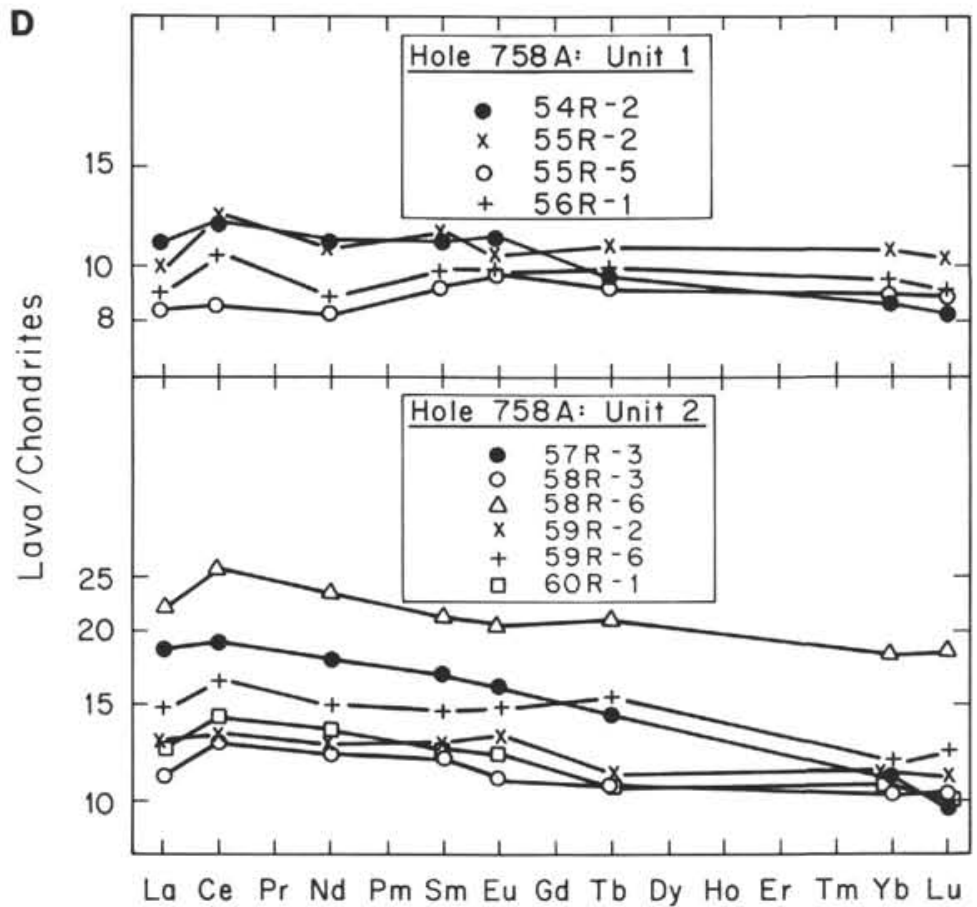

Figure 9 (continued).

initial isotopic ratios of $\mathrm{Sr}, \mathrm{Nd}$, and $\mathrm{Pb}$ (Weis and Frey, this volume). The highest abundances are in lavas from Site 756 and flow Units 757C-F18 and 757C-F19, and the lowest abundances are in the plagioclase-phyric lavas from Hole 757C (Fig. 7). Also, shipboard results show significant intersite differences in $\mathrm{Y} / \mathrm{Nb}$ and $\mathrm{Zr} / \mathrm{Nb}$ (Shipboard Scientific Party, 1989a), and our results confirm that, as a group, lavas from Site 758 trend to higher $\mathrm{Y} / \mathrm{Nb}$ and $\mathrm{Zr} / \mathrm{Nb}$, whereas lavas from Site 756 trend to lower ratios (Fig. 14).

Interpretations of incompatible element abundances in basalts can be discussed in the context of a mantle-normalized diagram (Fig. 15) in which elements are arranged in order of incompatibility as observed in oceanic basalts; for example, $\mathrm{Rb} \sim \mathrm{Ba}>\mathrm{Th}>$ $\mathrm{Nb}=\mathrm{Ta} \sim \mathrm{K}>\mathrm{La}>\mathrm{Ce} \sim \mathrm{Pb}>\mathrm{Sr}>\mathrm{P} \sim \mathrm{Nd}>\mathrm{Zr}=\mathrm{Hf} \sim \mathrm{Sm}>\mathrm{Ti}$ $>\mathrm{Y}>\mathrm{Yb}$ (Sun and McDonough, 1989). From a petrogenetic viewpoint, differences in abundance ratios between adjacent or nearly adjacent elements in this sequence are most likely to provide information about source compositions and degrees of melting. However, because of their mobility during late-stage alteration, abundances of $\mathrm{K}, \mathrm{Rb}$, and perhaps $\mathrm{Sr}$ in the Leg 121 lavas cannot be used to infer source characteristics or magmatic processes. The general picture that emerges from Figure 15 is that the Leg 121 basalts overlap with depleted MORB in the HREE region, but are relatively enriched in the more incompatible elements. This result is typical of oceanic island tholeiitic basalts. In detail, from $\mathrm{Nb}$ to $\mathrm{Yb}$ (except $\mathrm{Pb}$ ) Site 758 lavas have relative abundances that are similar to abundances of the primitive mantle. Only Ba, Th, and U are markedly depleted (Fig. 15). Lavas from Sites 756 and 757 are relatively more enriched in incompatible elements, and they peak in the Nb-Ta-LREE region of Figure 15. Lavas from flow Units 757C-F18 and 757C-F19 are broadly similar to lavas from Hole 756D, except that these Hole 757C lavas have very significant $\mathrm{P}$ and $\mathrm{Ti}$ depletions and relatively high Th and $U$ contents.

In addition, there are important intersite differences in REE abundances. Details of REE abundance variation are shown in Figures $9 \mathrm{E}$ and 12. Lavas from Hole $756 \mathrm{D}$ have chondrite-normalized REE patterns similar to those of tholeiitic basalts from oceanic islands and enriched MORBs (i.e., MORBs with (LREE/ HREE) $)_{N}>1$ ). Important features of these REE patterns are the shallow slopes from $\mathrm{La}$ to $\mathrm{Eu}$ and $(\mathrm{La} / \mathrm{Ce})_{\mathrm{N}}<1$. Compared with the Site 756 lavas, the lavas from flow Units 757C-F18 and 757C-F19 have a steeper slope in the La-Sm region, but a flatter slope from Eu to Lu. Lavas from Hole $758 \mathrm{~A}$ have the least fractionated REE patterns; $(\mathrm{La} / \mathrm{Ce})_{\mathrm{N}}$ is typically $<1$ and the ranges of $(\mathrm{La} / \mathrm{Sm})_{\mathrm{N}}$ and $(\mathrm{La} / \mathrm{Yb})_{\mathrm{N}}(0.90$ to 1.26 and 0.96 to 1.69 , respectively) are lower than those of basement lavas from Sites 756 and 757 (Figs. 9E and 12).

In contrast, there is considerable overlap in other abundance ratios involving elements of very similar incompatibility. For example, $\mathrm{Sr} / \mathrm{Nd}$ ratios are near chondritic except in plagioclase accumulative rocks from Hole $757 \mathrm{C}$ and flow Units $758 \mathrm{~A}-\mathrm{F} 1$ and 758A-F4 (Fig. 11). Abundance ratios of P/Nd in most of the lavas from the three Leg 121 sites overlap, typically ranging from 50 to 60 (Fig. 11). This range is slightly lower than the $74 \pm 13$ ratio for oceanic basalts cited by Sun and McDonough (1989), but it is similar to that for Hawaiian tholeiitic basalts. The major signal in the $\mathrm{P} / \mathrm{Nd}$ data is the anomalously low ratios in flow Units $757 \mathrm{C}$ F18 and 757C-F19. Similarly low ratios occur in other island and continental tholeiitic basalts (e.g., McDonough and Sun, 1985), but no explanation for $\mathrm{P} / \mathrm{Nd}$ fractionation is known when $\mathrm{P}$ abundance levels are well below the level needed for apatite saturation. The range in abundance ratios of $\mathrm{Hf} / \mathrm{Sm}$ (and $\mathrm{Zr} / \mathrm{Sm}$ ) in the Leg 121 lavas encompasses estimates for primitive mantle ratios (Fig. 11). The slightly lower $\mathrm{Ti} / \mathrm{Eu}$ of the upper lavas in Hole $757 \mathrm{C}$ probably reflects plagioclase accumulation. However, the anomalously high $\mathrm{Hf} / \mathrm{Sm}$ (and $\mathrm{Zr} / \mathrm{Sm}$ ) and low $\mathrm{Ti} / \mathrm{Eu}$ in flow Units $757 \mathrm{C}-\mathrm{F} 18$ and $757 \mathrm{C}-\mathrm{F} 19$ further define the distinctiveness of these lavas. Like other oceanic basalts the Leg 121 lavas have $\mathrm{Ce} / \mathrm{Pb}$ ratios greater than the chondritic ratio (Hofmann et al., 1986), but there is no systematic difference among the lavas from each site (Fig. 11).

In summary, the Leg 121 lavas define significant intersite compositional differences. Many of these differences, especially in the abundance ratios of incompatible elements (Figs. 11, 12, 14 , and 15), are plausibly related to differences in parental melt 


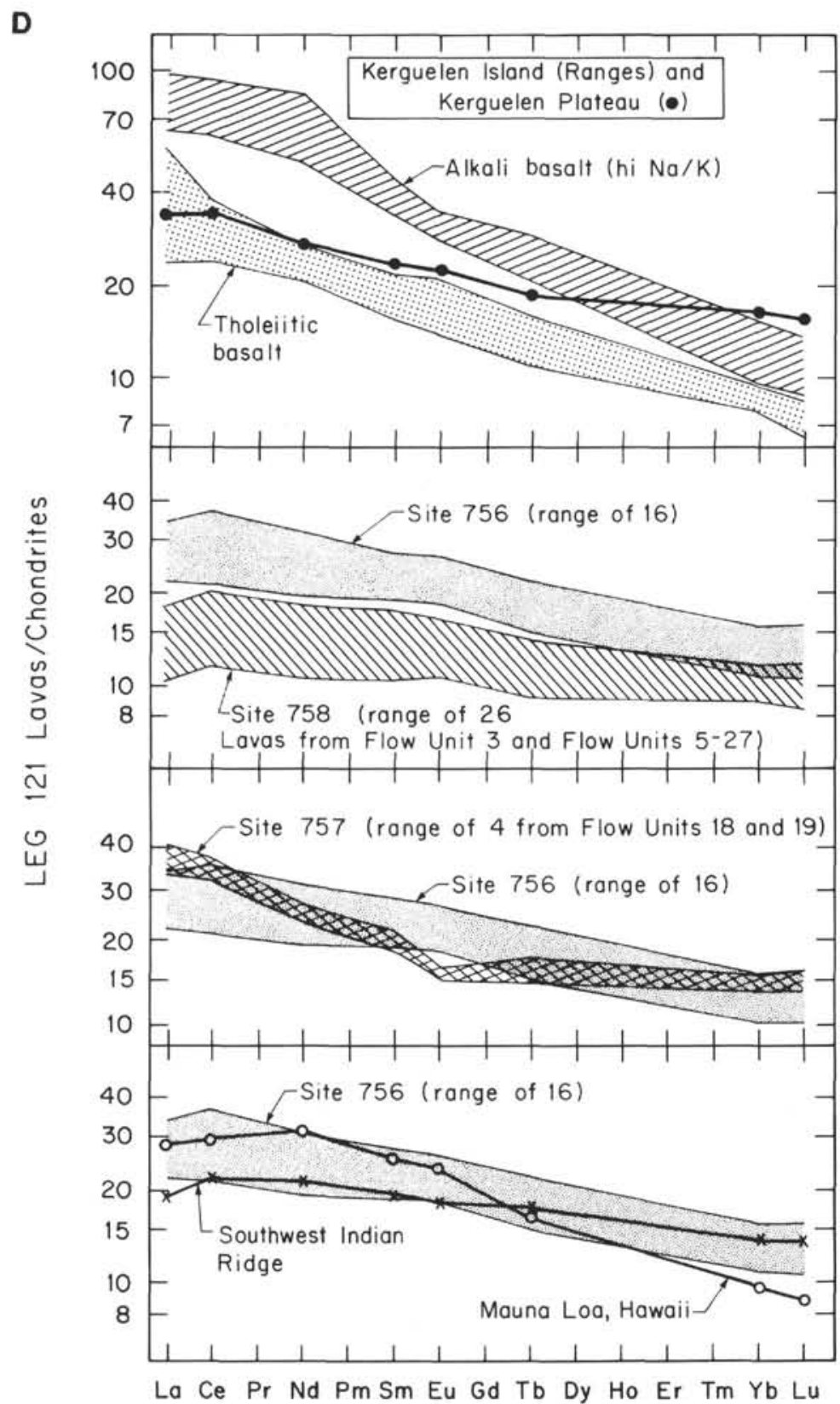

Figure 9 (continued).

compositions. Weis and Frey (this volume) showed that there are also important intersite differences in $\mathrm{Sr}, \mathrm{Nd}$, and $\mathrm{Pb}$ isotopic ratios. Thus, it is likely that the sources of parental magmas for each site were compositionally and isotopically distinct. In general, the compositions, but not the isotopic ratios, of the Leg 121 lavas are similar to those of oceanic island tholeiitic basalts (e.g., Hawaii). However, flow Units 757C-F18 and 757C-F19 have unusual characteristics (e.g., low $\mathrm{P} / \mathrm{Nd}$ and $\mathrm{Ti} / \mathrm{Eu}$ and high $\mathrm{Hf} / \mathrm{Sm}$ ) that require a process that significantly changed the abundance ratios of geochemically similar elements.

\section{Geochemical Comparisons of Basalts With DUPAL Isotopic Characteristics}

Weaver et al. (1986, fig. 2) noted that basalts with DUPAL isotopic characteristics from the South Atlantic (Tristan da Cunha and Gough islands and the Walvis Ridge) have distinctive incompatible element abundance signatures, notably atypically high
(>10) $\mathrm{Ba} / \mathrm{Nb}$ ratios. Some E-type MORBs dredged from the Southwest Indian Ridge (LeRoex et al., 1989, fig. 10) also have high $\mathrm{Ba} / \mathrm{Nb}$ ratios of $9-22$. Because these basalts from the South Atlantic Ocean and Southwest Indian Ocean have DUPAL isotopic characteristics (Hart, 1984), there has been a suggestion that basalts with DUPAL isotopic characteristics have distinctively high $\mathrm{Ba} / \mathrm{Nb}$ and $\mathrm{La} / \mathrm{Nb}$ (e.g., LeRoex et al., 1989, p. 483). This correlation between isotopic and trace element abundance ratios has provided constraints on the origin of the DUPAL anomaly. For example, small amounts of ancient pelagic sediment could account for unusually high $\mathrm{Ba} / \mathrm{Nb},{ }^{207} \mathrm{~Pb} / 204 \mathrm{~Pb}$, and ${ }^{208} \mathrm{~Pb} / 204 \mathrm{~Pb}$ in these DUPAL basalts (Weaver et al., 1986). However, the Leg 121 lavas that have DUPAL isotopic characteristics (Weis and Frey, this volume) have $\mathrm{Ba} / \mathrm{Nb}$ ratios lower than the primitive mantle estimate of 9.8 (Fig. 11). In addition, $\mathrm{Ba} / \mathrm{Nb}$ ratios are not uniformly high in lavas from the Kerguelen Archipelago. For example, Storey et al. (1988) reported $\mathrm{Ba} / \mathrm{Nb}$ ratios of $6.4,6.5$, 

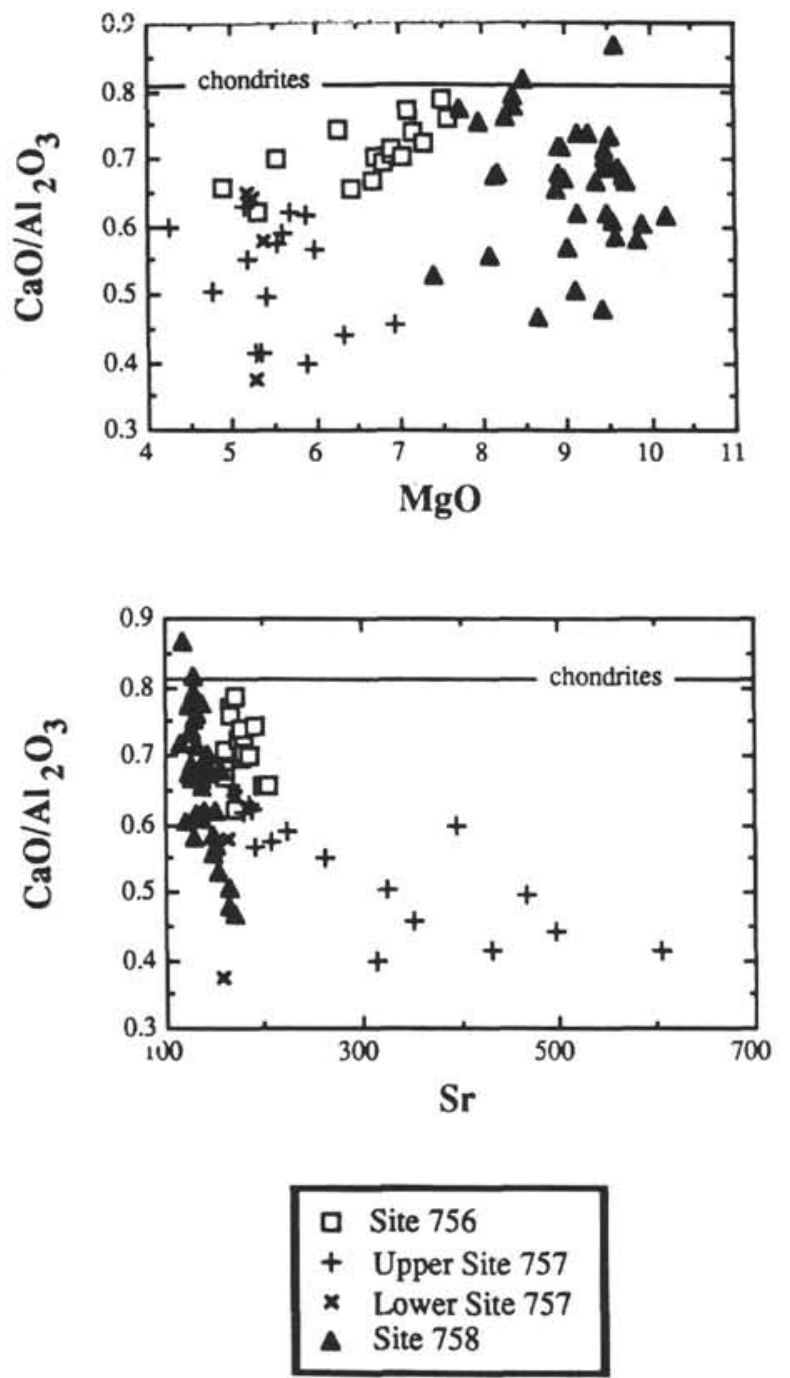

Figure 10. $\mathrm{CaO} / \mathrm{Al}_{2} \mathrm{O}_{3}$ vs. $\mathrm{MgO}$ (wt\%) and $\mathrm{Sr}$ content (ppm), with the chondritic $\mathrm{CaO} / \mathrm{Al}_{2} \mathrm{O}_{3}$ ratio indicated by a horizontal line. In the $\mathrm{MgO}$ plot only lavas from Site 756 define a systematic trend. The scatter in $\mathrm{CaO} / \mathrm{Al}_{2} \mathrm{O}_{3}$ at Sites 757 and 758 in part reflects postmagmatic alteration, but the dominant control at Site 757 is plagioclase accumulation, as shown by the $\mathrm{CaO} / \mathrm{Al}_{2} \mathrm{O}_{3}-\mathrm{Sr}$ trend.

9.8, and 15.6 for four tholeiitic basalts, the field given by Davies et al. (1989, fig. 7) for transitional and alkalic basalts from Kerguelen and Heard islands and tholeiitic basalts dredged from the Kerguelen Plateau ranges from 6 to 15 , and Gautier et al. (1990) reported a range of 5-12 for Kerguelen Archipelago basalts. Apparently, the association of high $\mathrm{Ba} / \mathrm{Nb}$ with DUPAL isotopic characteristics does not extend into the eastern Indian Ocean. Consequently, the trace element signature of the South Atlantic plume expressed at Tristan da Cunha and Gough islands and on the Walvis Ridge differs from the trace element signature of the mantle source (Kerguelen-Heard hot spot?) that created analogous volcanic features in the eastern Indian Ocean.

\section{Geochemical Evidence Bearing on the Origin of Ninetyeast Ridge}

The large volume of the Ninetyeast Ridge $\left(27.7 \times 10^{6} \mathrm{~km}^{3}\right.$, Schubert and Sandwell, 1989) and the $\mathrm{Sr}, \mathrm{Nd}$, and $\mathrm{Pb}$ isotopic characteristics of the lavas (Weis and Frey, this volume) are consistent with a large source of anomalous composition, such as a plume associated with a mantle hot spot. As summarized by the Shipboard Scientific Party (1989a), the present consensus is that Ninetyeast Ridge is a volcanic feature related to a mantle hot spot, probably the Kerguelen-Heard hot spot. In a recent discussion of the plate tectonic history of the eastern Indian Ocean, Royer and Sandwell (1989) concluded that the Kerguelen-Heard hot spot could be the unique source for volcanism on Ninetyeast Ridge and the Kerguelen Plateau.

A simple first-order question is: are the Ninetyeast Ridge lavas compositionally similar to lavas from the Kerguelen Archipelago? There are important geochemical similarities between lavas from Ninetyeast Ridge and the Kerguelen Archipelago. These include DUPAL isotopic characteristics (i.e., relatively high ${ }^{87} \mathrm{Sr} /{ }^{86} \mathrm{Sr},{ }^{207} \mathrm{~Pb} / 204 \mathrm{~Pb}$, and ${ }^{208} \mathrm{~Pb} / 204 \mathrm{~Pb}$ and low ${ }^{143} \mathrm{Nd} /{ }^{144} \mathrm{Nd}$, Weis and Frey, this volume) and the previously discussed absence of relatively high $\mathrm{Ba} / \mathrm{Nb}$ ratios in these basalts with DUPAL isotopic characteristics. These similarities are consistent with the hypothesis that components from a Kerguelen-Heard mantle plume have contributed to forming Ninetyeast Ridge. Moreover, Dosso et al. (1988) and Storey et al. (1989) proposed that the Kerguelen-Heard plume has had a widespread influence in the eastern Indian Ocean. Specifically, Dosso et al. (1988) showed that dredged basalts from near the St. Paul Fracture Zone, slightly off the axis of the Southeast Indian Ridge, have isotopic ratios similar to lavas from the Kerguelen Archipelago. In this regard, we note that in the eastern Indian Ocean submarine basalts with incompatible element abundance characteristics of oceanic island basalts are not confined to Ninetyeast Ridge, Kerguelen Plateau, and the St. Paul-Amsterdam platform; basalts with (LREE/ HREE) $>1$ also occur at DSDP Sites 211, 215, and 256 (see Fig. 1 and Frey et al., 1977).

However, there are also important compositional differences between the Ninetyeast Ridge lavas and Kerguelen Archipelago lavas. For example, basaltic lavas from Kerguelen Island have higher LREE contents and higher LREE/HREE ratios (Figs. 9E and 12). Specifically, Storey et al. (1988) reported that $(\mathrm{La} / \mathrm{Yb})_{\mathrm{N}}$ ranges from 3.6 to 10.5 in seven tholeiitic and high- $\mathrm{Na} / \mathrm{K}$ alkalic basalts from the Loranchet Peninsula of Kerguelen Island, and Gautier et al. (1990) reported a $(\mathrm{La} / \mathrm{Yb})_{\mathrm{N}}$ range of 5.0 to 10.3 in six transitional basalts from this peninsula and the Central Plateau. In contrast, the highest $(\mathrm{La} / \mathrm{Yb})_{\mathrm{N}}$ ratio in the Leg 121 basalts is 2.8 in the lower flow units of Hole $757 \mathrm{C}$, and all lavas from Site 758 have $(\mathrm{La} / \mathrm{Yb})_{\mathrm{N}}<1.7$. There are equally significant differences in $\mathrm{La} / \mathrm{Ce}$ and $\mathrm{Sm} / \mathrm{Nd}$ ratios that are not readily changed by postmelting processes. There is also qualitative consistency between $\mathrm{Sm} / \mathrm{Nd}$ and ${ }^{143} \mathrm{Nd} /{ }^{144} \mathrm{Nd}$ ratios; that is, the Hole $758 \mathrm{~A}$ lavas have near-chondritic $\mathrm{Sm} / \mathrm{Nd}$ ratios $\left((\mathrm{Sm} / \mathrm{Nd})_{\mathrm{N}}\right.$ from $\sim 0.8$ to 1.3$)$ and ${ }^{143} \mathrm{Nd} /{ }^{144} \mathrm{Nd}$ ratios that are slightly higher than the estimated bulk-earth ratio, whereas lavas from the Kerguelen Archipelago have $(\mathrm{Sm} / \mathrm{Nd})_{\mathrm{N}}<1$ and an ${ }^{143} \mathrm{Nd} /{ }^{144} \mathrm{Nd}$ range to less than the bulk-earth ratio (see fig. 4 of Weis and Frey, this volume).

In addition, the relative depletion in the Leg 121 lavas of the most incompatible elements, Th and $\mathrm{La}$, is demonstrated by the less than chondritic ratios of $\mathrm{Th} / \mathrm{La}, \mathrm{Th} / \mathrm{Ta}, \mathrm{Ba} / \mathrm{La}$, and $\mathrm{Ba} / \mathrm{Nb}$ (Fig. 11). Specifically, Th/La ratios range from near values of primitive mantle $(\sim 0.12)$ in the uppermost flow units of Holes $756 \mathrm{C}$ and 756D and the lower flow units (757C-F18 and 757CF19) of Hole 757C to significantly lower values, $0.12-0.04$, in some lavas from Holes 757C and 758A (Fig. 11). These low Th/La ratios are in samples that have low, $0.1-0.5 \mathrm{ppm}$, Th contents. This scatter to low $\mathrm{Th} / \mathrm{La}$ may in part reflect the poor precision and inaccuracies in our Th data at $<0.5 \mathrm{ppm}$. In addition, most lavas from Holes $756 \mathrm{D}, 757 \mathrm{C}$, and $758 \mathrm{~A}$ span a range in $\mathrm{Th} / \mathrm{Ta}$ that is below the primitive mantle $\mathrm{Th} / \mathrm{Ta}$ ratio, 2.07 , estimated by Sun and McDonough (1989), but lavas from flow Units 757C-F18 

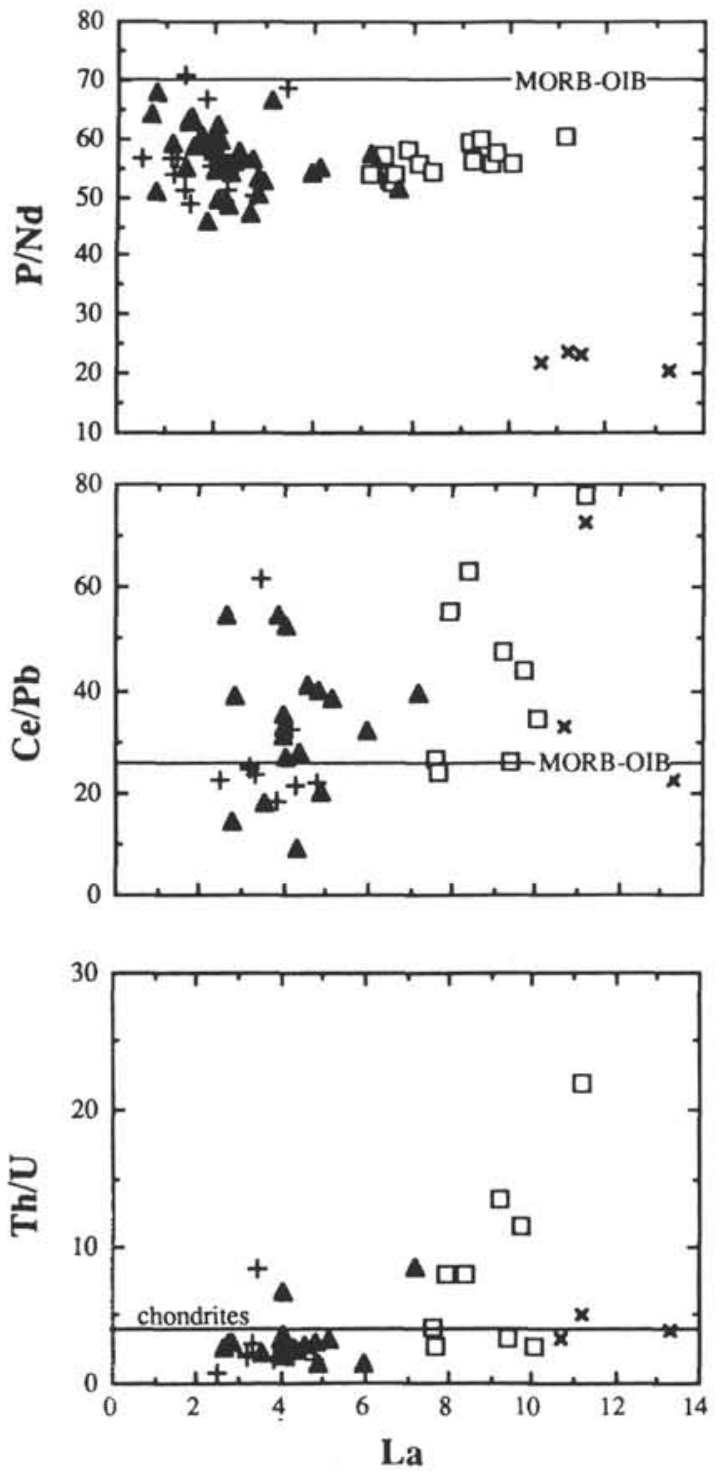
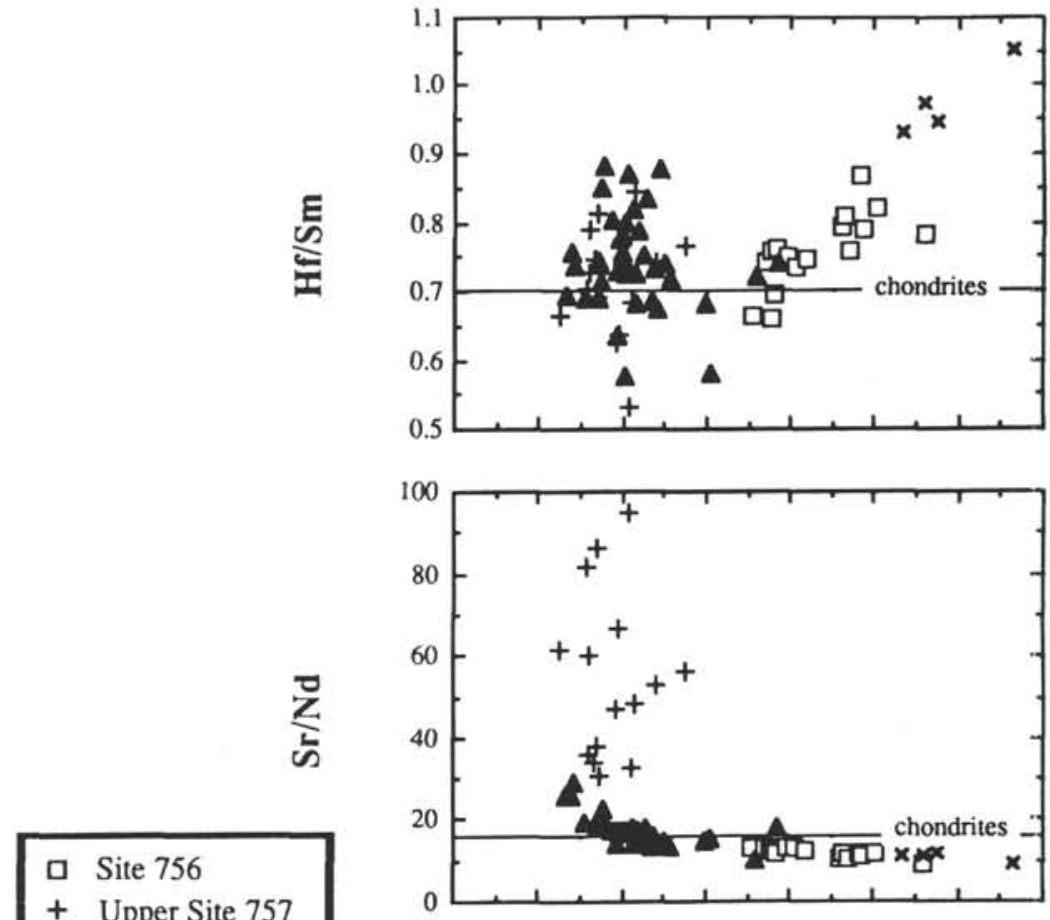

$\times \quad$ Lower Site 757

A Site 758

Figure 11. Abundance ratios involving incompatible elements vs. La content (ppm). Chondritic and typical MORB-OIB ratios are indicated by the horizontal lines (Sun and McDonough, 1989). In most of the Leg 121 samples ratios of $\mathrm{Ba} / \mathrm{Nb}, \mathrm{Ba} / \mathrm{La}, \mathrm{Th} / \mathrm{Ta}$, and $\mathrm{Th} / \mathrm{La}$ are less than the chondritic ratios. Lavas from flow Units 757C-F18 and 757C-F19 have unusually and distinctively low P/Nd and Ti/Eu; in addition, they have relatively high Hf/Sm, Ba/Nb, and Th/Ta. Like most OIB and MORB lavas, $\mathrm{Ce} / \mathrm{Pb}$ ratios in most of the Leg 121 lavas are greater than the chondritic ratio. $\mathrm{Sr} / \mathrm{Nd}$ ratios are anomalously high in Hole $757 \mathrm{C}$ lavas that contain accumulative plagioclase, and $\mathrm{Th} / \mathrm{U}$ ratios are very high in some of the uppermost flows from Hole $756 \mathrm{D}(\mathrm{U}$ and $\mathrm{Pb}$ data from Weis and Frey, this volume).

and 757C-F19 have distinctly higher Th/Ta (Fig. 11). Qualitatively, several geochemical characteristics of the Leg 121 lavas are consistent with a major role for a depleted component (i.e., a MORB source) in the sources of the Leg 121 lavas. Specific geochemical features that require a depleted source component are the small amount of relative LREE enrichment in the lavas from Hole 758A (Fig. 9C), the ubiquity of $(\mathrm{La} / \mathrm{Ce})_{\mathrm{N}}<1$ in lavas from Sites 756 and 758 (Fig. 12), and the relative depletion in the highly incompatible elements $\mathrm{Ba}$ and $\mathrm{Th}$, but the near-chondritic relative abundances of the elements $\mathrm{Nb}$ through $\mathrm{Yb}$ (Fig. 15).

It is a paradox that the lavas from Site 758 have $\mathrm{Pb}$ isotopic ratios similar to those of the Kerguelen lavas, but among the Leg 121 lavas their $\mathrm{La} / \mathrm{Ce}, \mathrm{La} / \mathrm{Sm}$, and LREE/HREE ratios are the most dissimilar to those of the Kerguelen lavas (Fig. 9D; Weis and Frey, this volume, fig. 7). Apparently the component or process that controlled $\mathrm{Pb}$ isotopic ratios was equally important in forming the basalts at Site 758 and in the Kerguelen Archipelago, but the component or process that created relative LREE enrichment and low ${ }^{143} \mathrm{Nd} /{ }^{144} \mathrm{Nd}$ was much more important in creating the Kerguelen Archipelago lavas. The occurrence of DUPAL-like $\mathrm{Pb}$ isotopic ratios in the Site 758 tholeiitic basalts that have a depleted incompatible element abundance signature (i.e., less than the chondritic ratios of $\mathrm{Th} / \mathrm{La}, \mathrm{Th} / \mathrm{Ta}, \mathrm{Ba} / \mathrm{La}$, $\mathrm{Ba} / \mathrm{Nb}$, and $\mathrm{La} / \mathrm{Ce}$, Figs. 11,12 , and 15 ) is consistent with the proposal (e.g., Gautier et al., 1990) that the Pb isotopic characteristics are controlled by small amounts of a $\mathrm{Pb}$-rich component (e.g., old recycled sediments).

What is the explanation for the geochemical differences between lavas from Ninetyeast Ridge and the Kerguelen Archipelago? Gautier et al. (1990) proposed two hypotheses for the temporal trend from tholeiitic to alkaline volcanism in the Kerguelen Archipelago: (1) derivation of magmas from increasing 

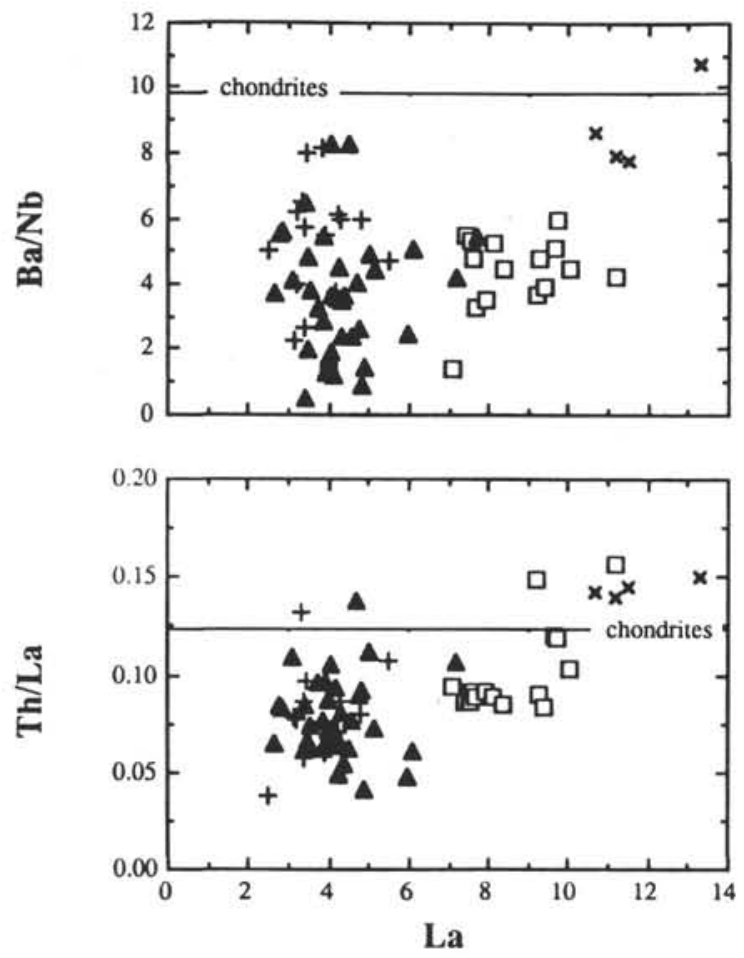

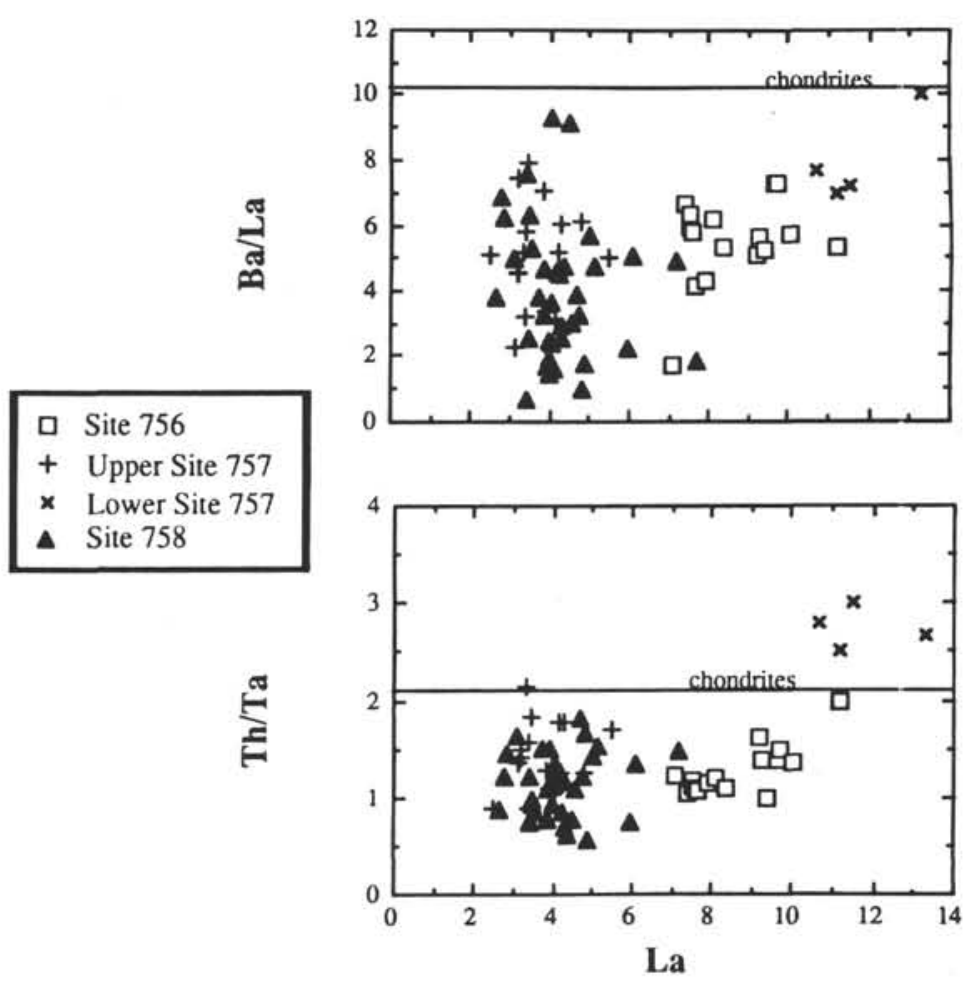

Figure 11 (continued).

depth, in which older tholeiitic magmas were derived from shallower depths than younger alkaline lavas, and (2) systematic temporal changes in mixing proportions of MORB- and plumerelated components as the Southeast Indian Ridge migrated away from a hot-spot source (e.g., Storey et al., 1988). Both of these hypotheses may also be applicable in accounting for geochemical differences between lavas from Ninetyeast Ridge and the Kerguelen Archipelago. For example, the low total iron and high $\mathrm{Al}_{2} \mathrm{O}_{3}$ contents and $\mathrm{Al}_{2} \mathrm{O}_{3} / \mathrm{CaO}$ ratios inferred for the parental melts of lavas from Hole $757 \mathrm{C}$ are consistent with segregation of melt at low pressures $(10 \mathrm{~kb})$. In addition, the relatively high Sc contents (Fig. 6) and the absence of fractionation among HREE (i.e., nearly horizontal slopes on chondrite-normalized plots, Fig. 9E) indicate that the Leg 121 lavas did not form in equilibrium with garnet. In contrast, much like the Hawaiian lavas, the HREE are fractionated in lavas from the Kerguelen Archipelago. Moreover, in Kerguelen lavas, abundances of HREE are much more constant than LREE abundances (Fig. 9E). Also, the abundance of $\mathrm{Sc}$, an element preferentially concentrated in garnet, is much lower in the Kerguelen lavas than in the Leg 121 lavas (Fig. 6). Therefore, lavas erupted in the Kerguelen Archipelago may have equilibrated with garnet.

The second alternative proposed by Gautier et al. (1990) is also relevant. $\mathrm{Sr}$ and $\mathrm{Nd}$ isotopic data for Kerguelen Archipelago lavas have been used extensively to argue for mixing between plumerelated and MORB-related components (e.g., Gautier et al., 1990; Storey et al., 1988, 1989; Weis et al., 1987, 1989a, 1989b). Plate tectonic reconstructions of the eastern Indian Ocean require that much of Ninetyeast Ridge formed at or near a spreading-ridge axis (e.g., Shipboard Scientific Party, 1989a; Royer et al., this volume). Therefore, the lavas forming Ninetyeast Ridge may have been largely derived from two physically and compositionally distinct mantle sources-asthenosphere and a hot spot-related plume. Because lavas from Ninetyeast Ridge have $\mathrm{Sr}$ and $\mathrm{Nd}$ isotopic ratios intermediate between those of typical MORB and alkalic lavas from Kerguelen Island, they may represent mixtures between asthenosphere and plume-related components; however, in detail, the $\mathrm{Sr}, \mathrm{Nd}$, and $\mathrm{Pb}$ isotopic characteristics of the Leg 121 lavas require that the plume component was isotopically heterogeneous, perhaps consisting of two plume components, one related to Kerguelen-Heard and the other related to Amsterdam-St. Paul (Weis and Frey, this volume).

Based on shipboard data for the Leg 121 lavas, these lavas have $\mathrm{Y} / \mathrm{Nb}$ and $\mathrm{Zr} / \mathrm{Nb}$ ratios 6 between the extremes defined by MORB and lavas from Kerguelen Island; moreover, the linear trend defined by these three groups of lavas supports an interpretation of mixing between a MORB-related asthenosphere source and an oceanic island basalt mantle component represented by lavas from Kerguelen Island (see Shipboard Scientific Party, 1989a, fig. 13). Our $\mathrm{Y}, \mathrm{Zr}$, and $\mathrm{Nb}$ data are consistent with this hypothesis, except that some complexity is required by lavas from flow Units 757C$\mathrm{F} 18$ and $757 \mathrm{C}-\mathrm{F} 19$, which are offset to high $\mathrm{Zr} / \mathrm{Nb}$ at a given $\mathrm{Y} / \mathrm{Nb}$ (Fig. 14). A difficulty with this plot is that $\mathrm{Y}$ and $\mathrm{Nb}$ do not usually have a similar degree of incompatibility (e.g., see element order in Fig. 15). A ratio plot such as $\mathrm{Th} / \mathrm{Ta}-\mathrm{La} / \mathrm{Ta}$, involving elements with very similar degrees of incompatibility, shows no lineation (Fig. 14). Some of the scatter results from the analytical uncertainty in Th and Ta data, but another important factor is that MORB and Kerguelen Island lavas do not have substantially different $\mathrm{Th} / \mathrm{Ta}$ and $\mathrm{La} / \mathrm{Ta}$ (Fig. 14). In this regard, a somewhat

\footnotetext{
${ }^{6}$ The rationale for choosing the ratios plotted in Figure 14 includes (1) a common denominator in the ratio leads to a straight line for two component mixing, (2) plausible mixing components should have significantly different ratios, (3) the intersite variation in abundance ratios must exceed the variation resulting from analytical uncertainty and postmagmatic alteration, and (d) in order to infer source characteristics each abundance ratio should involve geochemically similar elements, and the elements used should not be highly sensitive to crustal fractionation processes (e.g., $\mathrm{Sr}$ is controlled by feldspar segregation).
} 

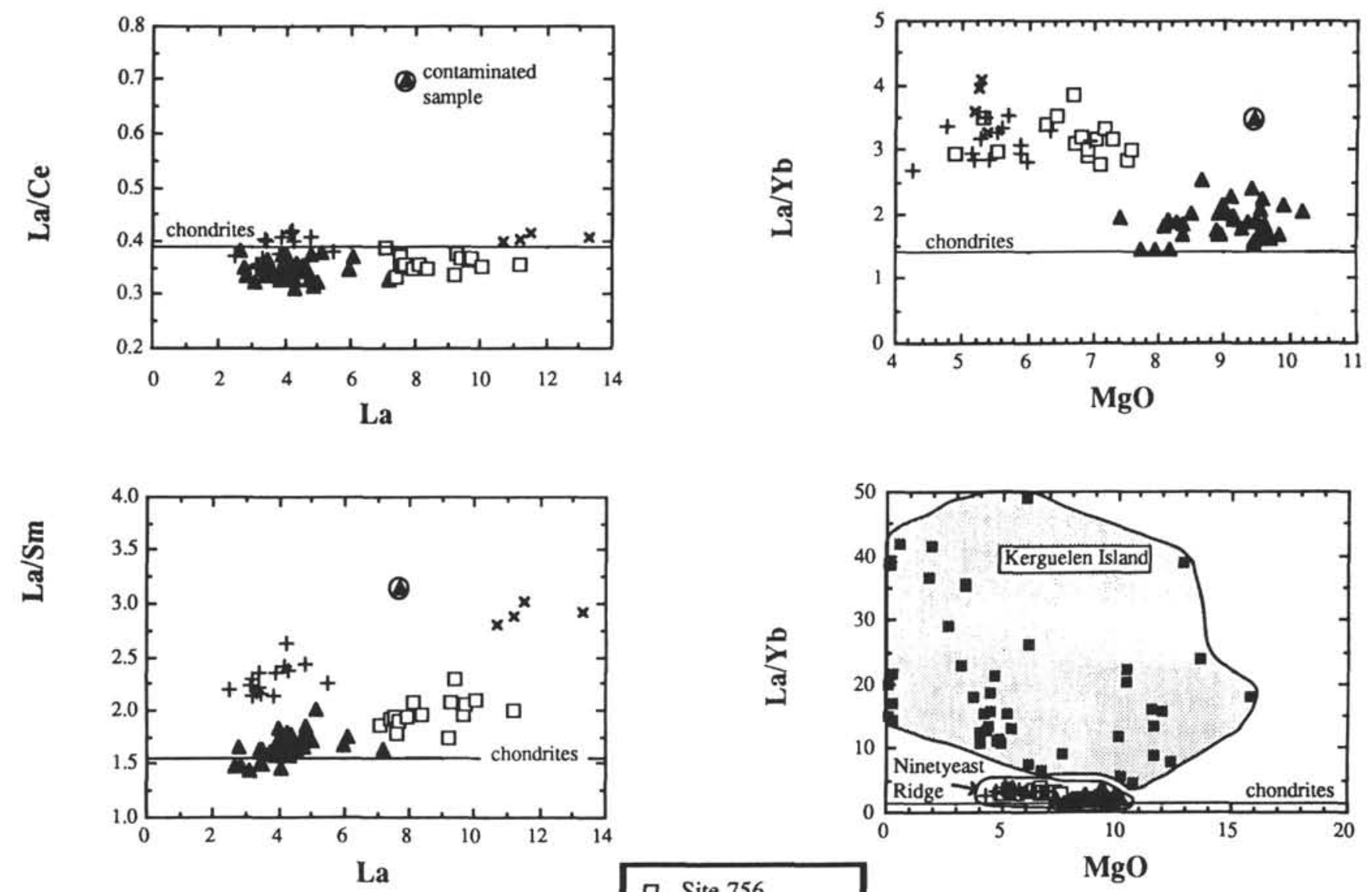

\begin{tabular}{|ll|}
\hline$\square$ & Site 756 \\
+ & Upper Site 757 \\
$\times$ & Lower Site 757 \\
$\mathbf{\Delta}$ & Site 758 \\
\hline
\end{tabular}

Figure 12. $\mathrm{La} / \mathrm{Sm}, \mathrm{La} / \mathrm{Ce}$, and $\mathrm{La} / \mathrm{Yb}$ ratios vs. La content (ppm) or $\mathrm{MgO}$ content (wt\%). Chondritic ratios are indicated by horizontal lines. La-contaminated Sample 121-758A-66R-4, 6-12 cm, is circled (see text). Lavas from Site 758 have the lowest $\mathrm{La} / \mathrm{Sm}$ and La/Yb ratios, and, as in other plots, data from each site form distinctive groups. Lavas from flow Units 757C-F18 and 757C-F19 have high $\mathrm{La}$ and $\mathrm{La} / \mathrm{Sm}$ ratios. Note in the $\mathrm{La} / \mathrm{Yb}-\mathrm{MgO}$ plot that at a given $\mathrm{MgO}$ content lavas from Kerguelen Island (solid squares) have significantly higher $\mathrm{La} / \mathrm{Yb}$ than lavas from Ninetyeast Ridge.

better plot involves $\mathrm{Hf} / \mathrm{La}-\mathrm{Sm} / \mathrm{La}$. These ratios are significantly different at the three sites (Fig. 14), and they should not be extremely sensitive to postmelting magmatic and alteration processes. As in the $\mathrm{Y} / \mathrm{Nb}-\mathrm{Zr} / \mathrm{Nb}$ plot, the three Leg 121 sites define a linear $\mathrm{Hf} / \mathrm{La}-\mathrm{Sm} / \mathrm{La}$ trend (Fig. 14) that is broadly consistent with mixing of components related to MORB (high $\mathrm{Sm} / \mathrm{La}$ and $\mathrm{Zr} / \mathrm{La}$ ) and Kerguelen Island lavas (low $\mathrm{Sm} / \mathrm{La}$ and $\mathrm{Zr} / \mathrm{La}$ ). In each case, lavas from Site 758 are closest to MORB. However, in the $\mathrm{Y} / \mathrm{Nb}-\mathrm{Zr} / \mathrm{Nb}$ and $\mathrm{Hf} / \mathrm{La}-\mathrm{Sm} / \mathrm{La}$ plots in Figure 14 the relative positions of many lavas from Sites 756 and 757 are reversed. This result is inconsistent with two-component mixing. Either the mixing process was more complex or these trace element ratios were modified subsequent to the mixing event.

Another complication that may be expressed in the composition of the Ninetyeast Ridge lavas is that the location of volcanism on Ninetyeast Ridge relative to the hot spot and spreading-ridge axes probably varied with time. Royer and Sandwell (1989) and Royer et al. (this volume) proposed a complex temporal relationship between the location of the hot spot and spreading-ridge axis. If the distance between the hot spot and a spreading-ridge axis was variable, a likely result is varying mixing proportions between the plume and asthenosphere components. These changes in mixing proportions should be reflected in basalt compositions (e.g., Schilling et al., 1985).

Therefore, an important question is: do the compositions of the Ninetyeast Ridge lavas reflect temporal changes in mantle source components or their mixing proportions? In individual Hawaiian volcanoes temporal changes in mixing proportions occur on the scale of $\leq 10^{5}$ yr (e.g., Chen and Frey, 1985; Kurz and Kammer, 1991). Also, radiogenic isotopic ratios in Kerguelen Island lavas have varied systematically on a scale of several million years, and these trends have been interpreted as resulting from the variable mixing of components derived from a mantle plume, asthenosphere, and lithosphere (Gautier et al., 1990; Storey et al., 1988, 1989; Weis et al., 1989a, 1989b). Although comprehensive geochemical data for only three sites along nearly $5000 \mathrm{~km}$ of Ninetyeast Ridge are clearly insufficient to answer this question, there is no evidence for a simple trend. For example, the oldest lavas, from Site 758 , on Ninetyeast Ridge are isotopically similar to Kerguelen Island lavas that are much younger, but these two groups have very different $\mathrm{Sm} / \mathrm{Nd}$ and LREE/HREE ratios. Lavas from Site 756, which are comparable in age to the oldest Kerguelen Island lavas, have higher ${ }^{206} \mathrm{~Pb} / 204 \mathrm{~Pb}$ than the Kerguelen lavas. In addition, at Hawaiian volcanoes much of the evidence 


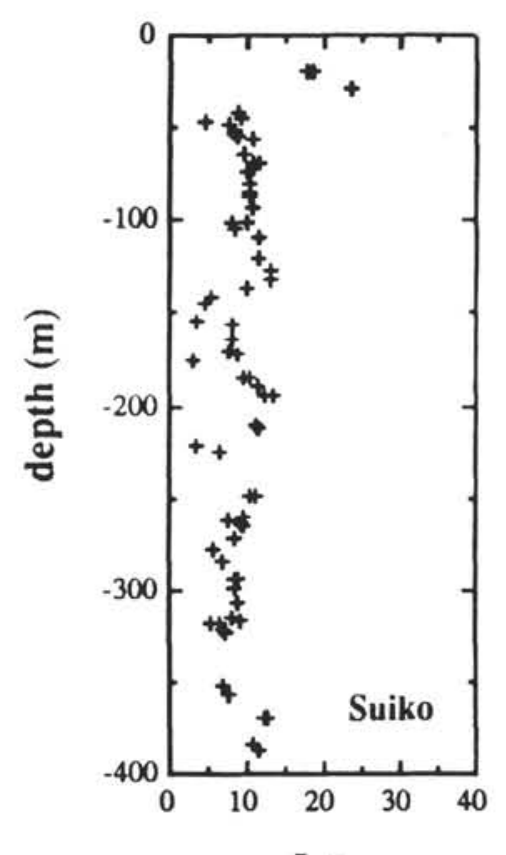

La
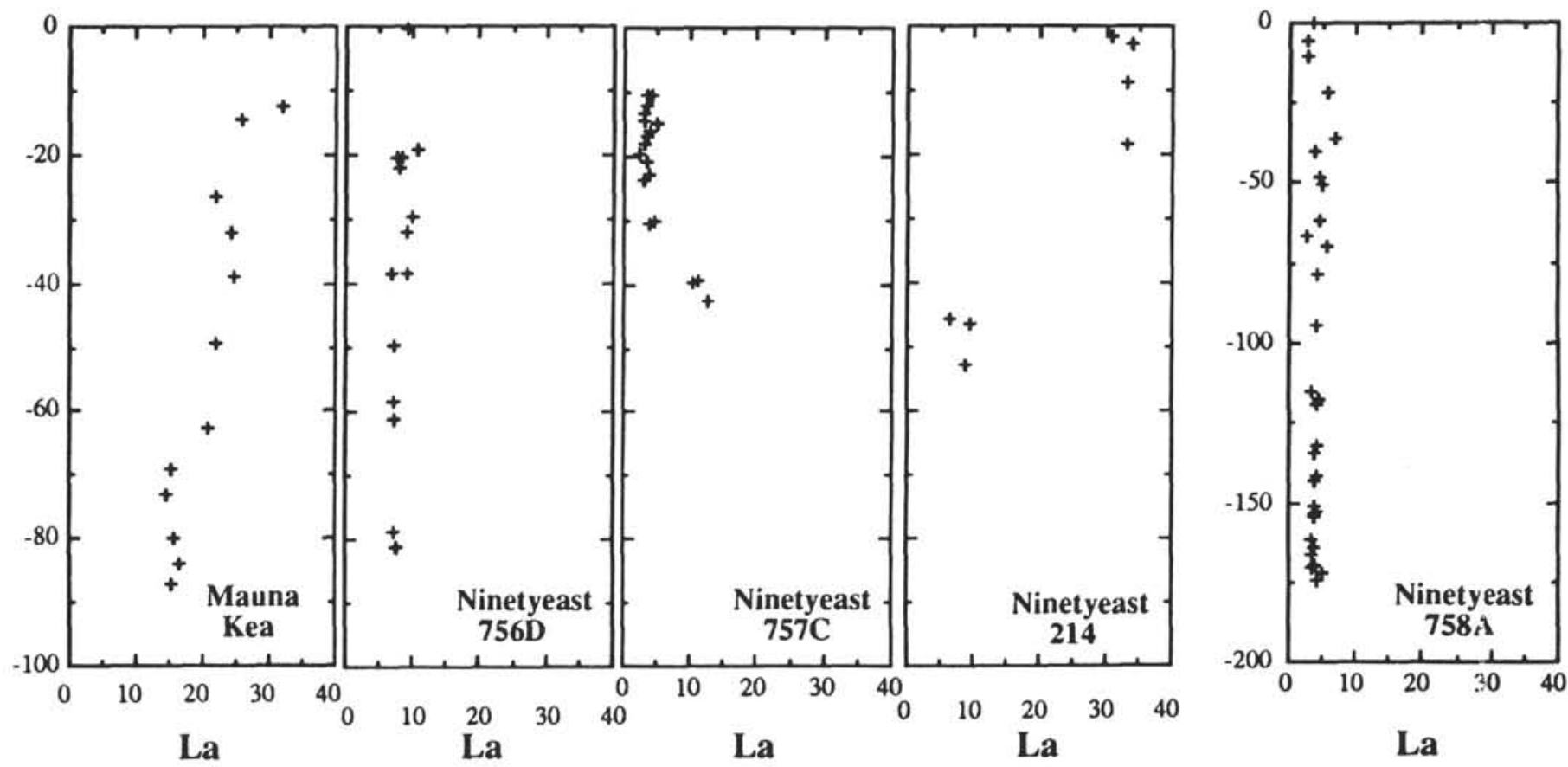

Figure 13. Abundances (ppm) of the incompatible element La vs. depth below the sediment contact for basaltic drill cores from Suiko seamount in the Central Emperor Seamounts and for DSDP Site 214 and ODP Holes 756D, 757C, and 758A on Ninetyeast Ridge. Also shown is a subaerial stratigraphic section from near the top of Mauna Kea Volcano. Note that in both of the stratigraphic sequences related to the Hawaiian hot spot the uppermost lavas have a higher La content. At Suiko Seamount this reflects $8.5 \mathrm{~m}$ of alkalic basalt that overlies $379 \mathrm{~m}$ of tholeiitic basalt (data from Bence et al., 1980; Cambon et al., 1980; Clague and Frey, 1980). At Mauna Kea volcano the increase in La results from hawaiites that overlie alkalic basalts that overlie tholeiitic basalts (Waikahalulu Gulch, Frey et al., 1990). On Ninetyeast Ridge a similar upsection increase in La was found at Site 214, where oceanic andesitic lavas overlie basaltic lavas (Thompson et al., 1974). However, similar increases in La content (and other incompatible elements) were not found in cores from Leg 121 Holes 756D, 757C, and 758A. 

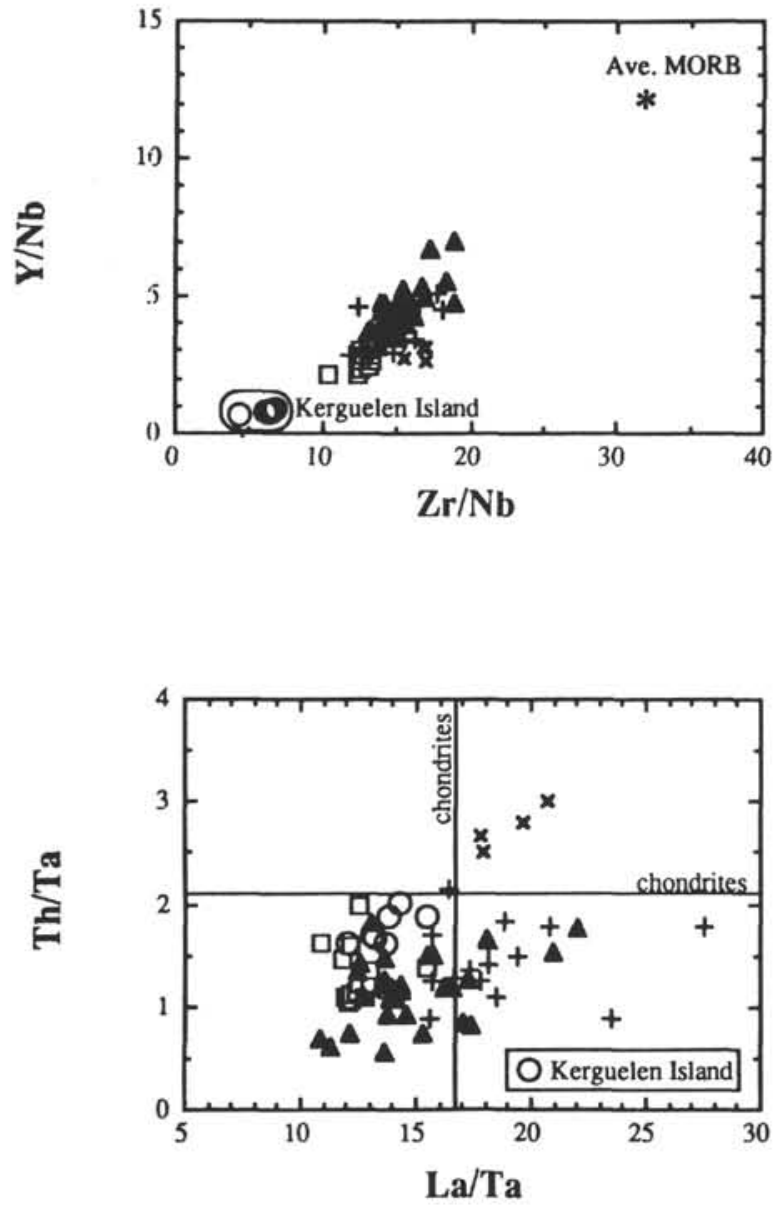

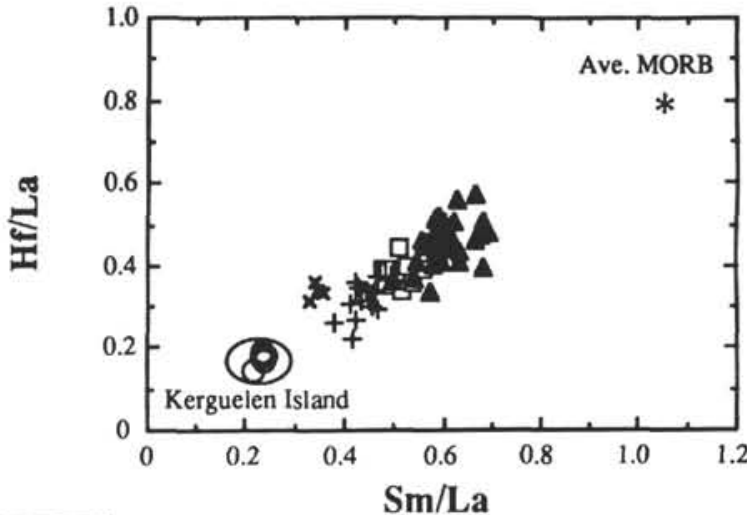

$$
\begin{array}{ll}
\hline & \text { Site } 756 \\
+ & \text { Upper Site } 757 \\
\times \quad & \text { Lower Site } 757 \\
\Delta & \text { Site } 758
\end{array}
$$

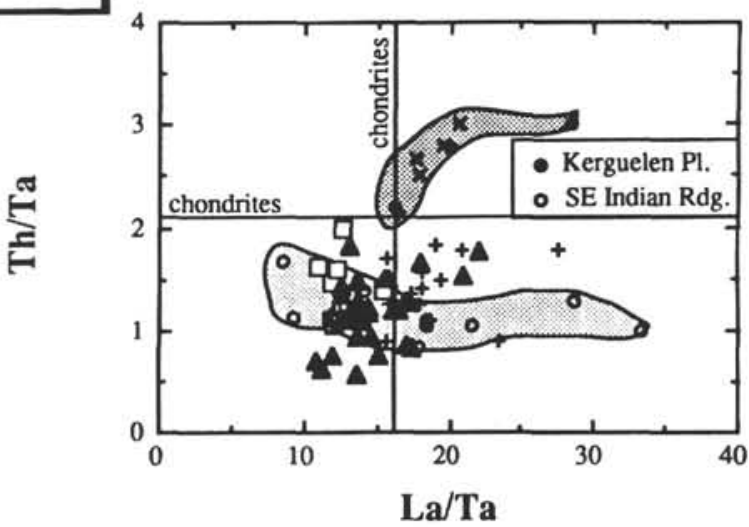

Figure 14. $\mathrm{Y} / \mathrm{Nb}-\mathrm{Zr} / \mathrm{Nb}, \mathrm{Hf} / \mathrm{La}-\mathrm{Sm} / \mathrm{La}$, and $\mathrm{Th} / \mathrm{Ta}-\mathrm{La} / \mathrm{Ta}$ plots. These incompatible element abundance ratios may reflect source characteristics (see footnote 6 in text). Two-component mixing is represented by a straight line. In the $\mathrm{Hf} / \mathrm{La}-\mathrm{Sm} / \mathrm{La}$ and $\mathrm{Y} / \mathrm{Nb}-\mathrm{Zr} / \mathrm{Nb}$ plots, the Leg 121 lavas have ratios intermediate to MORB and lavas from Kerguelen Island. In both cases lavas from Hole 758A are closest to average MORB (Sun and McDonough, 1989), but the relative positions of many lavas from Holes $756 \mathrm{D}$ and $757 \mathrm{C}$ are reversed in the two plots. A notable feature of the $\mathrm{Th} / \mathrm{Ta}-\mathrm{La} / \mathrm{Ta}$ plots is the overlap of the fields defined by lavas from Leg 121, Kerguelen Island, and the Southeast Indian Ridge (lower shaded area). Although La/Ta ratios in the Site 756 lavas are lower than in the Site 757 lavas, the La/Ta range of the Lè 121 lavas is centered around the chondritic ratio. In contrast, Th/Ta ratios in the Leg 121 samples are generally less than the chondritic ratio; however, like lavas from the Kerguelen Plateau, lavas from flow Units 757C-F18 and 757C-F19 are offset to higher Th/Ta (upper shaded area). Data for samples from Kerguelen Island, Kerguelen Plateau, and the Southeast Indian Ridge are from Gautier et al. (1990), D. Weis and F. A. Frey (unpubl. data), Storey et al. (1988), Davies et al. (1989), and Dosso et al. (1988).

for changes in proportions of source components is manifested as individual volcanoes move away from the hot spot (e.g., Chen and Frey, 1985). A similar trend is not evident at individual sites on Ninetyeast Ridge.

Is there evidence for a sub-Gondwana lithosphere component in the Leg 121 lavas? Abundance ratios involving the highly incompatible elements $\mathrm{Th}, \mathrm{Ta}$, and $\mathrm{La}$ have been used by Loubet et al. (1988) to classify oceanic island basalts (OIBs). They found that OIBs with relatively radiogenic $\mathrm{Sr}$ and $\mathrm{Pb}$ isotopic ratios have distinctively high $\mathrm{Th} / \mathrm{Ta}, \mathrm{La} / \mathrm{Ta}$, and $\mathrm{Th} / \mathrm{La}$ ratios. In particular, they suggested that high $\mathrm{Th} / \mathrm{Ta}$ ratios (> chondritic) reflect the presence of recycled continental crust in the sources of OIB. In addition, Storey et al. (1989) argued that $\mathrm{Th} / \mathrm{Ta}$ ratios in basalts from the eastern Indian Ocean increase in the following sequence: Southeast Indian Ridge axial basalts < Ninetyeast Ridge basalts $<$ Kerguelen Plateau (dredged samples) < continental basalts, as represented by 120 -Ma lamprophyres in India. They suggested that continental lithosphere was a significant source component during formation of the Kerguelen Plateau and perhaps the early formation of Ninetyeast Ridge. We find that most Leg 121 lavas have $\mathrm{Th} / \mathrm{Ta}$ ranging from $\sim 0.5$ to 2 with the $\mathrm{Th} / \mathrm{Ta}$ ratios of most lavas from Sites 756 and 757 between the primitive mantle estimates of 1.40 (Loubet al., 1988) and 2.07 (Sun and McDonough, 1989). As shown in Figure 14 (Loubet et al., 1988; Storey et al., 1989), basalts from Kerguelen and Heard islands also have Th/Ta ratios in this range. Thus, unlike many OIBs in the Southwest Pacific, lavas related to the Kerguelen hot spot do not have incompatible element ratios reflecting a continental signature. Lavas from flow Units 757C-F18 and 757C-F19 are an exception. Compared with the other Leg 121 basalts, they have distinctly higher Th/Ta and Th/La (2.5-3 and 0.14-0.15), but their La/Ta ratios are similar (Figs. 12 and 14). Although the higher Th/Ta and $\mathrm{Th} / \mathrm{La}$ in the lowermost flows of Hole $757 \mathrm{C}$ may reflect a continental-related component, isotopic ratios in these lavas are within the range defined by the other Leg 121 lavas. Also, relative to other basalts from Hole 757C, lavas from flow Units 757C-F18 


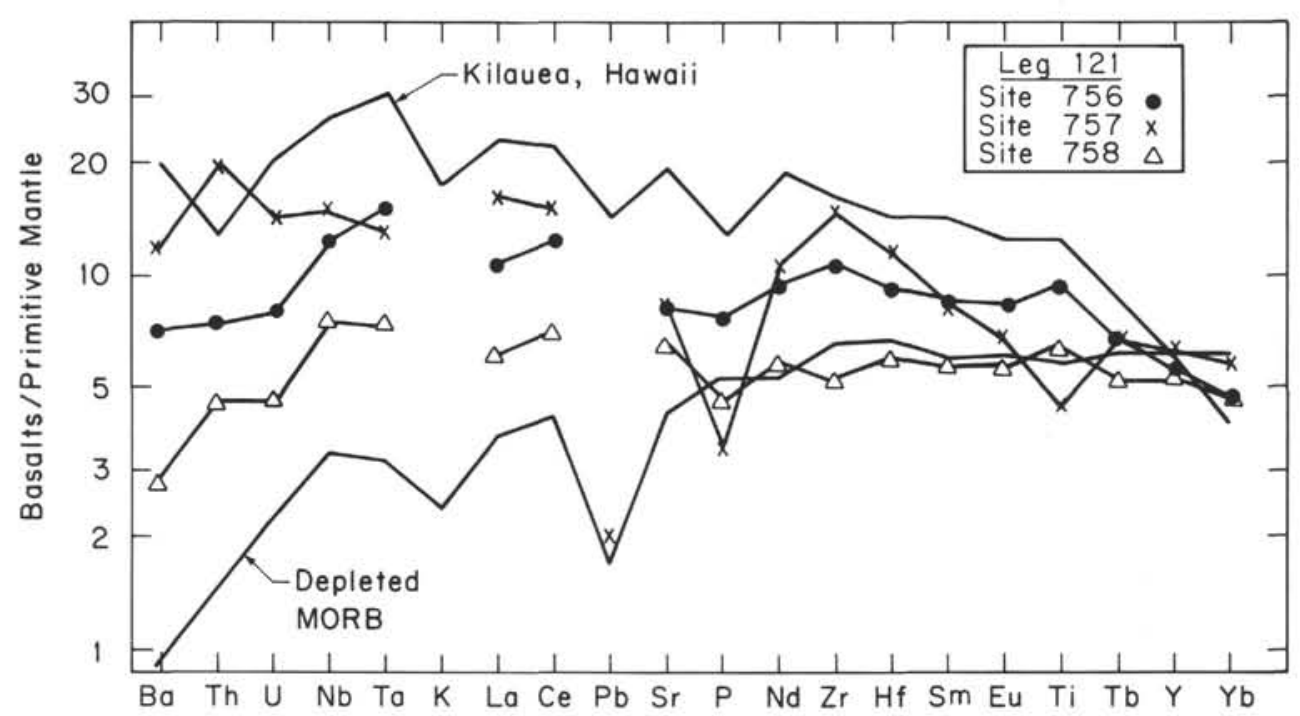

Figure 15. Incompatible elements in Leg 121 lavas normalized to the primitive mantle abundances of Sun and McDonough (1989). The Leg 121 lavas plotted are believed to be representative of melt compositions: Samples $121-756 \mathrm{D}-12 \mathrm{R}-2,28-33 \mathrm{~cm}(7.28 \% \mathrm{MgO}), 121-757 \mathrm{C}-12 \mathrm{R}-1,104-110 \mathrm{~cm}(5.26 \% \mathrm{MgO})$, and 121-758A-69R-1, $37-43 \mathrm{~cm}(8.38 \% \mathrm{MgO})$. Abundances of $\mathrm{K}$ in the Leg 121 lavas are not plotted because they were affected by postmagmatic processes. Shown for comparison are data for a Kilauea basalt (BHVO-1) and an averaged depleted MORB. Except for $\mathrm{Ba}$, Th, and $\mathrm{U}$, lavas from Hole 758A have abundance ratios similar to those of the primitive mantle $(\mathrm{U}$ and $\mathrm{Pb}$ data are from Weis and Frey, this volume; $\mathrm{U}$ point for Site 758 is the average $\mathrm{U}$ content for lavas from Hole 758A). The lavas from Holes 756D and 757C are more enriched in incompatible elements. The plotted Hole $757 \mathrm{C}$ lava has a relatively high $\mathrm{Th}$ but anomalously low $\mathrm{Ti}$ and $\mathrm{P}$ content. These are characteristics of lavas from flow Units 757C-F18 and 757C-F19.

and $757 \mathrm{C}-\mathrm{F} 19$ are offset to lower ${ }^{206 \mathrm{~Pb}} / 204 \mathrm{~Pb}$ and ${ }^{207} \mathrm{~Pb} / 204 \mathrm{~Pb}$ (Weis and Frey, this volume), which is opposite to the trend expected from the addition of continental crust.

\section{CONCLUSIONS}

Although the geochemical data for the Leg 121 lavas require more than one compositionally and isotopically distinct parental magma at each drill site, lavas from each site share important characteristics. At Site 756 all the lavas have higher ${ }^{206} \mathrm{~Pb} / 204 \mathrm{~Pb}$ than the Kerguelen Archipelago lavas (Weis and Frey, this volume). At Site 757 we infer that all the lavas were derived from high- $\mathrm{Al}_{2} \mathrm{O}_{3}$, low total iron parental magmas that may have formed by melt-residue segregation at low pressure $(10 \mathrm{~kb})$. In contrast to the evidence for subaerial eruption at the other Ninetyeast Ridge drill sites, lavas from Site 758 erupted in a submarine environment; they did not erupt from a large volcanic edifice. Because of this observation and their relatively high $\mathrm{MgO}$ contents $(>8 \%)$, the magmas erupted at Site 758 may have had a simpler crustal fractionation history.

The significant geochemical differences among lavas recovered from each drill site on Ninetyeast Ridge and the geochemical differences between the Kerguelen Island and Ninetyeast Ridge lavas require important differences in source components. However, all of these lavas have a DUPAL isotopic signature, and their sources contained the mantle component, that contributes this isotopic signature. In addition to this presumed Kerguelen-Heard plume component, these sources contained variable amounts of (1) a MORB-related component (expressed mostly by ${ }^{87} \mathrm{Sr} / 86 \mathrm{Sr}$ and ${ }^{143} \mathrm{Nd} /{ }^{144} \mathrm{Nd}$ and especially by the relative abundance depletions of highly incompatible elements, such as $\mathrm{Ba}$, Th, and $\mathrm{La}$, in lavas from Site 758) and (2) a component with relatively high ${ }^{206} \mathrm{~Pb} / 204 \mathrm{~Pb}$ (expressed mostly by the relatively high ${ }^{206} \mathrm{~Pb} / 204 \mathrm{~Pb}$ ratios in lavas from Site 756), perhaps derived from the Amster-
dam-St. Paul plume (Dosso et al., 1988; Weis and Frey, this volume). The lavas from Ninetyeast Ridge contain no evidence for a continental lithosphere component related to the breakup of Gondwanaland. A better understanding of the role of these components in creating the eastern Indian Ocean seafloor requires additional geochemical study of (1) lavas from DSDP sites in this region, (2) recent lavas erupted along the largely unsampled portion of the Southeast Indian Ridge axis from the vicinity of St. Paul Island to the Australia-Antarctica Discordance, and (3) lavas from stratigraphic sequences in the Kerguelen Archipelago, St. Paul, and Amsterdam Islands. Also, the ongoing studies of lavas from the Kerguelen Plateau (Legs 119 and 120) will provide important constraints on the early evolution of the KerguelenHeard hot spot. Finally, we need to learn much more about Ninetyeast Ridge. For example, even with three ODP and four DSDP sites on Ninetyeast Ridge, the sampling density, on average, is only one site per $650 \mathrm{~km}$ of ridge length. Also, several types of fundamental information need to be obtained or improved; for example, what is the seismic structure of the ridge and what are the ages of adjacent oceanic crust east and west of the ridge. Does the detailed bathymetry indicate a chain of discrete, large volcanic centers, such as Hawaii, or was volcanism relatively continuous?

\section{ACKNOWLEDGMENTS}

Neutron irradiations were made at the MIT nuclear reactor. We thank Dr. P. Ila for help with the neutron activation analyses, N. G. Ware for assistance with the electron microprobe analyses, and Professor J. M. Rhodes for use of the University of Massachusetts XRF facility. We appreciate the constructive review comments of the editor, J. Alt, and two anonymous reviewers. This research was supported by USSAC grant (20250) and NSF Grant OCE8823028 . 


\section{REFERENCES}

Basaltic Volcanism Study Project, 1981. Basaltic Volcanism on the Terrestrial Planets: New York (Pergamon Press), 183-184.

Bass, M. N., 1976. Secondary minerals in oceanic basalt, with special reference to Leg 34, Deep Sea Drilling Project. In Yeats, R. S., Hart, S. R., et al., Init. Repts. DSDP, 34: Washington (U.S. Govt. Printing Office), 393-432.

Bence, A. E., Taylor, S. R., and Fisk, M., 1980. Major- and trace-element geochemistry of basalts from Ojin, Nintoku and Suiko seamounts of the Emperor Seamount Chain: DSDP-IPOD Leg 55. In Jackson, E. D., Koizumi, I., et al., Init. Repts. DSDP, 55: Washington (U.S. Govt. Printing Office), 599-605.

Bienvenu, P., Bougault, H., Joron, J. L., Treuil, M., and Dmitriev, L., 1990. MORB alteration: rare-earth element/non-rare-earth hydromagmaphile element fractionation. Chem. Geol., 82:1-14.

Boynton, W. V., 1984. Cosmochemistry of the rare earth elements: meteorite studies. In Henderson, P. (Ed.), Rare Earth Element Geochemistry: New York (Elsevier), 63-114.

Budahn, J. R., and Schmitt, R. A., 1985. Petrogenetic modeling of Hawaiian tholeiitic basalts: a geochemical approach. Geochim. Cosmochim. Acta, 49:67-87.

Cambon, P., Joron, J. L., Bougault, H., and Treuil, M., 1980. Leg 55, Emperor Seamounts: trace elements in transitional tholeiites, alkali basalts and hawaiites-mantle homogeneity or heterogeneity and magmatic processes. In Jackson, E. D., Koizumi, I., et al., Init. Repts. DSDP, 55: Washington (U.S. Govt. Printing Office), 585-597.

Chen, C.-Y., and Frey, F. A., 1985. Trace element and isotopic geochemistry of lavas from Haleakala Volcano, East Maui, Hawaii: implications for the origin of Hawaiian basalts. J. Geophys. Res., 90:8743-8768.

Clague, D. A., 1987. Hawaiian alkaline volcanism. In Fitton, J. G., and Upton, B.G.J. (Eds.), Alkaline Igneous Rocks. Geol. Soc. Spec. Publ. London, 30:227-252.

Clague, D. A., and Dalrymple, G. B., 1987. The Hawaiian-Emperor Volcanic Chain. Part 1: geologic evolution. Geol. Surv. Prof. Pap. U. S., 1350:5-54.

Clague, D. A., and Frey, F. A., 1980. Trace-element geochemistry of tholeiitic basalts from Site 433C, Suiko seamount. In Jackson, E. D., Koizumi, I., et al., Init, Repts. DSDP, 55: Washington (U.S. Govt. Printing Office), 559-569.

Davies, H., Sun, S. S., Frey, F. A., Gautier, I., McCulloch, M., Price, R., Bassias, Y., Klootwijk, C. T., and Leclaire, L., 1989. Basalt basement from the Kerguelen Plateau and the trail of a Dupal plume. Contrib. Mineral. Petrol., 103:457-469.

Dehn, J., Schmincke, H.-U., and Leg 121 Shipboard Party, 1989. The Toba ash and older tephra layers of the north eastern Indian Ocean ODP Leg 121. N. M., Bur. Mines Miner. Resour., 131:69. (Abstracts of IAVCEI General Assembly on Continental Magmatism)

Dosso, L., Bougault, H., Beuzart, P., Calvez, J.-Y., and Joron, J.-L., 1988. The geochemical structure of the South-East Indian Ridge. Earth Planet. Sci. Lett., 88:47-59.

Duncan, R. A., 1978. Geochronology of basalts from the Ninetyeast Ridge and continental dispersion in the eastern Indian Ocean. J. Volcanol. Geotherm. Res., 4:283-305.

Falloon, T. J., and Green, D. H., 1988. Anhydrous partial melting of peridotite from 8 to $35 \mathrm{~kb}$ and the petrogenesis of MORB. J. Petrol. Spec. Lithosphere Iss., 379-414.

Feigenson, M. D., 1986. Constraints on the origin of Hawaiian lavas. $J$. Geophys. Res., 91:9383-9393.

Feigenson, M. D., and Spera, F. J., 1981. Dynamical model for temporal variation in magma type and eruption interval at Kohala volcano, Hawaii. Geology, 9:531-533.

Frey, F. A., Dickey, J. S., Jr., Thompson, G., and Bryan, W. B., 1977. Eastern Indian Ocean DSDP sites: correlations between petrography, geochemistry and tectonic setting. In Heirtzler, J. R., and Sclater, J. G. (Eds.), A Synthesis of Deep Sea Drilling in the Indian Ocean: Washington (U.S. Govt. Printing Office), 189-257.

Frey, F. A., and Roden, M. R., 1987. The mantle source for the Hawaiian islands: constraints from the lavas and ultramafic inclusions. In Menzies, M., and Hawkesworth, C. J. (Eds.), Mantle Metasomatism: London (Academic Press), 423-463.
Frey, F. A., Wise, W. S., Garcia, M. O., West, H., Kwon, S.-T., and Kennedy, A., 1990. Evolution of Mauna Kea volcano, Hawaii: petrologic and geochemical constraints on postshield volcanism. $J$. Geophys. Res., 95:1271-1300.

Gautier, I., 1987. Les basaltes des Iles Kerguelen [Thèse de doctorat]. Univ. de Paris VI.

Gautier, I., Frey, F. A., and Weis, D., 1989. The differentiated lavas of the Southeast Province of Kerguelen Archipelago (South Indian Ocean). Eos, Trans. Am. Geophys. Union, 70:1384. (Abstract)

Gautier, I., Weis, D., Mennessier, J.-P., Vidal, P., Giret, A., and Loubet, M., 1990. Petrology and geochemistry of the Kerguelen Archipelago basalts: evolution of the mantle sources from ridge to intraplate position. Earth Planet. Sci. Lett., 100:59-76.

Gunn, B. M., 1971. Trace element partition during olivine fractionation of Hawaiian basalt. Chem. Geol., 8:13.

Hart, S. R., 1984. A large scale isotope anomaly in the Southern Hemisphere mantle. Nature, 309:753-757.

Hickson, C. J., and Juras, S. J., 1986. Sample contamination by grinding. Can. Mineral., 24:585-589.

Hofmann, A. W., Jochum, K. P., Seufert, M., and White, W. M., 1986. $\mathrm{Nb}$ and $\mathrm{Pb}$ in oceanic basalts: new constraints on mantle evolution. Earth Planet. Sci. Lett., 79:33-45.

Honnorez, J., 1981. The aging of the oceanic crust at low temperature. In Emiliani, C. (Ed.), The Sea (vol. 7): New York (Wiley), 525-587.

Hughes, T. C., and Hannaker, P., 1978. The determination of carbon and hydrogen in geological materials by thermal decomposition. Chem. Geol., 22:331-339.

Ila, P., and Frey, F. A., 1984. Utilization of neutron activation analysis in the study of geologic materials. Atomkernenerg. Kerntect., 44: $710-716$.

Jackson, E. D., Koizumi, I., et al., 1980. Init. Repts DSDP, 55: Washington (U.S. Govt. Printing Office).

Joron, J. L., Briqueu, L., Bougault, H., and Treuil, M., 1980. East Pacific Rise, Galapagos spreading center and Siqueiro Fracture Zone. Hydromagmaphile elements: a comparison with the North Atlantic. In Rosendahl, B. R., Hekinian, R., et al., Init. Repts. DSDP, 54: Washington (U.S. Govt. Printing Office), 725-735.

Klein, E. M., and Langmuir, C. H., 1987. Global correlations of ocean ridge chemistry with axial depth and crustal thickness. J. Geophys. Res., 92:8089-8115.

Kurz, M. D., and Kammer, D. P., 1991. Isotopic evolution of Mauna Loa Volcano. Earth Planet. Sci. Lett., 103:257-269.

Le Bas, M. J., Le Maitre, R. W., Streckeisen, A., and Zanettin, B., 1986. A chemical classification of volcanic rocks based on the total alkalisilica diagram. J. Petrol., 27:745-750.

LeRoex, A. P., Dick, H.J.B., and Fisher, R. L., 1989. Petrology and geochemistry of MORB from $25^{\circ} \mathrm{E}$ to $46^{\circ} \mathrm{E}$ along the Southwest Indian Ridge: evidence for contrasting styles of mantle enrichment. J. Petrol., 30:947-986.

Loubet, M., Sassi, R., and Di Donato, G., 1988. Mantle heterogeneities: a combined isotope and trace element approach and evidence for recycled continental crust materials in some OIB sources. Earth Planet. Sci. Lett., 89:299-315.

Macdonald, G. A., and Katsura, J., 1964. Chemical composition of Hawaiian lavas. J. Petrol., 5:82-133.

McDonough, W. F., and Sun, S.-S., 1985. Isotopic and geochemical systematics in Tertiary-Recent basalts from south eastern Australia and implications for the evolution of the sub-continental lithosphere. Geochim. Cosmochim. Acta, 49:2051-2067.

Miyashiro, A., 1974. Volcanic rock series in island arcs and active continental margins. Am. J. Sci., 274:321-355.

Morrison, M. A., and Thompson, R. N., 1986. The origin and distribution of ore minerals within the oceanic crust. In Cronan, D. S. (Ed.), Sedimentation and Mineral Deposits in the Southwestern Pacific Ocean: London (Academic Press), 263-305.

Newman, A.C.D., and Brown, G., 1987. The chemical constitution of clays. In Newman, A.C.D. (Ed.), Chemistry of Clays and Clay Minerals: Mineral. Soc. Monogr., 6:1-128.

Price, R. C., Kennedy, A. K., Riggs-Sneeringer, M., and Frey, F. A., 1986. Geochemistry of basalts from the Indian Ocean triple junction: implications for the generation and evolution of Indian Ocean ridge basalts. Earth Planet. Sci. Lett., 78:379-396. 
Rhodes, J. M., 1983. Homogeneity of lava flows: chemical data for historic Mauna Loan eruptions. Proc. 13th Lunar Planet. Sci. Conf. 13th (Pt. 2). J. Geophys. Res., 88 (Suppl.):A869-A879.

Royer, J. Y., and Sandwell, D. T., 1989. Evolution of the eastern Indian Ocean since the Late Cretaceous: constraints from GEOSAT altimetry. J. Geophys. Res., 94:13755-13782.

Schilling, J. G., Thompson, G., Kingsley, R., and Humphris, S., 1985. Hot spot-migrating ridge interaction in the South Atlantic. Nature, 313:187-191.

Schubert, G., and Sandwell, D., 1989. Crustal volumes of the continents and of oceanic and continental submarine plateaus. Earth Planet. Sci. Lett., 92:234-246.

Seyfried, and Bischoff, 1979. Low temperature basalt alteration by seawater: an experimental study at $70^{\circ} \mathrm{C}$ and $150^{\circ} \mathrm{C}$. Geochim. Cosmochim. Acta, 43:1937-1947.

Shapiro, L., and Brannock, W. W., 1962. Rapid analyses of silicate, carbonate and phosphate rocks. U.S. Geol. Survey Bull., 1144-A.

Shipboard Scientific Party, 1989a. Ninetyeast Ridge summary. In Peirce, J., Weissel, J., et al., Proc. ODP, Init. Repts., 121: College Station, TX (Ocean Drilling Program), 517-537.

1989b. Site 756. In Peirce, J., Weissel, J., et al., Proc. ODP, Init. Repts., 121: College Station, TX (Ocean Drilling Program), 259-303.

1989c. Site 757. In Peirce, J., Weissel, J., et al., Proc. ODP, Init. Repts., 121: College Station, TX (Ocean Drilling Program), 305-358.

1989d. Site 758. In Peirce, J., Weissel, J., et al., Proc. ODP, Init. Repts., 121: College Station, TX (Ocean Drilling Program), 359-453.

Stille, P., Unruh, D. M., and Tatsumoto, M., 1986. Pb, Sr, Nd, and Hf isotopic constraints on the origin of Hawaiian basalts and evidence for a unique mantle source. Geochim. Cosmochim. Acta, 50:23032319.

Storey, M., Saunders, A. D., Tarney, J., Gibson, A. L., Norry, M. J., Thirwall, M. F., Leat, P., Thompson, R. N., and Menzies, M. A., 1989. Contamination of Indian Ocean asthenosphere by the KerguelenHeard mantle plume. Nature, 338:574-576.

Storey, M., Saunders, A. D., Tarney, J., Leat, P., Thirlwall, M. F., Thompson, R. N., Menzies, M. A., and Marriner, G. F., 1988. Geochemical evidence for plume-mantle interactions beneath Kerguelen and Heard islands, Indian Ocean. Nature, 336:371-374.
Sun, S.-S., and McDonough, W. F., 1989. Chemical and isotopic systematics of oceanic basalts: implications for mantle composition and processes. In Saunders, A. D., and Norry, M. J. (Eds.), Magmatism in the Ocean Basins. Geol. Soc. Spec. Publ. London, 42:313-345.

Thompson, G., 1984. Basalt-seawater interaction. In Rona, P. A., Bostrom, K., Laubier, L., and Smith, K. L. (Eds.), Hydrothermal Processes at Seafloor Spreading Centers: New York (Plenum), 225-278.

Thompson, G., Bryan, W. B., Frey, F. A., and Sung, C. M., 1974. Petrology and geochemistry of basalts and related rocks from Sites $214,215,216$, DSDP Leg 22, Indian Ocean. In von der Borch, C. C., Sclater, J. G., et al., Init. Repts. DSDP, 22: Washington (U.S. Govt. Printing Office), 459-468.

Ware, N. G., 1981. Computer programs and calibration with PIBS technique for quantitative electron probe analysis using a lithium-drifted silicon detector. Comput. Geosci., 7:167-184.

Weaver, B. L., Wood, D. A., Tarney, J., and Joron, J.-L., 1986. Role of subducted sediment in the genesis of ocean-island basalts: geochemical evidence from South Atlantic islands. Geology, 14:275-278.

Weis, D., Bassias, Y., Gautier, I., and Mennesier, J.-P., 1989a. DUPAL anomaly in existence $115 \mathrm{Ma}$ ago: evidence from isotopic study of the Kerguelen Plateau (South Indian Ocean). Geochim. Cosmochim. Acta, 53:2125-2131.

Weis, D., Beaux, J.-F., Gautier, I., Giret, A., and Vidal, P., 1989b. Kerguelen Archipelago: geochemical evidence for recycled material. In Hart, S. R., and Gulen, L. (Eds.), Crust/Mantle Recycling at Convergence Zones. NATO ASI Series: Amsterdam (Kluwer Academic Press), 59-63.

Weis, D., Mennessier, J.-P., Gautier, I., Cantagrel, J.-M., and Vidal, P., 1987. Géochimie isotopique des Terres Australes (Archipel des îles Kerguelen). Actes Coll. Recherche Française dans les Terres Australes. Strasbourg (CNFRA), 357-368.

West, H. B., Gerlach, D. C., Leeman, W. P., and Garcia, M. O., 1987. Isotopic constraints on the origin of Hawaiian lavas from the Maui Volcanic Complex, Hawaii. Nature, 330:216-220.

Date of initial receipt: 19 March 1990

Date of acceptance: 14 November 1990 Ms 121B-163 


\section{APPENDIX A}

\section{DESCRIPTION OF ROCKS AND THIN SECTIONS FROM SITES 756, 757, AND 758}

HLD is the probe log number of the sample.

\section{Site 756}

All samples from the Site 756 cores are finely holocrystalline, sparsely plagioclase-phyric, sparsely amygdaloidal, moderately altered basalt.

\section{Sample 121-756C-10N-1,32-36 cm, [HLD 3/106, 3/111-2, 5/5], flow Unit $756 C-F 1$}

Plagioclase-microphyric holocrystalline basalt; titanomagnetite and ilmenite to $0.03 \mathrm{~mm}, 5 \%$; rare amygdules $0.1-0.3 \mathrm{~mm}$ with smectite around zeolite and some vesicles partly filled with calcite; veinlet of zeolite and calcite and opaque material (Mn oxides?).

Plagioclase microphenocryst $(0.2 \mathrm{~mm})$ is $\mathrm{An}_{66}$ to $\mathrm{An}_{49} \mathrm{Or}_{3}$, groundmass plagioclase is $\mathrm{An}_{60} \mathrm{Or}_{1.5}$. Clinopyroxene $(0.05 \mathrm{~mm})$ is $\mathrm{Fs} 20 \%$.

\section{Sample 121-756C-10N-3, $57 \mathrm{~cm}$, [HLD 5/5], flow Unit 756C-F]}

Sparsely microphyric fine holocrystalline? basalt, moderately altered, zoned plagioclase phenocrysts to $0.6 \mathrm{~mm}$; mesostasis is pale brown smectite.

Sample 121-756C-12N-1, 22-26 cm, [HLD 3/106, 121-3, 143, 5/5], flow Unit $756 C-F 2$

Similar to preceding Sample $121-756 \mathrm{C}-10 \mathrm{~N}-3,57 \mathrm{~cm}$, but coarser grained and more altered (much limonite). Sparsely plagioclase-microphyric holocrystalline? basalt with $20 \%-25 \%$ smectite after groundmass and after plagioclase microphenocrysts; zeolite veinlet.

Plagioclase microphenocrysts and groundmass are $\mathrm{An}_{66}$; clinopyroxene is Fs $13 \%$; ilmenite blades to $0.08 \mathrm{~mm}$, and rare titanomagnetite.

\section{Sample 121-756D-4R-1, 35-39 cm, [HLD 3/106, 5/7], flow Unit 756D-FI}

Similar to Sample $121-756 \mathrm{C}-12 \mathrm{~N}-1,22-26 \mathrm{~cm}$, but finer. Sparsely plagioclase-glomerophyric basalt (glomerocrysts to $1.5 \mathrm{~mm}$ ), much opaque minerals, much alteration $(70 \%)$, zeolitic amygdules $(<5 \%)$.

\section{Sample 121-756D-4R-1, 85-88 cm, [HLD 5/7], flow Unit 756D-F2}

Finer, sparsely plagioclase-microphyric, vesicular, holocrystalline basalt, $30 \%$ altered. Vesicles (15\%) amoeboid shapes to $1.5 \mathrm{~mm}$. Plagioclase microphenocrysts and most groundmass altered; groundmass laths $0.2 \mathrm{~mm}$.

\section{Sample 121-756D-5R-1, 75-79 cm, [HLD 5/7], flow Unit 756D-F2}

Similar to preceding sample: sparsely plagioclase-phyric, sparsely amygdaloidal, $40 \%$ altered, fine-grained holocrystalline basalt; microphenocrysts of plagioclase to $0.6 \mathrm{~mm}$, groundmass plagioclase to $0.3 \mathrm{~mm}$.

\section{Sample 121-756D-6R-1, 6-10 cm, [HLD 5/7], flow Unit 756D-F4}

Similar to preceding samples: sparsely amygdaloidal fine-grained holocrystalline basalt; groundmass laths altered; calcite veinlet; no vesicles.

\section{End of limonitic, brown, oxidized alteration (saponite-glauconite). Start of green-black color (Fe-rich saponite), and some brown. \\ Sample 121-756D-6R-2, 9-13 cm, [HLD 4/154-5, 159-60, 165-7, 5/7], flow Unit $756 D-F 5$}

Plagioclase-phyric (phenocrysts to $1.5 \mathrm{~mm}, 5 \%$ ), rarely glomerophyric (plagioclase-clinopyroxene), amygdaloidal (Fe-saponite) (5\%), holocrystalline basalt; groundmass plagioclase laths to $0.2 \mathrm{~mm}$, clinopyroxene in groundmass mostly altered.

Clinopyroxene $(0.25 \mathrm{~mm})$ is zoned from Fs $13 \%$ to Fs $19 \%$, groundmass clinopyroxene is Fs $21 \%-27 \%$.

Megaplagioclase is $\mathrm{An}_{83}$ zoned to $\mathrm{An}_{37} \mathrm{Or}_{3}$ on rim, $\mathrm{An}_{81} 20 \mu \mathrm{m}$ from rim; groundmass plagioclase is $\mathrm{An}_{61}$ zoned to $\mathrm{An}_{47}$.

\section{Sample 121-756D-6R-2, $13 \mathrm{~cm}$, [HLD 5/7]}

Contact between brown limonitic amygdaloidal plagioclase-phyric basalt with saponite-glauconite mixed clay and the black nonamygdaloidal plagioclase-phyric basalt with Fe-rich saponite. Amygdales in brown basalt are filled with interstratified saponite-glauconite. Calcite vein near contact.

\section{Sample 121-756D-7R-1, 100-104 cm, [HLD 5/9], flow Unit 756D-F6}

Sparsely plagioclase (to $1 \mathrm{~mm}$ ) and clinopyroxene (to $0.5 \mathrm{~mm}$ ) phyric basalt, sparsely amygdaloidal (smectite); groundmass laths to $0.2 \mathrm{~mm}$, some groundmass clinopyroxene; about $30 \%$ altered.

Sample 121-756D-7R-3, 50-54 cm, [HLD 4/138-142, 186, 5/5, 9], flow Unit $756 D-F 6$

Sparsely glomerophyric finely holocrystalline altered flow-textured basalt with plagioclase microphenocrysts to $0.5 \mathrm{~mm}$ and groundmass laths to $0.3 \mathrm{~mm}$; rare clinopyroxene zoned phenocrysts to $2 \mathrm{~mm}$; about $7 \%$ amygdules $0.2-0.9$ $\mathrm{mm}$; calcite veinlet. Alteration to brown color on one side of calcite veinlet (interstratified saponite-glauconite, moderate birefringence) and to greenblack color on other side of veinlet (Fe-rich saponite). No opaque minerals preserved.

Plagioclase is zoned $\mathrm{An}_{78-62} \mathrm{Or}_{0.3-0.8}$, clinopyroxene augite (note $\mathrm{Cr}_{2} \mathrm{O}_{3}$ to $0.7 \%$ ); green-black Fe-rich saponite has $2 \% \mathrm{Na}_{2} \mathrm{O}$ and $<0.2 \% \mathrm{~K}_{2} \mathrm{O}$; brown saponite-glauconite has $\mathrm{Na}_{2} \mathrm{O}$ near $1 \%$ and $\mathrm{K}_{2} \mathrm{O} 2.5 \%-3.3 \%$. Green-black smectite confirmed by XRD (J. Kamprad, BMR, 1989), Fe-rich saponite from mineral chemistry (see Appendix B).

\section{Sample 121-756D-7R-4, 118-122 cm, [HLD 5/9], flow Unit 756D-F6}

Hematitic red-brown $30 \%$ altered holocrystalline basalt, sparsely amygdaloidal; microphenocryst laths $0.5 \mathrm{~mm}$ and groundmass laths $0.2 \mathrm{~mm}$; some clinopyroxene preserved.

\section{Sample 121-756D-8R-1, 20-23 cm, [HLD 3/133, 5/9], flow Unit 756D-F7}

Like flow Unit 756D-F1 basalt and similar to Sample 121-756D-7R-4, $118-122 \mathrm{~cm}$, but much finer, more amygdules, and more altered.

Amygdaloidal, finely holocrystalline, hematitic, very altered basalt with clinopyroxene and plagioclase in groundmass and smectite, zeolite, calcite, and opaque material in amygdules and veins.

Groundmass plagioclase is $\mathrm{An}_{62}$ and $\mathrm{An}_{69}$, groundmass clinopyroxene is Fs $13 \%$ and $24 \%$, some ilmenite (blade).

\section{Sample 121-756D-9R-1, 56-60 cm, [HLD 5/9], flow Unit 756D-F9}

Brown, sparsely plagioclase-glomerophyric (laths to $0.5 \mathrm{~mm}$ ), holocrystalline basalt with possible pseudomorphs after olivine (but not distinctive crystal shapes). Groundmass plagioclase laths to $0.2 \mathrm{~mm}$. Twenty percent disseminated red-brown alteration.

\section{Sample 121-756D-9R-2, 21-24 cm, [HLD 4/162-3, 169-71, 5/11], flow Unit $756 D-F 9$}

Green-black sparsely plagioclase-phyric basalt, phenocrysts to $1 \mathrm{~mm}$, groundmass laths $0.2 \mathrm{~mm}$, some clinopyroxene; $30 \%$ black smectite (Fe-rich saponite) disseminated in groundmass.

Plagioclase phenocryst is $\mathrm{An}_{74-83}$ with reaction rim of $\mathrm{An}_{66 \rightarrow 60}$. Groundmass plagioclase is $\mathrm{An}_{32}$ and $\mathrm{An}_{66}$, groundmass clinopyroxene is $\mathrm{Fs}$ $16 \% \rightarrow$ Fs $23 \%$ and Fs $13 \% \rightarrow$ Fs $38 \%$; opaque minerals mostly ilmenite but some titanomagnetite.

\section{Sample 121-756D-10R-1, 99-103 cm, [HLD 5/111], flow Unit 756D-F12}

Sparsely plagioclase and glomerophyric brown basalt with plagioclase and clinopyroxene in groundmass. Olivine? pseudomorph associated with plagioclase phenocryst. Limonitic brown smectitic (probably saponiteglauconite) alteration in parallel veinlets (microfractures) and amygdules.

\section{Sample 121-756D-10R-3, 58-63 cm, [HLD 4/187, 5/11], flow Unit $756 D-F 12$}

Sparsely plagioclase-phyric green-brown basalt; prominent parallel veinlets of limonitic smectite alteration (microfractures, subhorizontal?). Coarser plagioclase laths at location of probable former segregation vesicle. Groundmass laths to $0.2 \mathrm{~mm}$.

Plagioclase microphenocryst $(0.6 \mathrm{~mm})$ is zoned from $\mathrm{An}_{66}$ (core) to $\mathrm{An}_{52} \mathrm{Or}_{2}$ (rim); groundmass plagioclase is $\mathrm{An}_{62}$; clinopyroxene microphenocryst is Fs $13 \% \rightarrow$ Fs $17 \%$. 


\section{Sample 121-756D-11R-1, 102-106 cm, [HLD 5/11], flow Unit 756D-F13}

Red-brown plagioclase-phyric (to $1 \mathrm{~mm}$ ) basalt with large vesicle (to $1 \mathrm{~mm}$ ) and quench or "chill" texture; groundmass notably finer at $0.1 \mathrm{~mm}$, much alteration. Smectite lining on vesicle.

$$
\begin{gathered}
\text { Sample 121-756D-12R-2, 6-8 cm, [HLD 3/106, 125, 5/13], flow Unit } \\
756 D-F 14
\end{gathered}
$$

Brown amygdaloidal $(15 \%)$ holocrystalline basalt, brown smectite in amygdules, amygdule to $1 \mathrm{~mm}$; groundmass laths to $0.2 \mathrm{~mm}$; some clinopyroxene in groundmass.

\section{Sample 121-756D-12R-2, 22-27 cm, [HLD 5/11], flow Unit 756D-F14}

Sparsely amygdaloidal and sparsely plagioclase-phyric finely holocrystalline basalt, phenocryst laths and glomerocrysts to $2 \mathrm{~mm}$, amygdules to $1.5 \mathrm{~mm}$. Amygdules are smectite with zeolite in shrinkage cracks. Rock is $15 \%-20 \%$ smectite.

Plagioclase phenocryst core $\mathrm{An}_{68}$. Plagioclase lath ( $0.1 \mathrm{~mm}$ ) rim $\mathrm{An}_{48} \mathrm{Or}_{3.5}$; groundmass clinopyroxene Fs $20 \%$.

\section{Sample 121-756D-12R-3, 139-143 cm, [HLD 5/13], flow Unit 756D-F14}

Green-black, sparsely amygdaloidal, sparsely plagioclase-phyric basalt. Dark smectite disseminated throughout; green celadonite? associated with smectite in amygdules.

\section{Site 757}

All of the samples from Holes 757B and 757C are crowded plagioclase porphyry with varying degrees of alteration (up to $80 \%$ alteration).

In the "barrel sheet" descriptions many flow units are noted as showing an increase in the proportion of plagioclase phenocrysts from 0 at the top of the flow to $25 \%$ at the bottom of the flow.

\section{Sample 121-757B-41X-1, 30-34 cm, [HLD 3/98, 4/72-4, 94, 5/15, 78], flow Unit $757 B-F 1$}

Typical crowded porphyry. Dark blue-green, relatively unaltered. Crowded porphyry of plagioclase glomerocrysts and megacrysts (to $10 \mathrm{~mm} ; 50 \%$ ) with reaction rims; inclusions of former melt(?) and clinopyroxene and alteration to $\mathrm{K}$-feldspar and chlorite. Plagioclase megacrysts $\mathrm{An}_{86}$ with $40-\mu \mathrm{m}$-wide reaction rim $\mathrm{An}_{82} \rightarrow \mathrm{An}_{55} \mathrm{Or}_{1}$. Groundmass plagioclase, $0.1 \mathrm{~mm}$, is $\mathrm{An}_{75}$. Groundmass clinopyroxene is Fs $11 \%$ to Fs $16 \%$. More ilmenite than titanomagnetite.

Amygdales 1-1.5 mm of smectite + zeolite. Some smectite after groundmass (total smectite about $15 \%$ ).

Photographs HLD 5/15, 78 show growth of megaplagioclase marked by inclusions.

\section{Sample 121-757B-42N-1,30-34 cm, [HLD 3/97, 4/93, 5/15, 79], flow Unit} $757 B-F 1$

Dark gray, unusual texture. Note segregation vesicles (photographed). Highly amygdaloidal crowded porphyry; some segregation vesicles (vesicles filled or partly filled with late-stage melt).

Megaplagioclase $30 \%$, groundmass $40 \%$, amygdales of calcite and smectite $30 \%$.

Plagioclase lath in groundmass is $\mathrm{An}_{54} \mathrm{Or}_{1}$, cf. plagioclase lath in segregation vesicle is $\mathrm{An}_{45} \mathrm{Or}_{2}$, which is probably not proof of fractionation. Best indication of fractionation is the high proportion of titanomagnetite and ilmenite in segregation vesicle. Clinopyroxene in groundmass is Fs $10 \%$.

Photographs HLD 5/15, 79 show segregation vesicles.

Start of crowded porphyry with large blebs of calcite and zeolite.

Sample 121-757B-43N-CC, 6-8 cm, [HLD 3/98, 5/15], flow Unit 757B-F2

Dark gray, fine- to medium-grained, holocrystalline, crowded with white amygdules; some 6-mm plagioclase phenocrysts seen.

Altered amygdaloidal crowded porphyry. Calcite and green chlorite/smectite in amygdales and in irregular blebs throughout groundmass (progressive replacement of groundmass). Megaplagioclase partly altered. olivine.

\section{Sample 121-757C-8R-1, 65-69 cm, [HLD 3/98, 5/17], flow Unit 757C-F1}

Altered amygdaloidal crowded porphyry, $>70 \%$ alteration. Most megaplagioclase now smectite. Amygdales $1.5-2.5 \mathrm{~mm}$, much calcite, also smectite and some zeolite. Irregular blebs of alteration are smectite-calcite with rim of hematite.

$$
\text { Start of typical crowded porphyry. }
$$

Sample 121-757C-8R-2, 132-136 cm, [HLD.3/106, 114-5, 5/17], flow Unit

$$
757 C-F 2
$$

Crowded porphyry. Megacrysts and glomerocrysts to $5 \mathrm{~mm}$, with reaction rims and apparently strongly zoned, chlorite and $\mathrm{K}$-feldspar alteration. Opaque materials are ilmenite and titanomagnetite.

Megaplagioclase $\mathrm{An}_{86}$ core and rim, $40 \%$, groundmass plagioclase is $\mathrm{An}_{73}-\mathrm{An}_{54}$; groundmass clinopyroxene is $\mathrm{Fs} 11 \%-13 \%$; smectite alteration $15 \%-20 \%$. Note analyses of inclusions (after glass) in megaplagioclase (HLD $3 / 115)$.

Sample 121-757C-9R-1, 105-109 cm, [HLD 3/106, 116-9, 142, 5/17], flow Unit $757 C-F 2$

Crowded plagioclase porphyry. Megaplagioclase to $6 \mathrm{~mm}$, zoned and reaction-rimmed with inclusions (1) after glass and (2) of fine clinopyroxene. Opaque materials ilmenite and titanomagnetite.

Megaplagioclase $40 \%$, groundmass $40 \%$, smectite $15 \%-20 \%$, and zeolite veins and blebs $5 \%$.

Megaplagioclase is zoned from $\mathrm{An}_{85}$ core to $\mathrm{An}_{51}$ rim, groundmass plagioclase is $\mathrm{An}_{65}, \mathrm{An}_{58}, \mathrm{An}_{41} \mathrm{Or}_{2}$; groundmass clinopyroxene is $\mathrm{Fs} 9 \%, 16 \%$, $20 \%$. Appendix B has analyses of "glass" inclusions in megaplagioclase. No former olivine.

Sample 121-757C-9R-2, 47-51 cm, [HLD 3/98, 4/75-7, 5/19, 80], flow Unit $757 C-F 2$

Green-brown, moderately altered, medium-grained, crowded plagioclase porphyry, plagioclase to $8 \mathrm{~mm}$, moderately altered, rare amygdales. Megaplagioclase is $\mathrm{An}_{81}$, that is, less calcic than in other samples with crowded plagioclase porphyry, with reaction rim $\mathrm{An}_{74}$ and $\mathrm{K}$-feldspar alteration between core and reaction rim. Groundmass plagioclase unusually sodic: $\mathrm{An}_{42} \mathrm{Or}_{1,7}$. Titanomagnetite and minor ilmenite. Ilmenite looks fresh but has anomalously high $\mathrm{MnO}(>4 \%)$. Green smectite or celadonite, and high-birefringence radiating fibrous mineral.

Megaplagioclase $60 \%$, groundmass $30 \%$, alteration $10 \%$.

Sample 121-757C-9R-3, 6-10 cm, [HLD 3/98, 4/95-105, 5/19], flow Unit $757 C-F 2$

Sparsely amygdaloidal, crowded plagioclase porphyry with calcite and smectite in amygdules, $0.3 \mathrm{~mm}$, also a bleb of calcite, $2 \mathrm{~mm}$. Megaplagioclase $40 \%$, groundmass $50 \%$, smectite + calcite $10 \%$.

Rim of megaplagioclase is $\mathrm{An}_{68}$ and core $\mathrm{An}_{87}-\mathrm{An}_{83}$. Shows irregular variation in composition across growth lines (Fig. 5). No former olivine.

$$
\begin{gathered}
\text { Sample 121-757C-9R-4, 38-42 cm, [HLD 3/106, 125-6, 5/19], flow Unit } \\
757 C-F 3
\end{gathered}
$$

Crowded plagioclase porphyry. Megaplagioclase to $7 \mathrm{~mm}$ shows growth rings (fine opaque materials), also alteration veinlets; megaplagioclase is $\mathrm{An}_{86}$ and same on rim; groundmass plagioclase is $\mathrm{An}_{77}$; groundmass clinopyroxene is Fs $8 \%$ but clinopyroxene included in megaplagioclase plagioclase (small 3 $\times 8 \mu \mathrm{m} \mathrm{rhomb}$ ) is Fs $31 \%$; opaque materials are titanomagnetite, no ilmenite.

Megaplagioclase $45 \%$, groundmass $40 \%$, alteration of groundmass (smectites, zeolites) $10 \%$, amygdales to $2 \mathrm{~mm}$ (smectite around calcite) $5 \%$.

\section{Sample 121-757C-9R-5, 34-38 cm, [HLD 3/98, 5/21], flow Unit 757C-F4}

Crowded plagioclase porphyry, amygdaloidal ( $2 \mathrm{~mm}$, zeolites). Equant plagioclase to $7 \mathrm{~mm}$. Hematitic alteration brown color.

Megaplagioclase $40 \%$, groundmass $40 \%$, smectite after groundmass $10 \%$, amygdales $10 \%$.

\section{Sample 121-757C-9R-5, 70-73 cm, [HLD 3/98, 4/183-5, 5/21], top of flow Unit $757 C-F 5$}

Not a crowded porphyry. Amygdaloidal, plagioclase-phyric holocrystalline basalt. Spectacular zeolites in amygdules $(20 \%-25 \%)$; plagioclase 
phenocrysts $2-3 \mathrm{~mm}, 5 \%$; groundmass $70 \%$. All plagioclase in groundmass is altered. Hematitic alteration. No calcite.

Unusual plagioclase compositions: megaplagioclase cores where fine inclusions are still preserved are primary bytownite (as determined by albite and carlsbad-albite twinning extinction angles); those that have no inclusions have small extinction angles and are oligoclase $\mathrm{An}_{22} \mathrm{Or}_{6}$, as determined by probe (but poor stoichiometry); that the oligoclase is a lower temperature replacement is indicated by the lack of $\mathrm{FeO}, \mathrm{MgO}$ impurities; one $0.1-\mathrm{mm}$ plagioclase lath also is $\mathrm{An}_{27} \mathrm{Or}_{5.5}$. Groundmass clinopyroxene is normal Fs $11 \%-13 \%$.

Anomalously high whole-rock $\mathrm{Sr}$ content is surprising in view of lack of calcite, but could be due to Ca-zeolite, 2V 50(-), rhombic sections with moderate birefringence, scolecite?

Low content of plagioclase phenocrysts, together with replacement of former bytownite by oligoclase and by smectite, and extreme development of zeolites and alteration of groundmass probably explain high $\mathrm{Na}$ and anomalously low $\mathrm{Ca}$ in whole-rock analysis.

\section{Sample 121-757C-9R-6, 102-106 cm, [HLD 3/99, 4/189-191, 5/21], flow Unit $757 C-F 5$}

Typical crowded porphyry. Mottled green-brown crowded plagioclase porphyry with discontinuous veinlets and pockets of alteration (smectite around calcite) up to $6 \mathrm{~mm}$ across and smectite in groundmass.

Megaplagioclase $40 \%$, groundmass $30 \%$, smectite and calcite $30 \%$. Megaplagioclase euhedra with growth rings are $\mathrm{An}_{92}$ to $\mathrm{An}_{90}$ within $0.1 \mathrm{~mm}$ of rim, then zoned to $\mathrm{An}_{54.5}$; groundmass plagioclase is $\mathrm{An}_{65}$ zoned to $\mathrm{An}_{55}$; groundmass clinopyroxene Fs $11 \% \rightarrow$ Fs $17 \%$. No former olivine.

\section{Sample 121-757C-9R-7, 78-82 cm, [HLD 3/99, 4/184-5, 5/23], flow Unit $757 C-F 5$}

Crowded plagioclase porphyry. Prominent calcite grains associated with plagioclase phenocrysts are pseudomorphs after olivine. Megaplagioclase $\mathrm{An}_{88}$ to within $0.5 \mathrm{~mm}$ of rim then steadily zoned to $\mathrm{An}_{31} \mathrm{Or}_{3}$; groundmass lath is zoned from $\mathrm{An}_{75}$ to $\mathrm{An}_{35} \mathrm{Or}_{2}$; groundmass clinopyroxene is $\mathrm{Fs} 13 \%$ on rim.

Megaplagioclase to $5 \mathrm{~mm}, 45 \%$; groundmass $35 \%$; alteration (calcite + celadonite + hematitic clay) $20 \%$.

\section{Sample 121-757C-9R-8, 54-59 cm, [HLD 3/99, 5/23, 89-92], bottom of flow Unit $757 C-F 5$} brown.

Green-brown alteration concentrated at veinlet is zoned, green around

Crowded plagioclase porphyry. Megaplagioclase $1-5 \mathrm{~mm}$ has reaction rims and some $\mathrm{K}$-feldspar alteration. Rare amygdales $(0.5-1 \mathrm{~mm}$, smectite). Irregular veinlike cavities are site of coarser grained late-crystallized andesine plagioclase $\mathrm{An}_{45} \pm \mathrm{An}_{40}$ and $\mathrm{An}_{53}$ to $\mathrm{An}_{31} \mathrm{Or}_{2}$. Next to crystallize (toward center of crack) was chloritelike smectite, followed (center of veinlet) by $\mathrm{Na}-\mathrm{Ca}-\mathrm{Al}$ zeolite (sketched HLD p. 5/89). Groundmass plagioclase in the remainder of the thin section is $\mathrm{An}_{52-55}$.

Megaplagioclase $40 \%$, groundmass $30 \%$, alteration of hematitic smectite and zeolite $30 \%$.

Evidence noted of late magmatic fluids in this sample, such as a segregation vesicle. Strongly zoned laths of andesine-oligoclase project into former fissure now filled with smectite and zeolite (in that order).

\section{Sample 121-757C-10R-1, 86-90 cm, [HLD 3/99, 4/69-71, 5/23, 81;} photograph of zoned megaplagioclase], flow Unit $757 C$-F6

Greenish brown with cuspate cavity fillings (white $+\mathrm{MnO}$ ?). Crowded plagioclase porphyry. Zoned plagioclase megacrysts to $7 \mathrm{~mm}$ with inclusions and K-feldspar alteration. Amygdales (zeolite, calcite) and irregular blebs of alteration (smectite around $\mathrm{Na}, \mathrm{Al}$, and $\mathrm{Si}$ and around calcite). Ilmenite (rare) and titanomagnetite. Megaplagioclase is $\mathrm{An}_{86}$ zoned to $\mathrm{An}_{47} \mathrm{Or}_{1}$; groundmass plagioclase is $\mathrm{An}_{67} ; \mathrm{K}$-feldspar alteration of megaplagioclase; groundmass clinopyroxene is Fs $11 \% \rightarrow$ Fs $19 \%$. Chloritic smectite with Na zeolite in core of cavities, also calcite. Some amygdules are calcite and some zeolite.

Megaplagioclase $50 \%$, groundmass $25 \%$, smectite-zeolite-calcite alteration $25 \%$.
Start of high proportion of zeolite blebs (amygdules and as replacements).

Sample 121-757C-10R-2, 33-37 cm, [HLD 3/99, 5/25], flow Unit 757C-F6

Pale brown crowded plagioclase porphyry, megaplagioclase to $5 \mathrm{~mm}$ as laths and equant euhedra; very altered, with zeolites in amygdales and irregular blebs to $7 \mathrm{~mm}$; most groundmass altered to clay minerals.

Megaplagioclase $30 \%$, altered groundmass (clay) $40 \%$, zeolite $30 \%$. Cazeolite, scolecite, confirmed by XRD (J. Kamprad, BMR, 1989).

\section{Sample 121-757C-10R-2, 66-70 cm, [HLD 3/99, 5/25, 123], flow Unit} $757 C-F 7$, could be the same as flow Unit $757 C-F 6$

Crowded plagioclase porphyry, large amygdules and large yellowish plagioclase phenocrysts, very altered.

Megaplagioclase $30 \%$; groundmass clinopyroxene $15 \%$; groundmass clay $15 \%$; zeolite in amygdules and blebs $30 \%$; calcite in blebs $10 \%$.

Megaplagioclase is remnants of bytownite in fields of $\mathrm{K}$-feldspar with minor Na-Ca zeolite. Groundmass clinopyroxene is Fs $10 \%-12 \%$.

Extreme alteration of plagioclase explains high $\mathrm{Na}$ and anomalously low $\mathrm{Ca}$ in whole-rock analysis.

Sample 121-757C-10R-3, 2-6 cm, [HLD 3/99, 5/25], flow Unit 757C-F8, could be the same as flow Unit $757 \mathrm{C}-\mathrm{F} 6$

Crowded plagioclase porphyry, megaplagioclase to $7 \mathrm{~mm}$, with zeolites and smectite alteration and possibly amygdules.

Megaplagioclase $20 \%$; groundmass $5 \%$; altered groundmass $35 \%$; zeolite with minor calcite $40 \%$.

\section{Sample 121-757C-10R-3, 83-87 cm, [HLD 3/99, 4/118-120, 5/27], flow Unit $757 C-F 9$}

Crowded plagioclase porphyry with rare clinopyroxene phenocrysts; $60 \%$ altered, includes large areas of zeolite, etc. Megaplagioclase to $6 \mathrm{~mm}$ with some $\mathrm{K}$-feldspar alteration. Megaplagioclase is $\mathrm{An}_{85}$ with rim of $\mathrm{An}_{87}$ and reaction rim of $\mathrm{Ca}$ zeolite; groundmass plagioclase is $\mathrm{An}_{64}$; clinopyroxene phenocryst core is Fs $14 \%$ and rim Fs $9 \%$; groundmass clinopyroxene is Fs $10 \%$. Celadonite? in some vesicles ( $\mathrm{Mg}, \mathrm{Al}, \mathrm{Si}, \mathrm{K}$, and $\mathrm{Fe} \mathrm{X}$-ray peaks).

Megaplagioclase $25 \%$, groundmass $15 \%$, altered groundmass (clay) $15 \%$, Na-Ca zeolite $25 \%$, calite $20 \%$.

Start of section of Hole $757 \mathrm{C}$ core with extreme alteration.

Sample 121-757C-11R-1, 67-72 cm, [HLD 3/106, 141-2, 5/27], flow Unit $757 C-F 10$

Crowded plagioclase porphyry, extremely altered. Common large grains of secondary $\mathrm{K}$-feldspar and $\mathrm{Na}$-Al-Si clay or zeolite; most large plagioclase grains are completely altered, were originally $40 \%$ of rock. Megaplagioclase remnants are $\mathrm{An}_{82}$. Relict reaction rim on former megaplagioclase is $\mathrm{An}_{65}$, and groundmass plagioclase is $\mathrm{An}_{61}$. Clinopyroxene in glomerocryst is Fs $10 \%$; groundmass clinopyroxene is Fs $16 \%$. Veining is smectite + zeolite + calcite.

Rock is $80 \%-90 \%$ altered.

Sample 121-757C-11R-1, 99-103 cm, [HLD 3/99, 5/27], flow Unit $757 C-F 11$, could be the same as flow Unit $757 C-F 10$

Extremely altered crowded plagioclase porphyry with rare clinopyroxene phenocrysts; rock was $30 \%$ megaplagioclase. Rock is $80 \%-90 \%$ made over to smectite and blebs of zeolite.

Sample 121-757C-11R-2, 10-14 cm, [HLD 3/106, 140-1, 5/29], basal contact of flow Unit $757 C-F 12$

Crowded plagioclase porphyry, amygdaloidal, was $30 \%$ megaplagioclase but is now $80 \%-90 \%$ altered. Clinopyroxene remnant in megaplagioclase is Fs $9 \%$ and in groundmass is Fs $10 \%$. Megaplagioclase core is $\mathrm{An}_{82}$, and groundmass plagioclase is $\mathrm{An}_{46} \mathrm{Or}_{3}$. Large amygdules are zeolite containing $\mathrm{Na}-\mathrm{Ca}-\mathrm{Al}-\mathrm{Si}$. Pseudomorph of clinopyroxene has celadonite.

\section{Sample 121-757C-IIR-2,51-56 cm, [HLD 3/99, 5/27, 119-122], flow Unit $757 C-F 13$}

Crowded plagioclase porphyry was $30 \%$ megaplagioclase but now $80 \%$ $90 \%$ altered. Large areas of zeolite. Rare clinopyroxene microphenocrysts (to $1 \mathrm{~mm})$.

Most of megaplagioclase is replaced by $\mathrm{Na}$ zeolite, analcime (prismatic, looks like albite, confirmed by XRD, J. Kamprad, BMR, 1989); there are 
remnants of bytownite and reaction rim ( $10 \mu \mathrm{m}$ across) of andesine $\mathrm{An}_{37} \mathrm{Or}_{1.6}$; groundmass plagioclase is also andesine $\mathrm{An}_{45} \mathrm{Or}_{1.5}$. Clinopyroxene phenocryst core is Fs $8 \%$ with rim Fs $16 \%$ and Fs 20\%; groundmass clinopyroxene is Fs $10 \% \rightarrow$ Fs $17 \%$

Replacement of megaplagioclase by Na zeolite and sodic composition of groundmass plagioclase both contribute to high $\mathrm{Na}$ and anomalously low $\mathrm{Ca}$ in whole-rock chemistry.

Typically extreme low-temperature hydrous alteration (K-feldspar and zeolite replacing megabytownite) occurs in rocks that show signs of anomalously high $\mathrm{Na} / \mathrm{Ca}$ in primary melt, that is, rocks that have sodic plagioclase as primary phase in groundmass.

\section{Sample 121-757C-11R-2, 94-97 cm, [HLD 3/100, 5/29], flow Unit $757 C-F 14$}

Similar to the preceding samples but finer grained. Pervasive alteration to pale greenish brown color, much amygdules.

Crowded plagioclase porphyry was $20 \%-30 \%$ megaplagioclase (to $5 \mathrm{~mm}$ ) but now $60 \%$ altered. Large blebs of zeolite. Rare clinopyroxene microphenocrysts.

Sample 121-757C-11R-3,49-54 cm, [HLD 3/100,5/31], flow Unit 757 C-F16

Dark brown, few amygdules, plagioclase phenocrysts less altered.

Crowded plagioclase porphyry, was 30\% megaplagioclase, now $80 \%-90 \%$ dark smectite alteration. Cluster of clinopyroxene microphenocrysts preserved.

Sample 121-757C-11R-3, 98-102 cm, [HLD 3/100, 5/31], flow Unit $757 C-F 17$

Paler brown, more amygdules, plagioclase phenocrysts more altered. Crowded plagioclase porphyry was $20 \%$ megaplagioclase (to $4 \mathrm{~mm}$ ) now $70 \%-80 \%$ altered to zeolite blebs, smectite, and calcite.

\section{End of Hole 757C section of core with extreme alteration and end of zeolite} blebs and of brown color.

Sample 121-757C-12R-1, 25-29 cm, [HLD 3/100, 4/156-7, 161-2, 167-8, 5/31], flow Unit 757C-F18

Dark green-gray with large plagioclase phenocrysts; similar to preceding samples but without amygdules and without brown (ferric oxides) alteration.

Plagioclase-phyric, phenocrysts $2-5 \mathrm{~mm}, 25 \%$; minor microphenocrysts clinopyroxene $(<1 \mathrm{~mm})$. Groundmass $75 \%$, most mafic minerals altered.

Megaplagioclase is $\mathrm{An}_{90}$ zoned to $\mathrm{An}_{87} 0.05 \mathrm{~mm}$ from rim; rim is zoned from $\mathrm{An}_{59}$ to $\mathrm{An}_{37} \mathrm{Or}_{2.2}$. Groundmass plagioclase is $\mathrm{An}_{52} \mathrm{Or}_{2} \rightarrow \mathrm{An}_{47} \mathrm{Or}_{2}$, also $\mathrm{An}_{55}$ and $\mathrm{An}_{46}$.

Clinopyroxene phenocrysts are Fs $11 \%$ zoned to Fs $14 \%$, Fs $7 \%-24 \%$, and Fs $9 \%-23 \%$. Groundmass clinopyroxene is Fs $13 \%$; fine clinopyroxene within megaplagioclase is Fs $13 \%$ and Fs $15 \%$. Note tholeitic trend for zoned and groundmass clinopyroxene (Fig. 5).

\section{Sample 121-757C-12R-1, 100-104 cm, [HLD 3/107, 138-140, 4/126-7, 5/33], flow Unit $757 C-F 18$}

Crowded plagioclase porphyry with some clinopyroxene phenocrysts and clinopyroxene inclusion in megaplagioclase. Titanomagnetite. All mafic minerals in groundmass are altered. Plagioclase phenocrysts $(2-5 \mathrm{~mm}) 25 \%$, groundmass $75 \%$.

\section{Sample 121-757C-12R-2, 0-5 cm, [HLD 3/100, 4/107-114, 5/33], flow Unit} 757 C-F 18

Brown crowded plagioclase porphyry similar to Sample 121-757C-12R-1, $100-104 \mathrm{~cm}$, but with sparse amygdules. Plagioclase phenocrysts are 2-6 mm and amygdules are 1-2 mm. Clinopyroxene microphenocrysts (rare) have reaction rims.

Megaplagioclase is $\mathrm{An}_{85}$ from core to just inside reaction rim; reaction rim is $0.05 \mathrm{~mm}$ across and is zoned from $\mathrm{An}_{64}$ to $\mathrm{An}_{45} \mathrm{Or}_{1}$; groundmass plagioclase is $\mathrm{An}_{58}$; note analysis of trapped "glass" in megaplagioclase (Appendix $\mathrm{B}$ ). Clinopyroxene phenocrysts are zoned asymmetrically from Fs $10 \%$ to Fs $23 \%$; much of core is Fs $19 \%$. Groundmass clinopyroxene is Fs $10 \% \rightarrow$ Fs $16 \%$.

Reverse zoning of clinopyroxene phenocryst Fs $18 \% \rightarrow 10 \% \rightarrow 13 \% \rightarrow$ $25 \%$ indicates magma mixing (Fig. 5).
Sample 121-757C-12R-2, 63-67 cm, [HLD 3/107, 134-5, 5/33], flow Unit $757 C-F 18$

Crowded plagioclase porphyry, amygdaloidal, rare clinopyroxene phenocrysts, $80 \%$ altered to dark smectite, zeolite blebs and ?amygdales, and K-feldspar.

Plagioclase phenocrysts to $5 \mathrm{~mm}, 25 \%$, are $\mathrm{An}_{87-84}$; groundmass plagioclase too altered; clinopyroxene phenocryst is Fs $8 \% \rightarrow$ Fs $12 \%$, rare groundmass clinopyroxene is Fs $18 \%$ (poor total); titanomagnetite and ilmenite. Very altered.

Start of moderately altered basalt.

Sample 121-757C-12R-3, 64-68 cm, [HLD 3/100, 3/35], flow Unit $757 C-F 19$

Brown, plagioclase-phyric (10\% plagioclase phenocrysts to $5 \mathrm{~mm}$ ) with rare clinopyroxene microphenocrysts, sparsely amygdaloidal and with blebs of zeolite and calcite. Groundmass, $75 \%$, is half altered to dark smectite.

\section{Sample 121-757C-12R-4, 24-29 cm, [HLD 3/100, 5/35, 92-99], flow Unit $757 C-F 19$}

Brown, plagioclase-phyric basalt; $15 \%$ megaplagioclase to $5 \mathrm{~mm}$, these are $50 \%$ altered; some small phenocrysts of clinopyroxene (to $1 \mathrm{~mm}$ ); a few zeolite amygdales; groundmass $90 \%$ altered to dark smectite.

Unusual whole-rock chemistry may be due to extreme alteration; former bytownite phenocrysts are $>50 \%$ replaced by $\mathrm{K}$-feldspar. However, there is also some indication of anomalous primary composition in that groundmass plagioclase and reaction rims on former phenocrysts are unusually sodic: andesine and oligoclase $\mathrm{An}_{49} \mathrm{Or}_{2}$ to $\mathrm{An}_{27} \mathrm{Or}_{2.5}$. Clinopyroxene, 0.6 to $0.9 \mathrm{~mm}$, is Fs $9 \%-25 \%$ and $\mathrm{Fs} 9 \%-19 \%$, and groundmass clinopyroxene is Fs $11 \%$.

Sample 121-757C-12R-4, 135-139 cm, [HLD 3/107, 129-30, 5/35], flow Unit 757C-F 19

Plagioclase-phyric basalt with $10 \%$ megaplagioclase; $35 \%$ large blebs zeolite and calcite; $55 \%$ groundmass of which $50 \%$ is altered.

Megaplagioclase is $\mathrm{An}_{87}$; reaction rim on megaplagioclase is $\mathrm{An}_{51}$; groundmass plagioclase is $\mathrm{An}_{51}$ and $\mathrm{An}_{56}$; anhedral plagioclase in groundmass is albite, $\mathrm{An}_{5}$, may be secondary. Groundmass clinopyroxene is $\mathrm{Fs} 11 \%-13 \%$.

Site 758

Sparsely plagioclase-phyric (and some clinopyroxene-phyric) with variable alteration and common development of fine sulfides (pyrite, chalcopyrite, etc).

Three elements were typically seen in thin section: (1) phenocrysts and microphenocrysts, (2) doleritic-textured (diabase-textured) holocrystalline groundmass, and (3) smectite interstitial in groundmass (replacement of ?glassy or ?microcrystalline material). In a few instances microcrystalline texture is preserved in smectite, but in most no primary texture was seen. Sulfides are common, always in smectite or in veinlets.

\section{Sample 121-758A-54R-2, 70-74 cm, [HLD 3/100, 4/83-88, 5/37], flow Unit} $758 A-F 1$.

A chill zone. Brownish black vitrophyric basalt with plagioclase phenocrysts and plagioclase-clinopyroxene glomerocrysts (15\%) in cryptocrystalline to glassy groundmass (now all smectite). Black pitchlike alteration (smectite) as irregular blebs and veinlets. Glassy selvage is now completely altered.

Plagioclase phenocryst, $0.7 \mathrm{~mm}$, is $\mathrm{An}_{85}$ (core) to $\mathrm{An}_{61}$ (rim); plagioclase $0.07 \mathrm{~mm}$ is $\mathrm{An}_{75}$ (core) to $\mathrm{An}_{80}$ (rim); K-feldspar (0.03 mm) noted in plagioclase phenocrysts,

Clinopyroxene $0.1-0.3 \mathrm{~mm}$ is Fs $9 \%-11 \%$, includes core Fs $11 \%$, rim Fs $9 \%$; some fine titanomagnetite.

\section{Sample 121-758A-55R-1, 30-34 cm, [HLD 3/100, 5/37], flow Unit 758A-FI}

Medium-grained basalt, black (smectite) in groundmass; irregular blebs of calcite rimmed by smectite.

Plagioclase-phyric holocrystalline basalt; $15 \%$ zoned phenocrysts to $3 \mathrm{~mm}$; $15 \%$ smectite in groundmass. Groundmass is plagioclase laths to $1 \mathrm{~mm}$ and stubby clinopyroxene. 


\section{Sample 121-758A-55R-2, 84-88 cm, [HLD 3/100, 5/37], flow Unit 758A-F1}

Similar to Sample 121-758A-55R-1, 30-34 cm. Medium-grained basalt with irregular black smectite alteration.

Plagioclase phenocrysts coarser (to $4 \mathrm{~mm}$ ). Large grain of pyrite ( $1.5 \mathrm{~mm}$ ) in smectite.

$$
\begin{aligned}
& \text { Sample 121-758A-55R-4, 11-15 cm, [HLD 3/101, 4/78, 5/39], flow Unit } \\
& 758 \mathrm{~A}-\mathrm{Fl}
\end{aligned}
$$

Similar: medium-grained dark basalt with black smectite blebs, intersertal smectite after microcrystalline groundmass; plagioclase-phyric (to $3 \mathrm{~mm}$, zoned); opaque materials are altered titanomagnetite.

Large plagioclase is $\mathrm{An}_{87}$ zoned to $\mathrm{An}_{79}$ and $\mathrm{An}_{67}$ on rim; groundmass plagioclase is $\mathrm{An}_{65}$; groundmass clinopyroxene $(0.2 \mathrm{~mm})$ is zoned Fs $13 \%$ $20 \%$.

\section{Sample 121-758A-55R-5, 31-35 cm, [HLD 3/101, 5/39], flow Unit 758A-F1}

Aphyric with doleritic (diabasic) texture, plagioclase laths $0.5-1 \mathrm{~mm}$, clinopyroxene moderately altered, smectite throughout groundmass, sulfides. Not plagioclase-phyric.

Sample 121-758A-55R-5, 82-86 cm, [HLD 3/101, 5/39], flow Unit 758A-FI

Plagioclase-phyric (to $3 \mathrm{~mm}$ ), doleritic groundmass, clots of smectite, sulfide $0.5 \mathrm{~mm}$.

Sample 121-758A-56R-1, 64-68 cm, [HLD 3/107, 130, 4/179-80, 5/41], near base of flow Unit 758 A-FI

Finer plagioclase-phyric and plagioclase-glomerophyric basalt (plagioclase phenocrysts to $1 \mathrm{~mm}$, plagioclase in groundmass to $0.5 \mathrm{~mm}$ ), with titanomagnetite and sulfides. (Finer than preceding flow Unit 758A-F1 samples.)

Megaplagioclase is zoned from $\mathrm{An}_{88}$ (core) to $\mathrm{An}_{44} \mathrm{Or}_{2}$ (rim); groundmass plagioclase is $\mathrm{An}_{67}$; groundmass clinopyroxene $(0.1-0.3 \mathrm{~mm})$ is $\mathrm{Fs} 9 \%$ and $\mathrm{Fs}$ $13 \%$. Sulfide is chalcopyrite with $1.2 \%-2.0 \% \mathrm{Ni}$ and $1.4 \%-2.2 \% \mathrm{Co}$.

\section{Sample 121 $7588 A-57 R-3,18-22 \mathrm{~cm}$, [HLD 3/101, 5/41], flow Unit 758A-F2}

A chill zone. Fine dark brownish gray plagioclase-clinopyroxene-phyric basalt of phenocrysts 0.25 to $1 \mathrm{~mm}$ in microcrystalline quench groundmass; black smectite veinlet. Sulfides in smectite clots.

\section{Sample 121-758A-58R-1, 86-90 cm, [HLD 3/101, 4/67-8, 5/41], flow Unit $758 A-F 2$}

Dark gray medium-grained basalt with fuzzy black areas of smectite alteration; sparsely plagioclase-phyric (to $2 \mathrm{~mm}$ ) with titanomagnetite, smectite replaces quench or glass; white zeolite in shrinkage cracks in smectite; sulfides clinopyroxene and pyrite $(0.22 \mathrm{~mm})$ are associated with smectite.

Fewer phenocrysts than, for example, flow Unit 758A-F1.

Plagioclase, $0.3 \mathrm{~mm}$, is zoned from $\mathrm{An}_{72}$ (core) to $\mathrm{An}_{50} \mathrm{Or}_{1}$ (rim), clinopyroxene $0.3 \mathrm{~mm}$ zoned Fs $10 \% \rightarrow$ Fs $14 \%$; titanomagnetite $0.08 \mathrm{~mm}$.

Sample 121-758A-58R-3, 62-66 cm, [HLD 3/101, 5/43], flow Unit 758A-F2

Similar dark gray medium-grained basalt with fuzzy areas of black smectite alteration.

Sparsely plagioclase-phyric (to $3 \mathrm{~mm}$ ) with smectite blebs in groundmass and much sulfides in smectite. Note 1-mm grain of chalcopyrite.

\section{Sample 121-758A-58R-5, 40-44 cm, [HLD 3/107, 111-112, 5/41], flow Unit $758 A-F 2$}

Intersertal, aphyric, doleritic, laths to $1 \mathrm{~mm}$, dark smectite throughout groundmass, no sulfides. Clinopyroxene is Fe rich, as though from evolved melt.

Large plagioclase is zoned from $\mathrm{An}_{50}$ (core) to $\mathrm{An}_{52} \mathrm{Or}_{1}$ (rim); clinopyroxene $(0.15 \mathrm{~mm})$ is Fs $21 \%-23 \%$; titanomagnetite.

Sample 121-758A-58R-6, 21-25 cm, [HLD 3/107, 132, 5/43], flow Unit $758 A-F 2$

Intersertal, aphyric, doleritic plagioclase and clinopyroxene, some as rosettes, $1 \mathrm{~mm}$, dark smectite throughout and as clots. Ophitic titanomagnetite and ilmenite. No sulfides.
Barrel sheet description: black smectite vertical anastomosing veinlets and some fibrous calcite.

Sample 121-758A-58R-7, 67-71 cm, [HLD 3/101, 5/43], flow Unit 758A-F2

Dark, medium-grained basalt with fuzzy areas of black smectite and some clinopyroxene.

Sparsely plagioclase-phyric ( $2 \mathrm{~mm}$, zoned) with subophitic clinopyroxene microphenocrysts $(1 \mathrm{~mm})$, smectite blebs in groundmass with sulfides.

Coarser and porphyritic variant of Sample 121-758A-58R-6, 21-25 cm.

Barrel sheet description: black smectite veinlets.

Sample 121-758A-59R-2, 58-62 cm, [HLD 3/107, 137-138, 4/176-179, 5/43], flow Unit 758 A-F 2

Intersertal, aphyric, doleritic, titanomagnetite, with smectite throughout. Sulfides: clinopyroxene and clinopyroxene-millerite mixture, in smectite and associated with titanomagnetite.

Plagioclase to $1 \mathrm{~mm}$ is zoned from $\mathrm{An}_{67}$ (core) to $\mathrm{An}_{45} \mathrm{Or}_{1}$ (rim); clinopyroxene $0.12 \mathrm{~mm}$ is Fs $9.6 \% \rightarrow$ Fs $11.7 \%$; brown translucent smectite associated with sulfides has $5 \% \mathrm{Na}_{2} \mathrm{O}$ and $2 \% \mathrm{~K}_{2} \mathrm{O}$ (p. 3/138).

Sulfides are chalcopyrite-millerite mixture with variable $\mathrm{Cu}, \mathrm{Co}$, and $\mathrm{Ni}$ and much chalcopyrite with $>2 \% \mathrm{Co}$ and $>2 \% \mathrm{Ni}$; grains to $0.025 \mathrm{~mm}$. Aphyric.

\section{Sample 121-758A-59R-4, 108-112 cm, [HLD 3/101, 5/45], flow Unit $758 \mathrm{~A}-\mathrm{F} 2$}

Medium-grained basalt with fuzzy black smectite blebs.

Very sparsely plagioclase-phyric $(2 \mathrm{~mm})$, smectite throughout and in blebs. Sulfides.

\section{Sample 121-758A-59R-6, 61-65 cm, [HLD 3/101, 5/47], flow Unit 758A-F2}

Similar but fuzzy areas of smectite alteration are smaller and more evenly distributed.

Aphyric, doleritic (some rosettes), smectite in groundmass and blebs, sulfides.

Change of texture; smectite disseminated, laths are finer.

Sample 121-758A-59R-7, 110-114 cm, [HLD 3/102, 5/47], flow Unit $758 A-F 2$

Sparsely microglomerophyric (plagioclase, clinopyroxene) in finer groundmass ( $0.5-\mathrm{mm}$ laths) with smectite and sulfides. Smectite does not form fuzzy blebs as in preceding samples, but is disseminated.

Sample 121-758A-60R-1, 41-45 cm, [HLD 3/102, 4/53-56, 5/47], bottom of flow Unit $758 A-F 2$

Medium-grained basalt, no vesicles; fine sulfides, blebs of zeolite with corona of black smectite.

Sparsely plagioclase-clinopyroxene microglomerophyric in finer groundmass of subophitic plagioclase laths and stubby clinopyroxene and fine fibrous smectite, some clinopyroxene and titanomagnetite.

Plagioclases, $0.1 \mathrm{~mm}$, are zoned (e.g., $\mathrm{An}_{71}$ to $\mathrm{An}_{67}$ and $\mathrm{An}_{69}$ to $\mathrm{An} 73$ to $\mathrm{An}_{63}$ ); clinopyroxene $0.13 \mathrm{~mm}$ is $\mathrm{Fs} 10 \%$ to $\mathrm{Fs} 14 \%$, and clinopyroxene 0.02 $\mathrm{mm}$ is Fs $15 \%$.

Sample 121-758A-60R-1, 122-126 cm, [HLD 3/102, 5/49], top of flow Unit $758 A-F 3$

Dark gray, medium-grained, sparsely glomerophyric (plagioclase, clinopyroxene), holocrystalline basalt; groundmass laths $0.5 \mathrm{~mm}$, smectite finely disseminated and in veinlet. No sulfides.

Sample 121-758A-60R-2, 86-90 cm, [HLD 3/102, 5/49], flow Unit 758A-F3

Medium-grained basalt, doleritic texture, fuzzy black areas of smectite, similar to but coarser than the preceding sample (laths $0.5-0.75 \mathrm{~mm}$ ), no sulfides.

Sample 121-758A-60R-3, 18-22 cm, [HLD 3/102, 5/49], flow Unit 758A-F3

Dark gray medium-grained basalt with disseminated sulfides. Similar to the preceding sample, sparsely glomerophyric (to $2 \mathrm{~mm}$ ), doleritic, with disseminated smectite. Zone of more intense alteration to smectite has coarse sulfides. 
Sample 121-758A-60R-5, 53-57 cm, [HLD 3/102, 5/49], flow Unit 758A-F3

Dark gray medium-grained basalt, areas of black smectite, aphyric, doleritic (1-mm laths); smectite in blebs.

\section{Sample 121-758A-60R-5, 130-134 cm, [HLD 3/102, 4/57-59, 5/51], flow Unit $758 A-F 3$}

Dark gray medium-grained basalt with disseminated sulfides. Plagioclasephyric (to $2 \mathrm{~mm}$ ) with groundmass of equant ophitic clinopyroxene to $1 \mathrm{~mm}$ and plagioclase laths to $0.5 \mathrm{~mm}$, disseminated smectite; titanomagnetite. Cuspate zeolite occupies shrinkage areas in smectite.

Plagioclase phenocryst $(1 \mathrm{~mm})$ in glomerocryst is $\mathrm{An}_{87}$. Plagioclase laths $(0.2 \mathrm{~mm})$ ophitic in clinopyroxene are $\mathrm{An}_{75}$ and $\mathrm{An}_{62}$. Clinopyroxene $(0.3 \mathrm{~mm})$ is Fs $10 \% \rightarrow$ Fs $15 \%$. Fibrous groundmass is "chlorite."

\section{Sample 121-758A-61R-2, 32-36 cm, [HLD 3/102, 5/51], flow Unit 758A-F3}

Aphyric. Dark gray medium-grained basalt with black blebs of smectite to $1.5 \mathrm{~mm}$.

Doleritic texture, plagioclase laths to $0.75 \mathrm{~mm}$ and a few microphenocrysts, disseminated smectite with zeolite centrally.

Sample 121-758A-61R-5, 22-26 cm, [HLD 3/102, 4/60, 5/51], flow Unit $758 A-F 3$

Dark gray medium-grained basalt, aphyric, $30 \%-40 \%$ is smectite blebs; sulfides; titanomagnetite.

Finely fibrous smectite ( $\mathrm{Si}, \mathrm{Mg}, \mathrm{Fe}$, and $\mathrm{Al}$ peaks, chlorite?) is intersertal, zeolite in shrinkage cracks.

Plagioclase $0.2 \mathrm{~mm}, \mathrm{An}_{64} \rightarrow \mathrm{An}_{61}$; clinopyroxene $0.2 \mathrm{~mm}$, Fs $15 \% \rightarrow \mathrm{Fs}$ $32 \%$; chlorite; titanomagnetite.

\section{Sample 121-758A-61R-7, 6-10 cm, [HLD 3/102, 5/53], flow Unit 758A-F3}

Very sparsely plagioclase-phyric, doleritic, laths to $0.75 \mathrm{~mm}$, disseminated smectite, rare sulfides.

Sample 121-758A-62R-1, 130-134 cm, [HLD 3/103, 5/53], start of flow Unit $758 A-F 4$, a massive deep-sea flow or sill

Gray, medium-grained basalt, slightly coarser than Sample 121-758A$61 \mathrm{R}-7,6-10 \mathrm{~cm}$, (laths to $1 \mathrm{~mm}$ ) sparsely plagioclase- (and plagioclaseclinopyroxene-) phyric, smectite in large (to $3 \mathrm{~mm}$ ) irregular bodies, fine sulfides. Veinlet of calcite? with smectite reaction on veinlet walls.

\section{Sample 121-758A-62R-3, 80-84 cm, [HLD 3/103, 5/53], flow Unit 758A-F5,} a thin flow or sill

A chill zone. Very dark brownish gray, plagioclase- (clinopyroxene-) phyric "chloritic" fine basalt with "chlorite" (smectite) veinlets.

Plagioclase-clinopyroxene glomerocrysts to $2 \mathrm{~mm}$ in very fine-grained groundmass $(0.3 \mathrm{~mm})$ much altered to smectite.

Sample 121-758A-62R-4, 13-17 cm, [HLD 3/103, 5/53], flow Unit 758A-F6, a thin flow or sill

Dark gray medium-grained basalt with black smectite blebs, aphyric. holocrystalline.

Sample 121-758A-63R-1,11-15 cm, [HLD 3/103, 5/55], top of flow Unit

$758 A-F 7$, a massive flow or sill with internal chilled contacts

Dark brownish gray medium-grained basalt with unusual texture, small angular blebs and veinlets of black smectite, disseminated fine sulfides.

Quench texture, laths to $0.5 \mathrm{~mm}$, very strong development of smectite and much sulfides.

Sample 121-758A-63R-3, 109-113 cm, [HLD 3/1-3, 4/62-66, 5/55], internal chilled contact in flow Unit $758 \mathrm{~A}-\mathrm{F} 7$

A chill zone. Thin section shows contact between quench-textured and medium-grained ( 0.75 - $\mathrm{mm}$ laths) intersertal to holocrystalline basalt. Sulfide in smectite in quench basalt.

Medium-grained (earlier) basalt has clinopyroxene $0.25 \mathrm{~mm}$ Fs $10 \% \rightarrow$ Fs $22 \%$ and plagioclase $0.3 \mathrm{~mm} \mathrm{An}_{69 \rightarrow 63}$, also titanomagnetite and ilmenite to $0.015 \mathrm{~mm}$. Quenched (younger) basalt has clinopyroxene farther from contact only, $0.25 \mathrm{~mm}$, Fs $12 \% \rightarrow$ Fs $27 \%$; microplagioclase near contact is $0.05 \mathrm{~mm}$ and $\mathrm{An}_{50}$ and $\mathrm{An}_{49}$; plagioclase farther from contact is $0.2 \mathrm{~mm}$ and zoned from $\mathrm{An}_{71}$ (core) to $\mathrm{An}_{56}$ (rim); also titanomagnetite $0.06 \mathrm{~mm}$; also chalcopyrite $0.006 \mathrm{~mm}$, rare. Veinlet not identified, zeolite?

\section{Sample 121-758A-63R-3,114-118 cm, [HLD 3/103, 5/55], flow Unit $758 \mathrm{~A}-\mathrm{F} 7$}

Similar dark gray medium-grained basalt with fine sulfides.

Sparsely phyric holocrystalline doleritic basalt with smectite throughout. Sulfides to $1 \mathrm{~mm}$ in smectite.

\section{Sample 121-758A-63R-7, 107-111 cm, [HLD 3/103, 5/57], flow Unit $758 A-F 7$}

Similar dark gray medium-grained basalt, but black smectite blebs or clots are more prominent, $20 \%$, and slightly coarser grained than in Sample 121758A-63R-3, 114-118 cm, (0.75-1.0 mm); aphyric; sulfides.

\section{Sample 121-758A-64R-2,121-125 cm, [HLD 3/103, 5/57], near bottom of flow Unit $758 \mathrm{~A}-\mathrm{F} 7$}

Dark gray, finer grained $(0.3 \mathrm{~mm})$ basalt, sparsely plagioclase-phyric, with smectite clots to $1 \mathrm{~mm}$ and sulfides throughout.

\section{Sample 121-758A-64R-3, 63-67 cm, [HLD 3/103, 5/57], thin flow near} bottom of flow Unit $758 \mathrm{~A}-\mathrm{F} 8$

A chill zone. Quench-texture basalt, laths $0.3 \mathrm{~mm}$; note area of intense smectite alteration with white zeolite at center in cracks; smectite (montmorillonite) confirmed by XRD; also much smectite throughout. Sulfides.

\section{Sample 121-758A-64R-4, 54-58 cm, [HLD 3/104, 4/81, 5/59], thin flow near base of flow Unit $758 \mathrm{~A}-\mathrm{F} 9$}

Dark gray medium-grained basalt with doleritic texture and scattered clots of black smectite.

Sparsely plagioclase- (and clinopyroxene-) phyric, holocrystalline (groundmass laths $0.5 \mathrm{~mm}$ ) with much smectite; relict microcrystalline texture in some smectite.

Reaction rim of plagioclase phenocryst ( $1 \mathrm{~mm}$, altered) is $\mathrm{An}_{67}$. groundmass plagioclase rim is $\mathrm{An}_{48} \mathrm{Or}_{1}$; clinopyroxene $0.1 \mathrm{~mm}$ is $\mathrm{Fs} 10 \%$ with rim Fs $10 \%$.

\section{Sample 121-758A-65R-1,51 cm, [HLD 3/104,5/59], top of flow Unit} $758 A-F 10$

A chill zone. Dark gray, grain size $<0.3 \mathrm{~mm}$, sparsely amygdaloidal, smectite in groundmass, amygdales, veinlets, and blebs. Blebs of smectite contain some white zeolite and coarse sulfides, including clinopyroxene, $2 \mathrm{~mm}$.

Sample 121-758A-65R-4, 62-66 cm, [HLD 3/104, 5/59], flow Unit 758A-F10

Medium-grained altered basalt, coarser $(0.75 \mathrm{~mm})$ than Sample 121-758A$65 \mathrm{R}-1,51 \mathrm{~cm}$, sparsely plagioclase-phyric; smectite and calcite alteration in groundmass (calcite in cores of smectite blebs). Sulfide in smectite-calcite veinlet and disseminated in clinopyroxene and probably pyroxene.

Sample 121-758A-65R-6, 30-34 cm, [HLD 3/104, 5/61], near base of flow Unit 758 A-F10

Medium-grained holocrystalline basalt with dark smectite dispersed throughout, replacing mesostasis. Plagioclase laths to 0.6 and $1.0 \mathrm{~mm}$, equant clinopyroxene to $0.3 \mathrm{~mm}$.

Sample 121-758A-66R-1, 55-59 cm, [HLD 3/104, 5/61], near top of flow Unit $758 A-F 11$, could be the same as flow Unit $758 A-F 10$

Similar to Sample 121-758A-65R-4, 62-66 cm, but finer (laths to $0.5 \mathrm{~mm}$ ), dark gray basalt, pervasive alteration, sparsely plagioclase-phyric, clots of smectite throughout.

Sample 121-758A-66R-4, 29-33 cm, [HLD 3/104, 5/61], flow Unit 758A-F1]

Coarser aphyric holocrystalline basalt with blebs of smectite. 
Sample 121-758A-66R-5, 28-32 cm, [HLD 3/104, 5/61], near base of flow Unit 758A-F11 and possibly flow Unit 758A-F10

A chill zone. Very fine grained, much smectite, much sulfides including clinopyroxene. Most sulfides are in most highly altered (smectite) area.

Sample 121-758A-66R-6, 42-46 cm, [HLD 3/104, 5/63], flow Unit 758A-F12

Sparsely plagioclase-phyric holocrystalline basalt with disseminated smectite; phenocrysts $1.5 \mathrm{~mm}$, groundmass laths $0.7 \mathrm{~mm}$.

Sample 121-758A-67R-2, 92-96 cm, [HLD 3/104, 5/63], flow Unit 758A-F13

Similar to the preceding sample but aphyric, plagioclase laths $0.7 \mathrm{~mm}$, clinopyroxene $0.5 \mathrm{~mm}$, disseminated smectite, sulfides.

Sample 121-758A-67R-4, 31-35 cm, [HLD 3/104, 5/65], near base of flow Unit $758 A-F 14$

Similar, aphyric, fine-grained (laths $0.5 \mathrm{~mm}$ ), smectite clots throughout.

Sample 121-758A-67R-5, 86-90 cm, [HLD 3/107, 123-4, 5/65], flow Unit $758 A-F 15$

Similar but glomerophyric (plagioclase-clinopyroxene), fine groundmass ( $0.5 \mathrm{~mm}$ laths), titanomagnetite and rare ilmenite. Groundmass much altered to dark smectite.

Megaplagioclase in glomerocryst is $\mathrm{An}_{83}$ with rim $\mathrm{An}_{87}$; rim of groundmass plagioclase $(0.6 \mathrm{~mm})$ is $\mathrm{An}_{60} \mathrm{Or}_{1}$; clinopyroxene in glomerocryst is $\mathrm{Fs} 9 \%$; clinopyroxene in groundmass $(0.22 \mathrm{~mm})$ is $\mathrm{Fs} 11 \% \rightarrow \mathrm{Fs} 15 \%$.

\section{Sample 121-758A-68R-2, 8-12 cm, [HLD 3/104, 5/65], flow Unit 758A-F16}

A chill zone. Plagioclase laths and clinopyroxene to $0.3 \mathrm{~mm}$ in smectite (smectite confirmed by XRD, J. Kamprad, BMR, 1989). Forty percent is irregular blebs of smectite up to $7 \mathrm{~mm}$ across. Much sulfides.

\section{Sample 121-758A-68R-3, 122-126 cm, [HLD 3/104, 5/67], flow Unit $758 A-F 17$}

Plagioclase- (clinopyroxene-) phyric (phenocrysts to $3 \mathrm{~mm}$ ) in doleritic groundmass (laths to $0.5 \mathrm{~mm}$ ) with much smectite in groundmass and as amygdules.

\section{Sample 121-758A-69R-3, 53-57 cm, [HLD 3/105, 4/89-92, 5/67 and 100],} flow Unit $758 A-F 17$

Dark gray, pervasively altered, medium-grained basalt with clots of smectite, some of which have fibrous calcite at the center of clot.

Plagioclase and clinopyroxene phenocrysts (both to $3 \mathrm{~mm}$ ) in doleritic groundmass (laths to $0.75 \mathrm{~mm}$ ); groundmass is $15 \%-20 \%$ smectite. Clinopyroxene phenocrysts are zoned.

Megaplagioclase $\left(1.8 \mathrm{~mm}\right.$ ) is zoned from $\mathrm{An}_{85}$ (core) to $\mathrm{An}_{58}$ (rim); clinopyroxene phenocrysts are zoned in $\mathrm{Ti}, \mathrm{Al}$, and $\mathrm{Cr}$ with $\mathrm{Fs} 11.6 \%$ to $\mathrm{Fs}$ $27.6 \%$ and $\mathrm{Fs} 9 \%$ to $\mathrm{Fs} 25.9 \%$; pyrrhotite $(0.010 \mathrm{~mm})$, also titanomagnetite $(0.06 \mathrm{~mm})$.

\section{Sample 121-758A-69R-5, 106-110 cm, [HLD 3/105, 5/67], near base of} flow Unit $758 A-F 17$

A chill zone. Plagioclase and clinopyroxene phenocrysts, fine-grained groundmass (laths to $0.3 \mathrm{~mm}$ ) with clots of smectite $(2 \mathrm{~mm})$, some with zeolite or calcite. Sulfides.

\section{Sample 121-758A-70R-1, 71-75 cm, [HLD 3/105, 4/188, 5/69], flow Unit $758 A-F 18$}

Brownish dark gray, sparsely clinopyroxene-phyric (to $1 \mathrm{~mm}$ ), fine doleritic groundmass (laths to $0.5 \mathrm{~mm}$ ) with smectite throughout, some disseminated sulfides.

Plagioclase $0.2 \mathrm{~mm} \mathrm{An} 66 \rightarrow 65$; clinopyroxene phenocryst Fs $8.5 \% \rightarrow$ Fs $15 \%$; groundmass clinopyroxene $0.8 \mathrm{~mm}$ Fs $12 \% \rightarrow$ Fs $15 \%$.

Sample 121-758A-70R-2, 129-133 cm, [HLD 3/105, 5/69], flow Unit 758 A-F19, a thin pillow lava flow

A chill zone. Very fine-grained doleritic $(0.25-\mathrm{mm}$ laths $)$ with parallel linear concentrations of smectite, zeolite in shrinkage cracks (photographed). Sulfides.
Sample 121-758A-7IR-1, 127-131 cm, [HLD 3/107, 3/135-6, 5/69], flow

Unit 758 A-F 20

Sparsely plagioclase-clinopyroxene-microglomerophyric holocrystalline $(0.5 \mathrm{~mm})$ basalt with smectite throughout.

Plagioclase phenocryst is zoned from $\mathrm{An}_{74}$ (core) to $\mathrm{An}_{65}$ (rim), plagioclase lath rim is $\mathrm{An}_{62}$, and plagioclase rim on glomerocryst, $0.04 \mathrm{~mm}$ across, is $\mathrm{An}_{60}$. Clinopyroxene in glomerocryst is Fs $8 \%$ and in groundmass is Fs $17 \%$. Titanomagnetite, sulfides, clinopyroxene $2-4 \mu \mathrm{m}$.

Sample 121-758A-71R-3, 64-68 cm, [HLD 3/105, 5/71], flow Unit $758 \mathrm{~A}-\mathrm{F} 22$, a thin flow or part of pillow lava sequence

Dark gray medium-grained basalt, pervasively altered; sparsely plagioclase-phyric $(2 \mathrm{~mm})$, with fine doleritic groundmass $(0.2-0.5-\mathrm{mm}$ laths); disseminated smectite, sulfides.

Sample 121-758A-71R-3, 140-144 cm, [HLD 3/105, 5/71], flow Unit $758 A-F 23$, part of pillow lava sequence?

Similar to the preceding Sample 121-758A-71R-3, 64-68 cm. Sparsely plagioclase-phyric $(2 \mathrm{~mm})$, fine doleritic groundmass $(0.2-0.5 \mathrm{~mm})$, smectite and calcite alteration, sulfides to $2 \mathrm{~mm}$.

Sample 121-758A-72R-3, 81-85 cm, [HLD 3/105, 4/80, 125, 5/73], flow Unit 758 A-F25

Similar to the preceding two samples. Sparsely plagioclase-clinopyroxeneglomerophyric (1-2 mm), fine doleritic groundmass $(0.25 \mathrm{~mm})$ with disseminated smectite; also linear blebs of smectite $2 \mathrm{~mm}$ across (probably the pipe vesicles noted in the barrel sheet description); sulfides in hand specimen.

\section{Sample 121-758A-72R-3, 95-99 cm, [HLD 3/105, 5/71], at bottom of flow} Unit 758 A- $F 24$

Similar to the above three samples. Sparsely clinopyroxene and plagioclase phyric $(1 \mathrm{~mm})$, fine doleritic groundmass $(0.25 \mathrm{~mm})$; disseminated smectite; no sulfides.

Plagioclase lath, $0.2 \mathrm{~mm}$, is zoned from $\mathrm{An}_{74}$ (core) to $\mathrm{An}_{49}$ (rim); clinopyroxene $0.6 \mathrm{~mm}$ is Fs $8 \% \rightarrow \mathrm{Fs} 13 \%$; clinopyroxene $0.1 \mathrm{~mm}$ is Fs $11 \%$ $\rightarrow$ Fs $20 \%$.

\section{Sample 121-758A-72R-4, 27-31 cm, [HLD 5/73], flow Unit 758A-F25}

Sparsely plagioclase-phyric (to $3 \mathrm{~mm}$ ), sparsely amygdaloidal basalt; groundmass is $0.2-\mathrm{mm}$ plagioclase and $0.05-\mathrm{mm}$ clinopyroxene; $15 \%-20 \%$ smectite after mesostasis.

Sample 121-758A-72R-6, 18-22 cm, [HLD 3/105, 5/73], flow Unit $758 \mathrm{~A}-\mathrm{F} 26$, a thin flow interbedded in pillow sequence

Sparsely plagioclase-phyric; fine doleritic groundmass $(0.25 \mathrm{~mm})$, disseminated smectite (and zeolite); fine sulfides.

Samples 121-758A-71R-3, 64-68 cm, to 121-758A-72R-6, 18-22 cm, are very similar.

\section{Sample 121-758A-73R-1, 82-86 cm, [HLD 3/105, 5/75], flow Unit $758 \mathrm{~A}-\mathrm{F} 27$, thin flow}

Similar to the preceding group but coarser grained (to $0.8 \mathrm{~mm}$ ); aphyric; much smectite as clots, $1-2 \mathrm{~mm}$, throughout.

Sample 121-758A-73R-2, 10-14 cm, [HLD 3/105, 5/75], flow Unit 758A-F27

Similar. Plagioclase-clinopyroxene-phyric (1-2 mm) with mediumgrained doleritic groundmass $(0.8 \mathrm{~mm})$; smectite throughout but fewer visible clots than in Sample 121-758A-73R-1, 82-86 cm; sulfides.

Sample 121-758A-73R-3, 50-54 cm, [HLD 3/107, 120-1, 4/115-7, 5/75], pillow lavas at base of flow Unit $758 \mathrm{~A}-\mathrm{F} 28$

A chill zone. Clinopyroxene-plagioclase-glomerophyric quench-texture basalt. Plagioclase reacts with groundmass; much smectite alteration; note calcite rhomb in smectite in amygdule (photographed); also sulfides.

Plagioclase phenocryst $0.25 \mathrm{~mm}$ is $\mathrm{An}_{83 \rightarrow 77}$ with reaction rim $\mathrm{An}_{72}$; another phenocryst $0.8 \mathrm{~mm}$ is $\mathrm{An}_{77 \rightarrow 86}$ and $\mathrm{An}_{77 \rightarrow 77}$, and reaction rim (0.01 $\mathrm{mm})$ is $\mathrm{An}_{86}$; plagioclase microphenocrysts $0.1 \mathrm{~mm}$ are $\mathrm{An}_{53}$ and $\mathrm{An}_{71}$; groundmass plagioclase $0.05 \mathrm{~mm}$ is $\mathrm{An}_{68}$. Clinopyroxene phenocrysts $0.2 \mathrm{~mm}$ 
are Fs $9 \% \rightarrow$ Fs $13 \%$; groundmass clinopyroxene $0.05 \mathrm{~mm}$ is Fs $11 \%$. Sulfides are pyrite and a $0.15-\mathrm{mm}$ grain of chalcopyrite with high $\mathrm{Co}$ and $\mathrm{Ni}$ or a chalcopyrite-millerite-linnaeite mix (cf. Sample 121-758A-59R-2, 58-62 cm, also Samples 121-758A-56R-1, 64-68 cm, and 121-758A-73R-4, 105-109 $\mathrm{cm})$.

Sample 121-758A-73R-3, 132-136 cm, [HLD 3/105, 5/75], flow Unit $758 A-F 29$

Finer. Amygdaloidal aphyric fine-grained basalt (laths $0.2 \mathrm{~mm}$ ) with small blebs smectite; sulfides.
Sample 121-758A-73R-4, 105-109 cm, [HLD 3/105, 4/180-1, 5/77], flow Unit $758 A-F 29$

Sparsely plagioclase- (clinopyroxene-) phyric basalt, groundmass laths 0.5 $\mathrm{mm}$, much smectite alteration both as disseminated clots and as alteration "veinlet" along microfracture; smectite veinlet is $3-4 \mathrm{~mm}$ across and has pyrite $1 \mathrm{~mm}$ centrally.

Sulfide large grains are pyrite; small grains, $6-8 \mu \mathrm{m}$, are chalcopyrite with $2.9 \%-3.4 \%$ Co and $2.2 \%-3.1 \% \mathrm{Ni}$. 
APPENDIX B

Selected Mineral Analyses

\section{Clinopyroxene}

\begin{tabular}{|c|c|c|c|c|c|c|c|c|c|}
\hline & 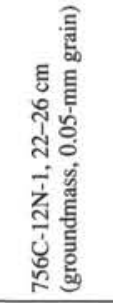 & 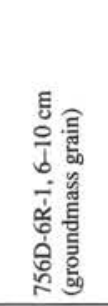 & 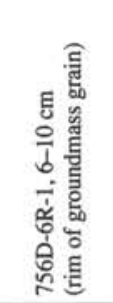 & 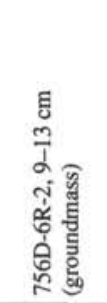 & 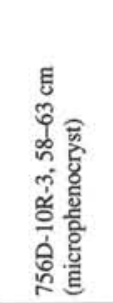 & 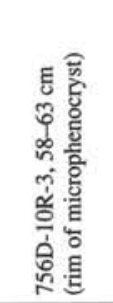 & 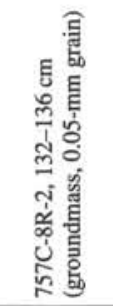 & 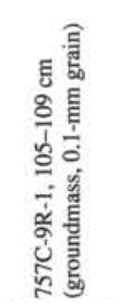 & 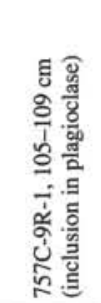 \\
\hline $\mathrm{SiO}_{2}$ & 51.6 & 51.9 & 50.7 & 50.2 & 50.5 & 51.4 & 53 & 52 & 50.2 \\
\hline $\mathrm{TiO}_{2}$ & 0.98 & 0.76 & 0.85 & 1.03 & 1.05 & 0.99 & 0.51 & 0.85 & 1.76 \\
\hline $\mathrm{Al}_{2} \mathrm{O}_{3}$ & 2.52 & 1.99 & 1.15 & 4.11 & 4.03 & 1.88 & 1.55 & 1.99 & 3.92 \\
\hline $\mathrm{Cr}_{2} \mathrm{O}_{3}$ & 0.31 & 0.17 & - & 0.88 & 0.82 & - & 0.04 & - & 0.05 \\
\hline $\mathrm{FeO}$ & 8.46 & 10.6 & 18.4 & 7.54 & 7.83 & 10.6 & 8.4 & 12.2 & 17.5 \\
\hline $\mathrm{MnO}$ & 0.23 & - & 0.34 & - & - & - & 0.24 & 0.31 & 0.31 \\
\hline $\mathrm{MgO}$ & 15.6 & 15.2 & 13 & 15.6 & 15.9 & 15.1 & 17.2 & 14.7 & 12.8 \\
\hline $\mathrm{CaO}$ & 19.4 & 19.2 & 15.4 & 19.9 & 20.2 & 19.4 & 18.2 & 18.4 & 11.3 \\
\hline $\mathrm{Na}_{2} \mathrm{O}$ & 0.26 & - & - & - & 0.17 & 0.15 & 0.20 & 0.23 & 0.23 \\
\hline Total & 99.47 & 99.24 & 99.84 & 99.31 & 100.4 & 99.4 & 99.39 & 100.7 & 98.3 \\
\hline Cations per 60 & 4.001 & 3.996 & 4.003 & 3.999 & 4.015 & 4.006 & 3.996 & 4.005 & 3.949 \\
\hline $\mathrm{Mg}: \mathrm{Fe}: \mathrm{Ca}$ & $46: 14: 40$ & $43: 17: 40$ & $38: 30: 32$ & $45: 13: 42$ & $46: 13: 41$ & $43: 17: 40$ & $49: 14: 37$ & $42: 20: 38$ & $42: 32: 26$ \\
\hline $\mathrm{NiO}$ & 0.07 & & & & & & 0.06 & 0.06 & \\
\hline $\mathrm{K}_{2} \mathrm{O}$ & & & & & & & & 0.25 & \\
\hline
\end{tabular}

Plagioclase and K-Feldspar

\begin{tabular}{|c|c|c|c|c|c|c|c|c|c|c|c|c|c|c|}
\hline & 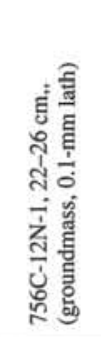 & 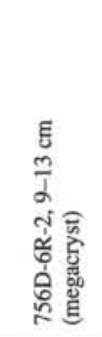 & 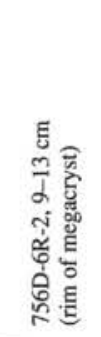 & 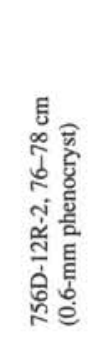 & 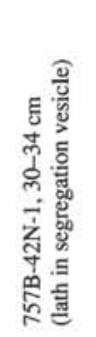 & 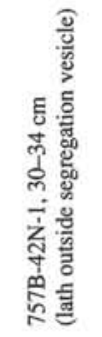 & 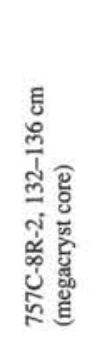 & 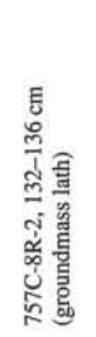 & 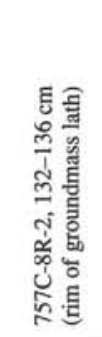 & 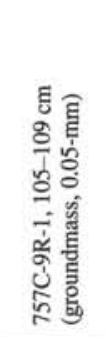 & 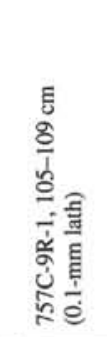 & 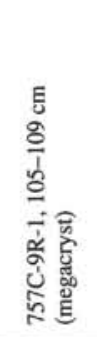 & 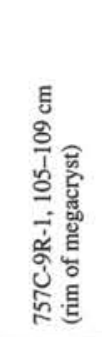 & 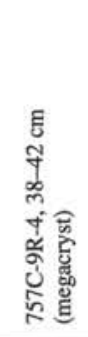 \\
\hline $\mathrm{SiO}_{2}$ & 53.4 & 47 & 57.7 & 51.2 & 57.5 & 54.4 & 47.1 & 50.3 & 55.0 & 54.5 & 59.2 & 47.7 & 56.0 & 46.7 \\
\hline $\mathrm{TiO}_{2}$ & 0.1 & - & - & 0.1 & 0.11 & 0.12 & 0.02 & 0.05 & 0.09 & 0.09 & 0.06 & - & 0.11 & 0.02 \\
\hline $\mathrm{Al}_{2} \mathrm{O}_{3}$ & 28.6 & 33.1 & 26.1 & 29.8 & 25.7 & 27.2 & 33.4 & 31.1 & 27.3 & 28.8 & 25.6 & 33.4 & 27.5 & 33.1 \\
\hline $\mathrm{FeO}$ & 0.89 & 0.48 & 0.66 & 0.94 & 1.03 & 1.22 & 0.48 & 0.54 & 1.19 & 0,74 & 0.71 & 0.45 & 0.84 & 0.45 \\
\hline $\mathrm{MgO}$ & 0.09 & - & - & 0.12 & 0.07 & 0.17 & 0.19 & 0.27 & 0.66 & 0.13 & 0.06 & 0.21 & 0.13 & 0.18 \\
\hline $\mathrm{CaO}$ & 12.2 & 16.5 & 8.02 & 13.7 & 8.57 & 10.6 & 17.34 & 14.0 & 10.6 & 11.9 & 8.16 & 17.1 & 10.4 & 17.3 \\
\hline $\mathrm{Na} 2 \mathrm{O}$ & 3.01 & 1.96 & 6.98 & 3.49 & 5.69 & 4.78 & 1.48 & 2.85 & 4.91 & 4.57 & 6.24 & 1.69 & 5.25 & 1.55 \\
\hline $\mathrm{K}_{2} \mathrm{O}$ & 0.20 & - & 0.5 & 0.13 & 0.28 & 0.22 & 0.02 & 0.05 & 0.2 & 0.15 & 0.4 & 0.04 & 0.21 & 0.03 \\
\hline Total & 98.45 & 98.9 & 99.88 & 99.44 & 98.87 & 98.74 & 100.03 & 99.21 & 99.91 & 100.84 & 100.39 & 100.55 & 100.43 & 99.26 \\
\hline $\begin{array}{l}\text { Cations per } \\
32 \mathrm{O}\end{array}$ & 19.662 & 19.99 & 20.121 & 19.999 & 19.843 & 19.948 & 19.982 & 19.909 & 19.995 & 19.962 & 19.871 & 19.992 & 19.945 & 20.004 \\
\hline An:Ab:Or & $68: 31: 1$ & $83: 17: 0$ & $38: 59: 3$ & 68: 31: 1 & $\begin{array}{c}45: 54: \\
1.8\end{array}$ & $54: 44: 1$ & $\begin{array}{c}86.5: \\
13: 0.1\end{array}$ & $\begin{array}{c}73: 27: \\
0.3\end{array}$ & $54: 45: 1$ & $58: 41: 1$ & $41: 57: 2$ & $\begin{array}{c}85: 15: \\
0.2\end{array}$ & $52: 47: 1$ & $\begin{array}{c}86: 14: \\
0.2\end{array}$ \\
\hline
\end{tabular}




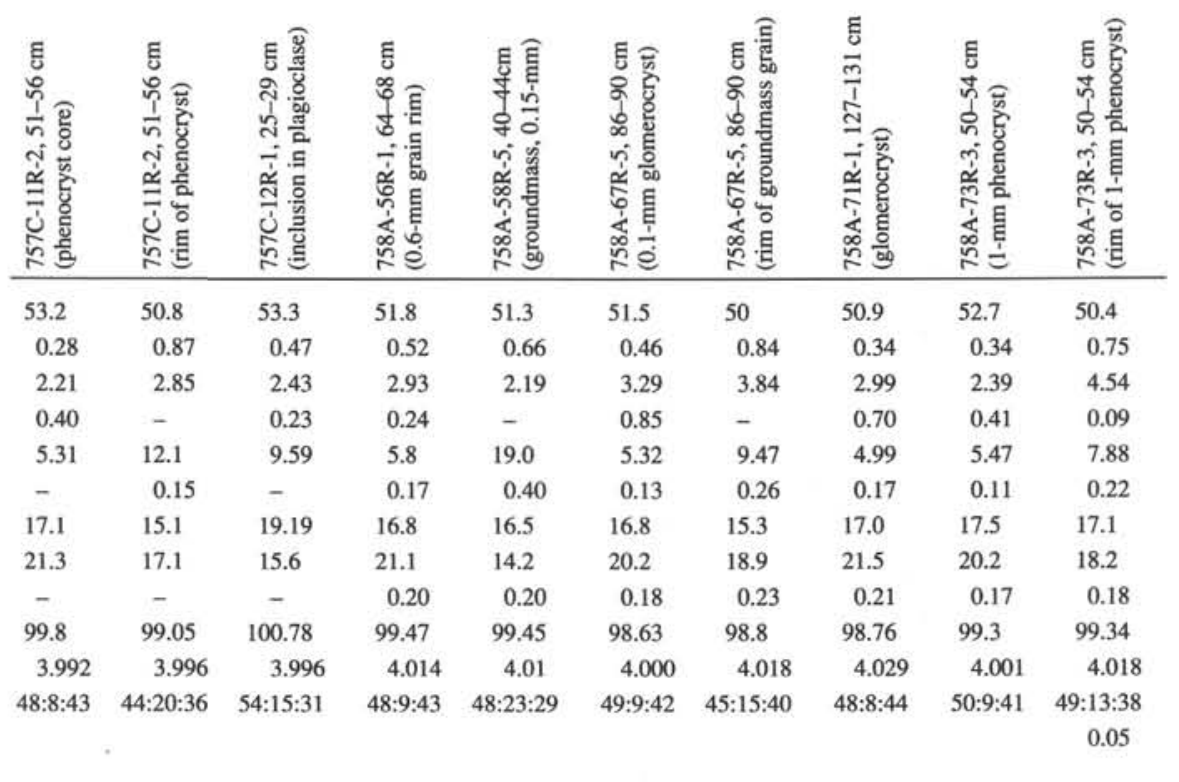

\begin{tabular}{|c|c|c|c|c|c|c|c|c|c|c|c|c|c|c|c|}
\hline \multicolumn{4}{|c|}{$\begin{array}{l}\text { 757C-9R-4, } 38-42 \mathrm{~cm} \\
\text { (traverse of } 0.05 \text {-mm-wide rim on } \\
\text { megacryst) }\end{array}$} & \multirow[t]{2}{*}{ 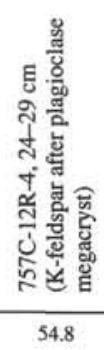 } & \multirow[t]{2}{*}{ 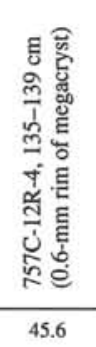 } & \multirow[t]{2}{*}{ 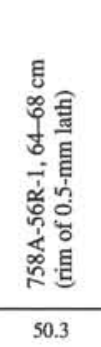 } & \multirow[t]{2}{*}{ 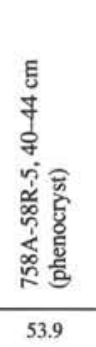 } & \multirow[t]{2}{*}{ 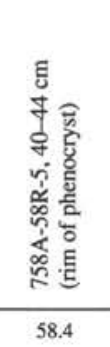 } & \multirow[t]{2}{*}{ 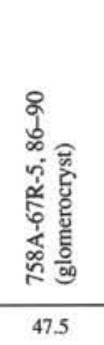 } & \multirow[t]{2}{*}{ 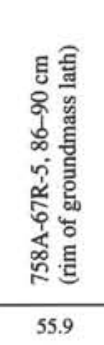 } & \multirow[t]{2}{*}{ 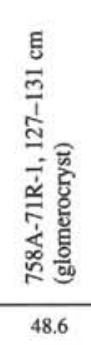 } & \multirow[t]{2}{*}{ 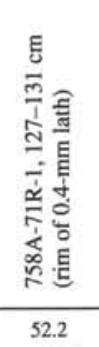 } & \multirow[t]{2}{*}{ 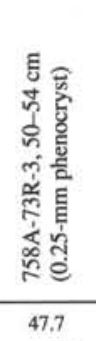 } & \multirow[t]{2}{*}{ 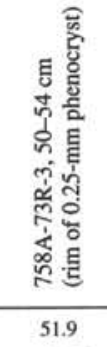 } & \multirow[t]{2}{*}{ 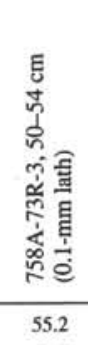 } \\
\hline 52.2 & 54.1 & 57.1 & 64.0 & & & & & & & & & & & & \\
\hline 0.04 & 0.08 & 0.09 & - & 0.09 & 0.02 & 0.06 & 0.08 & 0.05 & - & 0.07 & 0.03 & 0.07 & 0.02 & 0.05 & 0.13 \\
\hline 29.8 & 28.5 & 26.5 & 18.5 & 27.7 & 34.1 & 30.3 & 28.5 & 25.1 & 32.6 & 27.0 & 31.1 & 28.6 & 32.3 & 28.6 & 26.6 \\
\hline 0.6 & 0.78 & 0.92 & - & 0.83 & 0.55 & 0.78 & 0.87 & 0.73 & 0.45 & 1.18 & 0.61 & 1.02 & 0.51 & 1.14 & 1.37 \\
\hline 0.24 & 0.14 & 0.07 & - & 0.12 & 0.15 & 0.21 & 0.13 & 0.04 & 0.23 & 0.13 & 0.27 & 0.17 & 0.21 & 0.71 & 0.16 \\
\hline 13.3 & 11.4 & 9.19 & - & 10.6 & 18.1 & 14.2 & 12.0 & 8.86 & 16.6 & 10.5 & 15.3 & 12.5 & 16.5 & 1.3 & 10.4 \\
\hline 4.06 & 4.95 & 6.15 & - & 5.33 & 1.31 & 3.55 & 4.45 & 4.4 & 1.82 & 3.72 & 2.89 & 4.17 & 1.8 & 2.54 & 5.04 \\
\hline 0.09 & 0.13 & 0.23 & 16.35 & 0.2 & 0.01 & 0.03 & 0.08 & 0.14 & 0.02 & 0.13 & 0.02 & 0.07 & 0.06 & 0.29 & 0.18 \\
\hline 100.43 & 100.19 & 100.27 & 98.86 & 99.62 & 99.82 & 99.46 & 100 & 98.42 & 99.3 & 98.8 & 98.83 & 98.78 & 99.2 & 98.2 & 99.03 \\
\hline 20.058 & 20.037 & 20.018 & 19.945 & 20.038 & 20.076 & 20.091 & 19.956 & 19.479 & 19.984 & 19.593 & 20.09 & 20.021 & 19.977 & 19.767 & 19.948 \\
\hline $\begin{array}{c}\text { 64: } 35: \\
0.5\end{array}$ & $\begin{array}{c}56: 44: \\
0.7\end{array}$ & $45: 54: 1$ & Or $100 \%$ & $52: 47: 1$ & $\begin{array}{c}88: 12: \\
0.1\end{array}$ & $\begin{array}{c}\text { 69: } 31: \\
0.2\end{array}$ & $\begin{array}{c}59.5: \\
40: 0.5\end{array}$ & $52: 46: 1$ & $\begin{array}{c}83: 17: \\
0.1\end{array}$ & $60: 39: 1$ & $\begin{array}{c}74: 26: \\
0.1\end{array}$ & $\begin{array}{c}62: 37: \\
0.4\end{array}$ & $\begin{array}{c}\text { 83: 17: } \\
0.2\end{array}$ & $72: 26: 2$ & $53: 46: 1$ \\
\hline
\end{tabular}




\section{Titanomagnetite and Ilmenite}

\begin{tabular}{|c|c|c|c|c|c|c|c|c|c|c|c|c|}
\hline & 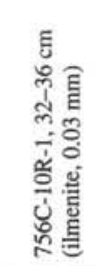 & 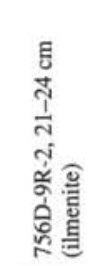 & 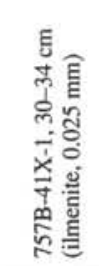 & 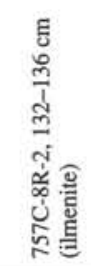 & 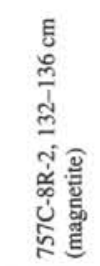 & 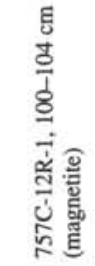 & 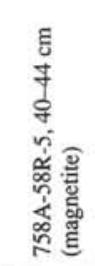 & 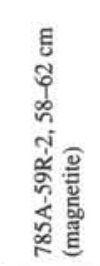 & 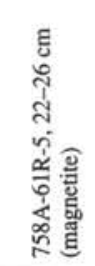 & 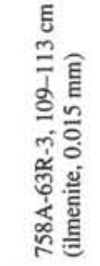 & 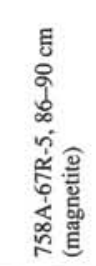 & 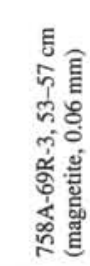 \\
\hline $\mathrm{SiO}_{2}$ & & 0.22 & 0.07 & 0.04 & 0.10 & 0.10 & 0.62 & 0.13 & 1.70 & 0.19 & 0.18 & 0.14 \\
\hline $\mathrm{TiO}_{2}$ & 50.34 & 48.0 & 47.25 & 48.6 & 30.0 & 24.5 & 22.8 & 23.7 & 21.8 & 47.4 & 22.2 & 22.5 \\
\hline $\mathrm{Al}_{2} \mathrm{O}_{3}$ & 0.07 & 0.13 & 0.07 & 0.03 & 1.50 & 0.92 & 2.04 & 1.25 & 1.46 & 0.09 & 2.05 & 1.57 \\
\hline $\mathrm{V}_{2} \mathrm{O}_{3}$ & 1.22 & - & 0.90 & 0.27 & 0.43 & 0.52 & 1.14 & 0.84 & 0.35 & 0.82 & 0.77 & 0.64 \\
\hline $\mathrm{Cr}_{2} \mathrm{O}_{3}$ & - & 0.25 & - & - & - & 0.04 & - & - & - & - & - & - \\
\hline $\mathrm{FeO}$ & 45.3 & 48.5 & 47.9 & 48.3 & 64.7 & 66.1 & 67.8 & 70.3 & 68.51 & 46.7 & 68.4 & 72.1 \\
\hline $\mathrm{MnO}$ & 0.63 & 0.35 & 0.89 & 0.61 & 0.5 & 4.81 & 2.03 & 1.78 & 1.56 & 0.58 & 3.56 & 1.45 \\
\hline $\mathrm{NiO}$ & - & - & - & - & - & - & - & & - & - & - & 0.04 \\
\hline $\mathrm{ZnO}$ & - & - & - & 0.15 & 0.23 & 0.15 & 0.12 & 0.10 & - & 0.16 & 0.17 & \\
\hline $\mathrm{MgO}$ & 2.00 & 1.86 & 0.39 & 0.76 & 0.44 & - & 0.68 & 0.47 & 1.12 & 0.63 & 0.08 & 0.39 \\
\hline $\mathrm{CaO}$ & 0.12 & 0.27 & 0.27 & 0.06 & 0.06 & 0.10 & 0.03 & 0.02 & 0.23 & 0.24 & 0.10 & 0.05 \\
\hline Total & 99.66 & 99.6 & 97.74 & 98.06 & 97.9 & 97.34 & 97.2 & 98.64 & 96.81 & 96.63 & 97.48 & 99 \\
\hline Cations per 40 & & & & & 3.087 & 3.221 & 3.224 & 3.241 & 3.235 & & 3.257 & 3.271 \\
\hline Cations per 60 & 4.061 & 4.131 & 4.106 & 4.096 & & & & & & 4.085 & & \\
\hline
\end{tabular}

Trapped Melt and Groundmass

\begin{tabular}{|c|c|c|c|c|c|c|}
\hline & \multicolumn{5}{|c|}{ Trapped melt: dark inclusions in plagioclase megacrysts } & \multirow[b]{2}{*}{$\begin{array}{l}757 \mathrm{~B}-41 \mathrm{X}- \\
30-34 \mathrm{~cm}^{\mathrm{a}}\end{array}$} \\
\hline & $\begin{array}{c}757 \mathrm{~B}-41 \mathrm{X}-1, \\
30-34 \mathrm{~cm}\end{array}$ & $\begin{array}{l}757 \mathrm{C}-8 \mathrm{R}-2, \\
132-136 \mathrm{~cm}\end{array}$ & $\begin{array}{l}757 \mathrm{C}-9 \mathrm{R}-1, \\
105-109 \mathrm{~cm}\end{array}$ & $\begin{array}{l}757 \mathrm{C}-9 \mathrm{R}-1 \\
105-109 \mathrm{~cm}\end{array}$ & $\begin{array}{c}757 \mathrm{C}-12 \mathrm{R}-2 \\
0-5 \mathrm{~cm}\end{array}$ & \\
\hline $\mathrm{SiO}_{2}$ & 44.1 & 42.3 & 45.4 & 45.5 & 45.6 & 46.7 \\
\hline $\mathrm{TiO}_{2}$ & - & 2.8 & 2.21 & 2.48 & 1.08 & 1.15 \\
\hline $\mathrm{Al}_{2} \mathrm{O}_{3}$ & 7.94 & 9.57 & 6.50 & 7.00 & 7.12 & 18.4 \\
\hline $\mathrm{Cr}_{2} \mathrm{O}_{3}$ & - & 0.03 & - & 0.05 & 0.06 & - \\
\hline $\mathrm{FeO}$ & 17.6 & 14.7 & 14.5 & 14.6 & 15.0 & 7.52 \\
\hline $\mathrm{NiO}$ & 0.05 & 0.07 & - & - & - & - \\
\hline $\mathrm{MnO}$ & 0.05 & 0.21 & 0.32 & 0.28 & 0.18 & 0.15 \\
\hline $\mathrm{MgO}$ & 16.82 & 14.2 & 13.56 & 13.4 & 13.0 & 5.44 \\
\hline $\mathrm{CaO}$ & 2.18 & 7.19 & 6.45 & 6.29 & 6.95 & 11.56 \\
\hline $\mathrm{Na}_{2} \mathrm{O}$ & 0.14 & 0.71 & 1.45 & 1.57 & 1.14 & 2.64 \\
\hline $\mathrm{K}_{2} \mathrm{O}$ & 0.04 & 0.91 & 0.59 & 0.35 & 0.79 & 0.14 \\
\hline Total & 88.9 & 92.7 & 90.94 & 91.55 & 90.87 & 93.74 \\
\hline $\mathrm{Mg} \#$ & 63 & 63 & 63 & 63 & 61 & 56 \\
\hline
\end{tabular}

a Approximate composition of groundmass exclusive of megacrysts, made by systematically moving the sample beneath rastered electron beam. 


\begin{tabular}{|c|c|c|c|c|c|c|c|c|c|c|}
\hline \multirow[b]{2}{*}{$\mathrm{SiO}_{2}$} & \multicolumn{4}{|c|}{$\begin{array}{l}\text { 756D-7R-3, } 50-54 \mathrm{~cm} \\
\text { (green-black Fe-rich saponite from blue-green zone) }\end{array}$} & \multicolumn{4}{|c|}{$\begin{array}{l}\text { 756D-7R-3, } 50-54 \mathrm{~cm} \\
\text { (saponite-glauconite from brown zone) }\end{array}$} & \multirow{2}{*}{$\begin{array}{c}\begin{array}{c}757 \mathrm{C}-12 \mathrm{R}-2, \\
0-5 \mathrm{~cm} \\
\text { (celadonite in } \\
\text { amygdule) }\end{array} \\
49.3\end{array}$} & \multirow{2}{*}{$\begin{array}{c}\begin{array}{c}758 \mathrm{~A}-61 \mathrm{R}-5 \\
22-26 \mathrm{~cm} \\
\text { (Fe-rich } \\
\text { saponite) }\end{array} \\
43.6\end{array}$} \\
\hline & 40.2 & 38.3 & 39.1 & 35.9 & 39.9 & 39.5 & 39.5 & 38.6 & & \\
\hline $\mathrm{TiO}_{2}$ & - & - & - & 0.03 & - & 0.11 & 0.29 & 0.16 & - & 0.09 \\
\hline $\mathrm{Al}_{2} \mathrm{O}_{3}$ & 6.47 & 5.93 & 5.65 & 6.70 & 8.2 & 7.52 & 6.94 & 7.58 & 4.6 & 4.70 \\
\hline $\mathrm{Cr}_{2} \mathrm{O}_{3}$ & - & - & - & - & - & - & - & - & - & - \\
\hline $\mathrm{FeO}$ & 18.4 & 18.1 & 18.1 & 18.8 & 20.4 & 19.5 & 18.2 & 17.9 & 16.7 & 18.2 \\
\hline $\mathrm{MnO}$ & - & - & 0.08 & 0.2 & - & 0.16 & 0.11 & 0.13 & - & 0.06 \\
\hline $\mathrm{MgO}$ & 13.0 & 12.1 & 13.3 & 12.5 & 13.0 & 12.4 & 12.1 & 12.5 & 6.70 & 15.0 \\
\hline $\mathrm{CaO}$ & 0.06 & 0.15 & 0.13 & 0.17 & - & 0.29 & 0.21 & 0.24 & 0.53 & 1.29 \\
\hline $\mathrm{Na}_{2} \mathrm{O}$ & 1.80 & 2.14 & 2.31 & 2.11 & 0.99 & 0.94 & 0.95 & 1.21 & 0.22 & 0.97 \\
\hline $\mathrm{K}_{2} \mathrm{O}$ & 0.27 & 0.13 & 0.17 & 0.18 & 2.81 & 2.89 & 3.23 & 2.56 & 7.15 & 0.46 \\
\hline Total & 80.13 & 76.9 & 78.81 & 76.55 & 85.3 & 83.3 & 81.43 & 80.86 & 85.16 & 84.37 \\
\hline Cations per 220 & 14.8 & 14.9 & 14.99 & 15.12 & 15.1 & 15.08 & 15.0 & 15.0 & 13.58 & 14.66 \\
\hline $\mathrm{Mg \#}$ & 55.6 & 54.3 & 56.9 & 54.1 & 53.3 & 53.2 & 54.2 & 55.6 & 41.7 & 51.7 \\
\hline \multicolumn{11}{|c|}{ Numbers of cations on basis of 220} \\
\hline $\mathrm{Si}$ & 6.88 & 6.87 & 6.55 & 6.55 & 6.57 & 6.66 & 6.77 & 6.65 & 7.97 & 7.06 \\
\hline Al & 1.12 & 1.13 & 1.45 & 1.44 & 1.43 & 1.34 & 1.23 & 1.35 & 0.03 & 0.90 \\
\hline Sum tetrahedral & 8.00 & 8.00 & 8.00 & 7.99 & 8.00 & 8.00 & 8.00 & 8.00 & 8.00 & 8.00 \\
\hline $\mathrm{Al}$ & 0.18 & 0.12 & 0.11 & - & 0.16 & 0.15 & 0.17 & 0.19 & 0.85 & - \\
\hline $\mathrm{Ti}$ & - & - & - & - & - & 0.01 & 0.04 & 0.02 & - & 0.01 \\
\hline $\mathrm{Fe}^{*}$ & 2.63 & 2.72 & 2.66 & 2.88 & 2.81 & 2.74 & 2.61 & 2.57 & 2.25 & 2.46 \\
\hline Mn & - & - & 0.01 & 0.03 & - & 0.02 & 0.02 & 0.02 & - & 0.01 \\
\hline $\mathrm{Mg}$ & 3.19 & 3.16 & 3.22 & 3.12 & 3.03 & 3.08 & 3.09 & 3.20 & 1.01 & 3.52 \\
\hline Sum octahedral & 6.00 & 6.00 & 6.00 & 6.00 & 6.00 & 6.00 & 5.93 & 6.00 & 4.11 & 6.00 \\
\hline $\mathrm{Ca}$ & 0.01 & 0.03 & 0.02 & 0.03 & - & 0.05 & 0.04 & 0.04 & 0.09 & 0.23 \\
\hline $\mathrm{Mg}$ & 0.11 & 0.08 & 0.25 & 0.27 & 0.17 & 0.04 & - & 0.02 & - & 0.10 \\
\hline $\mathrm{Na}$ & 0.60 & 0.75 & 0.79 & 0.75 & 0.32 & 0.31 & 0.32 & 0.40 & 0.07 & 0.30 \\
\hline K & 0.06 & 0.03 & 0.04 & 0.04 & 0.59 & 0.62 & 0.71 & 0.56 & 1.47 & 0.09 \\
\hline Interlayer charge & 0.90 & 0.98 & 1.37 & 1.37 & 1.25 & 1.11 & 1.07 & 1.08 & - & 1.05 \\
\hline Sum interlayered & & & & & & & & & 1.63 & \\
\hline $\mathrm{Si} / \mathrm{Al}$ & & & & & & & & & 9.1 & \\
\hline
\end{tabular}

\section{Sulfides}

\begin{tabular}{|c|c|c|c|c|c|c|}
\hline & $\begin{array}{l}758 \mathrm{~A}-56 \mathrm{R}-1 \text {, } \\
64-68 \mathrm{~cm} \\
\text { (chalcopyrite, } \\
20 \mu \mathrm{m} \text {, with } \\
\text { dissolved Co } \\
\text { and } \mathrm{Ni} \text { ) }\end{array}$ & $\begin{array}{c}758 \mathrm{~A}-59 \mathrm{R}-2 \text {, } \\
58-62 \mathrm{~cm} \\
\text { (chalcopyrite, } \\
\text { skeletal } \\
50-\mu \mathrm{m} \text { grain, } \\
\text { with Co and } \\
\mathrm{Ni} \text { ) }\end{array}$ & $\begin{array}{l}\text { 758A-59R-2, } \\
58-62 \mathrm{~cm} \\
\text { (small } \\
\text { corroded } \\
\text { grain, a } \\
\text { mixture of } \\
\mathrm{Cu}, \mathrm{Fe}, \mathrm{Co} \text {, } \\
\mathrm{Ni} \text { sulfides) }\end{array}$ & $\begin{array}{c}758 \mathrm{~A}-59 \mathrm{R}-2, \\
58-62 \mathrm{~cm} \\
\text { (equant } \\
\text { chalcopyrite } \\
\text { grain, } \\
\text { contains } \\
\text { very little } \\
\text { Co or } \mathrm{Ni} \text { ) }\end{array}$ & $\begin{array}{c}758 \mathrm{~A}-59 \mathrm{R}-2 \text {, } \\
58-62 \mathrm{~cm} \\
\text { (chalcopyrite } \\
\text { grain, } 20 \\
\mu \mathrm{m} \text {, with } \\
\text { low Co and } \\
\mathrm{Ni})\end{array}$ & $\begin{array}{c}758 \mathrm{~A}-73 \mathrm{R}-4, \\
105-109 \mathrm{~cm} \\
\text { (large pyrite } \\
\text { grain) }\end{array}$ \\
\hline $\mathrm{Fe}$ & 28.3 & 25.9 & & 32.4 & 32.5 & 48.9 \\
\hline Co & 2.14 & 3.77 & & 0.04 & 0.1 & 0.02 \\
\hline $\mathrm{Ni}$ & 1.87 & 3.19 & & - & 0.18 & - \\
\hline $\mathrm{Cu}$ & 29.0 & 25.6 & & 30.3 & 33.9 & - \\
\hline $\mathrm{Zn}$ & 0.02 & 0.02 & & 0.03 & 0.1 & - \\
\hline$S$ & 29.8 & 29.9 & & 31.3 & 33.2 & 50.6 \\
\hline Total & 91.23 & 88.45 & $\mathrm{~b}_{(82.01)}$ & 94.14 & 99.97 & 99.5 \\
\hline \multicolumn{7}{|c|}{ Atomic proportions } \\
\hline $\mathrm{Fe}$ & 0.25 & 0.242 & 0.149 & 0.285 & 0.27 & 0.357 \\
\hline Co & 0.019 & 0.033 & 0.12 & 0.000 & 0.000 & 0.000 \\
\hline $\mathrm{Ni}$ & 0.016 & 0.02 & 0.129 & - & 0.000 & - \\
\hline $\mathrm{Cu}$ & 0.233 & 0.21 & 0.093 & 0.234 & 0.247 & - \\
\hline $\mathrm{Zn}$ & 0.000 & 0.000 & 0.000 & 0.000 & 0.000 & - \\
\hline $\mathrm{S}$ & 0.474 & 0.486 & 0.509 & 0.48 & 0.48 & 0.643 \\
\hline Sum & 1.00 & 1.0 & 1.0 & 1.0 & 1.0 & 1.0 \\
\hline
\end{tabular}

${ }^{b}$ Low total is probably a result of alteration. 